
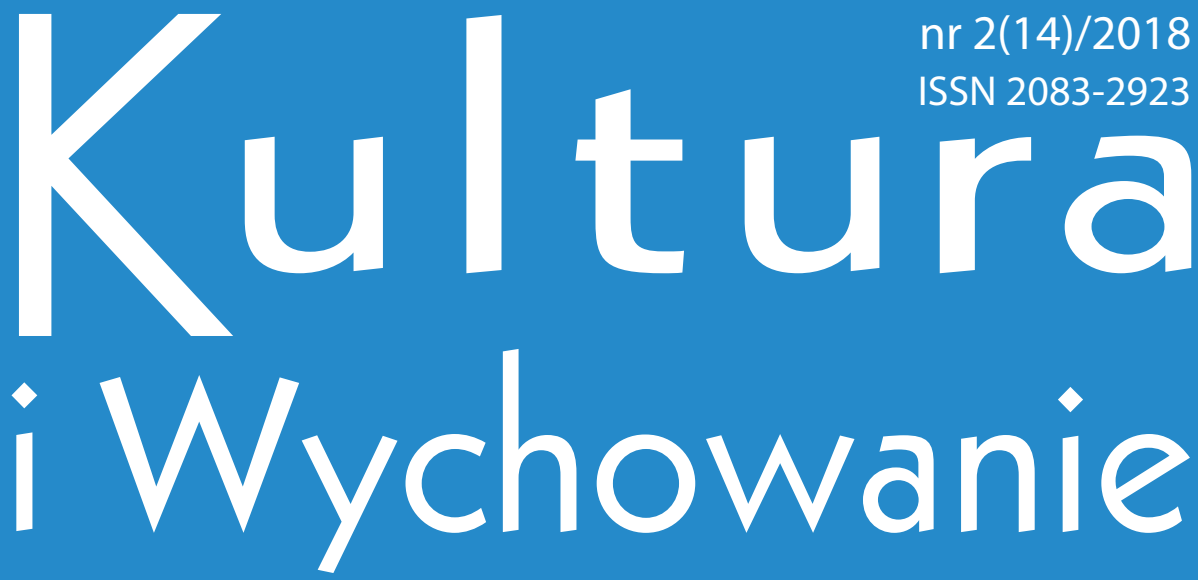

Półrocznik pedagogiczny

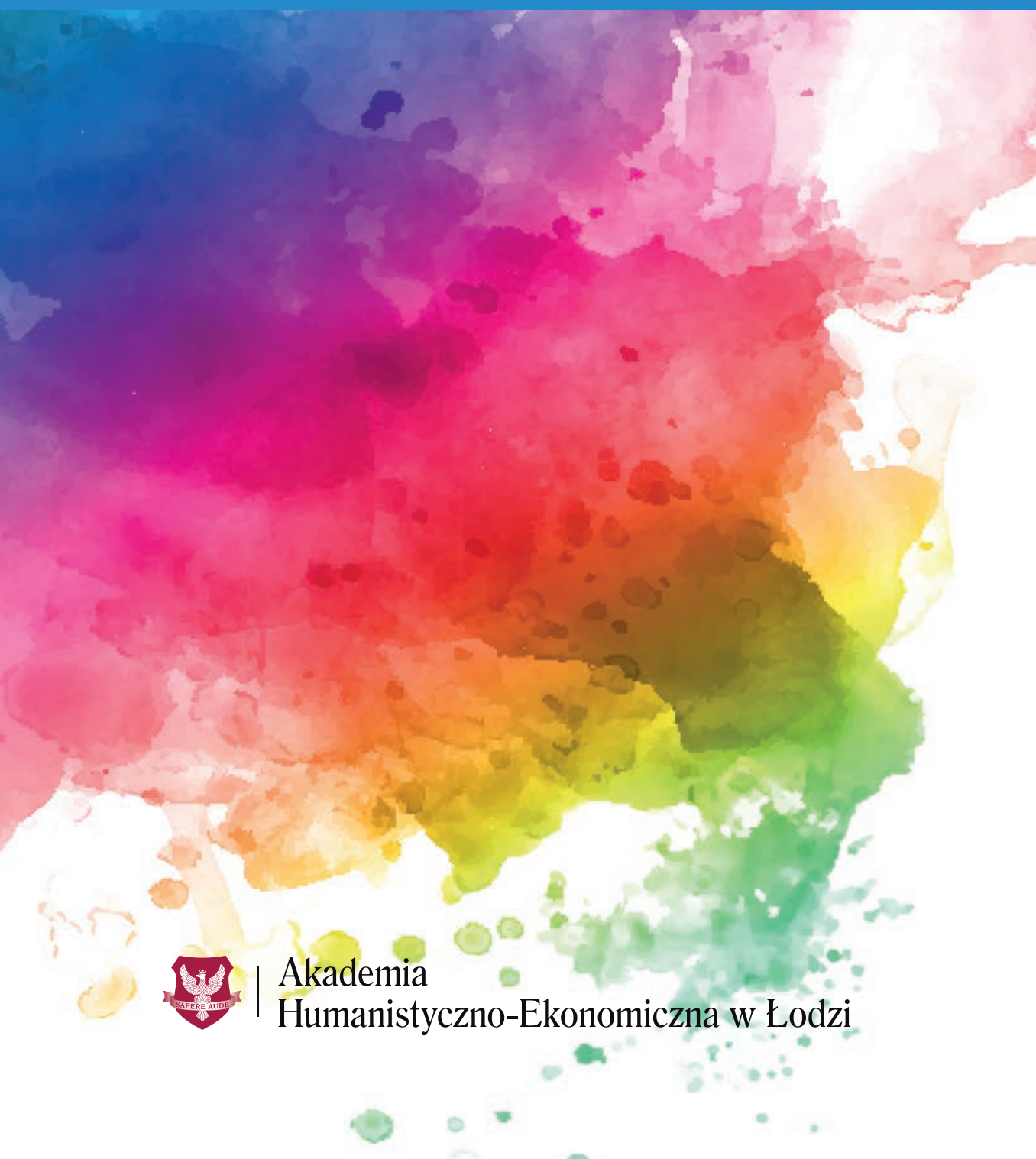



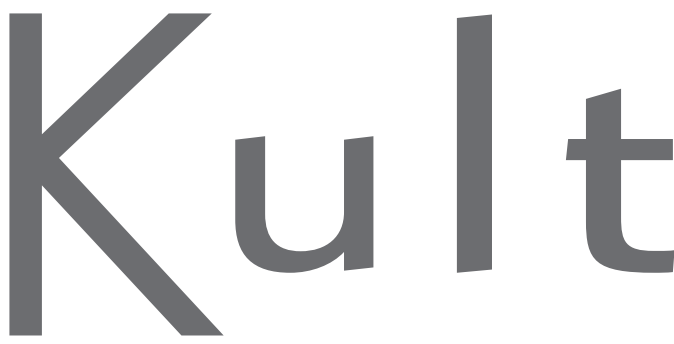

$\mathrm{nr} 2(14) / 2018$

ISSN E-WYDANIE 2083-2923
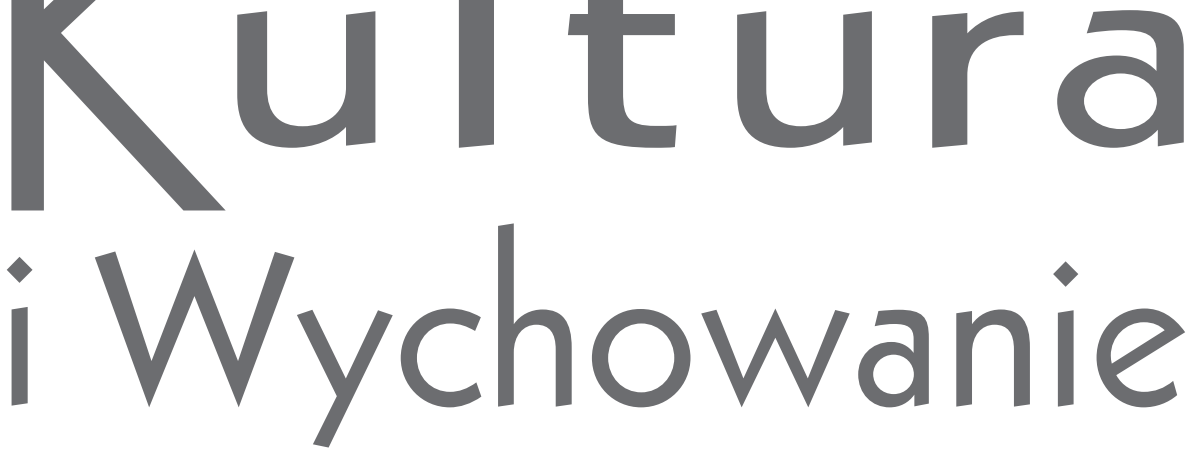

Półrocznik pedagogiczny 
REDAKCJA CZASOPISMA

Redaktor naczelny: dr Krzysztof Kamiński

Z-ca redaktora naczelnego: dr Elżbieta Woźnicka

\section{RADA NAUKOWA}

\section{Przewodnicząca rady naukowej}

dr hab. Zofia Szarota, prof. UP, Uniwersytet Pedagogiczny im. KEN w Krakowie

\section{Polska rada naukowa}

prof. dr hab. Irena Adamek, Akademia Techniczno-Humanistyczna w Bielsku-Białej prof. dr hab. Edyta Gruszczyk-Kolczyńska, Akademia Pedagogiki Specjalnej im. Marii Grzegorzewskiej w Warszawie prof. dr hab. Bożena Muchacka, Uniwersytet Pedagogiczny im. KEN w Krakowie prof. dr hab. Maria Szyszkowska, Uniwersytet Warszawski, Komitet Prognoz „Polska 2000 Plus” przy Prezydium PAN prof. dr hab. Stanisław Gałkowski, Akademia Ignatianum w Krakowie dr hab. Rafał Godoń, Uniwersytet Warszawski prof. dr hab. Krzysztof Jakubiak, Uniwersytet Gdański prof. dr hab. Lech Mokrzecki, emerytowany prof. UG, Uniwersytet Gdański prof. dr hab. Stanisław Palka, Uniwersytet Jagielloński w Krakowie dr hab. Dariusz Stępkowski, prof. UKSW, Uniwersytet Kardynała Stefana Wyszyńskiego w Warszawie prof. dr hab. Bogdan Szczepankowski, Społeczna Akademia Nauk w Warszawie dr hab. Sławomir Szczyrba, Uniwersytet Kardynała Stefana Wyszyńskiego w Warszawie (WSD w Łodzi)

dr hab. Sławomir Sztobryn, prof. ATH, Akademia Techniczno-Humanistyczna w Bielsku-Białej

\section{Międzynarodowa rada naukowa}

prof. dr hab. Blanka Kudláčová, Uniwersytet w Trnavski w Trnavie, Słowacja prof. dr hab. Naděžda Pelcová, Uniwersytet Karola w Pradze, Czechy prof. dr hab. Irina Predborska, Towarzystwo Filozofii Edukacji, Ukraina prof. dr hab. Ałła Wasyluk, Narodowa Akademia Nauk Pedagogicznych Ukrainy, Ukraina prof. dr hab. Dietrich Benner, Uniwersytet Berliński, Niemcy prof. dr hab. Rudolf Dupkala, Uniwersytet Preszowski w Preszowie, Słowacja 
RECENZENCI „Kultura i Wychowanie” nr 2(14)/2018

dr hab. Jakub Bartoszewski, prof. PWSZ, Państwowa Wyższa Szkoła Zawodowa w Koninie dr hab. Jan Chodkiewicz, prof. UŁ, Uniwersytet Łódzki

dr hab. Katarzyna Dormus, prof. UP, Uniwersytet Pedagogiczny w Krakowie

prof. dr hab. Eugeniusz Józefowski, Akademia Sztuk Pięknych im. Eugeniusza Gepperta we Wrocławiu

dr hab. Beata Gofron, Szkoła Główna Gospodarstwa Wiejskiego w Warszawie

dr Anna Gutowska, Uniwersytet Łódzki

prof. dr hab. Wiesław Karolak, Akademia Humanistyczno-Ekonomiczna w Łodzi

dr hab. Jacek Kurzępa, prof. AHE, Akademia Humanistyczno-Ekonomiczna w Łodzi

dr Aleksandra Litawa, Uniwersytet Pedagogiczny w Krakowie

dr hab. Kinga Łapot-Dzierwa, prof. UP, Uniwersytet Pedagogiczny w Krakowie

dr hab. Helena Marzec, prof. AHE, Akademia Humanistyczno-Ekonomiczna w Łodzi

dr hab. Irena Motow, Uniwersytet Humanistyczno-Przyrodniczy im. Jana Długosza w Częstochowie

dr hab. Katarzyna Plutecka, prof. UP, Uniwersytet Pedagogiczny w Krakowie

dr hab. Dorota Podgórska-Jachnik, prof. UKW, Uniwersytet Kazimierza Wielkiego w Bydgoszczy

dr hab., Dariusz Stępkowski, prof. UKSW, Uniwersytet Kardynała Stefana Wyszyńskiego w Warszawie

dr Nella Stolińska-Pobralska, Uniwersytet Łódzki

dr hab. Renata Szczepanik, prof. UŁ, Uniwersytet Łódzki

dr hab. Sławomir Sztobryn, prof. ATH, Akademia Techniczno-Humanistyczna w Bielsku-Białej

Adres redakcji czasopisma „Kultura i Wychowanie”

Akademia Humanistyczno-Ekonomiczna w Łodzi

90-212 Łódź, ul. Sterlinga 26, pok. K 108

e-mail: kulturaiwychowanie@ahe.lodz.pl

strona www: www.pedagogika.pl

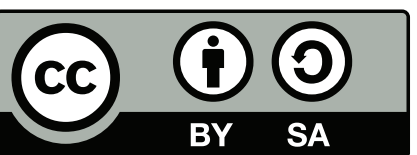

Ten utwór jest dostępny na licencji Creative Commons Uznanie autorstwa-Na tych samych warunkach 4.0 Międzynarodowe. 
(C) Copyright by Akademia Humanistyczno-Ekonomiczna w Łodzi Łódź 2018

ISSN 2083-2923

Wersją podstawową jest wersja elektroniczna

Projekt graficzny okładki

Joanna Niekraszewicz

Redaktor prowadzący

Iwona Morawska

Redakcja językowa i korekta

Renata Frątczak

Opracowanie typograficzne i skład DTP

Monika Poradecka

\section{Wydawnictwo}

Akademii Humanistyczno-Ekonomicznej w Lodzi

90-212 Łódź, ul. Sterlinga 26

tel. 426315908

wydawnictwo@ahe.lodz.pl

www.wydawnictwo.ahe.lodz.pl 


\section{Spis treści}

\section{ROZPRAWY FILOZOFICZNO-HISTORYCZNE}

\section{Aneta Stawiszyńska}

Działalność Związku Młodzieży Polskiej Pochodzenia Żydowskiego

„Żagiew” w Kodzi w latach I wojny światowej (1914-1918)

Andrej Rajský

Ad unum vertere? Education as con-versio from multitude

\section{ROZPRAWY TEORETYCZNO-EMPIRYCZNE}

Karolina Skarbek

Trudne zachowania u dzieci w wieku przedszkolnym -

nieprawidłowości w rozwoju psychoruchowym czy błędy

w procesie wychowawczym?

Karolina Ruta-Korytowska, Marta Wrześniewska-Pietrzak

Obraz szkoły i edukacji uczniów głuchych w Polsce

w wypowiedziach dorosłych osób niesłyszących

Monika Banaszczyk

Pedagogika wobec schizofrenii

Agnieszka Deja

Porozumiewanie się pracowników z podopiecznymi jako proces

budowania i podtrzymywania relacji w rodzinnym domu dziecka

Karolina Kołodziejczak, Katarzyna Smoter

Portret polskich millenialsów w twórczości muzycznej

Taco Hemingwaya 
Magdalena Sasin

Kanon wykonawczy muzyki poważnej jako przestrzeń

spotkania Innego

Karolina Prymas-Jóźwiak

Komfort wyboru czy wybór komfortu? O strategiach

edukacyjnych w szkole artystycznej (na przykładzie

własnych doświadczeń nauczycielskich)

Kinga Konieczny

Formy wsparcia rodziny w ramach projektów unijnych.

Praca systemowa z rodziną w opinii specjalistów

Katarzyna Okólska

Uwarunkowania procesu zmagania się z uzależnieniem od alkoholu.

Studium przypadku

Agnieszka Hamerlińska, Emilia Kotlęga, Agnieszka Kamyk-Wawryszuk

Karmienie piersią dziecka w miejscach publicznych a postawy

kobiet i mężczyzn - komunikat z badań

\section{SPRAWOZDANIA I RECENZJE}

Jasmina Al-Douri

Pomiędzy rzeczywistością a mitologizacja. Recenzja książki

Małgorzaty Stępnik, Outsiderzy, mistyfikatorzy, eskapiści

w sztuce XX wieku. Studium postaw twórczych, WUMCS, Lublin $2016 . .$.

Krzysztof Kamiński

Sprawozdanie z konferencji „Miłość w pedagogice -

pedagogika w akcie twórczym"

\section{STUDENCI PISZA}

Adriana Modrzejewska, Julia Nowak, Radosław Pujanek

Aspekt wychowawczy kluczowych teorii psychologicznych

w kontekście prewencji dziecięcych zachowań niepożądanych 


\section{Contents}

\section{PHILOSOPHICAL AND HISTORICAL DISSERTATIONS}

\section{Aneta Stawiszyńska}

The activity of the Association of Polish Youth

of Jewish Origin "Żagiew” in Kódź during the First World War

(1914-1918)

Andrej Rajský

Ad unum vertere? Education as con-versio from multitude

\section{THEORETICAL AND EMPIRICAL DISSERTATIONS}

Karolina Skarbek

Difficult behaviours in preschool-aged children - abnormalities in

psychomotor development or mistakes in the upbringing process? .....

Karolina Ruta-Korytowska, Marta Wrześniewska-Pietrzak

A picture of school and the education of deaf students in Poland

derived from texts written by deaf adultsh

Monika Banaszczyk

Pedagogy in the face of schizophrenia

Agnieszka Deja

The communication between staff and children as a process in

building and maintaining relationships in the family foster home

Karolina Kołodziejczak, Katarzyna Smoter

A Portrait of Polish Millennials in the songs of Taco Hemingway. 
Magdalena Sasin

The Western canon in classical music as a space of meeting

with The Other

Karolina Prymas-Jóźwiak

The comfort of choice or the choice of comfort?

On educational strategies in a school of fine arts

(based on the author's own teaching experiences)

Kinga Konieczny

Forms of family support as part of EU projects. Systemic work

with families according to the opinion of specialists

Katarzyna Okólska

Conditions conducive to the self-treatment of a person addicted

to alcohol. A case study

Agnieszka Hamerlińska, Emilia Kotlęga, Agnieszka Kamyk-Wawryszuk

Breastfeeding in public places. Attitudes of women and men

\section{REPORTS AND REVIEWS}

Jasmina Al-Douri

Between reality and mythologisation. Book review of Małgorzata

Stępnik, Outsiders, mystifiers, escapists in $20^{\text {th }}$ century art. A study

of creative attitudes, WUMCS, Lublin 2016

Krzysztof Kamiński

A report from the conference „Love in pedagogy -

pedagogy in a creative act"

\section{STUDENTS WRITE}

Adriana Modrzejewska, Julia Nowak, Radosław Pujanek

Educational aspect of the key psychological theories in relation to prevention of child adverse behaviour. 


\title{
Działalność Związku Młodzieży Polskiej Pochodzenia Żydowskiego "Żagiew" w Łodzi w latach I wojny światowej (1914-1918)
}

\begin{abstract}
Streszczenie: Przez kilka lat na terenie Łodzi działał Związek Młodzieży Polskiego Pochodzenia Żydowskiego „Żagiew”, skupiający młodzież żydowską. Organizacja reprezentowała kierunek asymilatorski. W czasie Wielkiej Wojny członkowie organizacji aktywnie angażowali się w działania związane z kwestią polską, na przykład w obchody rocznic polskich. „Żagiew”, zarówno w czasie wojny, jak i po jej zakończeniu, widziała rozwiązanie kwestii żydowskiej w niepodległym państwie polskim, a także dyskutowali z organizacjami syjonistycznymi, które dążyły do osiedlenia się mniejszości żydowskiej poza Polską. Organizacja „Żagwi” w Łodzi nie miała jednak zbyt dużego wpływu na żydowskie środowisko młodzieżowe.
\end{abstract}

Słowa kluczowe: Łódź 1914-1918, Związek Młodzieży Polskiej Pochodzenia Żydowskiego „Żagiew”, Żydzi w Łodzi

Lata okupacji niemieckiej w czasie I wojny światowej stanowiły jedną z najtragiczniejszych kart w dziejach Łodzi. Okupant niemiecki dążył do unicestwienia miejscowego przemysłu, a skutkiem tego była bieda o niespotykanych wcześniej rozmiarach. W tym samym czasie nastąpiły jednak zmiany o charakterze pozytywnym. Liberalniejsza $\mathrm{w}$ porównaniu z czasami zaborów polityka społeczna pozwalała na

\footnotetext{
Aneta Stawiszyńska (ur. 1983) - dr nauk humanistycznych; rozprawa doktorska napisana w Katedrze Historii Polski Najnowszej IH UŁ - Łódź w latach I wojny światowej. Zainteresowania badawcze: dzieje społeczne I wojny światowej, dzieje regionu łódzkiego. Publikacje: ok. 80 artykułów naukowych i popularnonaukowych poświęconych głównie dziejom Łodzi i regionu oraz dwie książki: Ruda Pabianicka. Echa przeszłości (2009) i Łódź w latach I wojny światowej (2016).
} 
rozwój organizacji społecznych ${ }^{1}$. Z możliwości powoływania do życia nowych stowarzyszeń korzystała także młodzież, która coraz chętniej grupowała się w różnych organizacjach, zwłaszcza harcerskich, których działalność była zakazana przez władze carskie ${ }^{2}$. Jednym ze stowarzyszeń młodzieżowych powstałych w latach I wojny światowej był Związek Młodzieży Polskiej Pochodzenia Żydowskiego „Żagiew”. Na wstępie zaznaczyć należy, że pełna charakterystyka działalności wspomnianej organizacji na gruncie łódzkim jest trudna ze względu na brak zachowanych źródeł. „Żagiew” nie pozostawiła po sobie zwartej bazy archiwalnej, stąd niemożliwe jest podanie choćby liczby jej członków. Jedynymi materiałami pozwalającymi na określenie charakteru organizacji są wydawane przez nią ulotki zachowane w zbiorach Archiwum Państwowego w Łodzi, a także nieliczne informacje prasowe.

Związek Młodzieży Polskiej Pochodzenia Żydowskiego „Żagiew” został założony w Warszawie pod koniec 1915 r. przez zwolenników asymilacji ludności żydowskiej z narodem polskim. Początkowo organizacja działała nielegalnie, przez co jej funkcjonowanie było znacznie utrudnione. Pierwotnym celem powołania organizacji była działalność dobroczynna. Szybko jednak pojawiły się hasła walki z agitacją „nacjonalistyczno-syjonistyczną”, a przy Związku powołano wówczas Sekcję Asymilacyjną. W czerwcu 1916 r. wyszła deklaracja „Żagwi”. Postulowano w niej zachowanie odrębności religijnej, a za cel stawiano sobie zapoznanie społeczeństwa polskiego z problemami ludności żydowskiej zamieszkującej na ziemiach polskich. Wszelkie kwestie problematyczne z tym związane miały być rozwiązane przez przyszłe niepodległe państwo polskie, a kwestia żydowska uznawana była przez organizację za wewnętrzną sprawę państwa ${ }^{4}$. W kwestiach ustrojowych opowiadano się za monarchią konstytucyjną ${ }^{5}$. Sama „Żagiew” stawiała sobie też za cel wychowanie młodzieży żydowskiej na polskich patriotów - swoich zwolenników nawoływała m.in. do wstępowania do Legionów Polskich. Jednocześnie podejmowano walkę z innymi organizacjami, jak

${ }^{1}$ Szerzej: A. Stawiszyńska, Łódź w latach I wojny światowej, Napoleon V, Oświęcim 2016, s. $75-220$.

${ }^{2}$ K. Jurek, Lilijka i łódka. Historia harcerstwa polskiego do 1939 roku, Wydawnictwo Księży Młyn, Łódź 2006, s. 12-17.

3 „Żagiew”, IV 1919, nr 1-2, s. 11-12.

${ }^{4} \mathrm{Na}$ łamach „Żagwi” czytamy: „Ów wrzód ropiący [nierozwiązana sprawa żydowska - AS] i bolesny, który jątrzy się, a który rozgrzebywany przez obce ręce nie zdoła się nawet zabliźnić. Społeczeństwo polskie nie miało nigdy możności jasnego i spokojnego rozważania. Kwestia żydowska była kwestią sklepików z wiktuałami lub łokciowemi towarami, była kwestią egzystencji poszczególnych rodzin, kwestia walki o byt [...]”, „Żagiew”, 15 XII 1916, nr 6, s. 1-2.

5 J. Lichten, Uwagi o asymilacji i akulturacji Żydów w Polsce w latach 1863-1943, „Znak”, R. XL, z. 5-6/1988, s. 60-62. 
Markez czy Ha-Szomer ${ }^{6}$ o typowo syjonistycznym charakterze ${ }^{7}$. Organizacja „Żagiew” posiadała typowo niepodległościowy charakter. Poza Warszawą, działała najprężniej w Łodzi ${ }^{8}$.

Na gruncie łódzkim na czele organizacji „Żagiew” stał Konrad Urbach . Początek działalności stowarzyszenia miał miejsce w styczniu 1916 r. Siedziba Związku mieściła się przy ul. Szkolnej 24 (obecnie Mielczarskiego) ${ }^{10}$. Drużyny podlegały własnej Komendzie Głównej ${ }^{11}$.

Organizacja wydawała w Warszawie w latach 1916-1920 oraz 1926-1927 pismo „Żagiew”, redagowane przez Stefana Lublinera i Jana Ruffa. Pierwszy numer pisma ukazał się we wrześniu 1916 r. i był wydrukowany na specjalnym powielaczu metodą hektograficzną ${ }^{12}$. Wśród autorów artykułów byli m.in. Kazimierz Sterling (ps. Woj-

${ }^{6} \mathrm{Ha}$-Szomer - były to żydowskie grupy skautowe powstające głównie w Królestwie Polskim oraz w Galicji przed I wojną światową; nazwa pochodziła od organizacji Ha-Szomer powstałej w 1909 r. w Erec Israel w celu chronienia osadników żydowskich przed napadami arabów; Ha-Szomer pozostawała pod silnym naciskiem wzorców skautingu europejskiego, w tym polskiego, przenikłych duchem niepodległościowym; na członków miał wpływ niemiecki ruch młodzieżowy - Wandervogel - który sprzeciwiał się militaryzmowi oraz dyscyplinie w szkole i rodzinie, ograniczający niezależność młodego pokolenia; w 1916 r. doszło w Wiedniu do połączenia Ha-Szomeri Ceirej-Syjon, a w 1917 r. odbył się w Częstochowie zjazd założycielski nowejorganizacji Ha-Szomer ha-Cair w Polsce; organizacja stawiała sobie za zadanie przygotowanie młodzieży do emigracji i pracy w Palestynie; w połowie lat 20. XX w. organizacja zbliżyła się do Poalej Syjon-Prawica; członkowie nosili miano szomrów, podstawową jednostką był keruzach (zastęp); młodzież zgrupowana była na 3 poziomach według wieku 11-14 fefrim (szczenięta), 15-16 benei midbar (synowie pustyni) i młodzież powyżej 17 lat bogerim (dojrzali) będący kadrą instruktorską; lokalne oddziały nosiły nazwę Ken (gniazdo); R. Żebrowski, Ha-Szomer, [w:] Polski słownik judaistyczny: dzieje kultura - religia - ludzie, t. 1, opr. Z. Borzymińska i R. Żebrowski, Wydawnictwo Prószyński i S-ka, Warszawa 2003, s. 566; T. Guzik, M. Skoczeń, Żydowskie organizacje skautowe w Polsce w latach 1916-1945, „Harcerstwo”, R. XXXII, nr 1/1990, s. 38-39; Kozłowski Cz. (red.), Słownik organizacji młodzieżowych w Polsce 1918-1970, Iskry, Warszawa 1971, s. 25; Tomaszewski J., A. Żbikowski (red.), Żydzi w Polsce. Dzieje i kultura. Leksykon, Wydawnictwo Cyklady, Warszawa 2001, s. 128.

${ }^{7}$ K. Jurek, Organizacja skautowa młodzieży żydowskiej „Harcerz Polski”. Przyczynek do problematyki mniejszości narodowych w ZHP, „Harcerstwo”, R. XXVIII, nr 6/1986, s. 34-35.

${ }^{8}$ M. Kałuski, W podzięce i ku pamięci Jankielom, Warszawa 2001, s. 26.

${ }^{9}$ Najprawdopodobniej: Jan Urbach (1895-1987) - członek Legionów Polskich; przyjął imię Konrad dla podkreślenia idei romantycznych, odznaczony krzyżem niepodległości; dziennikarz; redaktor „Głosu Porannego”; współpracował z „Głosem Polski” i „Republiką”; autor książki Udział Żydów w walce o niepodległość Polski; sprawozdawca sejmowy, ojciec Jerzego Urbana; A. Bojarska, Urban, Krajowa Agencja Promocyjna, Gdańsk 2000, s. 13-14; W. Kaszubina, Notatki o prasie łódzkiej, „Rocznik Historii Czasopiśmiennictwa Polskiego”, nr 7/1/1968, s. 178; M. Starzycka, Przetrwali na Piotrkowskiej. Mała łódzka historia, „Kronika Miasta Łodzi”, nr 1-2/2015, s. 115; R. Urbaniak, Z dziejów prasy łódzkiej - „Republika” 1923-1925, „Acta Universitatis Lodziensis. Folia Historica” 2008, t. 82, s. 60; B. Wachowska, Tradycje powstania listopadowego (1880-1942), „Acta Universitatis Lodziensis. Folia Historica", t. 16/1983, s. 57-58.

10 Informator miasta Łodzi z kalendarzem na rok 1919, Łódź 1918, s. 235.

${ }_{11}$ R. Żebrowski, Żagiew, [w:] Polski słownik judaistyczny: dzieje - kultura - religia - ludzie, t. 2, dz. cyt., s. 348 .

12 „Żagiew”, nr 1-2/1919, s. 23. 
ciech Kessling) i Jan Rybałt. Podobnie jak organizacja, głosiło ono idee krzewienia patriotycznych tradycji wśród Żydów polskich i nawoływało, zwłaszcza najmłodsze pokolenie, do asymilacji z narodem polskim ${ }^{13}$. Niekiedy na łamach pisma pojawiały się wiersze o charakterze patriotycznym, nawiązujące zwykle do wielkich wydarzeń z historii Polski. W tekstach poświęconych sprawom bieżącym, ostrej krytyce poddawano przeciwników tj. ugrupowania syjonistyczne, a zwłaszcza osobę Noacha Pryłuckiego ${ }^{14}$. W 1919 r. redakcja pisma mieściła się w Warszawie przy Al. Jerozolimskich $51 \mathrm{~m}$. 20, a adres z czasów wojny nie był ujawniany ze względów bezpieczeństwa ${ }^{15}$. Treści publikowane na łamach czasopisma były cytowane przez inne periodyki kierowane do młodzieży żydowskiej ${ }^{16}$. Działacze łódzkiej „Żagwi” nie pisywali artykułów do wspomnianego pisma, przesyłali jednak wydawane przez siebie odezwy, a także sprawozdania z działalności.

Chętni do wstąpienia w szeregi organizacji zobowiązani byli do podpisania deklaracji, w której zobowiązywali się do pracy w jednej z dwóch Sekcji, tj. Nauczania lub Agitacyjnej, a także opłacania miesięcznej składki. Każdy z kandydatów musiał być zaakceptowany przez dwóch członków sprawdzających ${ }^{17}$. Przy organizacji oprócz wymienionych wcześniej sekcji istniała też Sekcja Statystyczna, odpowiedzialna za przeprowadzenie ankiet dotyczących zarówno funkcjonowania „Żagwi” w poszczególnych miejscowościach, jak i zbieraniem danych na temat innych grup żydowskich, głównie o charakterze syjonistycznym ${ }^{18}$.

Członkowie tej organizacji powołali we wrześniu 1916 r. do życia Wolne Drużyny Skautowe im. Berka Joselewicza. Po wydaniu Aktu 5 Listopada, zarząd organizacji

${ }^{13}$ M. Fuks, Prasa żydowska w Polsce w XIX i pierwszej połowie XX wieku (do końca II wojny światowej), „Roczniki Historii Czasopiśmiennictwa Polskiego”, nr 12/1973, s. 32; tenże, „Żagiew”. Pismo Młodzieży Polskiej Pochodzenia Żydowskiego, [w:] Polski słownik judaistyczny: dzieje - kultura - religia - ludzie, t. 2, dz. cyt., s. 839, 850.

${ }^{14}$ Noach Pryłucki (1882-1941/1942) - polityk, lider tzw. fołkistów, dziennikarz, poseł na sejmy (1919, 1922-1927), członek Rady Stanu, „Żagiew”, II 1917, nr 1-2, s. 8-9; Cz. Brzoza, Pryłucki Nojach. Kto był kim w Drugiej Rzeczypospolitej, red. nauk. J.M. Majchrowski przy współpracy G. Mazura i K. Stepana, BGW, Warszawa 1994, s. 404; J. Fałkowski, Mniejszość żydowska w parlamencie II Rzeczypospolitej (1922-1939), Kraków 2006; tegoż, Posłowie żydowscy w Sejmie Ustawodawczym 1919-1922, Oficyna Wydawnicza AFM, Częstochowa 2000; M. Fuks, Pryłucki (Pritucki) Noe (Noach, Nojach), Polski Słownik Biograficzny, t. XXVIII, Wrocław-Waszawa-Kraków-Gdańsk-Łódź 19841985, s. 629-630; Sz. Rudnicki, Żydzi w parlamencie II Rzeczypospolitej, Wydawnictwo Sejmowe, Warszawa 2015; A. Polonsky, Dzieje Żydów w Polsce i Rosji, Wydawnictwo Naukowe PWN, Warszawa 2014, s. 260, 263, 311, 348, 389.

15 „Żagiew”, IV 1919, nr 1-2, s. 1.

${ }^{16}$ S. Kwiecień, Kartka z dziejów prasy dla dzieci i młodzieży w okresie autonomii galicyjskiej, „Annales Universitatis Paedagogicae Cracoveinsis. Studia ad Bibliothecarum Scientiam Pertinentia”, t. XIII/2015, s. 153.

17 Archiwum Państwowe w Łodzi (dalej: APŁ), Zbiór Druków i Pism Ulotnych (dalej: ZDiPU), sygn. 235, k. 2, Deklaracja-formularz Związku Młodzieży Polskiej Pochodzenia Żydowskiego "Żagiew” $1917 \mathrm{r}$.

18 „Żagiew”, 15 XII 1916, nr 6, s. 6-7; „Żagiew”, II 1917, nr 1-2, s. 18. 
nawoływał do tworzenia kolejnych jednostek ${ }^{19}$. Już w styczniu 1917 r. działało pięć drużyn - w Warszawie, Łodzi, Tomaszowie, Kaliszu oraz Sosnowcu, które regularnie składały sprawozdania ze swojej działalności ${ }^{20}$. Na czele warszawskiego zarządu stał Bolesław Janusz Kachel, a następnie Leon Bergman. Drużyny dążyły do odciągnięcia młodzieży żydowskiej od ruchów antypolskich ${ }^{21}$. Pomimo starań ze strony organizacji by została ona włączona do Związku Harcerstwa Polskiego (ZHP), do połączenia nie doszło, gdyż jak argumentowali przywódcy ZHP, Drużyny zbyt mocno zaangażowane były w kwestie polityczne. Ostatecznie organizacja została zdelegalizowana przez Cesarsko-Niemieckie Prezydium Policji w Warszawie 28 września 1917 r. ${ }^{22}$

Brak stosownych źródeł nie pozwala na dokładną charakterystykę działalności podejmowanej przez członków „Żagwi”. Jednym z najważniejszych przejawów jej aktywności na terenie Łodzi było angażowanie się w obchody polskich świąt i rocznic narodowych. Uroczystości te były dla członków organizacji sposobnością do manifestowania stanowiska propolskiego ${ }^{23}$.

Tak stało się w 1917 r. podczas obchodów rocznicy uchwalenia Konstytucji 3 Maja. Jak relacjonowała to ówczesna prasa, organizacja prowadziła przy okazji opisywanej rocznicy energiczną akcję odczytową ${ }^{24}$, głównie na terenie Bałut, zamieszkałych przez dużą liczbę osób narodowości żydowskiej ${ }^{25}$. Podczas nabożeństwa w synagodze przy ul. Wolborskiej pełnili straż honorową ${ }^{26}$.

Wspomniane obchody stawały się niekiedy punktem zapalnym w stosunkach z innymi ugrupowaniami młodzieży żydowskiej, zwłaszcza z tymi o charakterze syjonistycznym ${ }^{27}$. Tak stało się podczas obchodów majowych w 1916 r., w których brali udział uczniowie miejscowych szkół średnich wyznania mojżeszowego ${ }^{28}$. Bezpo-

19 „Żagiew,” 21 XI 1916, nr 5, s. 3-4.

20 „Żagiew”, II 1917, nr 1-2, s. 5.

21 K. Jurek, Organizacja skautowa..., dz. cyt., s. 35.

22 „Żagiew”, 15 X 1917, nr 5-6, s. 2; L. Gorycki, Skauting mniejszości narodowych i etnicznych w II Rzeczypospolitej (cz. IV) - Drużyny Skautowe im. Berka Joselewicza, „Skaut”, R. XIII, nr 3/2017, s. 8-11; K. Jurek, Organizacja skautowa..., dz. cyt., s. 36; R. Żebrowski, Drużyny Harcerskie im. Berka Joselewicza, [w:] Polski słownik judaistyczny: dzieje - kultura - religia - ludzie, t. 1, dz. cyt., s. 171.

${ }^{23}$ Po latach zaborów, kiedy zakazane było obchodzenie wszelkich rocznic narodowych, w latach okupacji niemieckiej obchody te przyjmowały imponujące rozmiary, przyciągając rzesze łodzian. Szerzej na temat obchodów rocznicowych w Łodzi w latach Wielkiej Wojny: A. Stawiszyńska, Łódź w latach..., dz. cyt, s. 177-184.

24 „Gazeta Łódzka” (dalej: GŁ), 2 V 1917, nr 119, s. 3.

${ }^{25} \mathrm{GE}, 4 \mathrm{~V}$ 1917, nr 121, s. 3.

${ }^{26}$ GE, 2 V 1917, nr 119, s. 3.

27 Syjonizm - ruch społeczny i polityczny zapoczątkowany przez Teodora Hertzla pod koniec XIX wieku, dążący do budowy państwa żydowskiego na terenie Palestyny. Zwolennicy ruchu nawoływali do przesiedlania się ludności żydowskiej na te tereny, J. Pajewski, Historia powszechna 1871-1918, Państwowe Wydawnictwo Naukowe, Warszawa 1971, s. 69.

${ }^{28}$ Warto wspomnieć w tym miejscu, że istniał wówczas zwyczaj celebrowania rocznic narodowych w świątyniach wyznań, do których przynależeli uczniowie. Uczniowie ewangelicy modlili się w kaplicy szkolnej, podobnie jak ich katoliccy koledzy, lecz w różnych salach. Młodzież żydowska 
średnio po odśpiewaniu pieśni Boże coś Polskę, obecna na nabożeństwie młodzież z organizacji syjonistycznych, zaintonowała hymn Nadzieja ${ }^{29}$. Odśpiewanie tejże pieśni stało się przyczyną wywołania ogólnego zamieszania, gdyż obecni w synagodze uczniowie należący do „Żagwi” czy posiadających zbliżony do niej charakter Organizacji Drużyn Skautowych im. Tadeusza Kościuszki ${ }^{30}$, w odpowiedzi przystąpili do odśpiewania Roty. Wywołane zamieszanie przyczyniło się w ocenie pedagogów do „nastroju profanującego uroczystość”. Już w kilka dni po zajściu odbyło się nadzwyczajne posiedzenie Komitetu Pedagogicznego, na którym miano zadecydować o dalszym losie uczniów - inicjatorów zdarzenia ${ }^{31}$.

Szczególnie aktywnie brali udział członkowie „Żagwi” w obchodach rocznicy śmierci Tadeusza Kościuszki w 1917 r. ${ }^{32}$ W październiku 1917 r. delegaci organizacji znaleźli się w Głównym Komitecie Obchodów Rocznicy Śmierci T. Kościuszki ${ }^{33}$. „Żagiew” zorganizowała wówczas w sali kinematografu Luna przy ul. Przejazd (obecnie ul. Tuwima) akademię ku czci polskiego bohatera. W imieniu organizacji odczyt wygłosił Menkes, który przypomniał m.in. postać Berka Joselewicza oraz cel „Żagwi”, tj. uświadomienie ludności żydowskiej, że jej zadaniem nie była walka o prawa mniejszości lecz o prawa większości, prawa ludu. Kolejnym prelegentem był Konrad Urbach, który charakteryzując postać i dokonania T. Kościuszki przekonywał, że klęska pod Maciejowicami (10 października 1794 r.) była symbolem przeciwieństw obecnych w ówczesnym narodzie polskim i dowodem na niezrozumienie wielkich haseł wolnościowych przez szlachtę. Prelegent przytoczył list T. Kościuszki do cara Aleksandra I, który to miał być dowodem na realną politykę prowadzoną przez bohatera. Kolejnym punktem imprezy były deklamacje Machenholtza (Pogrzeb Kościuszki Kornela Ujejskiego) oraz Spiro (Ojczyzna i Do grobów prof. Bronisława Knothego).

uczestniczyła zwykle w nabożeństwach w synagodze przy ul. Wolborskiej. Podobne zwyczaje posiadały pozostałe łódzkie szkoły średnie, APŁ, Prywatne Gimnazjum i Liceum Męskie Zgromadzenia Kupców miasta Łodzi (dalej: PGiLMZKmL), sygn. 126, k.127, Protokół obchodów rocznicy uchwalenia Konstytucji 3 Maja; tamże, Gimnazjum Męskie A. Zimowskiego (dalej: GMAZ), sygn. 30, k. 20, Protokół rady pedagogicznej z dn. 7 V $1916 \mathrm{r}$.

${ }^{29}$ Hymn Nadzieja (hebr. Hatikva) - pieśń autorstwa galicyjskiego Żyda, Naftaliego Herca Imbera, który w 1882 roku wyemigrował do Palestyny. Treścią hymnu jest pragnienie utworzenia państwa żydowskiego. W 1897 roku utwór stał się hymnem Światowej Organizacji Syjonistycznej. W 1948 roku Nadzieja stała się nieoficjalnym hymnem państwa Izrael. W 2004 roku została zatwierdzona przez Kneset jako hymn oficjalny; patrz: A. Chwalba, Historia Polski 1795-1918, Warszawa 2000, s. 525.

${ }^{30}$ Organizacja Drużyn Harcerskich im. Tadeusza Kościuszki - żydowska organizacja harcerska działająca pod patronatem „Harcerza Polskiego”, grupująca młodzież w wieku od 12 do 21 lat; organizacja posiadała propolski charakter; patrz: APŁ, GiLMZKmŁ, sygn. 293, k.2-5, Pismo stowarzyszenia „Harcerz Polski” do dyrektorów szkół średnich z dn. 25 I 1917 r.; „Harcerz Polski”. Jednodniówka drużyn skautowych im. T. Kościuszki w stuletnia rocznicę zgonu i patrona, Łódź 1917.

${ }^{31}$ Szerzej: A. Stawiszyńska, Problemy wychowawcze w łódzkich szkołach średnich w latach I wojny światowej, „Kultura i Wychowanie”, t. VI/2013, s. 30-32.

32 APŁ, ZDiPU, sygn. 452, k. 4, Łódzki Komitet obchodów 100 rocznicy zgonu T. Kościuszki.

${ }^{33}$ GE, 5 X 1917, nr 274, s. 3. 
Całość dopełniły pieśni narodowe, tj. odśpiewano Boże coś Polskę oraz Rotę z 1830 r. ${ }^{34}$ Podczas obchodów w synagodze przy ul. Wolborskiej, członkowie „Żagwi” pełnili wartę honorową przed ołtarzem wraz z Drużynami Skatowymi im. T. Kościuszki ${ }^{35}$. Ze wspomnianej okazji organizacja wydała też ulotkę [Obywatele Żydzi!], w której akcentowała tolerancję naczelnika, gdyż „Kościuszko nikogo nie odpychał od Polski”, a także wspominała współpracowników T. Kościuszki - B. Joselewicza i Józefa Aronowicza i rolę osób pochodzenia żydowskiego w walce o niepodległą Polskę ${ }^{36}$. W kolejnej odezwie podkreślano, że w szeregach walczących nie zabrakło polskich Żydów, a „rycerska postać Berka Joselewicza bohaterskiemi czyny zapisała się na kartach dziejów Polski" ${ }^{37}$.

W podobnym tonie wypowiadano się podczas, przypadającej w 1918 r., 55. rocznicy wybuchu powstania styczniowego, podając za wzór rabinów Majzla, Wohla, Jastrowa przekonując, że: „Wiara ojców nie przeszkadzała miłować gorąco Ojczyznę na równi z wszystkimi najlepszymi synami jednej i tej samej ziemi”38.

Członkowie organizacji byli inwigilowani przez władze niemieckie. Jesienią $1917 \mathrm{r}$. w Warszawie aresztowano przywódcę ugrupowania Leona Bergamana oraz działacza K. Winauera. Obydwu wytoczono proces o przynależność do nielegalnego związku oraz wydawanie pisma. W tym czasie miała miejsce rewizja w redakcji wydawanego przez „Żagiew” pisma. Wszystko to wpłynęło na ograniczenie działalności związku. Podobne działania władz niemieckich miały miejsce w innych miastach, także w Ło-

${ }^{34}$ Nie wiadomo, czy chodziło o Pieśn Legionów Polskich we Włoszech (Mazurek Dąbrowskiego) Józefa Wybickiego czy o pieśń Cześć polskiej ziemi, cześć, GŁ 15 X 1917, nr 284, s. 3; „Godzina Polski” (dalej: GP), 16 X 1917, nr 284, s. 5.

35 GŁ, 16 X 1917, nr 285, s. 1; GP, 16 X 1917, nr 284, s. 5; „Nowy Kurier Łódzki” (dalej: NKŁ), 16 X 1917, nr 282, s. 1; J. Załęczny, Obchody kościuszkowskie w 1917 r. elementem kształtowania tożsamości Polaków: (na podstawie pamiątek ze zbiorów Muzeum Niepodległości), „Niepodległość i Pamięć”, t. 22/3(51)/2015, s. 40.

${ }^{36}$ W odezwie czytamy: „17 IX 1794 r. wydana została przez Kościuszkę proklamacya, w której obwieszcza, iż dwaj obywatele, Berek Joselewicz i Józef Aronson „starozakonni pamiętni na ziemię, w której się urodzili, pamiętni tego, że z oswobodzenie jej wraz z drugimi wszystkie korzyści czerpać z niej będą, otrzymali oni patent na formowanie pułku starozakonnych - dzień ten winien być dla Żydów polskich dniem wielki i pamiętnym, bo jest dniem otrzymania święceń obywatelskich [...]”, APŁ, ZDiPU, sygn. 235, k. 6, Ulotka [Obywatele Żydzi!] Związek Młodzieży Polskiej Pochodzenia Żydowskiego „Żagiew”, 1917 r.

37 APŁ, ZDiPU, sygn. 235, k. 8, Ulotka [Obywatele! Współwyznawcy!], „Żagiew”, 15 X 1917 r., Łódź

38 APŁ, ZDiPU, sygn. 235, k. 6, Odezwa Związku Młodzieży Polskiej Pochodzenia Żydowskiego Żagiew; tamże, k. 8, Ulotka Związku Młodzieży Polskiej Pochodzenia Żydowskiego Żagiew z dn. 15 X 1917 r.; tamże, sygn. 237, k. 21, Odezwa Związku Młodzieży Polskiej Żagiew z d. 22 I 1918 r.; tamże, k. 22, Program uroczystego obchodu Powstania Styczniowego staraniem Koła Łódzkiego Młodzieży Polskiej Żagiew. 
dzi. Miejscowe Cesarsko-Niemieckie Prezydium Policji poszukiwało K. Urbacha oraz kilku innych wpływowych działaczy, a także starało się wykryć lokal organizacji ${ }^{39}$.

Większość członków łódzkiej „Żagwi” była też członkami Polskiej Organizacji Wojskowej (POW). Wobec stałego zagrożenia ze strony władz niemieckich, działalność „Żagwi” ograniczała się przez pewien czas do pracy agitacyjnej oraz oświatowej ${ }^{40}$.

„Żagiew” reagowała na bieżące wydarzenia. W listopadzie 1916 r., po wydaniu tzw. Aktu 5 Listopada, „Żagiew” wydała ulotkę [Żydzi polscy!], w której uznawała wspomniane wydarzenie za wiekopomny akt w dziejach: „Dzień ten zapowiada kres tragicznych dziejów Polski. Kto nie czuł poprzednio bólu Polski, kto nie współdziałał w Jej samoobronie przeciw zagładzie, upragnionej przez wroga, był złym synem Polski, niedobrym obywatelem kraju. Lecz kto dziś nie umie odczuć w sercu swem radości naszej Ojczyzny, jest niegodnym przybywania na tej ukochanej naszej ziemi!”41.

W lutym 1918 r. miał miejsce wiec „Żagwi” zorganizowany z myślą o młodzieży akademickiej i gimnazjalnej. Podczas niego wygłoszony został odczyt „Obecny stan sprawy żydowskiej w Państwie Polskiem”. Po odczytaniu dokumentu miała miejsce ożywiona dyskusja z przedstawicielami syjonistów. Ostatecznie większością głosów wiec przyjął następującą rezolucję: „Młodzież polska bez różnicy wyznania i pochodzenia, zebrana na wiecu d. 9-tego lutego 1918 r., zwołanym z inicjatywy Związku Młodzieży Polskiej »Żagiew« stwierdziła, że jedynym środkiem rozwiązania kwestii żydowskiej w Państwie Polskiem jest przyciągnięcie pozostałej na wojnie wszechświatowej masy żydowskiej na ziemiach naszych, do kultury polskiej oraz szlachetności i ideałów polskich”. W dokumencie domagano się także odrzucenia przez rząd polski żądań żydowskich separatystów, a także przeciwstawiano się pomysłom wprowadzenia żargonu (język jidysz) do szkół, co miało być przejawem promowania kultury niemieckiej. Za groźne uczestnicy wiecu uznali też próby interwencji Żydów zagranicznych, głównie niemieckich i amerykańskich w sprawy polskie. Kwestia ludności żydowskiej na ziemiach polskich była wedle uchwały wiecowej „bezwzględnie sprawą wewnętrzną państwa polskiego”. Za istotne uznawano: „szerzenie kultury polskiej wśród mas zamieszkujących ziemie polskie, które jej jeszcze nie wchłonęły" ${ }^{42}$. Odezwa nie precyzowała dokładnie przyszłego ustroju Polski, nie wspominała np. o zwołaniu sejmu ${ }^{43}$.

39 Brak informacji na temat, czy wspomniane osoby zostały schwytane, „Żagiew”, nr 1-2/1919, s. $12-13,21$.

40 „Żagiew”, nr 1-2/1919, s. 21.

${ }^{41}$ APŁ, ZDiPU, sygn. 235, k. 4, Ulotka [Żydzi Polscy!], Związek Młodzieży Polskiej Pochodzenia Żydowskiego, „Żagiew”, XI 1916 r.

${ }^{42}$ GŁ, 24 II 1918, nr 54, s. 2.

${ }^{43}$ L. Hass, Do genezy złudzeń parlamentarnych w Polsce międzywojennej: (Sejm i głosowania powszechne w propagandzie politycznej Królestwa 1915-1918), „Kwartalnik Historyczny”, R. 79, nr 1/1972, s. 59. 
We wrześniu 1917 r. łódzki oddział „Żagwi” wydał pierwszy numer pisma „Uwagi - kartki poświęcone pracy polskiej wśród Żydów”. Zawierał on dwa artykuły - $\mathrm{Na}$ sza ideologja oraz przedruk tekstu Dwaj Hirszhornowie z „Das Jüedische Wort”44.

15 lutego 1917 r. grupa łódzka „Żagwi” wydała ulotkę [Koledzy!], w której nawoływała do wytężonej pracy, wzorowanej na działalności „Żagwi” w stolicy ${ }^{45}$, w której pisano: „Łódź bardziej niż jakiekolwiek inne miasto w Królestwie wymaga podobnej [do Warszawy - AS] organizacji. Miasto nasze stało się terenem najzajadlejszej agitacji nacjonalistów żydowskich i ich godnych towarzyszy z obozu syjonistycznego. Gdy starsze społeczeństwo milczy, Ojczyzna wkłada na nas - młodzież polską pochodzenia żydowskiego obowiązek pracy wśród ciemnych mas otumanionych przez panów z różnych »Centralnych Komitetów Żydowskich«. Grono młodzieży łódzkiej pochodzenia żydowskiego rozpoczęło już w porozumieniu z młodzieżą stolicy, prace organizacyjną. Od was koledzy zależy, by praca ta przybrała należyte rozmiary”. Z dumą podkreślano, że po wydaniu Aktu 5 Listopada żadne inne ugrupowanie żydowskich asymilatorów, poza „Żagwią”, nie wydało stosownej odezwy ${ }^{46}$.

W styczniu 1918 r. władze centralne organizacji postanowiły dokonać szeregu zmian w organizacji - postanowiono m.in. rozszerzyć działalność na cały obszar Królestwa Polskiego. Przebudowie miały ulec struktury - do włączenia się w działalność „Żagwi” planowano zaprosić osoby starsze, cieszące się autorytetem społecznym, które miałyby reprezentować organizację w kontaktach z Radą Narodową oraz Radą Stanu. Planowano wystąpić do Rady Narodowej z prośbą o opiekę oraz udzielenie stosownych dyrektyw. Zarząd organizacji miał być powiększony do 11 osób (4 uczniów, 5 akademików oraz 2 osoby starsze), a także planowano stworzyć Wydział Wykonawczy składający się z ucznia, akademika i osoby starszej. Najważniejszym zadaniem było wystąpienie do Rady Stanu z prośbą o legalizację organizacji ${ }^{47}$.

10 listopada 1918 r. „Żagiew” wydała odezwę, w której wyraziła solidarność z młodzieżą polską ${ }^{48}$. Wzywała też swoich członków, zdolnych do noszenia broni, by udali się „pod sztandary narodowe”. Zapowiedziano też zawieszenie działalności

\footnotetext{
44 „Żagiew”, 15 X 1917, nr 5-6, s. 26-27.

45 Wspomniana odezwa została też opublikowana na łamach „Żagwi”, tamże, II, nr 1-2/1917,
} s. 15 .

46 APŁ, ZDiPU, sygn. 235, k. 3, Ulotka [Koledzy!] z dn. 15 II 1917 r.

47 „Żagiew”, II 1917, nr 1-2, s. 16-17.

4810 listopada 1918 r. rozpoczęła się akcja rozbrajania Niemców na ulicach Łodzi. Brali w niej udział także uczniowie miejscowych szkół, głównie członkowie harcerstwa. W celu koordynacji akcji Główny Inspektorat Harcerski powołał do życia Pogotowie Młodzieży. Akcja ta spotykała się z niechęcią większości nauczycieli. Podczas akcji opanowania budynku Prezydium Policji śmierć poniósł Stefan Linke, uczeń Gimnazjum „Uczelnia” (obecnie I LO w Łodzi), T. Bogalecki, Rozbrajanie Niemców na ulicach Łodzi w listopadzie 1918 r., [w:] K. Badziak, J. Szymczak (red.), 75-lecie odzyskania niepodległości przez Polskę. Materiały z sesji naukowej, Łódź 12 XI 1993, Polskie Towarzystwo Historyczne, Łódź 1993, s. 64, K. Jurek, Lilijka i łódka..., dz. cyt., s. 31; S. Rachalewski, Zastygły nurt życia. Łódź, która odeszła, Zarząd miasta Łodzi, Łódź 1938, s. 83; A. Stawiszyńska, Łódź w latach..., dz. cyt., s. 689-690. 
Związku do czasu wywalczenia niepodległości. W wydanej wówczas uchwale podkreślano rolę Józefa Piłsudskiego ${ }^{49}$.

„Żagiew” starając się realizować hasła asymilacji ludności żydowskiej z narodem polskim, podejmowała także działania o charakterze edukacyjnym. We wrześniu 1917 r. zorganizowała kursy języka polskiego dla analfabetów żydowskich ${ }^{50}$.

Jak wspominałam wcześniej, członkowie „Żagwi” skonfliktowani byli z rówieśnikami skupionymi w organizacjach syjonistycznych. W marcu 1918 r. w sali organizacji „Markez” miało miejsce spotkanie syjonistycznej młodzieży żydowskiej uczęszczającej do miejscowych szkół średnich. Organizatorzy przedstawili referat poświęcony walce $\mathrm{z}$ ugrupowaniami asymilatorskimi, a także nawoływali do odrodzenia narodowego na ziemi żydowskiej. Wywołało to sprzeciw obecnych na sali sympatyków „Żagwi”, określanych przez prasę syjonistyczną „uczniami Nusbauma”, którzy demonstracyjnie opuścili spotkanie ${ }^{51}$.

Po odzyskaniu niepodległości „Żagiew” kontynuowała swoją działalność, deklarując te same poglądy i ideały co w czasie Wielkiej Wojny ${ }^{52}$.

Wzmożenie działalności łódzkiej „Żagwi” miało miejsce po pogromie ludności żydowskiej we Lwowie w listopadzie $1918 \mathrm{r} \cdot{ }^{53}$ Podczas zwołanego nadzwyczajnego zebrania, K. Urbach w następujący sposób objaśnił zebranym sytuację polityczną: „Wypadki lwowskie, choć wstrząsnęły nas do głębi, jednakże w niczem nie zachwiały ani naszej miłości do kraju ojczystego, ani przekonania, że sprawa żydowska w Polsce tylko w myśl naszej ideologii rozwiązaną być może". Zadecydowano wówczas o wzmocnieniu prac agitacyjnych. Utworzono Radę Związkową składającą się w 30 członków. Zainicjowano też cotygodniowe spotkania w celu omawiania kwestii bieżących. Pod koniec 1918 r. łódzka „Żagiew” prowadziła intensywne prace na terenie Piotrkowa Trybunalskiego, Zgierza i Pabianic. Organizacja utrzymywała też dobre kontakty z Organizacją Ludowych Drużyn Junackich im. Berka Joselewicza, która wówczas miała 6 drużyn skupiających 350 junaków. Po odzyskaniu niepodległości działalność

${ }^{49}$ APŁ, ZDIPU, sygn. 235, k. 1, Uchwała Łódzkiego Okręgu Związku Młodzieży Polskiej Pochodzenia Żydowskiego „Żagiew”; M. Bandurka, Narodziny niepodległej Łodzi w świetle ówczesnych źródet, [w:] S. Pytlas, H. Siemiński (red.), O suwerenność państwową i narodową. W 80-ta rocznice odzyskania niepodległości przez Polskę. Materiały z sesji naukowej, Łódź 10 XI 1998, Muzeum Tradycji Niepodległościowych, Łódź 1999, s. 68; GP, 10 XI 1918 nr 209, s. 7.

${ }^{50}$ GP, 10 IX 1917, nr 248, s. 3.

${ }^{51}$ GP, 10 III 1918, nr 68, s. 5.

${ }^{52}$ W pierwszym powojennym wydaniu pisma „Żagiew” czytamy: „Zwalczaliśmy, zwalczamy i nadal zwalczać będziemy wszelkie ruchy separatystyczne; zwalczamy teorie szowinistyczne, hasła demagogiczne i stanowczo protestujemy przeciw nadawaniu jakiejkolwiek części ludności pewnych praw specjalnych [...]”, „Żagiew” IV, nr 1-2/1919, s. 2.

${ }_{53}$ A. Biedrzycka, Kalendarium Lwowa 1918-1939, Kraków 2012, s. 1-3; M. Klimecki, Lwów 1918-1919. Z dziejów walk o polskie Kresy, Towarzystwo Autorów i Wydawców Prac Universitas, Warszawa 2016, s. 134-137; tenże, Wojna polsko-ukraińska. Lwów i Galicja Wschodnia 1918-1919. Pierwszy konflikt zbrojny odrodzonej Polski, Warszawa 2014, s. 137-139; J. Tomaszewski, Lwów, 22 listopada 1918 r., „Przegląd Historyczny”, t. 75/1984, s. 279-285. 
łódzkiej „Żagwi” uległa znacznemu ograniczeniu ze względu na fakt, że ok. 75\% jej członków znalazło się w szeregach Wojska Polskiego, a sama organizacja nawoływała swoich sympatyków do walki w obronie granic Polski. Podczas tych walk, na Kresach poległo dwóch członków łódzkiej „Żagwi”, tj. członek POW Kazimierz Gutentag oraz Szymon Lewi ${ }^{54}$.

Organizacją młodzieżową o podobnym, asymilatorskim charakterze była Organizacja Drużyn Harcerskich im. T. Kościuszki przy Stowarzyszeniu „Harcerz Polski”, zwana w skrócie „Harcerzem Polskim” ${ }^{5}$. Na gruncie łódzkim działały też młodzieżowe organizacje syjonistyczne, takie jak Kadima czy Ha-Szomer ha Cair ${ }^{56}$.

Koniec działalności „Żagwi” nastąpił w 1924 r., gdy organizacja weszła w skład Związku Akademickiej Młodzieży Zjednoczeniowej ${ }^{57}$.

Przez kilka lat na gruncie łódzkim działał Związek Młodzieży Polskiej Pochodzenia Żydowskiego „Żagiew” skupiający młodzież żydowską. Organizacja reprezentowała kierunek asymilatorski. W czasie Wielkiej Wojny uczestniczono aktywnie w działaniach związanych ze sprawą polską, jak choćby w obchodach polskich rocznic narodowych. Także „Żagiew”, zarówno w okresie wojennym jak i powojennym, widziała rozwiązanie kwestii żydowskiej w niepodległym państwie polskim, stąd tė̇ członkowie toczyli spory choćby z organizacjami syjonistycznymi, które dążyły do osadnictwa poza terytorium Polski. Łódzka organizacja „Żagwi” raczej nie miała zbyt wielkich wpływów w środowisku żydowskiej młodzieży.

\section{Bibliografia}

\section{Archiwalia:}

Archiwum Państwowe w Łodzi:

Gimnazjum Męskie A. Zimowskiego.

Prywatne Gimnazjum i Liceum Męskie Zgromadzenia Kupców miasta Łodzi. Zbiór Druków i Pism Ulotnych.

\section{Prasa:}

„Gazeta Łódzka”. „Godzina Polski”.

\footnotetext{
54 „Żagiew”, nr 1-2/1919, s. 22; M. Hrycek, Wątki antysemickiej w „Kurierze Łódzkim” w okresie międzywojennym, „Acta Universitatis Lodziensis. Folia Litteraria Polonica”,t.17/2012, s.21;A.Landau-Czajka, Odrodzona Polska czy odrodzona ojczyzna? Odzyskanie niepodległości w świetle polskojęzycznej prasy żydowskiej 1918-1929, „Dzieje Najnowsze”, R. XLIII, z. 3/2011, s. 69.

${ }_{55}$ Szerzej: K. Jurek, Organizacja skautowa..., dz. cyt., s. 34-37.

${ }^{56} \dot{Z} y d z i$ w Polsce..., dz. cyt., s. 128, 234.

${ }^{57}$ R. Żebrowski, Związek Akademickiej Młodzieży Zjednoczeniowej, [w:] Polski słownik judaistyczny: dzieje - kultura - religia - ludzie, t. 2, dz. cyt., s. 839.
} 
„Harcerz Polski”. Jednodniówka drużyn skautowych im. T. Kościuszki w stuletnią rocznicę zgonu patrona, Łódź 1917.

„Nowy Kurier Łódzki”.

„Żagiew”.

\section{Czasopisma:}

„Acta Universitatis Lodziensis. Folia Historica”.

„Acta Universitatis Lodziensis. Folia Litteraria Polonica”.

„Annales Universitatis Paedagogicae Cracoveinsis. Studia ad Bibliothecarum Scientiam Pertinentia".

„Dzieje Najnowsze”.

„Harcerstwo”.

„Kronika Miasta Łodzi”.

„Kultura i Wychowanie”.

„Kwartalnik Historyczny”.

„Niepodległość i Pamięć”.

„Przegląd Historyczny”.

„Rocznik Historii Czasopiśmiennictwa Polskiego”.

„Skaut”.

„Znak”.

\section{Opracowania:}

Bandurka M., Narodziny niepodległej Łodzi w świetle ówczesnych źródeł, [w:] S. Pytlas, H. Siemiński (red.), O suwerenność państwowa i narodową. W 80-ta rocznicę odzyskania niepodległości przez Polskę. Materiały z sesji naukowej, Łódź 10 XI 1998, Muzeum Tradycji Niepodległościowych, Łódź 1999.

Biedrzycka A., Kalendarium Lwowa 1918-1939, Towarzystwo Autorów i Wydawców Prac Universitas, Kraków 2012.

Bogalecki T., Rozbrajanie Niemców na ulicach Łodzi w listopadzie 1918 r., [w:] K. Badziak, J. Szymczak (red.), 75-lecie odzyskania niepodległości przez Polskę. Materiały z sesji naukowej, Łódź 12 XI 1993, Polskie Towarzystwo Historyczne, Łódź 1993.

Bojarska A., Urban, Krajowa Agencja Promocyjna, Gdańsk 2000.

Brzoza Cz., Prytucki Nojach, Kto byt kim w Drugiej Rzeczypospolitej, red. nauk. J.M. Majchrowski przy współpracy G. Mazura i K. Stepana, BGW, Warszawa 1994.

Chwalba A., Historia Polski 1795-1918, Wydawnictwo Naukowe PWN, Warszawa 2000.

Fałkowski J., Mniejszość żydowska w parlamencie II Rzeczypospolitej (1922-1939), Oficyna Wydawnicza AFM, Kraków 2006.

Fałkowski J., Posłowie żydowscy w Sejmie Ustawodawczym 1919-1922, Instytut Filozoficzno-Historyczny Wyższej Szkoły Pedagogicznej, Częstochowa 2000. 
Fuks M., Prasa żydowska w Polsce w XIX i pierwszej połowie XX wieku (do końca II wojny światowej”), „Roczniki Historii Czasopiśmiennictwa Polskiego”, nr 12/1973.

Fuks M., Pryłucki (Priłucki) Noe (Noach, Nojach), Polski Słownik Biograficzny, t. XXVIII, Wydawnictwo Polskiej Akademii Nauk, Wrocław-Waszawa-Kraków-Gdańsk-Łódź 1984-1985.

Fuks M., Żagiew”. Pismo Młodzieży Polskie Pochodzenia żydowskiego, Polski słownik judaistyczny: dzieje - kultura - religia - ludzie, t. 2, opr. Z. Borzymińska i R. Żebrowski, Wydawnictwo Prószyński i S-ka, Warszawa 2003.

Gorycki L., Skauting mniejszości narodowych i etnicznych w II Rzeczypospolitej (cz. IV) Drużyny Skautowe im. berka Joselewicza, „Skaut”, R. XIII, nr 3/2017.

Guzik, M. Skoczeń, Żydowskie organizacje skautowe w Polsce w latach 1916-1945, „Harcerstwo”, R. XXXII, nr 1/1990.

Hass L., Do genezy złudzeń parlamentarnych $w$ Polsce międzywojennej: (Sejm i głosowania powszechne w propagandzie politycznej Królestwa 1915-1918), „Kwartalnik Historyczny", R. 79, nr 1/1972.

Hrycek M., Wątki antysemickiej w „Kurierze Łódzkim” w okresie międzywojennym, „Acta Universitatis Lodziensis. Folia Litteraria Polonica”, t. 17/2012.

Informator miasta Łodzi z kalendarzem na rok 1919, Magistrat miasta Łodzi, Łódź 1918. Jurek K., Lilijka i łódka. Historia harcerstwa polskiego do 1939 roku, Wydawnictwo Księży Młyn, Łódź 2006.

Jurek K., Organizacja skautowa młodzieży żydowskiej „Harcerz Polski”. Przyczynek do problematyki mniejszości narodowych w ZHP, „Harcerstwo”, R. XXVIII, nr 6/1986.

Kałuski M., W podzięce i ku pamięci Jankielom, Warszawa 2001.

Kaszubina W., Notatki o prasie łódzkiej, „Rocznik Historii Czasopiśmiennictwa Polskiego", nr 7/1/1968.

Klimecki M., Lwów 1918-1919. Z dziejów walk o polskie Kresy, Dom Wydawniczy Bellona, Warszawa 2016.

Klimecki M., Wojna polsko-ukraińska. Lwów i Galicja Wschodnia 1918-1919. Pierwszy konflikt zbrojny odrodzonej Polski, Bellona, Warszawa 2014.

Kozłowski Cz. (red.), Słownik organizacji młodzieżowych w Polsce 1918-1970, Iskry, Warszawa 1971.

Kwiecień S., Kartka z dziejów prasy dla dzieci i młodzieży w okresie autonomii galicyjskiej, „Annales Universitatis Paedagogicae Cracoveinsis. Studia ad Bibliothecarum Scientiam Pertinentia”, t. XIII/2015.

Landau-Czajka A., Odrodzona Polska czy odrodzona ojczyzna? Odzyskanie niepodległości w świetle polskojęzycznej prasy żydowskiej 1918-1929, „Dzieje Najnowsze”, R. XLIII, z. 3/2011.

Lichten J., Uwagi o asymilacji i akulturacji Żydów w Polsce wlatach 1863-1943, „Znak”, R. XL, z. 5-6/1988. 
Pajewski J., Historia powszechna 1871-1918, Państwowe Wydawnictwo Naukowe, Warszawa 1971.

Polonsky A., Dzieje Żydów w Polsce i Rosji, Wydawnictwo Naukowe PWN, Warszawa 2014.

Rachalewski S., Zastygły nurt życia. Łódź, która odeszła, Zarząd miasta Łodzi, Łódź 1938.

Rudnicki Sz., Żydzi w parlamencie II Rzeczypospolitej, Wydawnictwo Sejmowe, Warszawa 2015.

Starzycka M., Przetrwali na Piotrkowskiej. Mała łódzka historia, „Kronika Miasta Łodzi”, nr 1-2/2015.

Stawiszyńska A., Łódź w latach I wojny światowej, Napoleon V, Oświęcim 2016.

Stawiszyńska A., Problemy wychowawcze w łódzkich szkołach średnich w latach I wojny światowej, „Kultura i Wychowanie”, t. VI/2013.

Tomaszewski J., Lwów, 22 listopada 1918 r., „Przegląd Historyczny”, t. 75/1984.

Urbaniak R., Z dziejów prasy łódzkiej - „Republika” 1923-1925, „Acta Universitatis Lodziensis. Folia Historica”, t. 82/2008.

Wachowska B., Tradycje powstania listopadowego (1880-1942), „Acta Universitatis Lodziensis. Folia Historica”, t. 16/1983.

Załęczny J., Obchody kościuszkowskie w 1917 r. elementem kształtowania tożsamości Polaków: (na podstawie pamiątek ze zbiorów Muzeum Niepodległości), „Niepodległość i Pamięć”, t. 22/3(51)/2015.

Żebrowski R., Drużyny Harcerskie im. Berka Joselewicza, Polski słownik judaistyczny: dzieje - kultura - religia - ludzie, t. 1, opr. Z. Borzymińska i R. Żebrowski, Wydawnictwo Prószyński i S-ka, Warszawa 2003.

Żebrowski R., Ha-Szomer, Polski słownik judaistyczny: dzieje - kultura - religia ludzie, t. 1, opr. Z. Borzymińska i R. Żebrowski, Wydawnictwo Prószyński i S-ka, Warszawa 2003.

Żebrowski R., Związek Akademickiej Młodzieży Zjednoczeniowej, Polski słownik judaistyczny: dzieje - kultura - religia - ludzie, t. 2, opr. Z. Borzymińska i R. Żebrowski, Wydawnictwo Prószyński i S-ka, Warszawa 2003.

Żebrowski R, Żagiew, Polski słownik judaistyczny: dzieje - kultura - religia - ludzie, t. 2, opr. Z. Borzymińska i R. Żebrowski, Wydawnictwo Prószyński i S-ka, Warszawa 2003.

Żydzi w Polsce. Dzieje i kultura. Leksykon, pod red. J. Tomaszewskiego i A. Żbikowskiego, Wydawnictwo Cyklady, Warszawa 2001. 
The activity of the Association of Polish Youth of Jewish Origin „Żagiew" in Łódź during the First World War (1914-1918)

Abstract: For a few years in Łódź, the Association of Polish Youth of Jewish Origin "Żagiew" brought together Jewish youth. The organisation represented those who favoured assimilation. During the Great War, Poles were actively involved in activities related to the Polish cause, such as celebrating Polish national anniversaries. "Żagiew", both during the war and after the war, saw the solution to the Jewish question in an independent Polish state, and thus its members argued with Zionist organisations, which sought settlement outside of Poland. "Żagiew" in Lodz did not have much influence on Jewish youth.

Keywords: Lodz 1914-1918, Association of Polish Youth of Jewish Origin “Żagiew”, Jews in Lodz

About the author: Aneta Stawiszyńska (born 1983) - PhD in humanities; PhD dissertation written at the Department of Polish History of the Most Recent University of Lodz Eódź in the years of the First World War. Research interests: social history of the First World War, the history of the Lodz region. Publications: about 80 scientific and popular science articles devoted mainly to the history of Łódź and the region, and two books: Ruda Pabianicka. Echa przeszłości (2009) and Łódź w latach I wojny światowej (2016). 


\section{Andrej Rajský}

Trnava University in Trnava

\section{Ad unum vertere? Education as con-versio from multitude}

\section{What does it mean to "head towards one"?}

Western (Euro-Atlantic) culture has been formed with an awareness of its particularity in relation to other cultures and civilisations. The peak period of Greek antiquity brought logical thinking (logos) to the prevailing mythical thinking (mythos). This allowed the world to be looked at from a distance and a complex view to be created. Complexity and universal validity of knowing became a reason and aim of intellectual effort expressed in the notion philo-sophia (Pythagoras circa 580490 BC). Acquisition of a unified, complex view of the world became an intellectual, cultural and political ideal, inspiring the Western human to a new standard of cultural performance. "Gathering" (Lat. legere) of singularities and their arrangement into a meaningful whole represents the basic motive of intellectual work (the Latin word intellectus comes from the notion intus legere "to read inwardly") and in a broader sense, of each cultural activity. Vertere ad unum is thus legitimised by the very essence of cultural awareness. Epistemological and axiological universalism is based on an axiom that being precedes thinking and it is an objective source of knowledge of values. A mistake (scientific or moral) may occur only on the part of a subject due to a lack of agreement of their intellect with matter.

Our civilisation paradigm is based on a philosophical and religious belief about the substantial equality and value of all people no matter their accidental characteristics (health, wealth, power, social status, moral status, origin, affiliation, etc.). In Greek and Roman antiquity, the perception of human essence had a limited range (only a citizen was a fully valued human, i.e. barbarians, slaves and "inferiors" were not attributed full humanity), only with the epoch of Christianitas is human nature applied entirely in a universalistic manner. The essence of a human being, labelled as their physis in antiquity, as natura in the Middle Ages, and accurately expressed by the 
notion of humanitas in the first era of the Modern Times, provides a sufficient reason for a universal value of individual human dignity.

The advantages of universalism can be summarised into several elements. First of all, it is the concept of human nature that is the ontological fundament of human dignity and its ethical demands, regardless of individual differences. It implies general equality of humans, not only under the law, but also "in the eye of God", i.e. in terms of a transcendental, objective and metaphysical view. Moreover, the personal guarantee of God grants human dignity to every individual and is involved in the existential space of everyday life. The right of a neighbour or fellow citizen to equal and dignified treatment is directly reflected in the moral command of responsibility, solidarity and care. On these foundations, the theory of universal human rights was established and the Universal Declaration of Human Rights (1948) was proclaimed.

On the other hand, universalism hides within itself an ever-present germ of potential destructivity. In the history of the West, regrettable paradoxes emerge when, in the name of the "universal truth" a factual and inhumane exclusion of certain individuals and groups from the community of those who "deserve" dignitas humana occurs (colonialism, contemporary slavery, exploitation, conquering wars, genocide, pogroms, etc.). The original idea of a noble anthropological universalism is often misused in a degraded form in terms of power and ideology as a means of cultural hegemonisation or in the application of individual or collective power. The universalistic idea of human nature has been caught in a whirlwind of reduction metamorphoses, from which older as well as modern anthropological conceptions have emerged, claiming an unconditional interpretation of the world. The so-called great narratives of modernism (enlightenment emancipation, idealism, historicism, Marxism, Freudism, etc.) proved to be, from a contemporary perspective, homologising, centralistic, hidden or openly violent. Collectivistic approaches or segregation and elimination mechanisms (Nazi eugenics and genocide, Stalinism, regulation practices of communist dictatorships, etc.) have come to the fore instead of a respectful inclusive perspective.

Hellenic cultural hegemony, however, contained also an intellectual "brake", a warning against totalising dogmatism, illustrated by Socrates's statement in front of the Athenian tribunal: "Neither of us really knows anything fine and good, but this man thinks he knows something when he does not, whereas I, as I do not know anything, do not think I do either. I seem, then, in just this little thing to be wiser than this man at any rate, that what I do not know I do not think I know either"'. The medieval establishment of the Biblical religious belief about the created and the knowable ordo mundi, which is the source of objective and general human knowledge, at the same time, required a necessity of intellectual humility guaranteed by the transcendence of the divine Logos. The zeal for the truth and humility of seekers are

${ }^{1}$ Platón, Obrana Sokratova, [w:] A. Bröstl, Aténsky lud proti občanovi Sokratovi, Kalligram, Bratislava 2006, 21d. 
the two original elements of the Western dialectics. The misuse of the idea of universalism is still a threatening risk. An intellectual is not only constantly aware of this risk but also cultivates within him/herself an alert system of antitotalisation mobilisation.

There are principally two basic interpretations, a radical one and a moderate one, that can be considered the answer to the posed question of what it means to "head towards one". The radical interpretation understands universalism as a principle/ norm of an intentional or implicit totalisation and as an apology of normative and indoctrination impacts. It results in a form of totalitarianism, supported by a unifying ideology, governed from one centre. In education, this interpretation is manifested through normalisation, directive education, curricular centralism, social levelling and homogenisation of behaviour. The moderate interpretation of universalism presupposes a principle of unification, or "gathering" of experiences and opinions from multitude toward complexity, purposefulness, meaningfulness, or form. In education, this interpretation applies a certain teleological approach, focused on identified values, emphasising the ascendant educational process. Education is perceived as formation, acquisition of a form (Lat. formare, Ger. bilden), intentional abandonment of dispersion and amorphousness, toward a predicted higher quality of knowing, experiencing and acting. Certainly, not even the moderate interpretation of universalism is freed from the threat of misuse of power and manipulation. After all, due to these reasons - as a reaction to abusive treatment of ideas in our culture - the requirement of pluralism emerged.

\section{Ex uno plures}

Pluralism (Lat. pluralis, multiple, diverse) is a term encompassing attitudes, directions and theories that emphasise irreducible multiplicity and diversity. They are based on an assumption that an experience is too complex to be fully comprehended by a single view, single theory, derived from a single basic principle.

Pluralism, however, does not question the possibility of truthful knowledge and evaluation (that would be scepticism, relativism or agnosticism), it only points out that more complex themes imply multiple knowledge and evaluations, while it does not mean that some of them are necessarily incorrect. The concept of pluralism was introduced by the American philosopher William James in his work A pluralistic universe (1909) and since then it has spread to many fields where this problem occurs. In philosophy, first of all, ontological pluralism, then epistemological and axiological pluralism, are distinguished. Ontological pluralism is natural for us and it is the most commonly spread opinion: reality is composed of many essences, the being of the world is not just one (Parmenides) - even with various levels of emanation (Plotinus), but there are many beings, beginning with the Absolute being in the hierarchy of existences up to inanimate things. Reality itself is multifaceted, diverse, varied, differentiated. Oriental theories provided Plato with dualism (the world of ideas vs. 
material world), which also had a great influence on the initial Christian perception of the world and the human (gnostics, manicheists, heretics - theories of "the evil world and the evil body"). Slovak philosopher Ladislav Hanus sees a residuum of Platonic dualism in spiritualism, which is encountered even at present (devotism, supranaturalism). Representatives of spiritualism underestimate time, history, the physical body, nutrition, citizenship (as well as thinking, philosophy, literature, culture...). They ironically call those who do not share supranaturalism liberals, dandies, heretics - "this piety supranaturalism is returning at present" ${ }^{2}$. Descartes of modern times also found himself in psycho-physical dualism. Leibnitz attempted to overcome it (monads and pre-established harmony). Modernism, however, wanted to overcome scholastic metaphysics by setting new metaphysics that reflected the will of human beings to recreate the world to their image - it regarded voluntarist projects, resulting in universalistic (monistic) interpretations of the world and totalitarian, violent social forms. Postmodernism, in contrast to modernism, adopted pluralism as its major canon. Next, epistemological pluralism may be discussed: pluralism emphasises the multitude of various approaches, views and perceptions, resulting particularly from the limited possibilities of a human being. Experience is complicated and complex; a single theory, a single view derived from a single principle (gnoseological monism) does not suffice. Likewise, the evaluation of various phenomena and facts often cannot be definite because it depends on the viewpoint of an evaluator, on a situation, education, etc. (axiological and cultural pluralism).

The topic of difference that prevents a human being from exhausting the wealth and depth of being by reason is as old as philosophy itself. For example, a clear rational distinction between being itself (existence) and a being accessible to reason (essence), which should guarantee imperfection and plurality of knowledge, can already be found in Thomas. In the early modern times, the significance of differentiation started to subside in favour of the power of autonomous reason. The tradition of humanistic and enlightenment reliable rationality (universality), however, proved to be naively optimistic in the mid $-20^{\text {th }}$ century, mainly after historical experiences with war and totalitarian regimes. The seemingly guaranteed scientific indestructibility of the human spirit (from Hegel to Marx or Husserl) met strong scepticism and a massive resistance to uniformity and homogeneity, totality and structure of thinking, in which individuality and an individual, difference and originality, marginality and personal declaration ceased. Beginning with Heidegger and his ontological differentiation (Sein/Seiende) through the more socially-tuned theories of the French "philosophers of differentiation" (J. Derrida, M. Foucault, G. Deleuze, F. Guattari) and other postmodernists (J. Lyotard, K.-O. Apel, R. Rorty, G. Vattimo and others) the so-called "grand narratives" of modernism, along with their ideological justification of social cohesion and progress, are deconstructed and disarmed.

\footnotetext{
${ }^{2}$ L. Hanus, Princíp pluralizmu, Lúč, Bratislava 1997, pp. 38-39.
} 
According to Lyotard, in the postmodern age, grand narratives or meta-narratives (mainly enlightenment) lost their persuasiveness and thus a crisis in metaphysics in philosophy with its claim to universal validity occurred. These narratives, however, hit fractures that were brought to the unifying dialectics by phenomenology of the other/ Other (incomprehensible, unknowable, hidden, unrecognisable, mysterious...). And thus, in the very bosom of modernism, paradoxically, a requirement of postmodernism appears: the fracture and distance of the subject from the reference, unification and orientation structure of being. Postmodernism does not require a historical or meta-historical base, it is satisfied with temporary self-understanding in the background of a minimal, "little", historically situated horizon of sense. On the other hand, postmodernism does not represent any "clear alternative" to modernism because it constantly moves in the horizon of meanings that modernism has historically abandoned. The difference between them resides rather in "lightening up" and dissolving the emancipation dynamics that made modernism an epoch of a unified image of the world ${ }^{3}$. The idea of difference frees an individual from the necessity to adapt his/ her own identity to the identity of majority culture and society, which, supported by legitimation mechanisms, unifies all thinking and acting to generally set templates of normality, using all the means of a more or less hidden physical, legal, political, ideological and moral manipulation. Postmodernism breaks down this cultural continuity and social monolith into fragments in the name of pluralism, relativism and diversity.

If the ambivalence of universalism was pointed out above, then in the case of pluralism, ambivalence appears to be its obligatory building element, which is reflected both in its advantages and limitations. General pluralism of life philosophies in particular and tolerance to differences in opinions and life styles enable free choice of values and criteria of acting, without the pressure to submit to the dominant and selective imperative. Every individual is incomparable to another individual, since their own individuality offers sufficient means for realisation of meaning. Otherness is not understood as abnormality but as a legitimate status of every human being. A palette of many differences creates diversity, variety and multiculturality in a society. Unlimitedness, or flexibility and variability of norms, rules and modules, contributes to action-based, mobility-based and situation-based orders and solutions.

Limitations of this paradigm result from the same presuppositions as its advantages. Above all, the ontological fundament that would ensure existential dignity for every human being regardless of circumstances and particularities gets lost here. As a result, there is an absence of a unified moral command, or a moral rule that would make us/force us toward responsibility, solidarity and care for the other. Every act of this kind is left rather upon a situational, emotional or conditional setting (mood), or legally conditioned (unsympathetic) duty. Relativism as a cultural axiom ceases to be

${ }^{3}$ Cf. A. Rajský, Nihilistický kontext kultivácie mladého človeka. Filozoficko-etický pohlad, TUT/ Veda, Trnava 2009. 
relative (facultative) itself, it becomes prescriptive (so-called "dictate of relativism") and takes people to secondary global homogeneity. It means that the idea of pluralism cannot avoid a paradox. The paradigm of plurality is at present a unified approach in perception of the contemporary world and events. However, a generally accepted pluralist approach confirms an existence of a unified image of thinking, even though at a metaphilosophical level. It is an autocontradiction: affirmation of absolute plurality of various regional philosophies uses a metaregional horizon that fulfils a function of continuum. The paradox of the paradigm of radical plurality resides in its universal character. If we accept the assumption that every exclusive claim comes from an illegitimate promotion of the particular to the universal, then this is done by the paradigm of absolute pluralism: one approach in thinking is promoted to a universal model of philosophy and culture in general. Absolute diversity of philosophical conceptions (as well as educational conceptions and all humanities) is unsustainable.

\section{Polyphony as a philosophical metaphor}

A certain starting point for the search for a common denominator of various philosophies may be the fact that even original forms of philosophy are not spontaneous creations of the human spirit. All great philosophical systems are born out of a mutual dialogue and in a mutual dependence, regardless of whether they confirm or refute each other or form a new synthesis. There is an osmosis relationship among them (H. Urs von Balthasar: Truth is Symphonic). In this perspective, Plato presupposes Parmenides and Heraclitus, Aristotle is unthinkable without Plato, and Thomas Aquinas without Augustine and the Dionysus of Areopagite. Humankind thinks symphonically, or polyphonically. The basic intuitions of great philosophers are often a synthesis of ideas of other thinkers.

Thus, philosophising actually helps to keep the torchlight of the search burning that could otherwise be extinguished either by resignation or reduction to ideology. Philosophical activity is therefore in the centre between the resignation and the titanic claim of knowledge of all secrets of existence. It is an art of avoiding a temptation of all philosophical systems that would like to build a stable and closed roof as a crown of their constructions. Genuine philosophising is therefore implied in all philosophical conceptions whose common denominator is inquietum cor (Augustine, Confessions I, 1). In other words, authentic philosophy cannot avoid the question of difference between the cause of the world and the existence of the world.

However, the plurality of various philosophical conceptions does not mean a pure multitude of mutually incongruent systems. As Hanus reminds us, the Latin term pluralitas consists of the root plus, that is, more. It is actually comparative in regard to multum: from the etymological perspective, plurality is therefore more than a simple sum of several elements. For this reason, he proposes to translate the word pluralitas as "moreness", not an indicative - a statement of multitude, but as an "ethical imper- 
ative" . The principle of pluralism, the real differentiation of esse/essentia, is actually the principle of "moreness": existence is more than a set of phenomena or facts; rationality is more than a certain number of various rules of thinking and communication; philosophy is more than a system of certain statements. Language, thinking and existence itself assumes an appropriate act (a priori) that is a source of its formal intelligibility (a posteriori). Therefore, philosophising cannot be reduced to sole analysis of the formal structure of language: philosophy cannot avoid the secret that is related to people in the depth of their being. Philosophy asks what the soul of every human search, knowledge and effort is. It can be deduced from the real difference esse/essentia that this base cannot be grasped and determined in an exhaustive way by our formal descriptions, definitions and argumentations, although every affirmation implies it as its necessary assumption and its part. This fundament, however, is not an object of the present paper.

\section{The "organic pluralism" of Ladislav Hanus}

In his work Princíp pluralizmu [tr. Principle of Pluralism] (the manuscript 1967 was kept in a drawer for 30 years) the Slovak philosopher of culture and a dissident intellectual partially followed the personalistic thinking of J. Maritain and R. Guardini, however, from the perspective of the development of Western thought, he even overcame them in a way. Hanus clarifies that pluralism is not only a theoretical position, it is an existential experience, related to the freedom of a human. He distinguishes pluralism as a) an idea concept, that is, a worldview approach, and b) a program of acting, while a connection of both aspects creates pluralism as a principle by which constituting of the worldview as well as the method of practice is governed. Pluralism is not a discovery of the contemporary age, it is a result of a thousand-year-long historical struggle against exclusive monisms, a result of a reflected experience and its validation.

Pluralism has two basic tasks: 1) towards multitude (to see, accept and assess all plurality elements of a community), 2) towards unity (to lead multitude to unity - to "integrate" it). Unity stated here is not a totalitarian, homogenising, centralistic unity (a unity of the "herd" or a "state of termites"), it is an organic unity. The only legitimate means to reach such a unity is a means that is exclusively human, "decent to a human", and that is a dialogue. Through dialogue it will be possible to reach for "multitude in unity, unity in multitude" . On the contrary, the highest enemy of pluralism is voluntarism - violence whose consequence is uniformisation of the other "underneath". In an integrated plural society, diffuse multitude, particularism, subjectivism, isolationism and individualism do not take place. Hanus's organic pluralism reacts to the

\footnotetext{
${ }^{4}$ L. Hanus, Princíp pluralizmu, Lúč, Bratislava 1997, p. 33.

5 Ibid., p. 33.
} 
problematic antimetaphysical "modern period", in which fragmentation into pieces, disjunction, detachment prevail - according to him, late nominalism reaches its peak, with the loss of the whole and of unity, when a-personal rationalism and empiricism reduce a human being to an object. Hanus could not have reflected the differentiation of modernism and postmodernism (cf. F. Lyotard), in which postmodern authors blame modernism for paranoia (creation of modern utopias of life - violently totalising - as the manifestation of fear, paranoia - fear of God, nature and heteronomy...), however, they could not avoid "postmodern paranoia" themselves (fear of everything unifying, great narratives, voluntarism, universalism of any kind). Hanus's criticism of the "modern period", from my point of view, refers rather to what is "post-modern".

Pluralism is situated in the middle position between etatism (monism, collectivism) and individualism ("liberalism", solipsism). In Hanus's theory, the socio-political level is closely connected with the anthropological and ethical level. "Every worldview may be reliably evaluated by recurring it to its notion of a human"6. With regard to a particular human being, Hanus notes that a person defends him/herself against merging with a collective body as well as against his/her own isolation ${ }^{7}$. For this reason, Hanus rejects both extreme individualism/liberalism and collectivism.

"An individualist rejects and refuses any attachment: political, state, economic, as

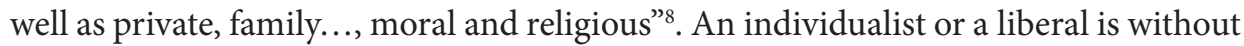
any bounds and duties "to any positive counterpart" and, thus, they head toward "the emptiness of nihilism" . Eventually, "they cannot handle the achieved state of boundlessness"10. In case of liberalism/individualism, plurality is kept in its multitude, shattered chaos. Individualism refers to the negative concept of freedom - it understands it as boundlessness. Hanus stresses the need of a positive concept of freedom, free bounding. On the other hand, Hanus, together with Guardini, rejects collectivism and blames it for objectification of the human being:

It is much easier to think in categories of objects than in personal categories. And it is easier to work in them. They are smoother, handier. Biological categories are more handsome than mental ones, mechanical are more handsome than biological ones. [...] They can be checked, they can be placed within the already prepared. All notions of a set and measure, quantity and relationship, causality and order can be exactly outlined, they always agree. However, this is radically changed when the moment of a person is added to the notion. As if something ungraspable, disturbing, even explosive entered the concept. The notions and measures are suddenly struck by a movement. They are no longer that certain. All of the categories need to be revised! ${ }^{11}$.

\footnotetext{
${ }^{6}$ Ibid., p. 81.

${ }^{7}$ Cf. ibid., p. 82.

${ }^{8}$ Ibid., p. 77.

9 Ibid., p. 78.

${ }^{10}$ Ibid., p. 78.

${ }^{11}$ Ibid., p. 83.
} 


\begin{tabular}{|c|c|c|}
\hline Individualism & Pluralism & Totalitarianism \\
\hline "A human is overly adult" & "Complexity of a person" & "A human is overly childish" \\
\hline $\begin{array}{l}\text { Fails before the phenomenon of } \\
\text { multitude, fragmentation }\end{array}$ & Mezotés & Great purge, uniformity \\
\hline $\begin{array}{l}\text { Mismanaged multitude - leads to } \\
\text { anarchy }\end{array}$ & As a personalistic virtue & Centralism - leads to tyranny \\
\hline Exposition to radicalisms & (fragile search for balance) & $\begin{array}{l}\text { "Great simplification" in contrast } \\
\text { to complexity of freedom }\end{array}$ \\
\hline
\end{tabular}

A metaphor of the "organic pluralism" is the category of home (oikos) that expresses care (solidarity), personality (a unique and loved You) and commitment (ethos of co-existence) at the same time. It provides both freedom (authenticity, identity) and safety.

\section{Con-versio from multitude}

Hanusian "organic pluralism" connects and integrates multitude (a human being as an individuum in plurality of those similar to him/her), which is its quantitative dimension, with organicness (a human being as a person, a human-in-relationship-with-others), which is its qualitative dimension ${ }^{12}$. Development of a person takes place by a gradual and purposeful interweaving of quantity with quality and this activity is called education. Education of an individuum to a person ${ }^{13}$ takes place predominantly in a family and afterwards, in broader interpersonal communities in which the basic plurality relationship, dialogue, is present ${ }^{14}$.

The term con-versio connects a movement, turnover, change (vertere) with the dimension of a community (the prefix con, similarly contained in the word com-unio, community). The emphasis on the prefix con- is implied by a community and dialogical approach of this change. The Czech philosopher Radim Palouš identifies particularly education with the process of conversion. In his work Čas výchovy (1991) [tr. Time of Education], he explains education as a turning point in the self-understanding of a human being and the resulting understanding of the world. "Education is techné tés periagogés, an event that through tearing out from everydayness reveals our everydayness as such a thus, it reveals hiddenness of the hidden, mysteriousness of the mysterious and eventually, subordination of the preordained"15. Palouš refers to Comenius's perception of education as emendatio rerum humanarum, as a correction of human things. According to Comenius, people live in chaos, disorder and sin, therefore, school is supposed to help them to correct their straying, to encourage

\footnotetext{
${ }_{12}$ Cf. J. Maritain, L'educazione al bivio, Editrice La Scuola, Brescia 1993, p. 22.

${ }^{13}$ L. Hanus, op.cit., p. 95.

${ }^{14}$ Cf. ibid., p. 113.

15 R. Palouš, Čas výchovy, SPN, Praha 1991, p. 34.
} 
them to a turning point A turning point, conversion, takes place in the direction from the fragmentary, the partial, the individual and the meaningless toward the whole, the truth of the entire life, the meaning. "Only when a human crosses the individual and the partial and understands them as such, then a real correction may occur. Therefore, the entire human life needs to be perceived as a training, as a school" 16 . Conversion of a human being is a fundamental element of education; the educated is situated in an event of a release from "sinking" into worrying self-provision and they are turned toward what is preordained to them as humans ${ }^{17}$. Similarly to the myth about a cave, the turning point of the imprisoned slave takes place in a painful manner - the educated is forced to turn around, rise, walk in the darkness, even if their senses and limbs defend themselves from this process in many ways. They do not find "conversion" for something pleasant - they are painfully led forth, up a steep path, to the exit of the cave. However, the very educatio (lead forth) needs to be preceded by their own conversio.

\section{Bibliography}

Buber M., Já a ty, Mladá fronta, Praha 1969.

Flores d'Arcais (ed.), Pedagogie personalistiche e/o pedagogia della persona, La Scuola, Brescia 1994.

Hanus L., Princíp pluralizmu, Lúč, Bratislava 1997.

Lechta V. (ed.), Základy inkluzivní pedagogiky, Portál, Praha 2010.

Lévinas E., Být pro druhého, Zvon, Praha 1997.

Maritain J., L’educazione al bivio, Editrice La Scuola, Brescia 1993

Milan G., Educare all'incontro. La pedagogia di Martin Buber, Città Nuova, Rím 2002. Palouš R., Čas výchovy, SPN, Praha 1991.

Patočka J., Péče o dusi, Oikoymenh, Praha 1996.

Platón, Obrana Sokratova, [in:] A. Bröstl, Aténsky lud proti občanovi Sokratovi, Kalligram, Bratislava 2006, pp. 53-88.

Poláková J., Filosofie dialogu, Ježek, Praha 1995.

Rajský A., Nihilistický kontext kultivácie mladého človeka. Filozoficko-etický pohlad, TUT/Veda, Trnava 2009.

Rajský A., Personalistické východiská pre teóriu kultivácie človeka, [in:] B. Kudláčová, S. Sztobryn (eds.), Kontexty filozofie výchovy v historickej a súčasnej perspektíve, Pedagogická fakulta Trnavskej univerzity v Trnave, Trnava 2011, pp. 73-88.

\footnotetext{
16 Ibid., p. 39.

${ }_{17}$ Cf. ibid., p. 61.
} 


\section{Ad unum vertere? Education as con-versio from multitude}

Abstract: The complexity and universal validity of knowing became a reason and aim of intellectual effort expressed in the notion philo-sophia. The advantages of universalism can be summarised into several elements: the concept of human nature, the ontological fundament of human dignity, and their ethical demands, regardless of individual differences. On the other hand, universalism hides within itself an ever-present germ of potential destructivity, when, in the name of the "universal truth," there occurs a factual and inhumane exclusion of certain individuals and groups from the community of those who "deserve" dignitas humana. Slovak philosopher of culture Ladislav Hanus in his work Principle of Pluralism defines "organic pluralism". Hanusian "organic pluralism" connects and integrates multitude, which is its quantitative dimension, with organicness, which is its qualitative dimension. The development of a person takes place by a gradual and purposeful interweaving of quantity with quality, and this activity is called education, or con-versio from multitude.

Keywords: universalism, unity versus plurality, polyphonic truth, Ladislav Hanus, organic pluralism, education as conversion

\footnotetext{
About the author: Andrej Rajský, ass. prof., PhD. - vice-dean for science and research; associate professor in ethics, Faculty of Education, Trnava University, Slovakia. He focuses on the field of philosophy of education and moral philosophy and finds challenges and motivations for philosophy of moral education in their intersection. A selection of his book publications includes the following: A person as an icon of mystery. Contribution to the personalistic anthropology (2007), The nihilistic context of cultivating a young person. Philosophical-ethical view (2009), European pedagogical thinking (from modernism to postmodernism to the present) (2012, co-editor), Man to man. To the sources of ethical education (2016, co-editor), Help to the Other on the road of virtue. On the Philosophical-Ethical Aspects of Prosociality (2018, co-editor).
}

The paper originated as an outcome of the project VEGA No. 1/0557/16. 


\title{
Trudne zachowania u dzieci w wieku przedszkolnym - nieprawidłowości w rozwoju psychoruchowym czy błędy w procesie wychowawczym?
}

\begin{abstract}
Streszczenie: W artykule zostały omówione wybrane aspekty związane z manifestowaniem trudnych zachowań przez dzieci w wieku przedszkolnym. Zachowania te mogą wynikać z pewnych nieprawidłowości w rozwoju psychoruchowym oraz błędów popełnianych przez dorosłych w procesie wychowawczym. Trudności w zachowaniu, choć często uciążliwe dla funkcjonowania samego dziecka oraz jego rodziców i nauczycieli, nie są niepełnosprawnościami. Pomimo że częściowo uwarunkowane są one biologicznie, w dużej mierze jednak zależne są od sposobu wychowywania. W artykule zostały zawarte wskazówki dla rodziców i nauczycieli, jak należy postępować z dziećmi, aby zminimalizować trudne zachowania oraz ograniczyć ryzyko ich wystąpienia. Udzielenie wczesnego wsparcia dziecku sprzyja lepszemu funkcjonowaniu w przyszłości, bo zapewnia bardziej harmonijny rozwój, ułatwia naukę, a w dorosłości zwiększa szanse na satysfakcjonujące życie w społeczeństwie.
\end{abstract}

Słowa kluczowe: trudne zachowania u dzieci w wieku przedszkolnym, zaburzenia dynamiki procesów nerwowych, błędy wychowawcze, wczesna interwencja

* Karolina Skarbek - dr nauk społecznych w dyscyplinie pedagogika, psycholog, absolwentka Uniwersytetu Warszawskiego. Pracuje jako adiunkt w Katedrze Pedagogiki Małego Dziecka Akademii Pedagogiki Specjalnej im. Marii Grzegorzewskiej w Warszawie. Prowadzi badania naukowe w zakresie uzdolnień matematycznych dzieci, prawidłowości procesu uczenia się, diagnozy dziecka. Ponadto pracuje jako psycholog w jednej $\mathrm{z}$ warszawskich poradni psychologiczno-pedagogicznych, gdzie zajmuje się diagnozą i terapią dzieci, wspieraniem rodziców, a także współpracuje z nauczycielami przedszkoli. 


\section{Wprowadzenie}

Obserwując zachowanie dzieci, zarówno podczas zajęć w przedszkolu, jak i w trakcie aktywności w domu rodzinnym, możemy zauważyć duże różnice w funkcjonowaniu w zakresie łatwości powstawania napięcia emocjonalnego, zdolności do kontroli emocji, odporności na znużenie, ruchliwości, wydajności pracy, koncentracji uwagi. Te aspekty zachowania są ściśle powiązane z dynamiką procesów nerwowych, występują w tym zakresie duże różnice indywidualne między dziećmi ${ }^{1}$.

Z tych też względów w trafnej ocenie rozwoju dziecka należy zawsze uwzględniać pewien margines tolerancji wobec stwierdzanych odchyleń od przyjętych norm, ponieważ dzieci różnią się między sobą tempem rozwoju w różnych sferach. Wcale nie do rzadkości należą sytuacje, w których dziecko w danym momencie odbiega od poziomu rozwoju swoich rówieśników, ale różnice te jest w stanie nadrobić w niedługim czasie. W przypadku niewielkich odchyleń od normy mówimy właśnie o różnicach indywidualnych ${ }^{2}$.

W artykule chciałabym skoncentrować swoją uwagę na wybranych aspektach związanych $\mathrm{z}$ manifestowaniem trudnych zachowań przez dzieci $\mathrm{w}$ wieku przedszkolnym. Zachowania te mogą wynikać z pewnych nieprawidłowości w rozwoju psychoruchowym lub/i błędów wychowawczy popełnianych przez samych dorosłych. Bardzo często pomiędzy przyczynami uwarunkowanymi biologicznie i społecznie występuje sprzężenie zwrotne. Zjednej strony błędy wychowawcze w postępowaniu z dzieckiem mogą utrudniać jego rozwój, a z drugiej strony niewłaściwa praca $\mathrm{z}$ dzieckiem $\mathrm{z}$ nieprawidłowościami w rozwoju psychoruchowym może te trudności nie tylko nasilać, ale także generować nowe. Trudności w zachowaniu, choć często uciążliwe dla funkcjonowania samego dziecka i pracujących z nim rodziców i nauczycieli, nie są niepełnosprawnościami, charakteryzującymi się istotnymi odchyleniami od norm rozwojowych ${ }^{3}$.

${ }^{1}$ Związane są one z cechami układu nerwowego, uwarunkowanymi w dużej mierze biologicznie. Z tego jednak względu, że układ nerwowy dziecka nie jest całkiem dojrzały ani strukturalnie, ani funkcjonalnie, duży wpływ na jego ukształtowanie ma wychowanie i warunki życia. Zob. A. Jaczewski, Biologiczne i medyczne podstawy rozwoju i wychowania, Wydawnictwo Akademickie „Żak”, Warszawa 2005; B. Woynarowska, A. Kowalewska, Z. Izdebski, K. Komosińska, Biomedyczne podstawy kształcenia i wychowania, Wydawnictwo PWN, Warszawa 2010; H. Spionek, Problemy rozwojowe i wychowawcze wczesnego dzieciństwa, Wydawnictwo Książka i Wiedza, Warszawa 1972.

2 J. Głodkowska, Model kształcenia uczniów ze specjalnymi potrzebami edukacyjnymi - różnice nie moga dzielić, [w:] Podniesienie efektywności kształcenia uczniów ze specjalnymi potrzebami edukacyjnymi. Materiały dla nauczycieli, część I, Ministerstwo Edukacji Narodowej, Warszawa 2010, s. 50.

${ }^{3}$ Czytelników zainteresowanych wiedzą na temat ciężkich zaburzeń rozwojowych odsyłam do bogatej literatury pedagogicznej i psychologicznej w tym zakresie. Zob. A. Twardowski, Wczesne wspomaganie rozwoju dzieci z niepełnosprawnościami w środowisku rodzinnym, Wydawnictwo Naukowe Uniwersytetu Adama Mickiewicza, Poznań 2012; J. Cieszyńska, M. Korendo, Wczesna interwencja terapeutyczna. Stymulacja rozwoju dziecka. Od noworodka do 6 roku życia, Wydawnictwo Edukacyjne, Kraków 2008; W. i J. Pileccy (red.), Stymulacja psychoruchowego rozwoju dzieci 


\section{"Głód ruchowy" czy już zaburzenia w dynamice procesów nerwowych?}

Zjawiskiem rozwojowym u małych dzieci w pewnych granicach jest słabość procesów nerwowych, szczególnie duża ruchliwość i mały stopień zrównoważenia, co związane jest z niepełną jeszcze dojrzałością układu nerwowego. Wraz z wiekiem dziecka powinniśmy obserwować, jak wzrasta siła procesów nerwowych, stabilizuje się ich równowaga i ruchliwość. Powinno to mieć swoje odzwierciedlenie w większej wydolności, w lepszym panowaniu nad emocjami. Gdy jednak wraz z rozwojem dziecko jest nadal bardzo męczliwe, apatyczne, bierne albo nadmiernie pobudzone, impulsywne, mało wydolne, wzrasta labilność emocjonalna, czyli chwiejność nastrojów, łatwość wpadania w skrajne emocje, jest to wtedy sygnałem nieprawidłowości w zakresie dynamiki procesów nerwowych. Często jednak trudno jednoznacznie wyznaczyć wyraźną granicę między szeroko rozumianą normą a stanem patologicznym ${ }^{4}$.

Dzieje się tak dlatego, że dzieci mają szczególnie wzmożone zapotrzebowanie na aktywność ruchową, a zaspokojenie tej potrzeby jest warunkiem ich prawidłowego rozwoju. Najbardziej znamienną cechą obserwowaną u dziecka przedszkolnego w zakresie rozwoju motorycznego jest duża ruchliwość, potrzeba działania, określana mianem „głodu ruchowego”. Towarzyszy jej jednocześnie obniżona wytrwałość, krótka koncentracja na jednej czynności, zmienność zainteresowań. Wiąże się to ze specyfiką funkcjonowania układu nerwowego, charakteryzującą się przewagą procesów pobudzenia nad hamowaniem ${ }^{5}$. Należy jednak zaznaczyć, że zjawisko głodu ruchowego jest prawidłowym przejawem w rozwoju małego dziecka, a tymczasem często interpretowane jest jako niepokojące, a co gorsza, w niektórych przypadkach mylone jest $\mathrm{z}$ nadpobudliwością psychoruchową.

Oczywiście, w zachowaniu przedszkolaków mogą ujawniać się także poważne zakłócenia równowagi procesów nerwowych, należy jednak wtedy być bardzo ostrożnym w ocenie nieprawidłowości, a ostateczną diagnozę pozostawić odpowiednim specjalistom. W zakresie zakłócenia równowagi procesów nerwowych możemy mieć do czynienia z przewagą pobudzania nad hamowaniem i obserwujemy to zjawisko u dzieci nadpobudliwych lub odwrotnie, występuje przewaga hamowania nad pobudzaniem, co prowadzi do zahamowania psychoruchowego ${ }^{6}$.

Nadpobudliwość psychoruchowa w literaturze specjalistycznej określana jest jako zespół nadpobudliwości psychoruchowej z zaburzeniami koncentracji uwagi

o obniżonej sprawności umysłowej, Wydawnictwo Naukowe Akademii Pedagogicznej, Kraków 2003; P.C. Kendall, Zaburzenia okresu dzieciństwa i adolescencji, Gdańskie Wydawnictwo Psychologiczne, Gdańsk 2004.

${ }^{4}$ H. Spionek, dz. cyt., s. 150.

${ }^{5}$ R. Przewęda, Rozwój motoryczny, [w:] A. Jaczewski (red.), dz. cyt.

${ }^{6}$ H. Spionek, dz. cyt. 
(w skrócie ADHD) lub zespół hiperkinetyczny7. Jest to zaburzenie neurobiologiczne, rozpoznawane u 3-8\% populacji u dzieci i młodzieży. Głównymi objawami nadpobudliwości psychoruchowej, wynikającymi z nadmiernej pobudliwość układu nerwowego są: nadaktywność ruchowa, impulsywność, wzmożona pobudliwość emocjonalna i/lub specyficzne zaburzenia w sferze poznawczej, szczególnie w zakresie koncentracji uwagi ${ }^{8}$.

Z tych też względów dzieci nadpobudliwe psychoruchowo pozostają niemalże w ciągłym ruchu - biegają, skaczą, opuszczają miejsce przy stoliku w trakcie wykonywania zadań, szybko zmieniają aktywność, wielokrotnie nie kończąc jednej czynności zaczynają kolejną. Gdy muszą pozostawać w pozycji statycznej, często pojawiają się takie zachowania, jak wiercenie się na krześle, nerwowe ruchy rękoma lub stopami, obgryzanie paznokci itp. Dzieci te nie są w stanie dłużej skoncentrować się na jednej czynności, mają wzmożony odruch orientacyjny, często i łatwo ulegają rozproszeniu przez nieistotne bodźce wzrokowe lub dźwiękowe, mają trudności w spostrzeganiu i zapamiętywaniu, przejawiają niechęć do zadań wymagających dłuższego wysiłku umysłowego, mają trudności ze zorganizowaniem pracy czy zabawy, gubią swoje rzeczy osobiste. Ponadto dzieci nadpobudliwe są impulsywne emocjonalnie, niecierpliwe, pochopnie i pobieżnie wykonują zadania, zbyt szybko udzielają nieprzemyślanych odpowiedzi, nie potrafią czekać na swoją kolej.

Odnośnie rozpoznania nadpobudliwości psychoruchowej należy wyraźnie podkreślić, że zaburzenie to diagnozuje wyłącznie psychiatra, natomiast nauczyciel może obserwować jego przejawy w zachowaniu dziecka. Zauważywszy niepokojące zachowania, nauczyciel powinien wskazać rodzicom konieczność konsultacji specjalistycznej. Należy również pamiętać o różnicowaniu zaburzenia nadpobudliwości psychoruchowej od trudności wychowawczych wynikających z niewłaściwych oddziaływań środowiskowych ${ }^{10}$.

Natomiast w przypadku dzieci zahamowanych psychoruchowo mamy do czynienia z zahamowaniem nie tylko reakcji ruchowych, ale także słownych i mimicznych, przy jednoczesnym występowaniu wzmożonych reakcji emocjonalnych i wegetatywnych. Może wytworzyć się u tych dzieci postawa lękowa, skutkująca wycofywaniem się $\mathrm{w}$ niesprzyjających warunkach, przy nadmiernych i nieadekwatnych wymaga-

${ }^{7}$ W zależności, według której klasyfikacji chorób będzie stawiana diagnoza - Międzynarodowej Klasyfikacji Chorób i Zaburzeń (ICD-10) czy Amerykańskiej Klasyfikacji Zaburzeń Psychicznych (DSM-V). Zob. T. Wolańczyk, A. Kołakowski, M. Skotnicka, Nadpobudliwość psychoruchowa u dzieci, Wydawnictwo BiFolium, Lublin 1999. W literaturze wyróżnia się trzy główne podtypy zespołu nadpobudliwości: typ z przewagą zaburzeń koncentracji uwagi, typ z przewagą nadpobudliwości, typ mieszany.

8 A. Popielarska, M. Popielarska, Psychiatria wieku rozwojowego, PZWL, Warszawa 2000, s. 109.

${ }_{9}$ G. Rudkowska, Uczniowie z trudnościami w rozwoju emocjonalno-społecznym, [w:] W. Pilecka, G. Rudkowska, L. Wrona (red.), Podstawy psychologii. Podręcznik dla studentów kierunków nauczycielskich, Wydawnictwo Naukowe Akademii Pedagogicznej, Kraków 2005, s. 391-393.

${ }_{10}$ Zob. T. Wolańczyk i in., dz. cyt. 
niach wychowawczych. Dzieci zahamowane psychoruchowo są mało ruchliwe, czasem wręcz spowolniałe i bierne. Wymagają dłuższego czasu na zastanowienie się. Często przyjmują rolę obserwatorów. Słabo reagują na zmiany, nowe sytuacje. Nie wykazują raczej inicjatywy, skłonne są do naśladowania innych. Ich reakcje emocjonalne na zewnątrz są mało żywiołowe, ekspresyjne ${ }^{11}$.

Podsumowując, w stosunku do dzieci odznaczających się zaburzeniami dynamiki procesów nerwowych, zarówno tych nadpobudliwych, jak i zahamowanych psychoruchowo popełnia się wiele błędów wychowawczych, co może doprowadzać do wtórnych zaburzeń w sferze emocjonalno-społecznej. Dzieci te wymagają wyjątkowo konsekwentnego, spokojnego i zrównoważonego postępowania wychowawczego.

\section{Wskazówki dla rodziców i nauczycieli w postępowaniu z dziećmi przejawiającymi zaburzenia dynamiki procesów nerwowych}

Dzieciom zahamowanym psychoruchowo-biernym, nieśmiałym $\mathrm{z}$ tendencją do wycofywania się należy:

- Dać „emocjonalną przestrzeń” do wykazania się inicjatywą, działaniem, tzn. nie zmuszać ich za wszelką cenę do aktywności, nie porównywać z innymi dziećmi, raczej łagodnie zachęcać niż natarczywie nalegać, aby brały udział w zabawach grupowych. Proponować zabawy polegające na wcielaniu się w role, stosować techniki dramowe, które pozwolą odreagować emocje. Warto modelować właściwe zachowania przy udziale rówieśników.

- Stwarzać sytuacje, w których dzieci te doświadczą pozytywnych emocji, związanych z powodzeniem, aprobatą nauczyciela i rówieśników.

- Warto takie zahamowane dzieci delikatnie, w naturalny sposób włączać w podejmowanie różnych zadań podczas rutynowych czynności dnia codziennego w przedszkolu. Początkowo proponować takie sytuacje, które gwarantują powodzenie. W razie porażki należy udzielić pomocy bez wyrażania ocen negatywnych, bez komentowania na forum grupy.

- Wyznaczać drobne zadania, które małymi kroczkami będą pomagały im przełamywać wycofanie, np. warto posyłać je do drugiej grupy, aby pożyczyły jakieś materiały papiernicze, potrzebne do wykonania pracy plastycznej.

- Często proponować różne techniki relaksacyjne, pracy z ciałem, pomagające rozluźnić nadmierne napięcie mięśniowe; wyrazić siebie poprzez ruch.

${ }^{11}$ H. Nartowska, Zestawienie charakterystycznych objawów zaburzeń i zabiegów wyrównawczych, [w:] M. Dunin-Wąsowicz (red.), Vademecum nauczyciela sześciolatków, Wydawnictwa Szkolne i Pedagogiczne, Warszawa 1980, s. 420-428. 
- Proponować bajkoterapię, dzięki której będzie można delikatnie poruszyć różne nurtujące je problemy, a także w bezpieczny sposób pokazać, jak można sobie z nimi radzić w codziennym życiu.

Natomiast dzieci nadpobudliwe łatwo zniechęcają do siebie otoczenie ze względu na wzmożoną ruchliwość, impulsywność w działaniu, upór, łamanie zasad. Często ich postępowanie postrzegane jest jako złośliwe, umyślne, a nie przez pryzmat nieprawidłowości w działaniu ich układu nerwowego. Zamiast nieuzasadnionych pretensji, surowych upomnień, kar za niewykonanie polecenia należy dostrzegać trudności dziecka, starać się zrozumieć genezę tego zjawiska. Takie dziecko często ma dużo chęci, ale nie starcza mu wytrwałości ${ }^{12}$.

Dzieciom nadpobudliwym psychoruchowo należy ${ }^{13}$ :

- Zaspokoić potrzebę wzmożonego ruchu poprzez organizowanie zabaw ruchowych odpowiednich dla wieku, takich jak: igraszki z piłką, ćwiczenia na trampolinie, turlanie się, skakanie na różne sposoby, a poza placówką pływanie, jazda na rowerze, hulajnodze, łyżworolkach itp.

- Organizować zabawy w atrakcyjny sposób, aby początkowo osoba dorosła kierowała zabawą, a potem stopniowo zwiększał się zakres samodzielności wykonywanych przez dziecko czynności; wydłużając czas trwania zadań.

- Maksymalnie ograniczyć liczbę rozpraszających bodźców w sali, np. pochować zbędne przedmioty ze stolików, zamknąć okno, jeśli pojawia się za nim hałas itp. Dziecko powinno siedzieć daleko od okna i blisko nauczyciela.

- Wyznaczać funkcje pomocników nauczyciela, przydzielać im różne zadania, które będą dla nich przerywnikami w zajęciach, np. rozdawanie wszystkim dzieciom kartek. Ważne, aby wyznaczając drobne obowiązki, dopilnowywać, żeby dzieci się z nich wywiązywały.

- Stawiać wymagania, które dzieci są w stanie spełnić; wyznaczone zadania nie mogą być ani za łatwe, ani za trudne.

- Powtarzać polecenia i wskazówki, utrzymując przy tym z dzieckiem kontakt wzrokowy. Polecenia i instrukcje muszą być krótkie.

- Duże zadania dzielić na mniejsze sekwencje. Chwalić po każdym wykonanym etapie.

- Sprawdzać od razu każde zrobione przez dziecko zadanie.

- Większe fragmenty zajęć podsumowywać, stosując obrazki, rebusy.

- Wprowadzać krótkie przerwy podczas zajęć, najlepiej w formie aktywności ruchowej.

${ }^{12}$ D. Siemek, Problemy wychowawcze wieku przedszkolnego, Instytut Wydawniczy Związków Zawodowych, Warszawa 1987.

${ }^{13}$ Niniejsze wskazówki zostały opracowane na podstawie następujących publikacji: A. Kołakowski, A. Pisula, Sposób na trudne dziecko, Gdańskie Wydawnictwo Psychologiczne, Sopot 2012; D. Siemek, dz. cyt. 
- Pozwolić na wykonywanie ruchów, które nie mają negatywnego wpływu na wykonanie zadania, np. pozwalamy na machanie nogą przy słuchaniu bajki itp.

- Pokazać, w jaki sposób dziecko może rozładować napiętą sytuację, np. dając polecenie - narysuj swoją złość.

- Należy nie szczędzić pochwał, jeśli dziecko dobrze postępuje; ono musi czuć, że jest otoczone opieką, że mimo trudności, jakie sprawia, jest kochane. Straszenie i grożenie może wywołać reakcje nerwicowe lub agresywne zachowania.

- Stworzyć regulamin, wprowadzić jasno określone zasady zachowania; kodeks musi być zapisany w pozytywnej formie (nie za pomocą zakazów) i umieszczony w widocznym miejscu w sali. Powinien on zawierać obrazki, które będą ilustrowały obowiązujące normy.

- Pokazać, że nauczyciel ma pozytywne nastawienie, docenia pracę dzieci i ma świadomość, że ich zachowanie nie wynika z nieposłuszeństwa i złośliwości ${ }^{14}$.

Podsumowując, w przypadku dzieci, u których zdiagnozowano zaburzenia w dynamice procesów nerwowych, należy podejmować takie działania zarówno w placówce edukacyjnej, jak i w środowisku rodzinnym, które będą nie tylko pozwalały wypracować strategie kompensacyjne, łagodzące skutki tych zaburzeń w codziennym funkcjonowaniu, ale będą także przeciwdziałać wytworzeniu się nieprawidłowych wzorców zachowań i wtórnych problemów emocjonalnych.

\section{Trudności wychowawcze}

Dziecko w wieku przedszkolnym do pełnego rozwoju potrzebuje nie tylko najbliższej rodziny, ale także rówieśników oraz doświadczeń w szerszej grupie społecznej, aby nauczyć się samokontroli, współpracy i współżycia z innymi, radzenia sobie z porażką.

Uczucia dziecka przedszkolnego charakteryzuje zmienność, przedszkolak łatwo ulega nastrojom, emocje szybko się zmieniają (tzw. labilność emocjonalna). Sfera emocjonalno-społeczna powinna wraz w wiekiem i pod wpływem wychowania stopniowo dojrzewać, objawiać się to powinno w lepszej kontroli emocji, dopasowywaniu postępowania do obowiązujących norm społecznych i moralnych ${ }^{15}$.

W rozwoju emocjonalno-społecznym dziecka bardzo dużą rolę odgrywają jego najbliżsi - rodzice, rodzeństwo, dziadkowie, ale także nauczyciele, których dziecko obserwuje i naśladuje. Tak utrwalają się wzorce postepowania, niezależnie od tego, jakich obserwowanych zachowań dotyczą - pożądanych czy nieprawidłowych. Dzieje się tak dlatego, że dzieci z jednej strony są dobrymi obserwatorami, a z drugiej strony jednocześnie brak im powściągliwości, umiejętności przewidywania skutków

${ }^{14}$ F.J. O’regan, Jak pracować $z$ dziećmi o specjalnych potrzebach edukacyjnych, Wydawnictwo Liber, Warszawa 2005.

${ }_{15}$ D. Siemek, dz. cyt. 
własnych działań. Niejednokrotnie dzieci, które sprawiają trudności wychowawcze, przyswoiły sobie formy zachowania niepożądanego drogą naśladownictwa, obserwując dorosłych nieprawidłowo odnoszących się do dziecka ${ }^{16}$. Rodzic, nauczyciel musi być dla dziecka wzorem dobrego zachowania, powinien pokazywać dziecku, jakie postępowanie uważa za prawidłowe, a jakiego nie pochwala, ale nie moralizowaniem, karceniem, a swoją postawą, sposobem funkcjonowania i komunikowania się w codziennym życiu.

Należy pamiętać, że problemy z zachowaniem nie są tym samym, co problemy z dzieckiem. Przyczyny niewłaściwego zachowania mogą być różne. Czynniki ryzyka, które mogą niekorzystnie wpływać na kształtowanie się niepokojących zachowań u dzieci mogą być związane z samym dzieckiem, jego konstrukcją psychofizyczną (uwarunkowany genetycznie trudny temperament wzmaga impulsywność, łatwe napady złości, utrudnia kontrolę emocji), z rodziną dziecka (wynikać z konfliktów między rodzicami, z rozbieżności w poglądach na temat wychowania dziecka, z chorób psychicznych rodziców, uzależnień, kłopotów finansowych) i z niewłaściwymi postawami wychowawczymi rodziców (stosowanie zbyt surowych lub pobłażliwych metod wychowawczych, niewłaściwych oczekiwań wobec możliwości rozwojowych dziecka, z braku odpowiednich reakcji rodziców na sygnały wysyłane przez dziecko, z nieokazywania dziecku uwagi, ciepła, miłości $)^{17}$.

Te wszystkie czynniki mogą powodować, że nauczyciele często mają w swojej pracy do czynienia $z$ dziećmi niedojrzałymi pod względem emocjonalno-społecznym, które nie rozwinęły swoich umiejętności w tej sferze na takim samym poziomie, co ich rówieśnicy. Mają one niską samoocenę i nie potrafią nawiązać dobrych relacji $\mathrm{z}$ kolegami. Wynika to z niezaspokojenia potrzeb tych dzieci, które dorastają w skonfliktowanej rodzinie, niewydolnej wychowawczo czy w dysfunkcjonalnym środowisku edukacyjnym ${ }^{18}$.

Dzieci, które nie są chwalone, nie okazuje się im miłości, ciepła, zrozumienia, nie wyznacza się im jasno granic w wychowaniu, nie tłumaczy, dlaczego pewne ich zachowania nie są akceptowane społecznie, wyrastają na osoby zimne uczuciowo, niewrażliwe na krzywdę drugiego człowieka, egoistyczne ${ }^{19}$.

Zatem proces wychowawczy może rozwinąć cechy pożądane dla dalszego rozwoju dziecka i korzystne społecznie, jak też cechy niepożądane mogą dodatkowo ulec pogłębieniu wskutek wadliwego wychowania ${ }^{20}$.

Błędy wychowawcze popełniane przez najbliższe otoczenie mogą prowadzić do niedojrzałości w sferze emocjonalno-społecznej u dzieci kończących przedszkole.

16 Tamże.

17 A. Kołakowski, A. Pisula, dz. cyt.

18 J. Thompson, Specjalne potrzeby edukacyjne, Państwowe Wydawnictwo Naukowe, Warszawa 1987.

19 D. Siemek, dz. cyt.

${ }^{20}$ H. Nartowska, dz. cyt. 
Przyczyniać się to tego mogą konflikty w rodzinach, ale także, paradoksalnie, nadmierne ochranianie dziecka. Wyręczanie dziecka, ochrona przed nawet najmniejszą przykrością powoduje, że dziecko staje się bierne, brak mu inicjatywy, niechętnie podejmuje jakiekolwiek wyzwania, wyrabia o sobie fałszywe przekonanie, o swoich możliwościach i umiejętnościach ${ }^{21}$.

Dzieciom charakteryzującym się niedojrzałością emocjonalno-społeczną trudno funkcjonować w grupie rówieśniczej. Zachowują się one w sposób charakterystyczny dla dzieci młodszych, próbują narzucać swoje zdanie, są skupione jedynie na własnych potrzebach, mają trudności z kontrolą emocji - są płaczliwe, często wpadają w złość nieadekwatnie do zaistniałej sytuacji. Chcą dominować lub są nadmiernie nieśmiałe, wycofane, co powoduje, że w obu przypadkach mają trudności w nawiązaniu wspólnej zabawy z przestrzeganiem ustalonych reguł. Często są mało wytrwałe, nie wywiązują się z powierzonych im zadań, nie wykonują poleceń, nadmiernie łamią ustalone zasady ${ }^{22}$.

Wszystkie dzieci przeżywają w różnych sytuacjach uczucia gniewu, złości, niezadowolenia, zdarza się, że dokuczają innym, chcą postawić na swoim używając siły, złamią obowiązujące zasady. Jeżeli takie zachowania zdarzają się incydentalnie, są czymś rozwojowym. Niepokojące natomiast są sytuacje, gdy dzieci są cały czas agresywne, niepodporządkowane. Prawdopodobnie wobec tych dzieci popełniono wiele błędów wychowawczych - dorośli stosowali wobec nich niekonstruktywne metody wychowawcze, polegające na wprowadzaniu bezwzględnych ograniczeń, nakazów, nieuwzględniających ich możliwości psychofizycznych. Brak cierpliwości w reakcjach dorosłych, gorączkowe tłumaczenie, moralizowanie i pouczanie na niewiele się zda w kształtowaniu właściwych reakcji emocjonalnych, akceptowanych społecznie. Dzieciom o wiele łatwiej będzie podporządkować się rodzicom i nauczycielom, ich nakazom, jeśli będą one sformułowane w pozytywny sposób, akceptujący postawę dziecka. Polecenia formułowane w taki sposób nazywane są afirmującymi, są bardziej skuteczne, ponieważ nie wyzwalają w dziecku przekory, a zachęcają go współdziałania, budzą zaufanie do dorosłych. Takie polecenia czy zakazy sformułowane w pozytywny sposób („na tak”) wymagają od dorosłych przeanalizowania sytuacji wychowawczych, podjęcia próby postawienia się w pozycji dziecka, przemyślenia motywów ich wydawania. Jeśli w procesie wychowawczym dorośli narzucają swoje poglądy, posługując się sztywnym systemem nakazów, zakazów, kar, to bardzo często przynosi to skutki odwrotne od zamierzonych. Zamiast przygotowania dziecka do samodzielności życiowej, pełnienia określonych ról społecznych, doprowadza to do reakcji nerwicowych u dzieci, buntu, przekory, a przymusowe posłuszeństwo okazuje się tylko chwilowe, a później przekształca się w opór i agresję ${ }^{23}$.

\footnotetext{
21 D. Siemek, dz. cyt.

22 Tamże.

23 Tamże.
} 
Analizując zachowania dziecka, warto rozważyć, z jakim rodzajem zachowań mamy do czynienia, czy są to jednie tak zwane „zachowania drażniące”, czy „zachowania niepożądane”, a może mamy do czynienia już z zachowaniami, które są objawami zaburzenia ${ }^{24}$. Taka wstępna analiza pozwoli określić sposób, w jaki nauczyciel i rodzic powinni interweniować - czy wystarczy, że sam nauczyciel podejmie pracę z dzieckiem podczas pobytu w przedszkolu, czy rodzice będą w stanie skutecznie pracować $\mathrm{z}$ dzieckiem $\mathrm{w}$ domu, a może niezbędna będzie konsultacja u specjalisty psychologa, a nawet psychiatry, którzy pomogą określić, czy zgłaszane zachowanie jest objawem zaburzenia, choroby dziecka, czy wynika raczej z popełnionych błędów wychowawczych ${ }^{25}$.

Oceniając zachowanie, zwłaszcza małych dzieci, należy pamiętać, że trudno jednoznacznie zdefiniować zachowania problemowe, określić ostre zakresy znaczeniowe, pomiędzy typowymi trudnościami rozwojowymi dla danego wieku a już zaburzeniami. Zachowanie należy spostrzegać jako problemowe w sytuacji, gdy jego natężenie, częstotliwość, czas utrzymywania się i następstwa znacząco odbiegają od zachowań rówieśników. Ponadto niepokojące zachowanie dziecka nie zmienia się w czasie, nie znika, a wręcz przeciwnie, jego symptomy nasilają się, są niezrozumiałe i dziwaczne dla otoczenia. Na początku warto sobie dać czas na podjęcie próby samodzielnego poradzenia sobie $\mathrm{z}$ problemem, natomiast, gdy pomimo podjęcia różnych działań nie zauważamy poprawy, warto skorzystać z pomocy specjalisty ${ }^{26}$.

\section{Wskazówki dla nauczycieli i rodziców - jak postępować, aby wyeliminować lub zminimalizować trudne zachowania u dzieci ${ }^{27}$}

- Zanim nauczyciele, rodzice zaczną działać wychowawczo, powinni szczegółowo przeanalizować aktualną sytuację dziecka, sporządzić listę problemo-

${ }^{24}$ A. Kołakowski i A. Pisula, autorzy książki, pt. Sposób na trudne dziecko piszą, że w przypadku kłopotów z dzieckiem warto zastanowić się nad trzema rodzajami zachowań: 1) zachowania drażniące - to zachowania, które są adekwatne do wieku, ale drażnią dorosłych, bo wymagają od nich większego wysiłku, zaangażowania w opiekę, a czasem wynikają ze zbyt wygórowanych wymagań względem dziecka; 2) zachowania niepożądane - to takie, które są nieodpowiednie dla wieku i poziomu rozwoju dziecka; mogą być zwiastunem poważniejszych problemów w zachowaniu czy rozwoju, często są uciążliwe nie tylko dla opiekunów, ale także samego dziecka; 3) zaburzenia - różne niepożądane zachowania dziecka, które wpływają ujemnie na funkcjonowanie dziecka oraz jego otoczenia i trwają co najmniej kilka miesięcy. Zob. A. Kołakowski, A. Pisula, dz. cyt.

${ }^{25}$ Tamże.

${ }^{26}$ Tamże.

${ }^{27}$ Niniejsze wskazówki zostały opracowane na podstawie następujących publikacji: A. Faber, E. Mazlish, Jak mówić, żeby dzieci nas stuchały, jak słuchać, żeby dzieci do nas mówiły, Media Rodzina, Poznań 2001; T. Gordon, Wychowanie bez porażek, Instytut Wydawniczy PAX, Warszawa 2003; J. Sakowska, Szkoła dla rodziców i wychowawców, Wydawnictwo CMPP-P MEN, Warszawa 
wych zachowań, najlepiej od razu określić uciążliwość każdego zachowania, jeżeli występuje ich więcej w zachowaniu dziecka. Do bieżącej pracy początkowo należy wybrać jedno zachowanie, dokonać jego analizy, co je wywołuje, jaki ma przebieg, jak długo trwa oraz jakie są jego konsekwencje dla dziecka i najbliższego otoczenia. Dopiero po takiej analizie możemy przystąpić do zaplanowania interwencji, wybrania odpowiednich metod wygaszających niepożądane zachowanie i wzmacniających zachowanie oczekiwane. W zaplanowaniu i przeprowadzeniu interwencji niezwykle ważna jest współpraca na linii nauczyciel-rodzic, dopiero zaangażowanie najbliższych osób dziecku zwiększa szanse powodzenia w procesie wychowawczym ${ }^{28}$.

- Jeśli rodzice, nauczyciele chcą zapobiegać pojawianiu się niepożądanych zachowań czy wyeliminować już istniejące trudne zachowania, mogą posłużyć się różnymi metodami behawioralnymi, tj. chwalenie, odwrócenie uwagi, skuteczne wydawanie poleceń, wprowadzenie zasad, wyciąganie konsekwencji ${ }^{29}$. Gdy chcemy wyeliminować zachowanie niepożądane, to w jego miejsce musimy wprowadzić inne, nowe, pozytywne, ale i atrakcyjne dla dziecka zachowanie ${ }^{30}$.

- Dorośli powinni wzmacniać pozytywne zachowania, stosując technikę modelowania (zachowywać się w sposób, jakiego oczekują od dziecka), ponieważ dzieci intencjonalnie czy też mimowolnie chętnie ich naśladują. Kiedy pozytywnych wzmocnień jest za mało, dziecko może zachowywać się destrukcyjnie. Ciągłe wzmocnienia negatywne z czasem podważają zaufanie i szacunek dla samego siebie, na skutek czego dziecko może wykazywać przejawy trudności emocjonalnych, np. unikać angażowania się w działania ${ }^{31}$.

- Ważne jest, aby wprowadzić jasno określone zasady i konsekwencje - dzięki temu różne sytuacje będą dla dziecka bardziej przewidywalne. Dziecko będzie wiedziało, czego się spodziewać, gdy zrobi coś nieakceptowanego. Formułując określone zasady, należy pamiętać, aby były one sformułowane krótko, w konotacji pozytywnej, dobrze, gdy dodatkowo zilustrowane są obrazkami. Warto je spisać w formie kodeksu postepowania ${ }^{32}$.

- Kolejnym krokiem jest konsekwentne egzekwowanie ustalonych zasad. W konkretnej sytuacji wychowawczej należy: podejść do dziecka, skoncentrować jego uwagę na sobie (spojrzenie w oczy, lekki dotyk), przypomnieć zasadę

1999; A. Kwaśny, M. Trąbińska-Haduch, Być mamą, materiały szkoleniowe, Fundacja Dzieci Niczyje, Warszawa 2001; A. Kołakowski, A. Pisula, dz. cyt.

${ }^{28}$ A. Kołakowski, A. Pisula, dz. cyt.

${ }^{29}$ Czytelnik więcej informacji o każdej z wymienionych metod znajdzie w książce A. Kołakowski, A. Pisula, dz. cyt., s. 58.

${ }^{30}$ Tamże.

${ }^{31}$ J. Thompson, Specjalne potrzeby edukacyjne, Wydawnictwo Naukowe PWN, Warszawa 2013, s. 41.

32 A. Kwaśny, M. Trąbińska-Haduch, dz. cyt. 
w krótkich słowach, poprosić dziecko o jej powtórzenie, a następnie pozostać przy dziecku, tak długo, aż zastosuje się do tej zasady.

- Stosowanie surowych kar jest nieskuteczne w dłużej perspektywie wychowawczej. Dorośli mylnie są przekonani, że kara powinna być dotkliwa, po to by w przyszłości uniknąć powtórzenia się sytuacji, która spowodowała karę. Stosując jednak karę, dorośli kierują się bezsilnością. Kara, która jest nieadekwatna do zachowania dziecka, nie wynika logicznie z zachowania dziecka, jest przez nie niezrozumiała, powoduje w nim poczucie krzywdy. Kara często przybiera formy krzywdzące dziecko, rodzi gniew i chęć odwetu, nie zmienia to w pozytywny sposób, trwale zachowania dziecka ${ }^{33}$.

- Należy stosować konsekwencje zamiast kar. Konsekwencje występują zaraz po zachowaniu, a nawet jeśli są odroczone w czasie, nadal są logicznie związane z zachowaniem. Jeśli dziecko powtarza nieakceptowane zachowanie, łamie ustalone zasady, powinno być uprzedzone o konsekwencji, jak go spotka, jeśli nie zmieni swojego postępowania. Konsekwencje powinny być adekwatne do wieku i możliwości dziecka, a także odpowiednie do rodzaju przewinienia, aby dziecko było w stanie zrozumieć związek między swoim zachowaniem a konsekwencją - w ten sposób uczy się, jakie zachowania warto podejmować, a $z$ jakich zrezygnować, bo są nieakceptowalne ${ }^{34}$.

- Wyznaczanie konsekwencji jest długotrwałym procesem. Zdarza się, że dorosły będzie musiał wielokrotnie wyciągać dane konsekwencje, żeby dziecko nauczyło się tego, czego się od niego oczekuje. Warto pamiętać, że gdy chcemy, żeby w zachowaniu dziecka zaszła zmiana, trzeba stosować daną metodę przynajmniej około dwóch tygodni, a potem cały czas ją konsekwentnie wzmacniać ${ }^{35}$.

- Zamiast karania warto zastosować następujący sposób postępowania. Krok 1: Wyraź swoje uczucia, nie atakując charakteru dziecka. Zawsze zaznaczaj, że nie podoba ci się zachowanie dziecka, a nie ono samo. Mów dziecku, jakie zachowania ci się nie podobają i podawaj przyczyny. Krok 2: Określ jasno swoje oczekiwania, czyli powiedz konkretnie, co dziecko ma zrobić. Krok 3: Wskaż dziecku, jak może naprawić przewinienie. Krok 5: Zaproponuj wybór. Wskaż dziecku co najmniej dwa możliwe sposoby zachowania się i jakie to będzie miało skutki. Pozwól mu dokonać wyboru. Krok 6: Przejmij inicjatywę. Zareaguj na niepożądane zachowanie, przerywając je, ale pozwól dziecku samodzielnie znaleźć odpowiedź, dlaczego tak się zadziało, dzięki temu dostrzeże konsekwencje swojego postępowania. Krok 7: Wspólnie rozwiążcie problem. Nie narzucaj rozwiązania problemu, ale porozmawiaj z dzieckiem, co można zrobić w takiej sytuacji. Razem podejmijcie decyzję.

\footnotetext{
33 Tamże.

34 Tamże.

35 A. Kołakowski, A. Pisula, dz. cyt.
} 
- Warto stosować często pochwały i zachęty, one pomagają w podnoszeniu samooceny dziecka, dodają wiary we własne siły, pomagają lepiej radzić sobie z problemami, dają poczucie bezpieczeństwa. Chwaląc, warto stosować pochwałę opisową, czyli opisać, co widzimy, co czujemy w związku z pozytywnym zachowaniem dziecka.

- Należy wspierać dziecko w wyrażaniu emocji - nazwać emocje, które dziecko przeżywa, akceptować wszystkie emocje; rozdzielać akceptację dla emocji od akceptacji dla sposobów ich wyrażania. Warto reagować na emocje dziecka w otwarty i szczery sposób, to pomaga budować pozytywne więzi.

- Kluczowe jest modelowanie właściwych reakcji dziecka na sytuacje trudne, także porażkę. Dobrym pomysłem jest, gdy ważny dorosły pokazuje dziecku swoją postawą, jak sobie radzi, gdy np. przegra rundkę w grę planszową.

- Nauczyciele, rodzice powinni wprowadzić w procesie wychowawczym ustalony program dnia, co zapewni przewidywalność oraz regularność w pracy - w zakresie zajęć dydaktycznych, zabawy, odpoczynku, posiłków itp. Pozwala to unikać zaskoczenia i wywoływania silnych emocji.

- Wskazane jest czytanie dzieciom odpowiednich książek, opowiadań, które będą kształtować pożądane zachowania prospołeczne.

- Nie wolno stosować kar cielesnych, ale także poniżać dziecka, wyśmiewać. Takie zachowania są świadectwem nieudolności i klęski pedagogicznej ${ }^{36}$.

- Rodzice, nauczyciele powinni uważnie słuchać dzieci, tego, co mają do powiedzenia. Należy pamiętać, że już od najmłodszych lat dzieci komunikują się nie tylko w sposób werbalny ${ }^{37}$.

Nauczyciele, rodzice powinni także korzystać z profesjonalnych szkoleń, organizowanych przez specjalistyczne placówki, aby podnosić swoje kompetencje wychowawcze.

\section{Podsumowanie}

Ważnym zadaniem edukacji przedszkolnej, oprócz kształtowania kompetencji poznawczych, jest także rozwijanie uczuć, wrażliwości i orientacji moralnej dziecka. Tym bardziej, że w pierwszych latach życia rozwój w poszczególnych sferach: ruchowej, umysłowej i emocjonalno-społecznej jest ściśle ze sobą powiązany. Niezaspokojenie potrzeb w jednej sferze oddziałuje negatywnie na pozostałe ${ }^{38}$. Dzieci, których rozwój psychoruchowy przebiega nieprawidłowo, nieharmonijnie, z opóźnieniem, często sprawiają problemy natury wychowawczej. Zjawisko trudności wychowaw-

\footnotetext{
36 D. Siemek, dz. cyt.

37 F. J. O'regan, dz. cyt.

${ }^{38}$ D. Siemek, dz. cyt.
} 
czych wiąże się także $\mathrm{z}$ wadliwym oddziaływaniem pedagogicznym ze strony rodziców, nauczycieli oraz innych dorosłych z najbliższego otoczenia dziecka.

Należy mieć świadomość, że przyczyny niewłaściwego zachowania mogą być bardzo złożone, częściowo zależne od dziedziczonych genów, ale także od sposobu wychowania, na który zdecydowanie można mieć większy wpływ. Za każdym razem, kiedy dziecko źle się zachowuje, warto zanotować, co poprzedziło takie zachowanie, co się wydarzyło, jak ono się przejawia i co nastąpiło bezpośrednio po nim. To pozwoli ocenić nauczycielom, rodzicom, kiedy pojawia się niepożądane zachowanie i czy zawsze ma to miejsce w podobnych okolicznościach, a także jak na nie konstruktywnie reagować - poprzesz niedopuszczenie do powstania trudnego zachowania, poprzez spowodowanie, że dziecko poniesie negatywne konsekwencje trudnego zachowania czy poprzez wzmocnienie zachowania pożądanego ${ }^{39}$.

W postępowaniu dorosłych wobec dzieci, oprócz czynników zwiększających ryzyko wystąpienia trudności w zachowaniu, mogą pojawiać się zachowania zmniejszające ryzyko, tak zwane czynniki protekcyjne, do których między innymi należą: dobra relacja dziecka przynajmniej z jednym opiekunem, stabilna sytuacja rodzinna, przewidywalny styl życia rodziny, wspierający rodzice, którzy są autorytetem dla dziecka, nauka w dobrych, profesjonalnych placówkach edukacyjnych, bezpieczne otoczenie, zorganizowany czas poza pobytem w placówce, akceptacja przez rówieśników, którzy mają dobry wpływ na zachowanie dziecka, wczesne osiągnięcie przez dziecko umiejętności w samoregulacji zachowania i emocji, dobrze ukształtowane kompetencje społeczne oraz łatwość uczenia się ${ }^{40}$. Bardzo istotne jest także mądre, zrównoważone postępowanie wychowawcze dorosłych z najbliższego otoczenia dziecka - rodzinnego i edukacyjnego, które przeciwdziała wystąpieniu i utrwaleniu się trudnych, niepożądanych zachowań.

Ponadto, ważne jest wczesne rozpoznanie indywidualnych potrzeb i możliwości dziecka w zakresie wszystkich sfer rozwojowych oraz uwzględnienie potrzeb i możliwości rodziny. Jak najwcześniejsze udzielenie pomocy psychologiczno-pedagogicznej dziecku przejawiającemu trudności w rozwoju psychoruchowym determinuje jego szanse edukacyjne i późniejszą karierę życiową. Brak podjęcia wczesnej stymulacji rozwoju będzie powodował pogłębianie się zaburzeń, zahamowanie rozwoju dziecka lub też pojawienie się wtórnych problemów rozwojowych. Zbyt późne podjęcie działań naprawczych prowadzi do powstania i utrwalenia nieprawidłowych wzorców zachowań, które trudno później wyeliminować i które wpływają negatywnie na funkcjonowanie ${ }^{41}$.

${ }^{39}$ Procedura ta odpowiada modelowi behawioralnemu ABC (ang. Antecendents Behaviour Consequences), który stosowany jest w behawioralnej analizie zachowania. Zob. A. Kołakowski, A. Pisula, dz. cyt.

40 Tamże.

${ }^{41}$ R. Piotrowicz, $W$ poszukiwaniu interdyscyplinarnego modelu wsparcia małego dziecka i rodzi$n y$, [w:] R. Piotrowicz (red.), Interdyscyplinarne uwarunkowania rozwoju małego dziecka, Wydawnictwo Akademii Pedagogiki Specjalnej, Warszawa 2014. 
Każde dziecko zamieszkałe w dowolnym miejscu w Polsce powinno otrzymać w swoim środowisku lokalnym adekwatną pomoc w rozwoju, a rodzice uzyskać wsparcie psychologiczne i socjalne w zapewnieniu dziecku odpowiednich warunków do terapii ${ }^{42}$.

Nieudzielenie pomocy dziecku we wczesnym okresie, którego rozwój przebiega w sposób nieprawidłowy, prowadzi do utrwalenia się nieprawidłowych wzorców zachowań, które później trudno skorygować, a jeszcze trudniej wyeliminować. Objęcie pomocą psychologiczno-pedagogiczną może zniwelować, a nawet wykluczyć dysharmonie rozwojowe czy deficyty. Powszechnie wiadomo, że zaburzenia nieskorygowane narastają z wiekiem oraz utrudniają późniejszą edukację i terapię ${ }^{43}$.

\section{Bibliografia}

Cieszyńska J., Korendo M., Wczesna interwencja terapeutyczna. Stymulacja rozwoju dziecka. Od noworodka do 6 roku życia, Wydawnictwo Edukacyjne, Kraków 2008.

Faber A., Mazlish E., Jak mówić, żeby dzieci nas słuchały, jak słuchać, żeby dzieci do nas mówiły, Media Rodzina, Poznań 2001.

Głodkowska J., Model kształcenia uczniów ze specjalnymi potrzebami edukacyjnymi różnice nie moga dzielić, [w:] Podniesienie efektywności kształcenia uczniów ze specjalnymi potrzebami edukacyjnymi. Materiały dla nauczycieli, część I, Ministerstwo Edukacji Narodowej, Warszawa 2010.

Gordon T., Wychowanie bez porażek, Instytut Wydawniczy PAX, Warszawa 2003.

Jaczewski A., Biologiczne i medyczne podstawy rozwoju i wychowania, Wydawnictwo Akademickie „Żak”, Warszawa 2005.

Kendall P.C., Zaburzenia okresu dzieciństwa i adolescencji, Gdańskie Wydawnictwo Psychologiczne, Gdańsk 2004.

Kołakowski A., Pisula A., Sposób na trudne dziecko, Gdańskie Wydawnictwo Psychologiczne, Sopot 2012.

Kwaśny A., Trąbińska-Haduch M., Być mamą, materiały szkoleniowe, Fundacja Dzieci Niczyje, Warszawa 2001.

Nartowska H., Opóźnienia i dysharmonie rozwoju dziecka, Wydawnictwa Szkolne i Pedagogiczne, Warszawa 1980.

Nartowska H., Zestawienie charakterystycznych objawów zaburzeń i zabiegów wyrównawczych, [w:] M. Dunin-Wąsowicz (red.), Vademecum nauczyciela sześciolatków, Wydawnictwa Szkolne i Pedagogiczne, Warszawa 1980.

${ }_{42}$ T. Serafin, Wybrane aspekty dotyczace możliwości prowadzenia działań wspierających rozwój małych dzieci zagrożonych niepetnosprawnościa lub niepetnosprawnych oraz ich rodzin, Oficyna Wydawnicza Impuls, Kraków 2012, s. 13.

${ }^{43}$ A. Twardowski, dz. cyt., s. 147. 
O’regan F.J., Jak pracować z dziećmi o specjalnych potrzebach edukacyjnych, Wydawnictwo Liber, Warszawa 2005.

Pileccy W. i J. (red.), Stymulacja psychoruchowego rozwoju dzieci o obniżonej sprawności umysłowej, Wydawnictwo Naukowe Akademii Pedagogicznej, Kraków 2003.

Piotrowicz R., W poszukiwaniu interdyscyplinarnego modelu wsparcia małego dziecka i rodziny, [w:] R. Piotrowicz (red.), Interdyscyplinarne uwarunkowania rozwoju małego dziecka, Wydawnictwo Akademii Pedagogiki Specjalnej, Warszawa 2014.

Popielarska A., Popielarska M., Psychiatria wieku rozwojowego, PZWL, Warszawa 2000.

Przewęda R., Rozwój motoryczny, [w:] A. Jaczewski (red.), Biologiczne i medyczne podstawy rozwoju i wychowania, Wydawnictwo Akademickie „Żak”, Warszawa 2005.

Rudkowska G., Uczniowie z trudnościami w rozwoju emocjonalno-społecznym, [w:] W. Pilecka, G. Rudkowska, L. Wrona (red.), Podstawy psychologii. Podręcznik dla studentów kierunków nauczycielskich, Wydawnictwo Naukowe Akademii Pedagogicznej, Kraków 2005.

Sakowska J., Szkoła dla rodziców i wychowawców, Wydawnictwo CMPP-P MEN, Warszawa 1999.

Serafin T., Wybrane aspekty dotyczace możliwości prowadzenia działań wspierających rozwój małych dzieci zagrożonych niepetnosprawnością lub niepetnosprawnych oraz ich rodzin, Oficyna Wydawnicza Impuls, Kraków 2012.

Siemek D., Problemy wychowawcze wieku przedszkolnego, Instytut Wydawniczy Związków Zawodowych, Warszawa 1987.

Spionek H., Problemy rozwojowe i wychowawcze wczesnego dzieciństwa, Wydawnictwo Książka i Wiedza, Warszawa 1972.

Twardowski A., Wczesne wspomaganie rozwoju dzieci z niepetnosprawnościami w środowisku rodzinnym, Wydawnictwo Naukowe Uniwersytetu Adama Mickiewicza, Poznań 2012.

Thompson J., Specjalne potrzeby edukacyjne, Państwowe Wydawnictwo Naukowe, Warszawa 1987.

Wolańczyk T., Kołakowski A., Skotnicka M., Nadpobudliwość psychoruchowa u dzieci, Wydawnictwo BiFolium, Lublin 1999.

Woynarowska B., Kowalewska A., Izdebski Z., Komosińska K., Biomedyczne podstawy kształcenia i wychowania, Wydawnictwo PWN, Warszawa 2010. 
Difficult behaviours in preschool-aged children - abnormalities in psychomotor development or mistakes in the upbringing process?

Abstract: This article discusses some aspects of the difficult behaviours that are manifested by preschool-aged children. These behaviours may be a result of some abnormalities in development and mistakes made by adults in the educational process. The difficulties in behaviour, though often onerous for the functioning of the child him/herself and his/her parents and teachers, are not disabilities. Although these difficult behaviours are partially biologically conditioned, to a large extent they depend on the methods of the upbringing process. The paper contains guidelines for parents and teachers on how to deal with children in order to minimise difficult behaviour and reduce the risk of its occurrence. Providing early support to a child promotes better functioning in the future because it ensures more harmonious development, facilitates learning, and increases the chances of a satisfying life in society in adulthood.

Keywords: difficult behaviours in preschool-aged children, disturbances in the dynamics of nervous processes, mistakes in the upbringing process, early intervention

\footnotetext{
About the author: Karolina Skarbek - PhD of social sciences in the discipline of pedagogy, psychologist, graduated from the Warsaw University. She works as an adjunct at the Faculty of Educational Sciences at The Maria Grzegorzewska University. She conducts scientific research in the field of mathematical giftedness in children, the learning process, and the diagnosis of children. In addition, she works as a psychologist in one of the psychological and pedagogical counseling centers in Warsaw, where she deals with the diagnosis and therapy of children, supporting parents and teachers.
} 


\title{
Karolina Ruta-Korytowska* (iD) https://orcid.org/0000-0003-1534-532X
}

Uniwersytet Adama Mickiewicza w Poznaniu

Marta Wrześniewska-Pietrzak** (iD https://orcid.org/0000-0002-9667-2519

Uniwersytet Adama Mickiewicza w Poznaniu

\section{Obraz szkoły i edukacji uczniów głuchych w Polsce w wypowiedziach dorosłych osób niesłyszących}

\begin{abstract}
Streszczenie: Celem artykułu jest wskazanie sposobów wartościowania doświadczeń edukacyjnych głuchych, którzy kształcili się w różnego rodzaju placówkach (szkołach ogólnodostępnych, ośrodkach specjalnych). Część analityczną tekstu poprzedza krótki rys historyczny sposobów edukacji osób niesłyszących w Polsce na przestrzeni wieków. $\mathrm{Z}$ wypowiedzi głuchych, które stanowią podstawę materiałową analiz, wyłania się obraz szkoły i sposobów kształcenia obecny w latach 80. i 90. ubiegłego wieku. Piszący wskazują na problemy i konsekwencje wynikające $\mathrm{z}$ kształcenia oralistycznego. Ich spostrzeżenia
\end{abstract}

* Karolina Ruta-Korytowska - doktor nauk humanistycznych w zakresie językoznawstwa współczesnego, adiunkt w Instytucie Filologii Polskiej UAM, lektor języka polskiego jako obcego. Obecnie przedmiotem jej badań jest polski język migowy i metodyka nauczania osób z dysfunkcją słuchu języka polskiego jako obcego. Laureatka V Konkursu im. Majera Bałabana na najlepsze prace doktorskie i magisterskie o tematyce żydowskiej, organizowanego przez Żydowski Instytut Historyczny im. E. Ringelbluma oraz Nagrody im. Artura Rojszczaka przyznana przez Klub Stypendystów Fundacji na rzecz Nauki Polskiej.

** Marta Wrześniewska-Pietrzak - doktor habilitowany nauk humanistycznych w zakresie językoznawstwa, adiunkt w Instytucie Filologii Polskiej UAM. Naukowo zajmuje się problematyką tożsamości osób głuchych w Polsce, a także surdoglottodydaktyką oraz nauczaniem polskiego języka migowego. W kręgu jej zainteresowań badawczych znajduje się też semantyka leksykalna i aksjologia językoznawcza, autorka książek: Aksjologiczne wyznaczniki tożsamości w wypowiedziach głuchych i czasopiśmie środowiskowym „Świat Ciszy” (2017) oraz „Miało być odlotowo, czadowo, bojowo...". Język i świat wartości czasopism szkolnych na tle pism młodzieżowych (2012). 
są podobne do argumentów podnoszonych dziś przez środowisko akademickie i specjalistów zajmujących się kształceniem osób głuchych w Polsce.

Słowa kluczowe: edukacja głuchych, kształcenie niesłyszących w Polsce, obraz szkoły $\mathrm{w}$ wypowiedziach głuchych

\section{Edukacja głuchych w Polsce - historia i współczesność}

Kształcenie instytucjonalne osób z uszkodzonym słuchem na świecie zaczęło się wraz z otwarciem pierwszej szkoły dla głuchych w 1770 roku w Paryżu. Inicjatorem i założycielem był ks. Charles Michel de l’Epée, który wprowadził nauczanie przy użyciu znaków językowo-migowych. Przyjmuje się, że w Polsce pierwszą placówką oświatową dla głuchych był powstały w 1817 roku Instytut Głuchoniemych w Warszawie ${ }^{1}$.

W szkołach dla głuchych na całym świecie ścierały się ze sobą dwa stanowiska względem sposobu prowadzenia edukacji, które w skrócie można zawrzeć w pytaniu: mówić czy migać? Metody oralne zakładały, że niesłyszący nauczy się odczytywania mowy z ust i wykształci zdolność nadawania komunikatów fonicznych. Metoda ta miała szerokie zastosowanie na całym świecie. Językowi migowemu odmawiano statusu systemu językowego. Od końca XIX wieku traktowany był on jako bariera, która utrudnia rozwój niesłyszących. Uważano, że jest to tylko zbiór przypadkowych znaków migowych i gestów, w którym nie obowiązują żadne zasady gramatyczne i który jest ograniczony do wyrażania tylko zjawisk rzeczywistych, nie umożliwia wypowiedzi abstrakcyjnych². Twierdzenia te wynikały przede wszystkim z nieznajomości języka migowego i braku badań lingwistycznych w tym zakresie. Ponadto dodać trzeba, że w tym czasie sam język migowy w Polsce był systemem słabo rozwiniętym³ ${ }^{3}$.

Upowszechnienie edukacji w środowisku niesłyszących miało miejsce dopiero w XX wieku. Pierwsza matura głuchych w Polsce odbyła się dopiero w 1979 roku w Technikum Budowlanym w Wejherowie. Do tej pory nie było przewidzianej edukacji na poziomie szkolnictwa wyższego dla osób niesłyszących.

${ }^{1}$ Niektóre źródła podają, że pierwszą szkołą była założona w 1816 roku przez ks. Jakuba Falkowskiego tzw. szkoła wydziałowa w Szczuczynie, którą później przeniesiono do Warszawy i od tego czasu uznaje się działalność Warszawskiego Instytutu Głuchoniemych, który do dzisiaj działa przy Placu Trzech Krzyży. Za: D. Podgórska-Jachnik, Historia wychowania i edukacji głuchych z perspektywy surdopedagogiki początku XXI wieku, [w:] J. Błeszyński, D. Baczała, J. Binnebesel (red.), Historyczne dyskursy nad pedagogika specjalna, Wydawnictwo Naukowe Wyższej Szkoły Edukacji Zdrowotnej, Łódź 2008, s. 163-194.

${ }^{2}$ Więcej na temat mitów przypisywanych polskiemu językowi migowemu w tekście Piotra Tomaszewskiego, Polski język migowy (PJM) - mity i fakty, „Poradnik Językowy”, nr 6/2004, s. 59-72.

${ }^{3}$ B. Szczepankowski B., Niesłyszący - głusi-głuchoniemi. Wyrównywanie szans, Wydawnictwa Szkolne i Pedagogiczne, Warszawa 1999, s. 114. 
Polski system kształcenia i wychowania dzieci niesłyszących, wynikający z rozporządzenia Ministerstwa Edukacji Narodowej ${ }^{4}$, które weszło w życie we wrześniu 2017 roku, można przedstawić jako składający się z:

- kształcenia specjalnego odbywającego się w specjalnych placówkach kształcenia i wychowania dla dzieci głuchych na poszczególnych etapach kształcenia (przedszkola, szkoły);

- kształcenia integracyjnego (przedszkola, szkoły, klasy i oddziały integracyjne);

- edukacji włączającej.

Działania te wspierane są wczesnym wspomaganiem rozwoju, co ma miejsce w ośrodkach wczesnej interwencji i zespołach wczesnego wspomagania.

Dziecko przed podjęciem edukacji szkolnej przechodzi badania psychologiczne, które pozwalają określić jego poziom funkcjonowania poznawczego i społecznego. Na podstawie tych badań poradnia psychologiczno-pedagogiczna wydaje orzeczenie o potrzebie kształcenia specjalnego, jednak to rodzice podejmują decyzję, czy dziecko taką ścieżkę edukacji rozpocznie. Rodzice dziecka mogą wybrać szkołę specjalną, integracyjną lub ogólnodostępną, która realizuje edukację włączającą. Dla rodziców słyszących dziecka z deficytem słuchu wybór szkoły jest zadaniem jeszcze trudniejszym niż dla niesłyszących. Często rodzice ci przeżywają traumę powodowaną głuchotą własnego dziecka. Porównywana jest ona ze stanem żałoby ${ }^{5}$, co nie jest bezpodstawne, rodzice bowiem w początkowym stadium zaprzeczają głuchocie dziecka, starają się żyć tak, jakby głuchoty nie było.

Dzisiaj opiekunowie niesłyszących dzieci wybierają najczęściej oddziały integracyjne w szkołach ogólnodostępnych ${ }^{6}$. Wybór ten podyktowany jest najczęściej tym, że rozwój technologii wspomagających słyszenie (aparaty słuchowe, implanty ślimakowe) znacznie zwiększa szanse na opanowanie mowy dźwiękowej. Ponadto nie ma konieczności pozostawiania dziecka w internacie, gdyż szkoły z oddziałami integracyjnymi są powszechnie dostępne. Wybór szkoły z oddziałem integracyjnym daje rodzicom poczucie, że dziecko uczęszcza do „normalnej” placówki edukacyjnej, gdzie ma ono kontakt ze słyszącymi rówieśnikami. Nie zawsze przynosi to zamierzone skutki, gdyż możliwości percepcyjne dziecka głuchego mogą powodować trudności w nabywaniu wiedzy ${ }^{7}$. Trzeba też mieć na uwadze fakt, że do klas integracyjnych trafiają także dzieci z obniżoną sprawnością intelektualną. Nierzadko dzieci niesłyszące traktowane są na równi z takimi uczniami, co powoduje, że nie wiedzą one, czy po-

${ }^{4}$ Rozporządzenie Ministra Edukacji Narodowej z dnia 28 sierpnia 2017 roku (Dz.U. 31.08.2017, poz. 1652).

5 A. Wzorek, Rodzina z dzieckiem z zaburzeniami stuchu - spojrzenie systemowe, „Psychoterapia", $\mathrm{nr} 4(151) / 2009$, s. 54.

${ }^{6}$ M. Sak, Kształcenie głuchych $w$ szkołach masowych $i$ w klasach mieszanych $z$ innymi niepetnosprawnościami, [w:] M. Sak (red.), Edukacja głuchych, Biuro Rzecznika Praw Obywatelskich, Warszawa 2014, s. 72-73.

${ }^{7}$ M. Januszewicz, M. Jura, J. Kowal, Każdy ma prawo do nauki. Prawo głuchych do dostępu do jezzkka i edukacji, [w:] M. Sak (red.), dz. cyt., s. 8-16. 
winny identyfikować się z uczniami słyszącymi w normie intelektualnej, czy z niepełnosprawnymi intelektualnie ${ }^{8}$.

Poza klasami integracyjnymi dziecko z wadą słuchu może uczęszczać do ośrodka szkolno-wychowawczego, w którym stosowane są różne formy komunikacji mające na celu przyswojenie wiedzy i ułatwienie odbioru. Specyfika takich placówek polega na tym, że uczeń ma stały kontakt $\mathrm{z}$ dwoma językami - fonicznym na lekcjach, jeśli nauczyciel nie zna polskiego języka migowego (lub preferowana jest przez uczniów w danej placówce metoda oralna), i migowym (w kontakcie z uczniami na przerwach i w internacie). W takich warunkach dziecko ma możliwość rozwoju dwujęzycznego, co w ostatnim czasie jest bardzo mocno promowane w środowisku osób zajmujących się wychowaniem i edukacją niesłyszących ${ }^{9}$. Koncepcja dwujęzyczności w kształceniu osób z wadą słuchu zapoczątkowana została przez Danielle Bouvet, która w swojej książce ${ }^{10}$ opisała eksperyment polegający na utworzeniu dwujęzycznej klasy dla dzieci sześcioletnich. Eksperyment ten polegał na wprowadzeniu do procesu nauczania dwóch języków: francuskiego fonicznego i migowego, przy czym ten drugi pełnił tylko rolę wsparcia w edukacji. Był to istotny krok poczyniony w sprawie dostosowania sposobu nauczania do potrzeb niesłyszących.

W Polsce nauczanie dwujęzyczne jest propagowane od niedawna, choć trzeba mocno podkreślić - nauczanie dwujęzyczne nie jest wdrażane systemowo ${ }^{11}$. By mogło ono funkcjonować w szkołach, muszą zostać spełnione ku temu odpowiednie warunki, jak chociażby znajomość języka migowego wśród nauczycieli. Edukacja dwujęzyczna została głuchym zagwarantowana prawnie w dokumencie Deklaracja z Salamanki w sprawie zasad, polityki i praktyki w zakresie specjalnych potrzeb edukacyjnych ${ }^{12}$, który został przyjęty w 1994 roku przez rządy 92 państw (w tym Polski). Założenia zawarte w Deklaracji zostały uwzględnione przez Ministerstwo Edukacji Narodowej, które w 1997 roku opracowało „Kierunki przemian w kształceniu uczniów niepełno-

${ }^{8}$ M. Czajkowska-Kisil, A. Siepkowska, M. Sak, Edukacja głuchych w Polsce, [w:] M. Świdziński (red.), Sytuacja osób głuchych w Polsce. Raport zespołu ds. Głuchych przy Rzeczniku Praw Obywatelskich, Biuro Rzecznika Praw Obywatelskich, Warszawa 2014, s. 13-27.

9 Zob. M. Świdziński, S. Fabisiak, Dwujęzyczność - zagrożenie, wyzwanie, jedyna szansa, „Audiofonologia" 2010, t. 26, s. 15-19.

${ }^{10}$ D. Bouvet, Mowa dziecka. Wychowanie dwujęzykowe dziecka niestyszacego, Wydawnictwa Szkolne i Pedagogiczne, Warszawa 1996.

${ }^{11}$ Należy jednak podkreślić, że w ramach projektu W stronę edukacji dwujęzycznej dzieci głuchych, który został objęty patronatem Pełnomocnika Rządu ds. Równego Traktowania i Łódzkiego Kuratora Oświaty, wypracowane zostały rekomendacje rozwiązań systemowych dla Ministerstwa Edukacji Narodowej, Ministerstwa Pracy i Polityki Społecznej, Ministerstwa Nauki i Szkolnictwa Wyższego i Ministerstwa Zdrowia. Koordynatorem merytorycznym projektu była Magdalena Dunaj z PZG Oddział w Łodzi. Rekomendacje te nie zostały jednak wdrożone. Więcej na temat projektu na stronie: http://www.pzg.lodz.pl/edukacja/\#page-top (dostęp: 15.03.2018).

12 Deklaracja $\mathrm{z}$ Salamanki w sprawie zasad, polityki i praktyki w zakresie specjalnych potrzeb edukacyjnych, https://rownosc.info/media/uploads/deklaracja z salamanki.pdf (dostęp: 15.03.2018). 
sprawnych”. W dokumencie tym zwraca się uwagę, że kształcenie dwujęzyczne jest najbardziej korzystne dla rozwoju głuchego dziecka.

Bez względu na wybraną ścieżkę edukacji, uczeń z wadą słuchu ma obowiązek przystąpienia do egzaminów. W przypadku egzaminu maturalnego, w zależności od wady słuchu, uczniowie mogą korzystać z różnych form udogodnieńn ${ }^{13}$. Zgodnie z dokumentami prawnymi od 2015 roku uczniowie słabosłyszący podczas ustnej części matury mogą korzystać z urządzeń technicznych ułatwiających kontakt, jak również z wydłużonego czasu trwania egzaminu (nie więcej niż 15 minut) z języka polskiego i obcego nowożytnego. Część pisemna może zostać wydłużona o nie więcej niż $30 \mathrm{mi}$ nut w przypadku wszystkich przedmiotów za wyjątkiem języka obcego nowożytnego. Egzamin z języka obcego nowożytnego odbywa się w osobnej sali i uczeń może skorzystać z:

- arkusza standardowego z języka obcego nowożytnego z możliwością korzystania z urządzeń technicznych odpowiednich do wady słuchu (słuchawki i płyta CD);

- arkusza egzaminacyjnego z języka obcego nowożytnego dostosowanego do dysfunkcji na podstawie arkuszy standardowych za wyjątkiem zadań testujących rozumienie ze słuchu.

Jeśli zachodzi taka potrzeba, szkoła powinna zapewnić obecność surdopedagoga lub tłumacza języka migowego, by w ten sposób uzyskać kontakt ze zdającym.

Dla uczniów z wadą słuchu poniżej 70 dB arkusze egzaminacyjne ze wszystkich przedmiotów są dostosowywane pod kątem sposobu formułowania treści zadań. Modyfikacje te nie obejmują terminów typowych dla sprawdzanej dziedziny wiedzy.

W przypadku uczniów niesłyszących dostosowanie formy egzaminu również polega na wydłużeniu o 15 minut czasu jego trwania. Zdający ma także możliwość zdawania ustnej części z języka polskiego w języku migowym lub - jeśli uczeń nie mówi i nie miga - w postaci prezentacji przygotowanej na piśmie. Niesłyszący nie musi też zdawać egzaminu ustnego z języka obcego.

Anna Wiśniewska ${ }^{14}$ przeprowadziła badania nad trafnością zmian wprowadzanych przez Centralną Komisję Egzaminacyjną w arkuszach egzaminacyjnych, służących dopasowaniu ich do potrzeb uczniów słabosłyszących i niesłyszących. Grupą badawczą byli uczniowie ośrodków szkolno-wychowawczych. Wiśniewska przebadała

${ }^{13} \mathrm{Na}$ podstawie dokumentów prawnych dyrektor Centralnej Komisji Egzaminacyjnej wskazuje szczegółowe sposoby dostosowania warunków i form przeprowadzania egzaminu maturalnego do potrzeb uczniów ze specjalnymi potrzebami edukacyjnymi, w tym do potrzeb uczniów niesłyszących, https://cke.gov.pl/images/files/komunikaty Dyrektora/sierpien 2014/20140829 Komunikat Egzamin maturalny pf.pdf, s. 5-6. Wskazane w dalszej części artykułu udogodnienia podawane są na podstawie tego dokumentu.

${ }^{14}$ A. Wiśniewska swoje analizy przeprowadziła w okresie od 15 maja do 14 czerwca 2014 roku. Badaniem objęła 340 uczniów z 9 publicznych szkół gimnazjalnych, które mieszczą się na terenie 5 województw, co w przekonaniu badaczki pozwala na uogólnienie wyników na całą populację (prawdopodobieństwo bowiem wynosi 93\%); Wiśniewska A., Egzaminy zewnętrzne a uczniowie z wada stuchu - studium przypadku, Polski Związek Głuchych Oddział Łódzki, Łódź 2016, s. 93-96. 
sposób dopasowania gimnazjalnych arkuszy egzaminacyjnych z przedmiotów przyrodniczych i zauważyła, że dotyczą one treści zadania i/lub sposobu jego prezentacji. W przypadku modyfikacji merytorycznej treści zadań zmiany dotyczą poziomu zawartości lub jej okrojenia. Zmiany sposobu prezentowania zadań podzielić można na:

- zadania zmodyfikowane pod względem sposobu formułowania poleceń;

- zadania z dodaną ilustracją;

- zadania z dodanymi wyjaśnieniami pomocniczymi ${ }^{15}$.

Wnioski z przeprowadzonych badań pokazują, że wprowadzane zmiany zawartości merytorycznej zadań prowadzą często do zmiany poziomu ich trudności, a próby dostosowywania sposobu prezentacji treści egzaminacyjnych dla uczniów z wadą słuchu nie przynoszą oczekiwanych skutków, ponieważ nie mają wpływu na zwiększenie poprawnych odpowiedzi. Badania Wiśniewskiej pokazały również, że wprowadzane modyfikacje powodowały, iż uczniowie udzielali odpowiedzi w sposób losowy częściej niż przed zmianami. Ponadto uczniowie rzadko kiedy korzystają z możliwości wydłużenia czasu trwania egzaminu.

W ostatnich latach obserwuje się wzrost liczby osób niesłyszących, którzy podejmują studia wyższe ${ }^{16}$. Nadal jednak często osoby te napotykają trudności, które związane są z kilkoma czynnikami. Jednym z nich jest niewystarczający poziom kompetencji w języku polskim, jak również niski poziom wiedzy po skończeniu kształcenia w szkołach dla głuchych. Nierzadko barierą w funkcjonowaniu osób niesłyszących na uczelni jest niska świadomość słyszących ${ }^{17}$ na temat sposobów funkcjonowania niesłyszących i ich potrzeb. Nowelizacja ustawy Prawo o szkolnictwie wyższym ${ }^{18} \mathrm{z}$ dnia 18 marca 2011 roku gwarantuje osobom niepełnosprawnym pełen udział w kształceniu. Na potrzeby studentów niesłyszących pomoc w procesie dydaktycznym polega głównie na zapewnieniu im tłumacza w polskim języku migowym. W rzeczywistości jest to spory problem dla uczelni, ponieważ w Polsce nie funkcjonuje jeszcze ujednolicony system certyfikacji tłumaczy języka migowego. W roli tłumacza nierzadko występują członkowie rodziny głuchego studenta, które nie są przygotowane do tłumaczenia na poziomie uniwersyteckim ze względu na specyficzną terminologię naukową ${ }^{19}$.

Przykładem dobrych praktyk zmierzających do likwidowania barier i udostępniania dydaktyki akademickiej osobom z dysfunkcją słuchu jest oferta przygotowana

15 Tamże, s. 69.

16 Zob. m.in. A. Butkiewicz, M. Czajkowska-Kisil, Głusi i nie(do)słyszący na uczelni wyższej, [w:] M. Świdziński (red.), dz. cyt., s. 28-29.

17 Wnioski takie wynikają z wielu spotkań ze studentami, a także licealistami, które od kilku lat prowadzone są przez autorki tekstu.

18 Mowa o ustawie, której pełen tytuł brzmi Prawo o szkolnictwie wyższym, ustawy o stopniach naukowych i tytule naukowym oraz o stopniach i tytule w zakresie sztuki oraz niektórych innych ustaw z dnia 18 marca 2011 roku.

19 P. Rutkowski, M. Talipska, Kształcenie akademickie głuchych, [w:] M. Sak (red.), dz. cyt., S. $82-88$. 
przez Biuro Uniwersytetu im. Adama Mickiewicza w Poznaniu ds. Studentów z Niepełnosprawnościami. W ramach swojej działalności jednostka ta gwarantuje osobom głuchym i niedosłyszącym następujące formy wsparcia:

- stypendium specjalne dla studentów niepełnosprawnych;

- indywidualna organizacja studiów dopasowana do potrzeb i możliwości studenta/ki;

- wsparcie asystenta dydaktycznego/tłumacza języka migowego;

- wypożyczanie sprzętu wspomagającego słyszenie - systemów FM;

- miejsce w domach studenckich przystosowanych do potrzeb studentów z niepełnosprawnością ( $\mathrm{w}$ tym pokoje z komunikatami świetlnymi dla studentów nie(do)słyszących);

- działalność Zrzeszenia Studentów Niepełnosprawnych UAM „Ad Astra”;

- lektoraty języka angielskiego dla studentów nie(do)słyszących w multimedialnej pracowni nauki języków Obcych;

- zajęcia z praktycznej nauki języka polskiego dla studentów nie(do)słyszących.

Jak zauważa Paweł Rutkowski i Małgorzata Talipska, rozwiązaniem, którego oczekują głusi, jest umożliwienie im zdawania egzaminu z języka polskiego jako obcego ${ }^{20}$.

Z uwagi na to, że obecnie często wskazywane są żądania niesłyszących dotyczące rozwiązań edukacyjnych, ważne staje się zwrócenie uwagi na ich wypowiedzi zarówno współczesne, jak i te dawniejsze. Celem niniejszego tekstu jest zatem ukazanie sposobów postrzegania i zarazem wartościowania własnych doświadczeń edukacyjnych przez osoby głuche, kształcone w szkołach ogólnodostępnych lub placówkach specjalnych kształcących osoby niesłyszące. Podstawę materiałową niniejszego badania stanowią wypowiedzi 37 osób głuchych zebrane przez Marię Polok i opublikowanych w 2008 roku w zbiorze Głusi mówią ${ }^{21}$. Teksty te to swoiste biografie osób niesłyszących, w których przedstawiają oni swoje życie, często opisują sposoby radzenia sobie z głuchotą, opisują życie codzienne. Co istotne, w każdej z publikowanych wypowiedzi znajduje się odniesienie do doświadczeń szkolnych, czasem nawet przedszkolnych. Piszący zwracają uwagę na własne samopoczucie w szkole, relacje z innymi uczniami, nauczycielami, a także sam proces nauczania. $Z$ uwagi na to, że autorzy to osoby w różnym wieku - zarówno ludzie młodzi, studiujący, jak i osoby starsze, opisane doświadczenia nie odnoszą się do określonego czasu, w którym odbywali oni edukację. Należy jednak podkreślić, że obraz szkoły i kształcenia, który przedstawiają, odnosi się do rzeczywistości lat 80. i 90. ubiegłego wieku, a w kilku przypadkach gdy autorem jest osoba starsza - obrazuje edukację z lat powojennych ${ }^{22}$. Opisanie tego

20 Tamże, s. 88 .

${ }^{21}$ M. Polok (red.), Głusi mówią, Baterex Jan i Kazimierz Kwaśniewicz, Racibórz 2008. W dalszej części publikacji przytaczane przykłady opisywane są za pomocą skrótu GM, po którym wskazany jest numer strony, z której dana wypowiedź pochodzi.

22 Zebrany tu materiał można porównać z analizą obrazu szkoły i edukacji niesłyszących w Polsce odczytaną z wypowiedzi ankietowych osób głuchych, którzy edukację kończyli w ciągu 
historycznego już materiału pozwoli pokazać, że problemy dyskutowane dziś przez specjalistów zajmujących się kształceniem niesłyszących obecne są też w zebranych wypowiedziach. W tytule publikacji zredagowanej przez Marię Polok Głusi mówią, sformułowanie to można odnieść do przedstawianych przez piszących problemów. Głusi mówią bowiem o swoich doświadczeniach, potrzebach edukacyjnych ${ }^{23}$. W ich słowach szukać warto odpowiedzi na współcześnie nierozwiązane w Polsce dylematy nie tylko specjalistów, lecz również rodziców niesłyszących dzieci, którzy stoją przed wyborem szkoły i edukacji swojego dziecka. Wybór ten nie jest dziś nadal łatwy, warunkuje go wiele czynników - zarówno wychowanie językowe dziecka, jak i dostępność do określonego typu szkoły oraz preferowany w placówce sposób i metody kształcenia. Opublikowane w tomie wypowiedzi głuchych pokazują zarówno obraz szkoły i edukacji w Polsce, jak i konsekwencje dokonanego wyboru. Konsekwencje, dodajmy, nie tylko edukacyjne, lecz również psychospołeczne.

\section{Szkoła i edukacja szkolna oczyma głuchych}

Zgromadzone wypowiedzi, mimo dzielącego jego dystansu czasowego, pokazują, że jednym z ważniejszych problemów jest doświadczenie związane z kształceniem w szkole ogólnodostępnej (zwanej najczęściej masową ${ }^{24}$ ) i/lub specjalnej (placówkach kształcących osoby głuche ${ }^{25}$ ). Większość osób wskazuje, że doświadczyła zarówno kształcenia w placówce ogólnodostępnej, jak i w szkole dla głuchych. Najczęściej wcześniejszym doświadczeniem jest edukacja w szkole ogólnodostępnej, późniejszym natomiast, związanym z niepowodzeniami edukacyjnymi w szkole „dla słyszących” -

ostatnich 15 lat. Zob. M. Wrześniewska-Pietrzak, Szkoła i edukacja głuchych z perspektywy byłych uczniów [w druku].

${ }^{23}$ Podejmowany tu problem koresponduje z Raportem zespołu ds. Głuchych przy Rzeczniku Praw Obywatelskich pt. Sytuacja osób głuchych w Polsce, Warszawa 2014 (tu zwłaszcza artykuł M. Czajkowskiej-Kisil, A. Siepkowskiej i M. Saka, Edukacja głuchych w Polsce, s. 13-27).

${ }^{24}$ Jest to nazwa funkcjonująca nie tylko potocznie, lecz również obecna w dyskursie naukowym. Zob. m.in. publikacje M. Czajkowskiej-Kisil, A. Klimczewska, Rola języka migowego w kształtowaniu tożsamości Głuchych w Polsce, [w:] E. Woźnicka (red.), Tożsamość społeczno-kulturowa głuchych, Polski Związek Głuchych Oddział Łódzki, Łódź 2007, s. 72-78; M. Świdzińskiego, Jak głusi przyswajaja język: o językach migowych i miganych, [w:] I. Grzesiak (red.), Język migowy we wspótczesnym szkolnictwie na świecie i w Polsce, Stanisław Sumowski, Malbork 2007, s. 16-24; K. Jachimowska, Komunikacyjne aspekty tekstów pisanych przez osoby z dysfunkcją słuchu, Wydawnictwo Uniwersytetu Łódzkiego, Łódź 2013 (tu rozdz. System edukacji niestyszacych (organizacja systemu i metody kształcenia językowego), s. 33-44).

${ }^{25}$ Warto w tym miejscu wskazać, że nazwy placówek nie są jednorodne. Wśród nich są szkoły dla niesłyszących, niedosłyszących i słabosłyszących, a także szkoły dla głuchych. Stosowane są one synonimicznie, choć $\mathrm{w}$ analizowanych wypowiedziach wyraźne są różnice między pojęciem głuchy a słabosłyszący czy niedosłyszący. Zob. więcej: M. Wrześniewska-Pietrzak, Aksjologiczne wyznaczniki tożsamości w wypowiedziach głuchych i czasopiśmie środowiskowym „Świat Ciszy”, Wydawnictwo Rys, Poznań 2017. 
kształcenie w ośrodkach dla głuchych. Zgromadzony materiał wskazuje odrębnie postrzegany obraz szkoły dla niesłyszących i placówek ogólnodostępnych. Szkoła jest dla nich pojęciem, które odrębnie wartościowane jest ze względu na typ placówki i doświadczenia z nią związane.

Szkoła - jak pokazują definicje słownikowe - to leksem posiadający kilka znaczeń. Jest ona bowiem rozumiana jako:

1. instytucja zajmująca się kształceniem, głównie dzieci i młodzieży;

2. siedziba tej instytucji;

3. uczniowie i pracownicy tej instytucji;

4. kurs, na którym uczy się czegoś z konkretnej dziedziny lub zdobywa jakieś umiejętności;

5. wiadomości i umiejętności zdobyte przez naukę w szkole;

6. pot. czas spędzony w szkole na zajęciach;

7. kierunek lub metoda w nauce, sztuce, literaturze itp. mająca wspólne cechy charakterystyczne, oparte na tych samych założeniach;

8. grupa twórców lub naukowców związana z jakąś wybitną osobistością lub pozostająca w kręgu tych samych oddziaływań;

9. sytuacja kształtująca w określony sposób osobowość lub jakieś konkretne ce-

chy człowieka;

10. podręcznik do nauki gry na jakimś instrumencie ${ }^{26}$.

Z uwagi na to, że szkoła wiąże się bezpośrednio z procesem kształcenia, ważny w niniejszym tekście jest również opisywany przez głuchych sposób edukacji. Z analizowanych wypowiedzi wyłania się obraz szkoły postrzeganej głównie jako miejsce, w którym zdobywa się wiedzę przekazywaną przez nauczycieli, a także przestrzeń nawiązywania kontaktów i tworzenia więzi z rówieśnikami. Szkoła jednak szkole nie jest równa. Jak bowiem zauważono, piszący podkreślają wyraźnie typ szkoły, o której piszą. Często też porównują ze sobą różne doświadczenia edukacyjne.

Szkoła jest w zgromadzonym materiale pojęciem nadrzędnym, w obrębie którego funkcjonują dwa profile - szkoły ogólnodostępnej (nazywanej często szkołą dla słyszących ${ }^{27}$ ) i szkoły dla głuchych/niesłyszących i niedosłyszących. W obu kształcenie odbywa się na innych zasadach. W tym miejscu zauważyć trzeba, że oba pojęcia konotują wartościowanie. Szkoła ogólnodostępna, określana jako masowa, wskazuje nie tylko na powszechność edukacji, ale i ilość osób jej podlegających. Wpisuje się zatem w ramy relacji większość - mniejszość, co rzutuje na postrzeganie placówek ogólnodostępnych. Wiąże się także z relacją między słyszącymi a głuchymi. Osoby niesłyszące bowiem z perspektywy słyszącej większości uznawane są jako gorsze,

${ }^{26}$ Hasło „szkoła”. Słownik języka polskiego on-line, http://sjp.pwn.pl/sjp/szkola;2526721.html (dostęp: 2.10.2017). Por. też P. Żmigrodzki (red.). Wielki słownik języka polskiego, http://www.wsjp. pl/index.php?id hasla=15810\&ind=0\&w szukaj=szko\%C5\%82\%C4\%85 (dostęp: 2.10.2017).

${ }^{27} \mathrm{~W}$ zebranym materiale kilkukrotnie pojawia się sformułowanie „szkoła masowa”, co może wynikać z tego, że osoby niesłyszące uznają szkołę ogólnodostępną jako pewnego rodzaju punkt odniesienia, prototypowe rozumienie pojęcia, niewymagające dookreślenia. 
niepełnosprawne, zatem dążenia włączające w obręb większości mogą być uznawane jako próba przynależności do pozytywnie wartościowanej grupy większościowej. Masowość edukacji może też posiadać konotacje negatywne, co wiąże się z niezindywidualizowanym sposobem pracy z uczniem, niedostrzeganiem jednostkowych możliwości i potrzeb.

Natomiast kształcenie w szkole specjalnej, rozumianej jako „szkoła dla dzieci z niedomaganiami fizycznymi, opóźnionych w rozwoju lub nieprzystosowanych społecznie”28 wskazuje, że "gorszość” placówki wynika z deficytów uczniów. Szkoła specjalna staje się szkołą dla tych, którzy nie mogą skończyć szkoły ogólnodostępnej. Powodem tego w potocznej świadomości jest przede wszystkim opóźnienie w rozwoju psychofizycznym, co odzwierciedla też przytoczona definicja słownikowa.

Szkoła ogólnodostępna (najczęściej podstawowa, rzadziej średnia) w wypowiedziach głuchych przedstawiana jest niejednolicie. Piszący najczęściej dostrzegają trudności w nawiązywaniu więzi z rówieśnikami, doświadczają negatywnych zachowań ze strony słyszących kolegów i koleżanek, a ponadto zauważają trudności związane z przyswajaniem wiedzy. Szkoła ogólnodostępna jawi się jako szkoła dla słyszących, w której trudno odnaleźć się osobom niesłyszącym:

W szkole [ogólnodostępnej] nie było już tak dobrze, jak w przedszkolu. Nie miałam koleżanek. Koledzy mi dokuczali. Byłam przeciętną uczennicą. Niczym się nie wyróżniałam Nie miałam żadnych ulg w nauce. Było mi trudno, ale jakoś sobie radziłam (GM, s. 60).

Pomimo to [wady słuchu] posłali mnie [rodzice] do zerówki w szkole masowej w naszej wiosce. Było mi tam bardzo trudno. Niczego nie rozumiałam, nie słyszałam, co się mówi. Okropnie się nudziłam (GM, s. 125).

Sposób waloryzowania szkoły i procesu edukacyjnego wiąże się bezpośrednio z możliwościami komunikacyjnymi piszącego. Osoby, które nie potrafią komunikować się za pomocą języka fonicznego, mają trudności w odbiorze komunikatu zarówno słuchowego, jak i za pomocą odczytywania mowy z ust, podkreślają niemożność lub trudności w nabywaniu wiedzy czy wręcz - jak to pokazuje powyższa wypowiedź - szkoła jest miejscem, w którym niesłyszący się nudzi. Czas spędzony w szkole to czas niewykorzystany, stracony - zarówno z perspektywy edukacyjnej (uczniowie niesłyszący nie zdobywają żadnej wiedzy, z uwagi na bariery komunikacyjne nie są w stanie jej otrzymać), jak i psychospołecznej (nie nawiązują też pozytywnych relacji z rówieśnikami, są często izolowani przez grupę rówieśniczą lub sami się od niej izolują).

Jednakże gdy niesłyszący uczeń wystarczająco sprawnie odczytuje mowę z ust lub jego uszkodzenie słuchu pozwala na funkcjonowanie słuchowe, jego ocena szkoły ogólnodostępnej i obowiązującego w niej sposobu kształcenia zmienia się:

${ }^{28}$ Hasło „szkoła specjalna”, http://sjp.pwn.pl/sjp/szkola-specjalna;2526726.html (dostęp: 2.10.2017). 
Razem ze słyszącymi dziećmi uczęszczałam do zerówki. Czułam się dobrze wśród dzieci słyszących, potrafiłam odczytywać mowę z ust i radziłam sobie w rozmowach. Miałam bardzo miłą koleżankę Anię, która była dla mnie jak przyjaciółka (GM, s. 141).

Placówki kształcące niesłyszących także nie są jednoznacznie wartościowane przez piszących. Najczęściej szkoła ta staje się dla nich miejscem, w którym znajdują akceptację, czują się dobrze, są bowiem wśród osób takich, jak oni.

Babcia i rodzice dowiedzieli się o specjalnej szkole dla niesłyszących w Lublinie. Zapisano mnie do tej szkoły i zamieszkałam w internacie. Pamiętam dokładnie, że babcia bardzo to przeżywała. Widziałam, jak płakała $\mathrm{z}$ tego powodu. A ja czułam się tam dobrze. Przeżyłam tam wspaniałych 9 lat! Mogę powiedzieć, że były to cudowne lata. Moja szkoła była moim domem! Większość czasu przebywałam w internacie i szkole, ale czułam się tam bardzo dobrze pomimo rozłąki z najbliższymi, kochającymi mnie osobami (GM, s. 125).

Po dwóch miesiącach wakacji wróciłam do Raciborza, do wymarzonej przez mnie szkoły [dla osób niesłyszących]. Teraz wszystko wyglądało inaczej. Minął koszmar, lęk, strach, osamotnienie. Tu czułam się dobrze. Czułam, że odnalazłam się na właściwym dla mnie miejscu (GM, s. 117).

Co warte podkreślenia, piszący zauważają, że ich sposób postrzegania szkoły dla niesłyszących często różni się od oceny rodziny. Szkoła dla niesłyszących jest dla słyszących rodziców głuchego dziecka często uznawana jako swego rodzaju piętno, porażka, której doświadczyli jako rodzice czy dziadkowie.

Osoby, które miały możliwość poznania sposobu kształcenia i funkcjonowania w szkole ogólnodostępnej i placówkach kształcących niesłyszących, zauważają, że poziom kształcenia jest w nich różny. Piszący, którzy po doświadczeniach w placówce ogólnodostępnej podjęli edukację w szkole dla niesłyszących, zaznaczają swoje wysokie wyniki w nauce, jednak zauważają zdecydowanie niższy poziom kształcenia. Ceną za komfort bycia akceptowanym jest obniżenie poziomu nauczania.

Gdy podjęłam naukę w klasie szóstej (1974 rok), otwarto we Wrocławiu szkołę dla dzieci niesłyszących i do niej się przeniosłam, choć dotychczasowa wychowawczyni była temu przeciwna. Nie był to szczęśliwy wybór. W szkole tej bardzo mało wymagano. Mało czasu poświęcano na naukę, więcej na wycieczki, spacery i oglądanie telewizji. Bardzo łatwo można było otrzymać oceny bardzo dobre.

Lekarz poradził mi podjęcie nauki w szkole specjalnej dla niedosłyszących, gdzie nauka jest na niższym poziomie i przystosowana do możliwości uczniów. Miałam szansę zdobyć zawód (GM, s. 114-115).

Z nieukończonej klasy siódmej (dla słyszących) przeszłam do klasy ósmej i ukończyłam ją z bardzo dobrymi wynikami. U głuchych są niższe wymagania, inne podejście nauczycieli. Poza tym w szkole dla słyszących było około 30 uczniów w klasie, a tu o połowę mniej (GM, s. 116). 
Przedstawione powyżej wypowiedzi spisane były przez osoby, które znają realia szkolne charakterystyczne dla szkół ogólnodostępnych i specjalnych. Piszący zwracają w nich uwagę na mniejszą liczebność klas w szkołach kształcących głuchych, a ponadto zauważają inne podejście nauczycieli, zrozumienie odmiennego funkcjonowania osób głuchych. Wpływa ono bowiem na cały proces kształcenia.

Jedną z ważniejszych kwestii podejmowanych przez piszących jest stosunek do języka migowego w szkołach dla głuchych. Zwracają oni najczęściej uwagę na to, że nauczyciele dążyli do wykształcenia sprawności mówienia u swoich wychowanków. Dominujące podejście fonocentryczne, a także wychowanie oralistyczne nie było jednak jednoznacznie oceniane negatywnie. Nauczyciele, rodzina, a także sami głusi (także ci urodzeni w rodzinach niesłyszących) byli przeświadczeni, że tylko ten sposób wychowania zapewni samodzielność głuchym żyjącym w dominującej społeczności słyszących.

W szkole moją nauczycielką i wychowawczynią była Pani Teresa Tomczak. To była wyjątkowa pani. Uczyła nas pisania pierwszych liter, uczyła mowy. Nie pozwalała nam migać, wymagała od nas uważnego słuchania, mówienia na głos i odczytywania mowy z ust. Zakładaliśmy aparaty słuchowe i uczyliśmy się rozumieć mowę. Kto pierwszy rozumiał dane słowo, podnosił rękę i je powtarzał. To było bardzo trudne, ale nasza pani potrafiła nam naukę urozmaicać, co nas zachęcało do pracy (GM, s. 148).

Bardzo pomogła mi szkoła dla głuchoniemych. Najpierw uczęszczałam do szkoły dla słyszących, ale niczego nie zdołałam się tam nauczyć poza pisaniem bez rozumienia treści. Nie rozumiałam mowy i sama nie potrafiłam wypowiedzieć żadnej głoski. Po kilku latach rodzice dowiedzieli się o szkole specjalnej dla głuchoniemych w Bydgoszczy. Niestety był to czas okupacji i szkoła niemiecka. Pamiętam, że był to rok 1944, po Wielkanocy. Miałam wówczas 10 lat i zostałam przyjęta do I klasy. Dzięki fachowej pomocy nauczycielki bardzo szybko nauczyłam się abecadła. Mozolnie uczyła mnie przed lustrem poszczególnych głosek, a potem wyrazów. [...] Jestem ogromnie wdzięczna szkole, dzięki której nie zostałam analfabetką. Lubię dużo czytać. To mi pomaga i zastępuje rozmowy. W domu posiadam wiele książek [...] (GM, s. 128).

Szkoła dla głuchych w kilku wypowiedziach okazuje się miejscem nieprzyjaznym, niezrozumiałym, komunikacyjnie niedostępnym dla tych osób niesłyszących, które wychowywane przez słyszących rodziców nie miały możliwości poznać języka migowego:

Razem ze słyszącymi dziećmi uczęszczałam do zerówki. Czułam się dobrze wśród dzieci słyszących, potrafiłam odczytywać mowę z ust i radziłam sobie w rozmowach. Miałam bardzo miłą koleżankę Anię, która była dla mnie jak przyjaciółka. Do Szkoły Podstawowej dla Słabosłyszących i Niesłyszących uczęszczałam w Otwocku Śródborowie. Nie podobało mi się to, że wszyscy tam posługiwali się językiem migowym, a ja go nie znałam. Nie chciałam się uczyć tego dziwnego języka. Marzyłam o szkole dla słyszących (GM, s. 141). 
Większość dzieci przebywała w szkole i internacie od poniedziałku do piątku. Nie miałam z nimi dobrego kontaktu i nie byłam zadowolona z takiego systemu nauczania (GM, s. 60-61).

Niezrozumienie wywołuje też oddalenie od rodziny, rozłąka, która w przypadku wielu niesłyszących uczniów jest konieczna. Uczący się w szkołach z internatem wracają do swych domów na weekendy, a czasem nawet rzadziej. Dla osób, które nie znają języka migowego, społeczności szkolnej, rozłąka ta jest dużym przeżyciem, często niezrozumiałym.

Mimo że większość zgromadzonych wypowiedzi dotyczy kształcenia w szkołach podstawowych i średnich, w publikacji Głusi mówia zamieszczony został tekst jednego z młodszych autorów, który zwrócił uwagę na kształcenie wyższe. Nie było ono tak częste w środowisku głuchych jak dziś, kiedy to coraz więcej osób niesłyszących podejmuje naukę na studiach. Z tego też powodu studiowanie postrzegane jest jako duża wartość. Przekonują o tym opisane przez piszącego emocje towarzyszące zarówno zdawaniu matury, jak i pozytywnemu wynikowi egzaminów wstępnych:

Do matury podchodziłem w maju 2004 roku. Strasznie to przeżywałem, bałem się i denerwowałem. Z niecierpliwością czekałem na wyniki. Gdy dowiedziałem się, że zdałem, rozpłakałem się z radości. [...] Dyrektorka Agata Tańska namawiała mnie i moją dziewczynę - Magdę [także niesłyszącą], do podjęcia studiów w Państwowej Wyższej Szkole Zawodowej w Raciborzu. Znowu obawiałem się, czy sprostam takiemu zadaniu. Po przemyśleniu zdecydowaliśmy się na dalszą edukację. [...] Podobnie jak po maturze - po ogłoszeniu pozytywnych wyników egzaminu i przyjęciu na studia płakaliśmy z radości (GM 46).

System kształcenia na studiach nie był również dostosowany do możliwości komunikacyjnych osób głuchych. Piszący pokazuje bowiem trudności związane z niemożnością odczytywania mowy z ust wykładających akademików, a także problemy z jednoczesnym notowaniem i odbieraniem wzrokowym komunikatu. Co ważne, wskazuje on na możliwość dostosowania systemu kształcenia do potrzeb osób głuchych komunikujących się za pomocą języka migowego. Podkreśla rolę tłumacza języka migowego, a także pomoc koleżeńską, która dziś często na uczelniach wyższych gwarantowana jest poprzez zapewnienie studentom asystenta.

Na początku było bardzo trudno: nowe środowisko, nowi ludzie, wszyscy słyszący. Bardzo baliśmy się tego, jak sobie poradzimy. Wykładowcy mówili bardzo szybko. Nie byliśmy w stanie patrzeć na usta, odczytać mowę i jednocześnie notować. Spotkaliśmy się jednak z ogromną życzliwością naszych kolegów i koleżanek - studentów, jak i wykładowców. Znalazł się także tłumacz języka migowego! Największe bariery zostały pokonane! (GM, s. 46-47).

Tu jednak również, podobnie jak na wcześniejszych etapach kształcenia, możliwość edukacji zależy od sprawności komunikacyjnych zarówno uczącego się, jak i nauczającego, a także przygotowania całego procesu dydaktycznego z uwzględnieniem potrzeb ucznia/studenta niesłyszącego. 


\section{Wnioski}

Wyłaniający się z analizowanych wypowiedzi obraz szkoły i edukacji osób niesłyszących zależny jest od podmiotu postrzegającego, jego doświadczeń, a także przyjętej perspektywy oglądu. Piszący, którzy doświadczyli edukacji w szkole ogólnodostępnej, a także specjalnej, oceniali obie instytucje niejednoznacznie. Ważna była dla nich akceptacja grupy społecznej, którą często niemal automatycznie osiągali wśród rówieśników niesłyszących. Związana ona była najczęściej z możliwościami komunikacyjnymi piszącego, a także grupy szkolnej, do której aspirował, której częścią chciał być. Wypowiadający się $\mathrm{w}$ tomie Polok głusi dostrzegali jednak niższy poziom kształcenia w placówkach dla niesłyszących, zwracali uwagę na to, że częste było w nich fonocentryczne i oralistyczne podejście do kształcenia języka, co wiązało się z wieloma ćwiczeniami zmierzającymi do usprawnienia komunikacji w języku polskim (zwłaszcza w mowie).

Nieliczne osoby pozytywnie postrzegały swoją edukację w szkołach ogólnodostępnych. Byli to najczęściej głusi, którzy korzystali z aparatów słuchowych pozwalających im dobrze funkcjonować w społeczności słyszących komunikujących się językiem fonicznym. Najczęściej osoby te nie znały dobrze (lub nie znały wcale) języka migowego. Przeniesione do szkół dla niesłyszących doświadczały obcości, odrzucenia, nie potrafiły znaleźć swojego miejsca w grupie rówieśniczej. Postawy te wiązać można także ze stereotypowym postrzeganiem osób niesłyszących jako gorszych, co powodowało dążenie do integracji ze społecznością słyszącą.

Analiza wypowiedzi zebranych w książce Głusi mówia przekonuje, że remedium na kształcenie niesłyszących to nie wybór jednej najlepszej metody. Dążenie do takich rozwiązań jest bezcelowe, ponieważ niejednorodność językowa głuchych sprawia, że wypracowanie jednego modelu kształcenia w realiach polskich nie jest możliwe. Piszący mieli niejednorodne oczekiwania związane z własnym kształceniem, które przedstawiali na zasadzie opozycji: szkołą ogólnodostępna - szkoła specjalna. Uczniowie „funkcjonalnie słyszący" ${ }^{\text {"29 }} \mathrm{w}$ placówkach ogólnodostępnych oczekiwali nie odmiennego traktowania, lecz dostosowania metod pracy do swoich możliwości percepcyjnych (stosowania materiałów odwołujących się do zmysłu wzroku, organizacji zajęć i przestrzeni sali lekcyjnej, która umożliwiłaby pełne uczestnictwo w zajęciach osobie niesłyszącej). Natomiast głusi kształceni w placówkach specjalnych zwracali uwagę na łatwość komunikacyjną. Nie chcieli ułatwień, okrojonego programu pracy. Cenili to, że szkoła dawała im komfort psychiczny w postaci akceptacji ze strony nauczycieli i grupy rówieśniczej, jako wadę wskazywali nieadekwatny do swoich możliwości poziom kształcenia.

${ }^{29}$ Określenie to w swojej klasyfikacji osób niesłyszących stosuje K. Krakowiak, Dar języka. Podręcznik metodyki wychowania językowego dzieci i młodzieży z uszkodzeniami narząd słuchu, Wydawnictwo KUL, Lublin 2012, s. 104. 
Co ważne - jak pokazuje wypowiedź jedynego młodego studenta wśród piszących - pozytywny obraz edukacji był w ówczesnych czasach możliwy. W jego ramy wpisuje się szkoła (placówka, społeczność szkolna), która potrafiłaby dostosować metody kształcenia do potrzeb swoich uczniów. Przedstawiony przez studenta proces adaptowania się do kształcenia na uczelni wyższej wiązał się z wprowadzaniem kolejnych udogodnień - pomocy koleżeńskiej, a dalej tłumacza języka migowego. Udogodnienia te, co w tym miejscu trzeba mocno podkreślić, nie były i nie powinny być realizowane poprzez obniżanie poziomu edukacji, lecz właśnie dostosowania sposobów i metod kształcenia do ucznia/studenta. Głusi, których wypowiedzi zebrała Maria Polok i opublikowała w 2008 roku, są świadomi tego, że edukacja oferowana im w szkołach dla głuchych nie była (i nadal nie jest) taka sama jak w szkołach ogólnodostępnych. Walcząc z trudnościami napotykanymi w szkołach ogólnodostępnych, walczyli tak naprawdę o swoją edukację.

Podejmowana dziś dyskusja na temat kształcenia osób niesłyszących w Polsce stanowi pewnego rodzaju odpowiedź na wyrażane przez głuchych oczekiwania względem ich edukacji. Wskazując walory i wady obu systemów kształcenia, autorzy tekstów opublikowanych w tomie Głusi mówią zabierają głos w tej właśnie dyskusji. Jest on niezwykle ważny. Przedstawia nie tylko obraz szkoły i sposobów edukacji niesłyszących, lecz - co ważniejsze - pokazuje, że głuchy to osoba, która chce się uczyć, chce zdobywać wiedzę, stanowi ona dla niego jedną z wartości poznawczych pozwalających człowiekowi na rozwój, a także zaspokojenie ciekawości świata.

\section{Bibliografia}

Bouvet D., Mowa dziecka. Wychowanie dwujęzykowe dziecka niesłyszącego, Wydawnictwa Szkolne i Pedagogiczne, Warszawa 1996.

Butkiewicz A., Czajkowska-Kisil M., Głusi i nie(do)słyszacy na uczelni wyższej, [w:] M. Świdziński (red.), Sytuacja osób głuchych w Polsce. Raport zespołu ds. Głuchych przy Rzeczniku Praw Obywatelskich, Biuro Rzecznika Praw Obywatelskich, Warszawa 2014.

Czajkowska-Kisil M., Klimczewska A., Rola języka migowego w kształtowaniu tożsamości, [w:] E. Woźnicka (red.), Tożsamość społeczno-kulturowa głuchych, Polski Związek Głuchych Oddział Łódzki, Łódź 2007.

Czajkowska-Kisil M., Siepkowska A., Sak M., Edukacja głuchych w Polsce, [w:] M. Świdziński (red.), Sytuacja osób głuchych w Polsce. Raport zespołu ds. Głuchych przy Rzeczniku Praw Obywatelskich, Biuro Rzecznika Praw Obywatelskich, Warszawa 2014.

Jachimowska K., Komunikacyjne aspekty tekstów pisanych przez osoby z dysfunkcja słuchu, Wydawnictwo Uniwersytetu Łódzkiego, Łódź 2012. 
Januszewicz M., Jura M., Kowal J., Każdy ma prawo do nauki. Prawo głuchych do dostępu do języka i edukacji, [w:] M. Sak (red.), Edukacja głuchych, Biuro Rzecznika Praw Obywatelskich, Warszawa 2014.

Krakowiak K., Dar języka. Podręcznik metodyki wychowania językowego dzieci i młodzieży z uszkodzeniami narząd słuchu, Wydawnictwo KUL, Lublin 2012.

Podgórska-Jachnik D., Głusi. Emancypacje, Wydawnictwo Naukowe Wyższej Szkoły Pedagogicznej w Łodzi, Łódź 2013.

Podgórska-Jachnik D., Historia wychowania i edukacji głuchych z perspektywy surdopedagogiki początku XXI wieku, [w:] J. Błeszyński, D. Baczała, J. Binnebesel (red.), Historyczne dyskursy nad pedagogika specjalna, Wydawnictwo Naukowe Wyższej Szkoły Edukacji Zdrowotnej, Łódź 2008.

Polok M. (red.), Głusi mówią, Baterex Jan i Kazimierz Kwaśniewicz, Racibórz 2008.

Rutkowski P., Talipska M., Kształcenie akademickie głuchych, M. Sak (red.), Edukacja głuchych, Biuro Rzecznika Praw Obywatelskich, Warszawa 2014.

Sak M., Kształcenie głuchych w szkołach masowych $i$ w klasach mieszanych z innymi niepetnosprawnościami, M. Sak (red.), Edukacja głuchych, Biuro Rzecznika Praw Obywatelskich, Warszawa 2014.

Słownik języka polskiego PWN on-line, http://sjp.pwn.pl (dostęp: 2.10.2017).

Sytuacja osób głuchych w Polsce. Raport zespołu ds. Głuchych przy Rzeczniku Praw Obywatelskich, Biuro Rzecznika Praw Obywatelskich, Warszawa 2014.

Szczepankowski B., Niesłyszacy - głusi - głuchoniemi. Wyrównywanie szans, Wydawnictwa Szkolne i Pedagogiczne, Warszawa 1999.

Świdziński M., Fabisiak S., Dwujęzyczność - zagrożenie, wyzwanie, jedyna szansa, „Audiofonologia” 2010, t. 26, s. 15-19.

Świdziński M., Jak głusi przyswajaja język: o językach migowych i miganych, [w:] I. Grzesiak (red.), Język migowy we współczesnym szkolnictwie na świecie i w Polsce, Stanisław Sumowski, Malbork 2007.

Tomaszewski P., Polski język migowy (PJM) - mity i fakty, „Poradnik Językowy”, nr 6/2004, s. 59-72.

Wiśniewska A., Egzaminy zewnętrzne a uczniowie z wadą słuchu - studium przypadku, Polski Związek Głuchych Oddział Łódzki, Łódź 2016.

Wrześniewska-Pietrzak M., Aksjologiczne wyznaczniki tożsamości w wypowiedziach głuchych i czasopiśmie środowiskowym „Świat Ciszy”, Wydawnictwo Rys, Poznań 2017.

Wrześniewska-Pietrzak M., Szkoła i edukacja głuchych z perspektywy (byłych) uczniów [w druku].

Wzorek A., Rodzina z dzieckiem z zaburzeniami słuchu - spojrzenie systemowe, „Psychoterapia", nr 4(151)/2009, s. 53-64.

Żmigrodzki P. (red.), Wielki słownik języka polskiego, http://www.wsjp.pl (dostęp: 2.10.2017). 


\title{
A picture of school and the education of deaf students in Poland derived from texts written by deaf adults
}

Abstract: The aim of this article is to present ways of evaluating the educational experience of deaf students who graduated from ordinary schools and special schools for the deaf. The first part of this article indicates the ways of educating deaf people in Poland in the past and nowadays. The analysed texts were written in Polish by deaf adults. The educational system described by deaf people is typical for the educational system of the 1980s and 1990s. The deaf authors of the analysed texts describe the problems and consequences of the oral method of education. Their remarks are similar to aspects discussed by academics and specialists concerned about the ways of educating deaf students in Poland today.

Keyword: deaf education, history of deaf education in Poland

\begin{abstract}
About the authors: Karolina Ruta-Korytowska - PhD of contemporary linguistics, assistant professor at the Institute of Polish Philology at the Adam Mickiewicz University, lector of Polish as a foreign language. Currently, the subject of her research is Polish sign language and methodology of teaching people with hearing dysfunction of Polish as a foreign language. Winner of the 5th Majer Bałaban Competition for the best doctoral and master thesis on Jewish topics, organized by the Jewish Historical Institute E. Ringelblum and the Arthur Rojszczak granted by the Scholarship Club of the Foundation for Polish Science.

Marta Wrześniewska-Pietrzak - PhD of contemporary linguistics, assistant professor at the Institute of Polish Philology at the Adam Mickiewicz University; current research interests focus on the problems of identity of deaf people in Poland, teaching Polish as a foreign language to deaf and teaching Polish Sign Language to hearing people, as well as semantics in linguistics and axiolinguistics; autor of two books: Aksjologiczne wyznaczniki tożsamości w wypowiedziach głuchych i czasopiśmie środowiskowym „Świat Ciszy” (2017) and „Miało być odlotowo, czadowo, bojowo...”. Język i świat wartości czasopism szkolnych na tle pism młodzieżowych (2012).
\end{abstract}




\title{
Pedagogika wobec schizofrenii
}

\begin{abstract}
Streszczenie: Niniejszy artykuł jest głosem w dyskusji nad zmianami w pedagogice specjalnej. Jego celem jest wykazanie potrzeby dalszego włączania schizofrenii w obszar tej nauki. W pierwszym podrozdziale autorka przybliża schizofrenię i jej skutki psychospołeczne. Uzasadnia konieczność wszechstronnego i interdyscyplinarnego wsparcia procesu terapeutycznego i przedstawia podstawowe założenia psychiatrii środowiskowej. W kolejnym podrozdziale omawia teoretyczne założenia pedagogiki specjalnej - historyczny zarys, cele, subdyscypliny, podmioty, przedmiot oraz charakter podejmowanych działań. W ostatnim podrozdziale autorka wykazuje, że schizofrenia może być rozumiana jako niepełnosprawność, zaś włączenie jej w nurt pedagogiki specjalnej nie zmieni charakteru dyscypliny. Dodatkowo wykazuje możliwe drogi rozwoju pedagogiki specjalnej - stworzenie nowej subdyscypliny lub rozszerzenie pedagogiki terapeutycznej.
\end{abstract}

Słowa kluczowe: pedagogika specjalna, psychiatria środowiskowa, schizofrenia, niepełnosprawność, pedagogika terapeutyczna, inkluzja, wsparcie

\section{Wprowadzenie}

Niniejszy artykuł jest głosem w dyskusji dotyczącej koniecznych zmian w pomocy i wsparciu oferowanym osobom chorującym na schizofrenię - tak ważnych wobec niepokojącego wzrostu skali zaburzeń psychicznych we współczesnym świecie. Zostaną w nim przedstawione podstawy teoretyczne dotyczące: choroby jaką jest schizofrenia, wsparcia psychospołecznego, jakie jest potrzebne i konieczne, aby osoby chorujące mogły funkcjonować $\mathrm{w}$ społeczeństwie, w końcu potencjalnej roli pedagogiki i pedagogiki specjalnej w udzielaniu tego wsparcia. Analiza ta odnosi się również do współczesnego ujęcia pedagogiki specjalnej i jej podmiotu (podmiotów), przedmiotu oraz działań, jakie są podejmowane wobec osób z niepełnosprawnościami. Celem

* Monika Banaszczyk - absolwentka Uniwersytetu Łódzkiego, psycholog, doktorantka studiów pedagogicznych na Uniwersytecie Kazimierza Wielkiego w Bydgoszczy. Jej publikacje dotyczą pedagogiki specjalnej, schizofrenii, niepełnosprawności, osobowości, stygmatyzacji. 
artykułu jest wykazanie, że dotychczasowa reprezentacja problematyki schizofrenii jak również innych chorób psychicznych - w obszarze problemowym pedagogiki specjalnej nie jest jak dotąd wystarczająca, z punktu widzenia nowoczesnego podejścia terapii środowiskowej osób z tymi chorobami, choć rola pedagoga specjalnego w modelu takiej terapii może być bardzo duża. Konieczne jest zatem rozbudowanie zarówno refleksji teoretycznej, jak i przygotowanie praktyczne pedagogów specjalnych do spotkania z osobą chorującą na schizofrenię oraz osobą zdrowiejącą. Włączenie problematyki schizofrenii w obszar pedagogiki specjalnej jest kolejnym etapem jej rozwoju, wynikającym z potrzeby praktyki, jednocześnie nie narusza tożsamości tej nauki: niezagospodarowane dotąd miejsce dla osób ze schizofrenią wpisuje się znakomicie w obszar jej subdyscypliny - pedagogiki terapeutycznej. Co więcej, choć zagadnienia obejmują problematykę osób chorych, nie oznaczają negatywnie wartościowanej obecnie przez pedagogikę specjalną medykalizacji. Przeciwnie: są wyrazem humanistycznego spojrzenia na człowieka w chorobie oraz uspołecznienia podejścia terapeutycznego.

\section{Schizofrenia i jej skutki psychospołeczne}

Schizofrenia to choroba, która początkowo była nazywana wczesnym otępieniem ${ }^{1}$ oraz była uznawana za przyczynę postępującej degradacji psychicznej. Nazwa została wprowadzona na początku XX w. i oznaczała rozszczepienie umysłu, rozumiane jako brak więzi między nim a emocjami oraz światem zewnętrznym² ${ }^{2}$. Dziśs schizofrenia jest określana jako „zaburzenie myślenia, w którym umiejętność rozpoznawania rzeczywistości, reakcje emocjonalne, procesy myślenia, formułowanie sądów oraz umiejętność porozumiewania się pogarszają się tak bardzo, że funkcjonowanie chorej osoby jest poważnie utrudnione"3. Najczęściej ujawnia się między 16 a 35 rokiem życia, dlatego bywa nazywana „chorobą młodych”. Rzadziej mamy do czynienia ze schizofrenią występującą u dzieci - pojawia się przed 10 rokiem życia - i tak zwaną późną - po 50 roku życia ${ }^{4}$. Badacze zauważają, że nie można spotkać ani jednej wspólnej cechy, która by wstępowała u każdej z chorujących osób. Początek, czyli wiek zachorowania oraz dynamika rozwoju schizofrenii, czas trwania, rodzaj zaburzeń związanych z procesami poznania poznawczego, emocjami, osobowością czy zaburzeniami mo-

\footnotetext{
${ }^{1}$ A.M. Colman, Słownik psychologii, Wydawnictwo Naukowe PWN, Warszawa 2009.

2 R.C. Carson, J.N. Butcher, S. Mineka, Psychologia zaburzeń, t. 2, Gdańskie Wydawnictwo Psychologiczne, Gdańsk 2003.

${ }^{3}$ Ch. Frith, E. Johnstone, Schizofrenia, GWP, Gdańsk 2012, za: R. Warner, Recovery from schizophrenia: psychiatry and political economy, Routledge, London 1994.

${ }^{4}$ K.T. Mueser, S. Gingerich, Życie ze schizofrenią. Poradnik dla rodzin, Dom Wydawniczy REBIS, Poznań 2008.
} 
torycznymi - różnią się, niekiedy znacznie, u większości, a nawet u każdej z osób ${ }^{5}$. Jednakże naukowcy podkreślają, że różnorodne objawy mogą występować u jednego chorującego w kolejnych okresach choroby ${ }^{6}$.

Schizofrenia jest chorobą niejednolitą i nie obejmuje wyłącznie jednego rodzaju objawów, termin ten obejmuje wiele jej rodzajów, zaś pacjentów można przypisać do jednego $\mathrm{z}$ nich, a są to:

- schizofrenia katatoniczna: objawiająca się zastygnięciem - katatonią lub nadmiernymi, chaotycznymi ruchami; pacjentowi towarzyszy w niej silne poczucie lęku; występuje mowa rozkojarzona i negatywizm czynny i bierny, czyli opór lub poddawanie się aktywności;

- schizofrenia prosta: powiązana jest z narastaniem obojętności i obniżenia nastroju; pojawia się zaniedbywanie obowiązków i coraz większe odosobnienie; zachowania stają się stereotypowe i jednocześnie ciężko jest chorującego namówić do zmiany;

- schizofrenia paranoidalna: osobie chorującej brakuje umiejętności opisu własnych przeżyć; obecne są: omamy, urojenia, które mogą mieć charakter prześladowczy lub wielkościowy oraz hiperfunkcja spostrzegawczości, czyli zauważanie szczegółów, które nie występuje u osób zdrowych ${ }^{7}$;

- schizofrenia hebefreniczna: objawiająca się spłyceniem afektu oraz nieadekwatnymi reakcjami emocjonalnymi; zachowanie chorego jest nieprzewidywalne; niekiedy mogą występować w niej manieryzmy;

- schizofrenia zdezorganizowana: przejawia się zdezorganizowaną mową i zachowaniem oraz nieadekwatnymi reakcjami emocjonalnymi ${ }^{8}$; obecne są w niej manieryzmy; może prowadzić do dezorganizacji osobowości;

- schizofrenia niezróżnicowana: związana jest ze zmieniającą się mieszaniną podstawowych objawów ${ }^{9}$, lecz nie można jej przypisać do innej postaci schizofrenii;

- schizofrenia rezydualna: z początku występują w niej objawy psychotyczne, a następnie negatywne;

- schizofrenia innego rodzaju: są to zaburzenia o postaci schizofrenii;

- depresja poschizofreniczna: epizod depresyjny, który występuje po chorobie schizofrenicznej; objawy schizofrenii są jeszcze obecne, ale dominuje depresja ${ }^{10}$.

Choć to tylko podstawowa klasyfikacja, przedstawiona w celach orientacyjnych, ukazuje ogromną złożoność fenomenu tej choroby. Może też uzasadniać dotychczasowy dystans nauk pedagogicznych do obszaru kojarzonego głównie z działaniami

${ }^{5}$ G. Zalewski, Kontrowersje wokót schizofrenii. Świadomość zdrowych i chorych, Trans Humana, Białystok 2001.

${ }^{6}$ Ch. Frith, E. Johnstone, dz. cyt.

7 A. Kępiński, Schizofrenia, Wydawnictwo Literackie, Kraków 2011.

${ }^{8}$ A.M. Colman, dz. cyt.

9 R.C. Carson i in., dz. cyt.

${ }^{10}$ S. Pużyński, J. Wciórka, Klasyfikacja zaburzeń psychicznych i zaburzeń zachowania w ICD-10, Uniwersyteckie Wydawnictwo Medyczne VESALIUS, Kraków 2000. 
psychiatrów, czasem także psychologów klinicznych, choć życie z chorobą, adaptacja społeczna, perspektywy rozwojowe i samorealizacja w kontekście weryfikowanych przez chorobę planów życiowych - wydaje się jednak domeną pedagogiki. Do tego problem dotyczy wcale niemałej populacji. Raport EZOP (Epidemiologia Zaburzeń Psychiatrycznych i Dostępność Psychiatrycznej Opieki Zdrowotnej) z przeprowadzonej w 2012 roku, pierwszej rzetelnej ogólnopolskiej analizy chorobowości związanej z zaburzeniami psychicznymi, przyniósł niepokojące dane ${ }^{11}$. „Badanie wykazało, że w Polsce przynajmniej jedno z zaburzeń psychicznych objętych klasyfikacjami ICD-10 i DSM-IV ${ }^{12}$ można rozpoznać w ciągu życia u $23,4 \%$ populacji. Oznacza to, że dotkniętych nimi jest około sześć milionów mieszkańców Polski w wieku produkcyjnym. Spośród nich co czwarta osoba cierpiała przynajmniej na dwa rodzaje zaburzeń, a co dwudziesta piąta - na trzy i więcej. Przynajmniej trzy rodzaje zaburzeń występują u około ćwierci miliona osób w Polsce"13. Badania przeprowadzono na próbie 10 tys. osób w wieku 18-64 lat. Wyniki z badań populacji dzieci, młodzieży i seniorów mogłyby jeszcze podnieść te wskaźniki. Występowanie schizofrenii dotyczy ok. $1 \%$ populacji ${ }^{14}$. Jednakże badania wykazują wzrost rozpoznań objawów psychotycznych $(5 \%)$ oraz szeroko rozumianych doświadczeń psychotycznych $(15 \%)^{15}$. Mimo iż wskaźniki niektórych innych chorób i zaburzeń psychicznych mogą być wyższe (np. zaburzenia lękowe dotyczą ok. 10\% populacji, zaburzenia nastroju - afektywna jedno- i dwubiegunowe - ok. 3,5\%), zdaniem Doroty Podgórskiej-Jachnik i Tadeusza Pietrasa - to jednak schizofrenia jest chorobą wymagającą największego wsparcia społecznego. Autorzy wskazują bowiem na znaczącą utratę zdolności adaptacyjnych, prowadzącą - co w niewielkim stopniu uświadamia sobie społeczeństwo - nie tylko do pogorszenia jakości życia, ale także do znacznego jego skrócenia, nawet o kilkanaście lat. Autorzy uważają, iż dzieje się tak z powodu:

- zaniedbań opieki wobec chorych;

- deficytu samoopieki, wyrażającego się brakiem dbałości o własne zdrowie, jako konsekwencji objawów psychotycznych i deficytów funkcji poznawczych;

- samotności i braku partnerów życiowych;

- zaburzeń polekowych (m.in. cukrzycy typu II, zespołu metabolicznego, zaburzeń kadriologicznych);

${ }^{11}$ Epidemiologia zaburzeń psychiatrycznych i dostępność psychiatrycznej opieki zdrowotnej EZOP - Polska, http://www.ezop.edu.pl [dostęp: 8.05.2018].

${ }^{12}$ Obecnie nieco zmienione kryteria diagnostyczne przedstawiają już nowe klasyfikacje ICD-11 i DSM-5, nie wydaje się to jednak zmieniać zasadniczo skali zjawiska, stąd cytowane uwagi są nadal aktualne.

${ }^{13}$ Za: D. Podgórska-Jachnik, T. Pietras, Praca socjalna z osobami z zaburzeniami psychicznymi i ich rodzinami, Centrum Rozwoju Zasobów Ludzkich, Warszawa 2014, s. 45.

${ }^{14} \mathrm{~J}$. Wciórka, Psychozy schizofreniczne, [w:] S. Pużyński, J. Rybakowski, J. Wciórka, Psychiatria. Psychiatria kliniczna, t. 2, Elsevier Urban \& Partner, Wrocław 2011, s. 195-269.

15 A.T. Beck, N.A. Rector, N. Stolar, P. Grant, Schizofrenia w ujęciu poznawczym. Teoria, badania i terapia, Wydawnictwo Uniwersytetu Jagiellońskiego, Kraków 2010. 
- stygmatyzacji chorych na schizofrenię (co można poszerzyć także na ich najbliższe otoczenie) oraz lęku społecznego przed kontaktami z nimi;

- antyzdrowotnych nawyków, w tym niskiej aktywności ruchowej i rozpowszechnienia palenia tytoniu wśród tych chorych (nawet $80 \%$ palaczy) ${ }^{16}$.

Spektrum objawów i zaburzeń, z jakimi na co dzień żyją osoby chorujące, jest bardzo szerokie, czego nie wyczerpała przedstawiona wcześniej klasyfikacja. Należą do nich:

- symptomy pozytywne, zwane też zaburzeniami funkcjonalnymi: halucynacje, urojenia dotyczące myślenia dedukcyjnego i indukcyjnego, zdezorganizowana mowa na poziomie myśli i języka, problemy z kontrolą zachowania i aktywności motorycznej;

- symptomy negatywne, zwane ograniczeniami funkcjonalnymi: alogia, zaburzenia płynności mowy i myślenia, stępienie i zubożona ekspresja emocjonalna, bierność na poziomie motywacji i popędów, anhedonia związana z nowymi czynnościami, jak również tymi, które kiedyś sprawiały przyjemność, aspołeczność związana z doświadczaniem związków emocjonalnych z innymi osobami, problemy z koncentracją uwagi ${ }^{17}$, niemożność segregacji i przetwarzania dużej ilości informacji;

- zaburzenia myślenia: powiązane z zabieraniem, nasyłaniem, pochodzeniem myśli z innego miejsca w ciele;

- zaburzenia tożsamości;

- zmiany w zachowaniu: od nieznaczących po drastyczne - niekiedy rodzina uważa, że chorujący jest inną osobą niż ta osoba sprzed choroby;

- zaburzenia ruchowe: całkowite ograniczenie lub nadpobudliwość;

- ucieczka do własnego, wewnętrznego świata, który jest nielogiczny ${ }^{18}$;

- agresja: wobec siebie i innych;

- depresja;

- lęk $\mathrm{k}^{19}$.

Pacjenci spotykają się również z szeregiem problemów, które są efektem wcześniej wymienionych objawów. Są to tak zwane zaburzenia wtórne i dotyczą sfer:

- społecznej - jest ona związana z brakiem zatrudnienia, niepowodzeniem lub degradacją społeczną, instytucjonalizacją, zubożeniem kontaktów społecznych, rozpadem rodziny lub odrzuceniem, uprzedzeniami, które wynikają ze stereotypów;

- psychicznej - która powiązana jest z brakiem pewności siebie i motywacji do działania, zaburzeniami umiejętności pozwalających na przetrwanie społeczne

${ }_{16}$ D. Podgórska-Jachnik, T. Pietras, dz. cyt.

${ }_{17}$ G. Zalewski, dz. cyt., za: J. Strauss, W. Carpenter, J. Bartko, The diagnosis an understanding of schizophrenia. Part III, „Schizophrenia Bulletin”, no. 11/Winter1974.

${ }_{18}$ R.C. Carson i in., dz. cyt.

19 A. Witusik, S. Leszto, D. Podgórska-Jachnik, T. Pietras, Schizofrenia w kontekście nauk społecznych. Osoba chora na schizofrenię w obszarze zainteresowań pedagogiki specjalnej, Wydawnictwo Continuo, Wrocław 2015. 
i środowiskowe, zależnością od rodziny lub instytucji pomagających, cierpieniem związanym z objawami choroby ${ }^{20}$;

- ekonomicznej - która jest efektem trudności w wymienionych poprzednio sfe$\operatorname{rach}^{21}$.

Dodatkowo, osoby chorujące, mają niekiedy problemy z utrzymaniem czystości i higieny osobistej ${ }^{22}$ oraz bardzo często dotyka ich wspomniana już stygmatyzacja i/ lub autostygmatyzacja ${ }^{23}$. Chociaż naznaczenie społeczne nie wynika bezpośrednio z samej choroby - jest skutkiem wtórnym - to jednak walka ze stygmatyzacją osób chorujących psychicznie wydaje się największym wyzwaniem. Jego podjęciu sprzyja m.in. oderwanie się od tradycyjnego modelu psychiatrii, na rzecz terapii środowiskowej, zakładającej możliwość ponownego, aktywnego włączenia jednostki do społeczeństwa.

Osoba chorująca na schizofrenię nie jest bowiem skazana wyłącznie na negatywne skutki choroby. Humanistyczne i uspołecznione podejście poszukuje rozwiązań stwarzających inne szanse niż ciągłe hospitalizacje i farmakoterapia przez całe życie. Coraz częściej dowodzi się, że rozpoznanie choroby nie musi oznaczać niesamodzielnego, jałowego życia, w którym nie ma przyjemności, osiągnięć, rozwoju. Najlepszym przykładem jest Elyn Saks, która opisała historię swojego życia z tą chorobą ${ }^{24}$. Przeżycia autorki oraz wielu innych osób, które pokazują, że mogą prowadzić życie pełne, bez wyrzeczeń, są potwierdzeniem, jak ważna jest pomoc i wsparcie w efektywnym radzeniu sobie z chorobą. Coraz częściej też pojawia się w pewnej fazie choroby psychicznej optymistyczny i zasadny termin: „osoba zdrowiejąca”25.

Jak postulują teoretycy oraz praktycy, leczenie schizofrenii powinno odbywać się przede wszystkim wszechstronnie - za pomocą leków, wsparcia i terapii, uwzględniając wszystkie objawy, jakie u danej osoby występują. Zauważają również, że istotna jest wytrwałość w leczeniu, ukierunkowanie na podtrzymanie nadziei na zmniejszenie lub niwelację problemów wynikających z choroby oraz uwzględnianie podmiotowości i indywidualizacji względem każdego pacjenta ${ }^{26}$. Jednocześnie podkreślają znaczenie kontaktów pozarodzinnych, społecznych oraz ich jakości ${ }^{27}$. Dlatego istotne jest przezwyciężanie niedogodności oraz problemów wynikających z nasilania się objawów. Pacjenci wielokrotnie nie potrafią zadbać o siebie, jak również nie wywiązują się z podejmowanych wcześniej zobowiązań. Pełnienie ról społecznych oraz czerpa-

${ }^{20}$ M. Birchwood, Ch. Jackson, Schizofrenia. Modele kliniczne i techniki terapeutyczne, Gdańskie Wydawnictwo Psychologiczne, Gdańsk 2006.

${ }^{21}$ A. Witusik i in., dz. cyt.

22 A.M. Colman, dz. cyt.

${ }^{23}$ A. Witusik i in., dz. cyt.

${ }^{24}$ E.R. Saks, Schizofrenia. Moja droga przez szaleństwo, Burda Publishing Polska, Warszawa 2014.

${ }^{25}$ A. Witusik i in., dz. cyt.

${ }^{26}$ J. Wciórka, dz. cyt.

${ }^{27}$ M. Brichwood, Ch. Jackson, dz. cyt. 
nie radości z nich, niekiedy zdaje się być dla pacjenta nieosiągalne ${ }^{28}$. Dlatego bardzo często opieka typowo medyczna to za mało i osoby chorujące na schizofrenię potrzebują wsparcia zespołu terapeutycznego, na który powinni składać się: lekarz, psycholog kliniczny, pielęgniarz/pielęgniarka, pracownik socjalny, pedagog ${ }^{29}$. Co więcej, wsparcia wymaga też rodzina chorego - by sama nie uległa dezintegracji i by mogła skuteczne wspierać osobę chorującą. Interdyscyplinarna współpraca jest jednym z postulatów zwolenników psychiatrii społecznej i środowiskowej. Według nich istotne jest również włączenie w proces terapii rodziny osoby chorującej, zaś organizacja oraz przebieg działań pomocowych powinny wykorzystywać zasoby środowiska lokalnego. Celem tak rozumianej psychiatrii, przy uwzględnieniu i dostosowaniu się do możliwości pacjenta, jest włączenie go w nurt aktywności społecznej ${ }^{30}$. Dodatkowo model psychiatrii środowiskowej zakłada podmiotowość człowieka, dlatego w toku dehospitalizacji konieczne jest zdiagnozowanie zapotrzebowania na konkretny, spersonalizowany rodzaj wsparcia społecznego z uwzględnieniem zachowanych zasobów osoby chorującej oraz potrzeb i możliwości jej otoczenia. Jednocześnie potrzebne jest odpowiednie prowadzenie chorującego tak, aby trafiał do odpowiednich, współpracujących instytucji, gdzie będzie otrzymywał jak najtrafniejszą pomoc, z uwzględnieniem nie dublowania działań ${ }^{31}$.

\section{Pedagogika specjalna jako przestrzeń i źródło działań terapii środowiskowej}

Przedstawione wyżej współczesne podejście - interdyscyplinarne, aktywizujące, uspołecznione (środowiskowe), zwiększające zainteresowanie i postrzeganie wychodzące poza macierzystą dziedzinę nauki ${ }^{32}$, jest obecne w pedagogice specjalnej. Jej teoretycy zauważają, że jest to nauka łączona i złączona z biologią, medycyną, filozofią, psychologią, antropologią ${ }^{33}$ oraz socjologią ${ }^{34}$, zaś jakość życia osób z niepełnospraw-

${ }^{28}$ K.T. Mueser, S. Gingerich, dz. cyt.

${ }^{29}$ S. Leszto, A. Witusik, T. Pietras, Terapia pedagogiczna dorostych $w$ psychiatrii $i$ w medycynie somatycznej. Ujęcie psychologiczne, biomedyczne i aksjologiczne, Naukowe Wydawnictwo Piotrkowskie, Piotrków Trybunalski 2013.

${ }^{30}$ G. Thornicroft, M. Tansella, W stronę lepszej psychiatrycznej opieki zdrowotnej, Instytut Psychiatrii i Neurologii, Warszawa 2010.

${ }_{31}$ M. Załuska, Funkcjonowanie społeczne i zapotrzebowanie na opiekę środowiskowa w schizofrenii, Instytut Psychiatrii i Neurologii, Warszawa 2000.

${ }^{32}$ A. Zamkowska, Interdyscyplinarność i multidyscyplinarność $w$ teorii i praktyce pedagogiki specjalnej, [w:] A. Pawlak, D. Chimicz, Z. Palak (red.), Wielość obszarów we wspótczesnej pedagogice specjalnej, Wydawnictwo Naukowe Uniwersytetu Marii Curie-Skłodowskiej, Lublin 2012.

${ }_{33}$ W. Dykcik, Pedagogika specjalna wobec aktualnych sytuacji i problemów osób niepełnosprawnych, Wydawnictwo Naukowe PTP, Poznań 2005.

${ }^{34}$ W. Dykcik, Wprowadzenie w przedmiot pedagogiki specjalnej jako nauki, [w:] W. Dykcik, (red.), Pedagogika specjalna, Wydawnictwo Naukowe Uniwersytetu Adama Mickiewicza, Poznań 1998. 
nościami, w każdym z jego wymiarów - biologicznym, społecznym i osobowościowym - jest ściśle powiązana z wiedzą, umiejętnościami oraz współpracą specjalistów z wielu dziedzin ${ }^{35}$. Dlatego też, jak zauważa Deborah Deutsch Smith, „odpowiedź na pytanie, czym zajmuje się pedagogika specjalna, czyli jaki jest obszar zainteresowań tej dyscypliny, wcale nie jest oczywista. Co więcej, ulega ona zmianom, które są uwarunkowane ogólnymi przemianami społeczno-kulturowymi, następującymi w różnych obszarach życia społecznego, a przede wszystkim przemianami w stanie wiedzy, polegającymi na postępie w zakresie diagnostyki chorób i zaburzeń oraz poznania ich mechanizmów, a wreszcie zmianami tożsamości samej pedagogiki specjalnej”36.

Wspomniane społeczno-kulturowe przemiany mają wielowiekową tradycję. Podejście do osób z niepełnosprawnością przechodziło wiele przeobrażeń: od dzieciobójstwa do uznania równi praw, od wrogości do akceptacji, od koncentracji na wadach po poszukiwanie mocnych stron, od izolacji do integracji ${ }^{37}$, od paternalistycznego traktowania osób, wobec których podejmowane są działania terapeutyczne - po uznanie ich za partnerów, którzy mogą współdecydować o sobie i swoim życiu ${ }^{38}$. Na kanwie tych przemian naukowcy oraz praktycy opracowywali coraz lepsze metody pomocy i współpracy. Ich efektem było stworzenie subdyscypliny pedagogicznej pedagogiki specjalnej, który była i jest odpowiedzialna za rozwój teorii, jak również praktyki, związanej z pomocą osobom z niepełnosprawnościami. W Polsce początki naukowej pedagogiki specjalnej przypadają na początek XX wieku ${ }^{39}$.

Mimo występującego w społeczeństwie potocznego przekonania, że pedagogika, a w tym pedagogika specjalna, dotyczą przede wszystkim oddziaływań wobec dzieci, naukowcy podkreślają, że miejsce pedagoga specjalnego jest również tam, gdzie pomocy potrzebują dorośli ${ }^{40}$. Dlatego też poza definicjami, w których nieokreślony jest wiek: „nauka o nauczaniu i wychowywaniu jednostek niepełnosprawnych, odbiegających od normy psychicznej lub fizycznej ${ }^{41}$, dostępne są takie, które podkreślają również konieczność pomocy osobom w wieku adolescencyjnym: pedagogika specjalna jest tą gałęzią pedagogiki ogólnej, która obejmuje swą działalnością rewalidacyjną jednostki odchylone od normy (dzieci, młodzież, dorosłych), których upośledzenie, choroba

${ }^{35}$ J. Konarska, Interdyscyplinarność jako konieczność i wyzwanie w pedagogice specjalnej, [w:] A. Pawlak, D. Chimicz, Z. Palak (red.), dz. cyt.

${ }^{36}$ D. Deutsch Smith, Pedagogika specjalna. Podręcznik akademicki, t. 2, Wydawnictwo Naukowe PWN, Warszawa 2008, s. 322.

${ }^{37}$ W. Dykcik, Wprowadzenie..., dz. cyt.

38 A. Twardowski, Kierunki zmian we współczesnej polskiej pedagogice specjalnej, [w:] T. Żółkowska (red.), Pedagogika specjalna - koncepcje i rzeczywistość. Konteksty pedagogiki specjalnej, t. II, Print Group, Szczecin 2001.

${ }^{39}$ Z. Sękowska, Wprowadzenie do pedagogiki specjalnej, Wydawnictwo APS, Warszawa 2001.

${ }^{40}$ Cz. Kosakowski, Kształcenie pedagogów specjalnych na tle przemian, [w:] M. Chodkowska (red.), Człowiek niepełnosprawny. Charisteria dla Profesor Zofii Sękowskiej, Wydawnictwo Naukowe Uniwersytetu Marii Curie-Skłodowskiej, Lublin 1994.

${ }^{41}$ J. Sowa, Pedagogika specjalna w zarysie, Wydawnictwo Oświatowe FOSZE, Rzeszów 1997, s. 17. 
lub nieprzystosowanie społeczne w sposób wyraźny wpływa na procesy kształtujące ich osobowość oraz stosunki międzypersonalne [...]"42. Uzupełnieniem powyższej definicji jest to, co zauważył Władysław Dykcik: odchylenia dotyczą nie tylko osób będących poniżej, ale również powyżej normy ${ }^{43}$, co warto podkreślić, choć samo pojęcie odchyleń (odchyłów), schodzi we współczesnym, humanistycznym paradygmacie pedagogiki specjalnej na plan dalszy, a nawet jest usuwane z jej dyskursu ${ }^{44}$. Zastępuje je całościowe i holistyczne podejście, oparte na identyfikacji i ograniczaniu barier oraz na zasobach wykorzystywanych do optymalizacji funkcjonowania i podnoszenia jakości życia osób, w tym poprzez ich edukację. W przypadku schizofrenii, oprócz pedagogiki specjalnej, działania te - ze względu na wiek osób chorujących - wpisują się także w obszar andragogiki oraz gerontologii. Ich celem jest bowiem między innymi zmiana kształcenia formalnego, w niezależne i nieformalne sytuowanie edukacji w centrum aktywności człowieka dorosłego ${ }^{45}$. To cel istotny w cywilizacji zmierzającej ku modelowi, w którym wartościami stają się informacje, wiedza i kompetencje, a realizacją tego modelu jest edukacja przez całe życie ${ }^{46}$. Potencjał edukacji ustawicznej nabiera szczególnego znaczenia w przypadku przewartościowań, koniecznych by skutecznie zmagać się z trudnościami wynikającymi z choroby (w tym psychicznej) czy niepełnosprawności. Zatem dorobek andragogiki oraz gerontologii może i powinien być wykorzystany w obszarze pedagogiki specjalnej, otwierającej się na osoby chorujące na schizofrenię.

Pedagogika specjalna nie jest jednolitą nauką. Obecny jest w niej podział na subdyscypliny, które przez lata ulegały przemianom. Zmieniał się ich zakres oraz nazewnictwo. Przykładem może być zmiana z nazwy podkreślającej działanie: rehabilitacja dzieci niewidomych i słabo widzących, rehabilitacja dzieci niesłyszących i słabo słyszących, na ogólną nazwę: tyflopedagogika, surdopedagogika ${ }^{47}$. W klasycznym dla współczesnej pedagogiki specjalnej podręczniku Zofii Sękowskiej przedstawione są następujące subdyscypliny:

- oligofrenopedagogika,

- logopedia,

${ }^{42}$ J. Doroszewska, Pedagogika specjalna. Tom 1. Podstawowe problemy teorii i praktyki, Zakład Narodowy im. Ossolińskich, Wrocław 1989, s. 51.

${ }^{43}$ W. Dykcik W., Wprowadzenie..., dz. cyt.

${ }^{44}$ A. Krause, Wspótczesne paradygmaty pedagogiki specjalnej, Oficyna Wydawnicza Impuls, Kraków 2010.

${ }^{45}$ J. Półturzycki, Pedagogika dorosłych, [w:] A. Fabiś (red.), Wyzwania współczesnej edukacji dorosłych. Unowocześnianie procesu kształcenia dorosłych, Górnośląska Wyższa Szkoła Pedagogiczna, Mysłowice 2005.

${ }^{46}$ A. Chabior A., Kształcenie ustawiczne jako priorytet w nowym modelu edukacji, [w:] A. Fabiś (red.), dz. cyt.

${ }^{47}$ Ciekawe, że współczesny, demedykalizujący trend, sprzyja obecnie także tendencjom odwrotnym, a więc odwrotu od obcobrzmiących, nacechowanych medycznie nazw, do nazw opisowych, nieetykietyzujących. 
- pedagogika korekcyjna,

- pedagogika resocjalizacyjna,

- pedagogika terapeutyczna,

- praca socjalna,

- surdopedagogika,

- tyflopedagogika ${ }^{48}$.

Ze względu na to, że pedagogika terapeutyczna jedynie częściowo zajmuje się zaburzeniami psychicznymi ${ }^{49}$ - jest tam dla nich miejsce - niczym w tablicy Mendelejewa dla nowych pierwiastków chemicznych - ale miejsca tego nie wypełnił jeszcze użyteczny teoretycznie i praktycznie zakres wiedzy naukowej. Pojawiają się zatem jeszcze inne propozycje, poszerzające wymienione wyżej subdyscypliny o bardziej szczegółowe działy, zawierające przestrzeń dla niepełnosprawności niezauważanych w poprzednim podziale (dotyczy to nie tylko zaburzeń psychicznych). Na przykład Andrzej Witusik i wsp. proponują oprócz wskazanych wyżej (lub ich połączenia, jak surdotyflopedagogika lub pedagogika osób ze sprzężonymi upośledzeniami), jeszcze następujące subdyscypliny:

- pedagogika osób z niepełnosprawnością ruchową,

- pedagogika osób z trudnościami w uczeniu się,

- pedagogika dzieci zdolnych i uzdolnionych,

- pedagogika terapeutyczna chorych somatycznie,

- pedagogika terapeutyczna osób z autyzmem,

- tanatopedagogika,

- pedagogika osób chorych na zaburzenia psychotyczne/psychiczne ${ }^{50}$.

Wielość działów pedagogiki specjalnej jest pochodną wielości podmiotów, objętych refleksją teoretyczną, jak również praktycznymi działaniami. Są to osoby:

- z trudnościami w poznawaniu świata i komunikowania się z nim w wyniku braku lub uszkodzenia jednego lub kilku analizatorów zmysłowych;

- mające ograniczoną zdolność do działania, aktywnego udziału w życiu społecznym w efekcie uszkodzenia narządów ruchu lub przewlekłej choroby,

- wymagające działań resocjalizacyjnych wskutek zaniedbań lub błędów rodziców/opiekunów lub szkoły;

- których procesy poznawcze przebiegają w sposób zaburzony, zmieniony, a ich obraz świata jest nieadekwatny;

- przekraczają poziom normy inteligencji - poniżej lub powyżej normy ${ }^{51}$.

${ }^{48}$ Z. Sękowska, Wprowadzenie do pedagogiki specjalnej, Akademia Pedagogiki Specjalnej im. Marii Grzegorzewskiej, Warszawa 2001.

49 A. Witusik i in., dz. cyt.

50 Tamże.

${ }^{51}$ Z. Sękowska, za: I. Chrzanowska, Pedagogika specjalna. Od tradycji do wspótczesności, Oficyna Wydawnicza Impuls, Kraków 2015. 
Jednakże, jak podkreśla Janina Doroszewska, mogą tu znaleźć się również osoby, których odchylenie od normy jest czasowe. Jeśli ich niepełnosprawność jest efektem niezbyt trwałych uszkodzeń ciała lub posiadają odpowiednie predyspozycje psychiczne i osobowościowe, mają szansę na szybki powrót do tak zwanego środowiska "normalnego" ${ }^{2}$ - obecnie powiedzielibyśmy, iż mają szansę na ponowne włączenie do głównego nurtu życia zarówno wąsko, jak i szeroko rozumianego środowiska społecznego.

Wobec wymienionych powyżej osób, pedagodzy specjalni podejmują różnorodne działania wspierające i pomocowe, które są związane z:

- wyrównywaniem szans, zachowaniem podmiotowości: podczas terapii, jak również w życiu codziennym, możliwością samodecydowania o sposobie terapii oraz o życiu;

- wspieraniem integracji społecznej oraz asymilacji: związanymi z przygotowaniem osób z niepełnosprawnościami do życia w społeczeństwie osób pełnosprawnych oraz kreowaniem postaw akceptacji ze strony tegoż społeczeństwa;

- przeciwdziałaniem oraz eliminacją dyskryminacji i marginalizacji: powiązanymi z przekonaniami, stereotypami;

- humanizacją życia: godnym traktowaniem, pełnoprawnością;

- indywidualizacją: przede wszystkim związana z procesem pomocowym i terapeutycznym;

- nabywaniem umiejętności, które umożliwiają samodzielne lub jak najbardziej samodzielne funkcjonowanie ${ }^{53}$.

Oddziaływania terapeutyczne wobec dorosłych czy osób starszych są przedmiotem andragogiki specjalnej oraz gerontologii specjalnej, a metody, jakie wykorzystuje, są metodami typowymi dla pedagogiki. Jednakże procesy, jakie zachodzą w procesie nauczania i wychowania, są podobne do tych obecnych w psychoterapii (np. nawiązanie kontaktu, przeniesienie, przeciwprzeniesienie, opór wobec terapii), a ich skuteczność zależy od umiejętności i kompetencji, nawiązania relacji, pozytywnego nastawienia, ćwiczenia nowych zachowań prowadzących do lepszego, sprawniejszego życia ${ }^{54}$.

Wizja w miarę samodzielnego, w miarę niezależnego życia (independent life) ${ }^{55}$ jest jedną z najważniejszych współczesnych idei w pedagogice specjalnej, a jednocześnie najważniejszym celem ukierunkowującym terapię środowiskową osób ze schizofrenią i innymi zaburzeniami psychicznymi. Terapia środowiskowa jako współczesny, postulowany trend opieki psychiatrycznej, jest nie tylko zgodna w celach z pedagogiką specjalną, ale wymaga także partnerów.

\footnotetext{
52 J. Doroszewska, dz. cyt.

53 I. Chrzanowska, dz. cyt.

54 S. Leszto i in., dz. cyt.

${ }^{55}$ D. Podgórska-Jachnik, dz. cyt.
} 


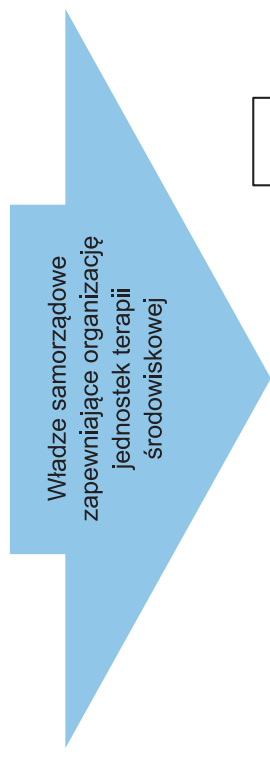

\section{Powszechność i dostępność terapii}
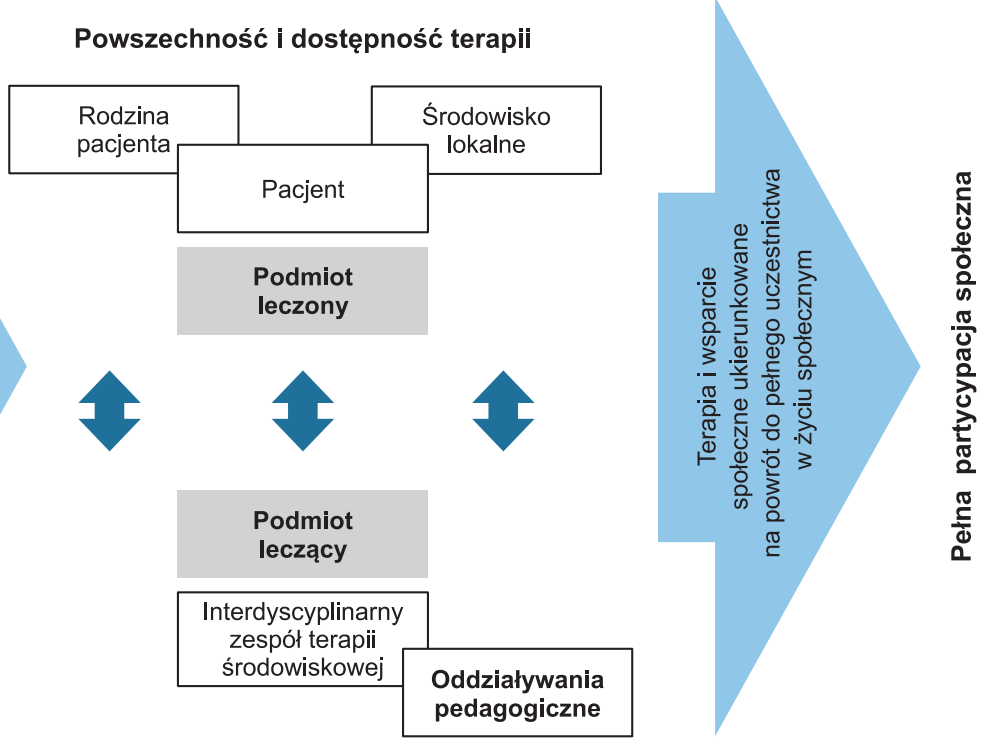

Zapobieganie stygmatyzacji

Rysunek 1. Model terapii środowiskowej osób ze schizofrenią z przestrzenią dla pedagogiki Źródło: modyfikacja własna modelu D. Podgórskiej-Jachnik ${ }^{56}$ - za zgodą autorki.

Na wykresie widać wyraźnie usytuowanie pedagogiki w działaniach wspierających osoby ze schizofrenią w ramach współpracy interdyscyplinarnego zespołu terapii środowiskowej, ale i poza nim. Istotny jest kierunek działań: terapia i wsparcie społeczne ukierunkowane na powrót do pełnego uczestnictwa w życiu społecznym.

\section{Schizofrenia a pedagogika specjalna - pedagogika specjalna a schizofrenia}

Wielu autorów uważa, że jednymi z ważniejszych zadań pedagogiki specjalnej są: pomoc w normalizacji sytuacji życiowej, włączanie osób z niepełnosprawnościami w nurt życia społecznego ${ }^{57}$, jak również nabywanie przez nich kompetencji w codziennym $\dot{z} y c i u^{58}$. Są one zaś powiązane $z$ wypełnianiem ról społecznych, a zdolność do nich jest wyznacznikiem tego, kogo można uznać za osobę z niepełnosprawnością. Zauważyła to Lidia Sikoń, powołując się na Ustawę o rehabilitacji zawodowej i społecznej oraz zatrudnianiu osób niepełnosprawnych ${ }^{59}$. Tak rozumiana niepełnosprawność pozwala na uznanie, że osoby chorujące na schizofrenię również należą do tej

\footnotetext{
56 D. Podgórska-Jachnik, T. Pietras, dz. cyt., s. 71.

57 A. Witusik i in., dz. cyt.

58 I. Chrzanowska, dz. cyt.

59 L. Sikoń, Osoba niepełnosprawna - jej status, [w:] T. Żółkowska (red.), dz. cyt.
} 
grupy. Już w samej definicji zawarte jest pogorszenie funkcjonowania osoby chorują$\mathrm{cej}^{60}$, zaś efektywność terapii i działań pomocowych oraz wspierających wzrasta, gdy poprawiona jest jakość kontaktów społecznych ${ }^{61}$. Odnosi się to również do grup, jakimi zajmuje się pedagogika specjalna - osoby, które dotyka przewlekła choroba, jak również takich, których obraz świata jest odmieniony ${ }^{62}$. Chorujący na schizofrenię należą do obu.

Dotąd schizofrenią zajmowała się przede wszystkim medycyna (psychiatria) oraz psychologia kliniczna. Jednakże pedagogika specjalna od dawna jest związana $z$ tymi dyscyplinami ${ }^{63}$, nie tylko czerpiąc inspiracje, ale współpracując w procesie leczenia, rehabilitacji. Dlatego też współpraca związana z terapią osób chorujących na schizofrenię może być kolejnym krokiem na drodze przemian tej subdyscypliny nauki ${ }^{64}$. Wspomniane zmiany nie naruszają charakteru pedagogiki specjalnej, ponieważ oddziaływania, jakie mogą być wykorzystywane przez pedagogów specjalnych do pracy z osobami chorującymi na schizofrenię, są wykorzystywane przez nich na co dzień w przypadku innych niepełnosprawności. Są to między innymi metody takie, jak: trening umiejętności społecznych, psychoedukacja, terapia zajęciowa/kreatywna - arteterapia ${ }^{65}$.

Postulat zajmowania się osobami z zaburzeniami psychicznymi, w tym schizofrenią, pojawił się już wcześniej. Między innymi wspominał o tym Jan Pańczyk, kiedy określił, jacy specjaliści z zakresu pedagogiki specjalnej są potrzebni na rynku pracy. Wśród oligofrenopedagogów, pedagogów resocjalizacyjnych, tyflopedagogów, surdopedagogów, pedagogów zajmujących się sprzężonymi niepełnosprawnościami, pracującymi z osobami z niepełnosprawnością ruchową, z autyzmem, z chorobami przewlekłymi, wymienił również pedagogów wspierających osoby z zaburzeniami psychicznymi $^{66}$. Jak zauważyli Andrzej Witusik i wsp., pedagodzy specjalni już teraz - niekiedy pośrednio i incydentalnie - zajmują się osobami chorującymi na schizofrenię, np. organizując terapię zajęciową. Podkreślili również, że nieobecność w teorii pedagogiki specjalnej, jak również w programie studiów, zagadnień dotyczących tej choroby, skutkuje brakiem wiedzy, którą pedagodzy muszą zdobywać od podstaw, stykając się ze schizofrenią w praktyce. Oznacza to słabsze przygotowanie do efektywnej terapii, niekorzystne warunki rozwoju interdyscyplinarnej terapii środowiskowej oraz możliwość niesienia profesjonalnej pomocy na miarę wyobrażeń o współczesnych celach wspierania osób ze schizofrenią. Wydaje się więc, że to ważne - wręcz niezbędne - dopełnienie dotychczasowego obszaru zainteresowań pedagogiki specjalnej.

${ }^{60}$ Ch. Frith, E. Johnstone, dz. cyt.

${ }^{61}$ M. Brichwood, Ch. Jackson, dz. cyt.

62 Z. Sękowska, dz. cyt., za: I. Chrzanowska, dz. cyt.

${ }^{63}$ W. Dykcik, Wprowadzenie, dz. cyt.

${ }^{64}$ D. Deutsch Smith, dz. cyt.

${ }^{65}$ S. Leszto i in., dz. cyt.

${ }^{66}$ J. Pańczyk, Kształcenie pedagogów specjalnych w Polsce, [w:] K.J. Zabłocki, D. Gorajewska (red.), Pedagogika specjalna - kontynuacja tradycji dla przyszłości, Akademia Pedagogiki Specjalnej, Warszawa 2004. 
Dodatkową korzyścią z włączenia w teorię pedagogiki specjalnej problematyki profesjonalnego wsparcia psychospołecznego - w tym pedagogicznego - osób chorych na schizofrenię oraz zdrowiejących, może być nie tylko lepsze przygotowanie merytoryczne absolwentów oraz stworzenie efektywniejszych, interdyscyplinarnych sposobów pomocy, ale w dalszej perspektywie - stworzenie nowych miejsc pracy. Pomoc pedagoga specjalnego jest bowiem już potrzebna i będzie potrzebna nadal na oddziałach szpitalnych, w tym psychiatrycznych, poradniach zdrowia psychicznego, zespołach leczenia, domach pomocy społecznej i środowiskowych domach samopomocy, jak również hostelach oraz mieszkaniach chronionych, zespołach interwencji kryzysowej, na turnusach rehabilitacyjnych i na warsztatach terapii zajęciowej ${ }^{67}$. Większa wiedza o specyfice uwarunkowań rehabilitacji tych osób - to lepsze wsparcie, tym samym większa szansa na podniesienie jakości ich życia.

Ostatnią kwestią jest kierunek rozwoju pedagogiki specjalnej. Może on oznaczać: stworzenie nowej subdyscypliny - np. jak sugerują wspomniani wyżej autorzy pedagogiki osób chorych na zaburzenia psychotyczne/psychiczne ${ }^{68}-$ lub też poszerzenie dotychczasowego zakresu pedagogiki terapeutycznej o treści dotyczące schizofrenii, pogłębienie tej problematyki, obecnej tam dotychczas w śladowych ilościach. Oba rozwiązania są możliwe, choć drugie bliższe jest idei ruchu włączającego, tworzącego przestrzeń dla wszystkich różnic i odmienności. Sama formalna strona wyodrębniania - lub też nie - nowej subdyscypliny, nie jest jednak tak istotna, jak samo poważne zajęcie się tą problematyką ${ }^{69}$. Wobec stałego wzrostu zagrożeń chorobami psychicznymi we współczesnym świecie, wydaje się to wyzwaniem obecnych czasów.

\section{Podsumowanie}

Podsumowując niniejszy artykuł, należy powiedzieć, że charakter choroby, jaką jest schizofrenia, zaburzenia, z jakimi spotykają się osoby chorujące, oraz to, jakiej pomocy oraz wsparcia poza interwencją medyczną potrzebują, powoduje ryzyko niepełnosprawności. Łącząc tę kwestię z wymaganiami wynikających z praktyki - niedostatecznym merytorycznym przygotowaniem pedagogów specjalnych do wspierania osób chorych na schizofrenię oraz koniecznością współpracy terapeutów wielu dziedzin w procesie terapii środowiskowej, a właściwie dopiero wypracowania jej modelu - wydaje się, że w przemianach, jakie są udziałem pedagogiki (w szczególności specjalnej) powinno znaleźć się miejsce dla problematyki schizofrenii. Można przypuszczać, że jest to szansa na znalezienie drogi do bardziej efektywnej terapii oraz skutecznego wspierania procesu zdrowienia i inkluzji społecznej osób chorujących psychicznie.

\footnotetext{
${ }^{67}$ A. Witusik i in., dz. cyt.

68 Tamże.

${ }^{69}$ Tamże.
} 


\section{Bibliografia}

Beck A.T., Rector N.A., Stolar N., Grant P., Schizofrenia w ujęciu poznawczym. Teoria, badania i terapia, Wydawnictwo Uniwersytetu Jagiellońskiego, Kraków 2010.

Birchwood M., Jackson Ch., Schizofrenia. Modele kliniczne i techniki terapeutyczne, Gdańskie Wydawnictwo Psychologiczne, Gdańsk 2006.

Carson R.C., Butcher J.N., Mineka S., Psychologia zaburzeń, t. 2, Gdańskie Wydawnictwo Psychologiczne, Gdańsk 2003.

Chabior A., Kształcenie ustawiczne jako priorytet w nowym modelu edukacji, [w:] A. Fabiś (red.), Wyzwania współczesnej edukacji dorosłych. Unowocześnianie procesu kształcenia dorosłych, Górnośląska Wyższa Szkoła Pedagogiczna, Mysłowice 2005.

Chrzanowska I., Pedagogika specjalna. Od tradycji do współczesności, Oficyna Wydawnicza Impuls, Kraków 2015.

Colman A.M., Słownik psychologii, Wydawnictwo Naukowe PWN, Warszawa 2009.

Deutsch Smith D., Pedagogika specjalna. Podręcznik akademicki, t. 2, Wydawnictwo Naukowe PWN, Warszawa 2008.

Doroszewska J., Pedagogika specjalna. Tom 1. Podstawowe problemy teorii i praktyki, Zakład Narodowy im. Ossolińskich, Wrocław 1989.

Dykcik W., Pedagogika specjalna wobec aktualnych sytuacji i problemów osób niepełnosprawnych, Wydawnictwo Naukowe PTP, Poznań 2005.

Dykcik W., Wprowadzenie w przedmiot pedagogiki specjalnej jako nauki, [w:] W. Dykcik, (red.), Pedagogika specjalna, Wydawnictwo Naukowe Uniwersytetu Adama Mickiewicza, Poznań 1998.

Epidemiologia zaburzeń psychiatrycznych i dostępność psychiatrycznej opieki zdrowotnej EZOP - Polska, http://www.ezop.edu.pl (dostęp: 8.05.2018).

Frith Ch., Johnstone E., Schizofrenia, Gdańskie Wydawnictwo Psychologiczne, Gdańsk 2012.

Kępiński A., Schizofrenia, Wydawnictwo Literackie, Kraków 2011.

Konarska J., Interdyscyplinarność jako konieczność i wyzwanie w pedagogice specjalnej, [w:] A. Pawlak, D. Chimicz, Z. Palak (red.), Wielość obszarów we współczesnej pedagogice specjalnej, Wydawnictwo Naukowe Uniwersytetu Marii Curie-Skłodowskiej, Lublin 2012.

Kosakowski Cz., Kształcenie pedagogów specjalnych na tle przemian, [w:] M. Chodkowska (red.), Człowiek niepełnosprawny. Charisteria dla Profesor Zofii Sękowskiej, Wydawnictwo Naukowe Uniwersytetu Marii Curie-Skłodowskiej, Lublin 1994.

Krause A., Współczesne paradygmaty pedagogiki specjalnej, Oficyna Wydawnicza Impuls, Kraków 2010.

Leszto S., Witusik A., Pietras T., Terapia pedagogiczna dorosłych $w$ psychiatrii $i$ w medycynie somatycznej. Ujęcie psychologiczne, biomedyczne i aksjologiczne, Naukowe Wydawnictwo Piotrkowskie, Piotrków Trybunalski 2013. 
Mueser K.T., Gingerich S., Życie ze schizofrenia. Poradnik dla rodzin, Dom Wydawniczy REBIS, Poznań 2008.

Pańczyk J., Kształcenie pedagogów specjalnych w Polsce, [w:] K.J. Zabłocki, D. Gorajewska (red.), Pedagogika specjalna - kontynuacja tradycji dla przyszłości, Akademia Pedagogiki Specjalnej, Warszawa 2004.

Podgórska-Jachnik D., Pietras T., Praca socjalna z osobami z zaburzeniami psychicznymi i ich rodzinami, Centrum Rozwoju Zasobów Ludzkich, Warszawa 2014. Półturzycki J., Pedagogika dorosłych, [w:] A. Fabiś (red.), Wyzwania współczesnej edukacji dorosłych. Unowocześnianie procesu kształcenia dorosłych, Górnośląska Wyższa Szkoła Pedagogiczna, Mysłowice 2005.

Pużyński S., Wciórka J., Klasyfikacja zaburzeń psychicznych i zaburzeń zachowania w ICD-10, Uniwersyteckie Wydawnictwo Medyczne VESALIUS, Kraków 2000.

Saks E.R., Schizofrenia. Moja droga przez szaleństwo, Burda Publishing Polska, Warszawa 2014.

Sękowska Z., Wprowadzenie do pedagogiki specjalnej, Akademia Pedagogiki Specjalnej im. Marii Grzegorzewskiej, Warszawa 2001.

Sękowska Z., Wprowadzenie do pedagogiki specjalnej, Wydawnictwo WSPS, Warszawa 1998.

Sikoń L., Osoba niepełnosprawna - jej status, [w:] T. Żółkowska (red.), Pedagogika specjalna - koncepcje i rzeczywistość. Konteksty pedagogiki specjalne, t. II, Print Group, Szczecin 2001.

Sowa J., Pedagogika specjalna w zarysie, Wydawnictwo Oświatowe FOSZE, Rzeszów 1997.

Strauss J., Carpenter W., Bartko J., The diagnosis an understanding of schizophrenia. Part III, „Schizophrenia Bulletin”, no. 11/1974, Winter.

Thornicroft G., Tansella M., W stronę lepszej psychiatrycznej opieki zdrowotnej, Instytut Psychiatrii i Neurologii, Warszawa 2010.

Twardowski A., Kierunki zmian we współczesnej polskiej pedagogice specjalnej, [w:] T. Żółkowska (red.), Pedagogika specjalna - koncepcje i rzeczywistość. Konteksty pedagogiki specjalnej, t. II, Print Group, Szczecin 2001.

Warner R., Recovery from schizophrenia: psychiatry and political economy, Routledge, London 1994.

Wciórka J., Psychozy schizofreniczne, [w:] S. Pużyński, J. Rybakowski, J. Wciórka, Psychiatria. Psychiatria kliniczna, t. 2, Elsevier Urban \& Partner, Wrocław 2011.

Witusik A., Leszto S., Podgórska-Jachnik D., Pietras T., Schizofrenia w kontekście nauk społecznych. Osoba chora na schizofrenię w obszarze zainteresowań pedagogiki specjalnej, Wydawnictwo Continuo, Wrocław 2015.

Zalewski G., Kontrowersje wokół schizofrenii. Świadomość zdrowych i chorych, Trans Humana, Białystok 2001.

Załuska M., Funkcjonowanie społeczne i zapotrzebowanie na opiekę środowiskowa w schizofrenii, Instytut Psychiatrii i Neurologii, Warszawa 2000. 
Zamkowska A., Interdyscyplinarność i multidyscyplinarność w teorii i praktyce pedagogiki specjalnej, [w:] A. Pawlak, D. Chimicz, Z. Palak (red.), Wielość obszarów we wspótczesnej pedagogice specjalnej, Wydawnictwo Naukowe Uniwersytetu Marii Curie-Skłodowskiej, Lublin 2012.

\section{Pedagogy in the face of schizophrenia}

Abstract: This article contributes to debates on changes in special pedagogy. Its purpose is to show the need for the further inclusion of schizophrenia within this academic discipline. First, the author provides a historical, diagnostic and symptomatic outline of schizophrenia, and describes its psycho-social effects. Second, the author offers a justification for the interdisciplinary support of the therapeutic process and outlines the assumptions of the psychiatric community. In the following subsection the author discusses the theoretical assumptions of special pedagogy - historical outline, goals, sub-discipline, subjects, subject and nature of undertaken activities. In the final subsection, it is shown that schizophrenia can be interpreted as a disability and that including it into the mainstream of special pedagogy won't change nature of the discipline.The author discusses possible ways in which special pedagogy can develop - by creating a new subdiscipline or by extending therapeutic pedagogy.

Keywords: special pedagogy, community psychiatry, schizophrenia, disability, therapeutic pedagogy, inclusion, support

\footnotetext{
About the author: Monika Banaszczyk - a graduate of the University of Lodz, psychologist, PhD student of pedagogy at the Kazimierz Wielki University in Bydgoszcz. Her publications concern to special pedagogy, schizophrenia, disability, personality and stigmatization.
} 


\title{
Porozumiewanie się pracowników z podopiecznymi jako proces budowania i podtrzymywania relacji w rodzinnym domu dziecka
}

\begin{abstract}
Streszczenie: Artykuł w sposób opisowy przedstawia problematykę porozumiewania się pracowników z podopiecznymi jako proces budowania i podtrzymywania relacji w rodzinnym domu dziecka. Autorka artykułu przedstawia najpierw sens i znaczenie porozumiewania się w rodzinnym domu dziecka, a następnie prezentuje wyniki wywiadu narracyjnego. Ciekawa jest również perspektywa małżeństwa, które przez blisko dwanaście lat opiekowało się kilkorgiem dzieci odebranym rodzicom na mocy decyzji sądu. Tekst ukazuje, jak wygląda porozumiewanie się pracowników z podopiecznymi rodzinnych domów dziecka, jakie problemy napotykali i czy udało im się sprostać temu wyzwaniu. Wynik badania biograficznego podzielony jest na kilka podtematów i obejmuje m.in. rodzaje i sposoby porozumiewania się pracowników z podopiecznymi oraz reguły komunikowania się w rodzinnym domu dziecka.
\end{abstract}

Słowa kluczowe: komunikacja, relacje społeczne, opieka zastępcza, rodzinny dom dziecka

\section{Wprowadzenie}

Rozpatrując kwestie budowania i podtrzymywania relacji w rodzinnym domu dziecka, nie można pominąć podstawowego procesu działania, jakim jest porozumiewanie się ${ }^{1}$ Stanowi ono ważny element wszystkich wzajemnych relacji zachodzących

\footnotetext{
Agnieszka Deja - mgr, doktorantka II roku studiów z zakresu pedagogika na Wydziale Nauk Społecznych Uniwersytetu Gdańskiego. Ukończone studia: pedagogika opiekuńczo-wychowawcza z terapią pedagogiczną, pedagogika społeczna. Zainteresowania: opieka zastępcza, rodzinne formy opieki zastępczej, rodzinne domy dziecka, interakcjonizm symboliczny.

${ }^{1}$ A. Tyszka, Rozmowa kultur, [w:] A. Kapciak, L. Korporowicz, A. Tyszka (red.), Komunikacja międzykulturowa - zbliżenia i impresje, Wydawnictwo Instytutu Kultury, Warszawa 1995, s. 11.
} 
pomiędzy członkami danej instytucji bądź organizacji. Komunikowanie się przybierać może zarówno postać mowy, jak i gestów czy zachowań. Język jest tym narzędziem, które w największym stopniu wykorzystuje się dla osiągnięcia porozumienia na płaszczyźnie wzajemnych stosunków interpersonalnych. Na poziomie komunikacji odbywa się koordynacja działań, które umożliwiają nie tylko wykonywanie czynności instrumentalnych, ale także tych dotyczących sfery psychicznej i emocjonalnej podopiecznego ${ }^{2}$.

\section{Założenia metodologiczne}

Komunikowanie się, to najbardziej fundamentalny proces społeczny, a jego celem jest uzgodnienie sposobu widzenia świata osób kontaktujących się wzajemnie w ramach danej zbiorowości. Dlatego właśnie przedmiotem badań uczyniono rodzinny system opieki zastępczej z perspektywy komunikacji pracowników z podopiecznymi rodzinnych domów dziecka. Na płaszczyźnie stosunków interpersonalnych analizie zostanie poddany proces porozumiewania się z punktu widzenia opiekunów Rodzinnego Domu Dziecka z Gdyni.

Celem artykułu jest analiza porozumiewania się w procesie budowania i podtrzymywania relacji pracowników z podopiecznymi rodzinnych domów dziecka. Zakres badań sprowadza się do problematyki porozumiewania się głównych aktorów w toku codziennych interakcji pracowników z podopiecznymi rodzinnych domów dziecka. Swoje wysiłki koncentruje na badaniu tych aspektów komunikacji, które bezpośrednio dotyczą pracownika i podopiecznego. Z tego względu główne pytanie badawcze brzmi następująco: „Jakie znaczenie ma porozumiewanie się w procesie budowania i podtrzymywania relacji pracowników z podopiecznymi w rodzinnym domu dziecka?".

Koncentrując się na opisie i analizie porozumiewania się między pracownikami a podopiecznymi rodzinnych domów dziecka, podejmowana jest próba zrozumienia danego „fragmentu” rzeczywistości oraz nakreślenia jego charakteru i specyfiki. Zamiarem autora, poza poznawczym znaczeniem prowadzonych badań, jest również położenie nacisku na rozpropagowanie idei wychowania rodzinnego, w wyniku której ludzie będą chętniej otwierać rodzinne domy dziecka i dadzą dzieciom możliwość na szczęśliwe i radosne dzieciństwo.

Rodzaj badań, jakie zastosowałam, to studium przypadku³, szczególną odmianą tych badań są badania biograficzne ${ }^{4}$. Metodą zbierania danych w tym podejściu jest

${ }^{2}$ K. Konecki, Praca w koncepcji socjologii interakcjonistycznej, „Studia Socjologiczne”, nr 1/1988, s. 235.

${ }^{3}$ D. Silverman, Prowadzenie badań jakościowych, Wydawnictwo Naukowe PWN, Warszawa 2008, s. 154.

4 T. Pilch, T. Bauman, Zasady badan pedagogicznych, Wydawnictwo Akademickie „Żak”, Warszawa 2010, s. 298-299. 
między innymi wywiad narracyjny ${ }^{5}$. Jak pisze Dariusz Kubinowski, badania narracyjne stawiają w „centrum szczególną osobę zaświadczającą całym swoim życiem oddanie, zaangażowanie, pasję nauczycielską, pedagogiczną; będzie to wtedy biografia pokazująca proces edukacji z perspektywy wychowującego - stosowanych przez niego metod, środków, instrumentów jego doświadczenia, poglądów, wartości, ideologii”6. Wywiad narracyjny z doświadczeniami pracowników spełnia powyższe kryteria, dlatego do realizacji badań posłużyłam się wywiadem narracyjnym - eksperckim, umożliwiającym poznanie zagadnień z zakresu życia wychowawczego i rodzinnego ${ }^{7}$. Osobami badanymi jest małżeństwo, będące w średnim wieku. Od 12 lat tworzą oni rodzinny dom dziecka i dzięki ich bogatemu doświadczeniu zawodowemu dowiedziałam się wielu interesujących faktów.

Jak pisze Tadeusz Pilch „badania biograficzne związane są ze szczególnymi jednostkami, których historia życia jest na tyle znacząca, że możemy dzięki niej dowiedzieć się czegoś ważnego o człowieku i o świecie, w jakim żyje bądź żył" jakościowe stosuje się między innymi wtedy, gdy badane zjawisko jest „drażliwe”, dotyczy problemów uznawanych przez badanych za intymne i prywatne. Przeważnie pracownicy rodzinnych domów dziecka są nieufni i niechętni do opowiadania o swoim życiu rodzinnym ludziom z zewnątrz. Osoby, z którymi udało mi się porozmawiać, to ludzie niezwykle pomocni i rozmowni.

Wskazówki Steinar Kvale były dla mnie dużą pomocą w konstruowaniu scenariusza wywiadu częściowo ustrukturyzowanego. Zgodnie z nurtem fenomenologicznym każdy człowiek nadaje indywidualne znaczenie otaczającej go rzeczywistości, co jest wyrazem subiektywnego pojmowania świata ${ }^{9}$. Dlatego też ważne było używanie w scenariuszu pytań pogłębiających, typu: opisz, wyjaśnij, w jakiej sytuacji itp. Ponadto swój scenariusz podzieliłam na trzy części tj. otwarcie, rozwinięcie i zakończenie. Każda z części określała, jakiego rodzaju pytania stosować ${ }^{10}$. Dzięki nim mogłam zrozumieć pojęcie komunikacji, jaką wartość ma komunikacja dla pracowników i kiedy ją stosują.

Materiał badawczy został zgromadzony podczas pobytu badacza w rodzinnym domu dziecka znajdujących się na terenie województwa pomorskiego. Rodzinny Dom Dziecka w Gdyni funkcjonuje od 2006 roku i jest prowadzony przez małżeństwo - żona 49 lat i mąż 54 lata. Małżeństwo posiada czwórkę swoich biologicznych

${ }^{5}$ D. Lalak, Podejście biograficzne w naukach o wychowaniu, [w:] S. Palka (red.), Podstawy metodologii badań w pedagogice, Wydawnictwo Akademickie „Żak”, Gdańsk 2010, s. 264.

${ }^{6}$ D. Kubinowski, Jakościowe badania pedagogiczne. Filozofia. Metodyka. Ewaluacja, Wydawnictwo Uniwersytetu Marii Curie-Skłodowskiej, Lublin 2010, s. 170.

${ }^{7}$ K. Kazimiersk, Wywiad narracyjny - technika i pojęcia analityczne, [w:] M. Czyżewski, A. Piotrowski, A. Rokuszewska-Pawełek (red.) Biografia a tożsamość narodowa, Katedra Socjologii Kultury Uniwersytetu Łódzkiego, Łódź 1997, s. 35.

8 Tamże, s. 329.

9 S. Kvale, Prowadzenie wywiadów, Wydawnictwo Naukowe PWN, Warszawa 2010, s. 108-109.

${ }^{10}$ D. Kubinowski, dz. cyt., s. 209-210. 
dzieci oraz opiekuje się ósemką dzieci powierzonych w wieku: 8 miesięcy, 3 lata, 4 lata, 11 lat, 16 lat, 17 lat i dwoje podopiecznych po 19 lat. Placówka mieści się w prywatnym domu z ogrodem i jest jednostką realizującą zadania opiekuńczo-wychowawcze, zgodnie $\mathrm{z}$ regulacjami zawartymi w stosownych aktach prawnych oraz określonych dokumentach wewnętrznych, takich jak statuty i regulaminy ${ }^{11}$.

Zaproszono mnie do salonu i poczęstowano kawą. Życzliwość i uśmiech małżonków sprawiły, że szybko poczułam się swobodnie. Wcielając się w rolę badacza, kierowałam się regułami prowadzenia badań naukowych szczególnie przy zadawaniu pytań. Zapewniłam wychowawców, że wywiad jest anonimowy i zostanie wykorzystany wyłącznie do celów naukowych. Badania przebiegały w przyjemnej i pozytywnej atmosferze.

\section{Sens i znaczenie komunikacji w rodzinnym domu dziecka - wyniki badań}

Każda instytucja ma określone i zarazem specyficzne sposoby komunikowania się. Wypracowanie określonych, wspólnych sposobów wymiany doświadczeń, wiedzy i przekazywanie własnych odczuć pomiędzy przedstawicielami danej organizacji sprawia zaś, że stajemy się członkiem danej zbiorowości. Zyskujemy poczucie przynależności do określonej grupy, środowiska, związku z współtowarzyszami i wytworzenia się więzi, także tej opartej na emocjach ${ }^{12}$. Egzemplifikacją powyższej analizy jest wybrany fragment wypowiedzi badanych:

Nasza dziewczynka, której się uczyliśmy przez trzy lata - ona ciągle chodziła z siatką, to było dziecko, które zawsze miało swoją reklamówkę ze swoimi rzeczami przy sobie, które ciągle uważało, że już stąd idzie. Bardzo długo nie chciała wchodzić w relacje, tylko był ciągle mur, ciągle ściana, ciągle krzyk, ciągle agresja. I ciągła taka gotowość do wyjścia. Dopiero kiedy poczuła się tutaj pewnie, kiedy poczuła się nagradzana, poczuła się dowartościowana, poczuła, że tutaj jest jej miejsce, kiedy ona rzeczywiście ma to, co jest jej, że to jest jej zwierzątko i to mogą być jej rzeczy, i to są tylko jej rzeczy, i nie musi mieć wszystkiego pod ręką. W końcu poczuła, że jest w domu” (żona).

Komunikacja służy integrowaniu się danej zbiorowości i tworzy podstawy wspólnotowości. Jest fundamentem w procesie socjalizacji jednostki, pozwala bowiem na przyjmowanie określonych wzorców oraz nabywanie charakterystycznych umiejęt-

${ }^{11}$ Rozporządzenie Rady Ministrów o pomocy społecznej z dnia 12.03.2004 r. (Dz.U. Nr 64, poz. 593); Rozporządzenie Ministra Pracy i Polityki Społecznej w sprawie placówek opiekuńczo-wychowawczych z dnia 14.02.2005 r. (Dz.U. Nr 37, poz. 331).

${ }_{12}$ D. Baraniewicz, M. Baraniewicz, Możliwości komunikacyjne uczniów z głębokim upośledzeniem umysłowym, [w:] J. Baran, A. Mikruta (red.), Umiejętności komunikacyjne osób z niepełnosprawnościa: teoria, diagnoza, wspomaganie, Wydawnictwo Naukowe Akademii Pedagogicznej, Kraków 2007, s. 195. 
ności interpersonalnych. Porozumiewanie się jest istotnym procesem społecznym, który tworzy podwaliny dla uzgadniania sposobu widzenia świata, kreowania podobnych abstrakcji w umysłach osób kontaktujących się wzajemnie w ramach danej zbiorowości ${ }^{13}$.

Porozumiewanie staje się szczególnie istotne, kiedy obiektem bezpośrednich działań jest dziecko przebywające w rodzinnym systemie opieki zastępczej. Wówczas znaczenie procesu komunikowania nie ogranicza się wyłącznie do aspektu współpracy pomiędzy członkami zbiorowości, będąc narzędziem - instrumentem w realizacji jej zadań, lecz zajmuje miejsce ważniejsze, pełniąc kluczową rolę w kreowaniu właściwej atmosfery w przestrzeni życiowej jednostek, stając się także jednym z istotnych czynników kształtowania się i podtrzymywania ich podmiotowości. Na pytanie: „W jaki sposób pracownicy budują więź emocjonalną z podopiecznymi?”, badani odpowiedzieli, że ogromne znaczenie ma spędzanie czasu z podopiecznymi, obdarzanie dzieci szacunkiem i akceptowanie ich takimi, jakie są.

Poświęcamy dzieciom dużo czasu, wspólnie spędzamy czas w domu czy na podwórku, później same przychodzą i pytają się, czy kawę zrobić, czy sobie usiądziemy i porozmawiamy, w takich drobnych rzeczach. Albo przychodzą i mówią o swoich problemach. Dużym sukcesem jest, jak dziecko potrafi przyjść i w końcu powiedzieć, o co chodzi. Jak potrafi usiąść, znaleźć chwilę, aby porozmawiać (żona).

Umiejętność porozumiewania się i rozumienia partnerów interakcji stanowi jeden z warunków wykonania pracy opiekuńczej, zarówno tej rozumianej instrumentalnie, jak też w podtrzymywaniu właściwych stanów emocjonalnych ${ }^{14}$. Zapewnianie odpowiedniej opieki staje się możliwe, a przede wszystkim efektywne w momencie, gdy dysponujemy wiedzą oraz doświadczeniem, umożliwiającymi zgodną z oczekiwaniami podopiecznych analizę i interpretację ich komunikatów werbalnych oraz niewerbalnych ${ }^{15}$. Na pytanie: „Jakie potrzeby posiadają podopieczni i w jaki sposób pracownicy je zaspokajają?”, badani respondenci odpowiedzieli:

Dzieci mają potrzebę miłości, stabilizacji i bezpieczeństwa. Nie udałoby się nam zaspokoić tych potrzeb, gdybyśmy z nimi nie rozmawiali. Na początku budujemy zaufanie, że się tu nie zawiodą - dopiero z tej pewności można budować uczucia wyższe - miłość czy przyjaźń [...]. Staramy się rozmawiać i pytać, czego chcą, czego oczekują, albo jakie mają pragnienia czy marzenia (mąż).

A zatem właściwa komunikacja odgrywa kluczową rolę w procesie zaspokajania potrzeb podopiecznych. Warto podkreślić, iż realizacja potrzeb wychowanków jest możliwa wyłącznie dzięki rozwinięciu określonego poziomu kompetencji komuni-

${ }^{13}$ Z. Nęcki, Komunikacja międzyludzka, Wydawnictwo Profesjonalnej Szkoły Biznesu, Kraków 1996, s. 36.

${ }^{14}$ K. Konecki, dz. cyt., s. 235.

15 Tamże, s. 235. 
kacyjnych pracowników oraz podopiecznych RDD. Przy czym to właśnie od opiekunów zależeć będzie w dużym stopniu, jak będą układały się relacje z podopiecznymi oraz podopiecznych między sobą ${ }^{16}$. W tym kontekście należy pamiętać, że specyfika komunikacji między podopiecznymi i opiekunami oznacza wysoki poziom strukturalnej złożoności, czego następstwem są pojawiające się trudności w relacjach interpersonalnych. Nierzadko rodzi to konieczność modyfikacji komunikacji oraz porozumienia się, budowanych na podstawie doświadczenia zdobywanego w zwykłych sytuacji dnia codziennego. Na pytanie: „W jaki sposób pracownicy rozwiązują sytuacje konfliktowe?", pracownicy odpowiadają:

Zazwyczaj pierwsza rzecz, to siadamy i słuchamy, co się dzieje, np. może ktoś używa słów, które nie są obraźliwe czy wulgarne, ale druga osoba czuje się dotknięta, więc mówimy, że niby to nie jest nic złego, ale tutaj to nam przeszkadza, każdy ma inną wrażliwość i czasami taka rozmowa po prostu wystarczy (mąż).

Mamy więc do czynienia ze zjawiskiem uczenia się rozumienia i poprawnej interpretacji emocji oraz symboliki znaków werbalnych i pozawerbalnych dokonywanej przez opiekunów. Warto podkreślić, że wypracowane schematy oczekiwanych działań i zachowań aktora interakcji często nie mają bezpośredniego zastosowania podczas kontaktu $\mathrm{z}$ wychowankiem. Wchodząc w interakcje $\mathrm{z}$ podopiecznym, opiekunowie często muszą poddać weryfikacji dotychczas żywione przekonania dotyczące intencji partnerów. Jeśli sytuacja, w jakiej się znajdujemy, jest w znaczącym stopniu innowacyjna i nie pozwala na zastosowanie dotychczasowej wiedzy, zmuszeni jesteśmy do wzmożonej pracy oraz do tego, aby świadomie na nowo uczyć się rozumieć i poprawnie interpretować zastaną rzeczywistość. Egzemplifikacją powyższej analizy jest wybrany fragment wypowiedzi pracownika:

Nigdy rotacja nie służy dobru dzieci, bo każda zmiana - wprowadza do domu pewne zaburzenie rytmu... ktoś odchodzi, ktoś nowy przychodzi, a część dzieci pozostaje i w dzieciach nowych, które przychodzą, jest niepokój, i w tych, które zostały jest niepokój, i w tych, które odeszły jest pustka, tak... nawet jeżeli na to miejsce ktoś przyjdzie inny, to wiadomo, że nie przyjdzie ta sama osoba, tylko przyjdzie ktoś inny, z innym bagażem doświadczeń, z innymi potrzebami... I zawsze trzeba na nowo wypracowywać relacje (żona).

Zatem przełamywanie pewnych utartych konwenansów interpretacyjnych prowadzi do konieczności reinterpretacji posiadanej wiedzy oraz zmusza do szukania pasującej interpretacji znaczeń sygnałów i gestów wysyłanych przez partnera interakcji. Generuje to konieczność doboru odpowiednich metod pracy, właściwego sposobu realizacji potrzeb, a także dostosowania charakteru porozumiewania się do dojrzałości

${ }^{16}$ Mowa jest tutaj o kompetencjach pracowników, rozwijanych jeszcze przed podjęciem pracy $\mathrm{w}$ rodzinnym domu dziecka, co następuje w trakcie edukacji szkolnej oraz już po zatrudnieniu, kiedy to pracownik kształtuje umiejętności i kompetencje m.in. komunikacyjne. 
podopiecznego. To z kolei dodatkowo pogłębia trudności w wypracowaniu uniwersalnego i możliwego do ogólnego zastosowania modelu aktu komunikacji.

\section{Rodzaje i sposoby porozumiewania się pracowników z podopiecznymi rodzinnych domów dziecka}

Komunikacja stanowi nieodzowny, a zarazem podstawowy czynnik wszelkich ludzkich działań, także tych, zachodzących między opiekunami i wychowankami RDD. Aby zrealizować jakiekolwiek działania należy posługiwać się zrozumiałym dla partnera interakcji zestawem znaków, które posiadają możliwą do odczytania informację. W danej kulturze istnieje wypracowany na podstawie wspólnych uzgodnień repertuar powszechnie używanych symbolicznych znaczeń sygnałów emitowanych przez przedstawicieli danej społeczności. Również w rodzinnym domu dziecka istnieje charakterystyczny dla tego środowiska zakres symbolicznych kodów językowych. Sposób, w jaki podopieczni rodzinnych domów dziecka przekazują informacje o sobie i swoich potrzebach, a więc komunikują się z innymi ludźmi, ma podstawowe znaczenie w całym, złożonym procesie budowania i utrzymywania relacji społecznych. Stąd niezwykle ważny jest repertuar sygnałów emitowanych przez wychowanków, ale także to, w jaki sposób owe sygnały są odbierane i interpretowane przez pracowników oraz jak ten układ porozumiewania się jest konstruowany i negocjowany w toku wzajemnych relacji.

Na początku warto zwrócić uwagę na próby porozumiewania się z podopiecznymi w dwóch podstawowych kategoriach: komunikacji werbalnej i niewerbalnej. Jak pisze Andrzej Tyszka: „wszelkie rodzaje zachowań stają się równoprawnymi środkami tworzenia i utrzymywania kontaktu lub interakcji pomiędzy ludźmi i ich środowiskiem"17. Nie oznacza to jednak, że taki podział w jakikolwiek sposób wyczerpuje problematykę komunikowania się podopiecznych, na tym ogólnym gruncie bowiem istnieje bardzo wiele specyficznych i danych tej właśnie grupie osób sposobów konstruowania komunikatów werbalnych i niewerbalnych. I to właśnie ową specyfikę czyni się przedmiotem dalszych rozważań.

Niezwykle bogaty jest także repertuar sygnałów niewerbalnych, do których, na podstawie prowadzonych badań w rodzinnym domu dziecka, zaliczyć można: język gestów, dotyk oraz mowę ciała. Zarówno sam sposób ekspresji niewerbalnej, jak również jej symboliczna wymowa jest niezwykle zróżnicowana, zaś funkcje, jakim mogą służyć owe zachowania i sygnały, dotyczą m.in.: wymiany emocji, kształtowaniu i kierowaniu wrażeń, czy wsparciu psychicznemu. W tym kontekście ważnym elementem

\footnotetext{
${ }^{17}$ A. Tyszka, dz. cyt., s. 44.
} 
w procesie komunikowania się, istotnym z punktu widzenia kreowania i uściślania więzi społecznych, jest ciało i sfera cielesności ${ }^{18}$.

Przeważnie maluchy używają gestów i sygnałów niewerbalnych (śmiech), ta więź naturalnie zaczyna się tworzyć, jak przychodzi dziecko przytula się i mówi: „kocham cię ciociu”, albo zapyta „czy mnie kochasz?”. Tak, to jest taki wyznacznik, że coś w tym dziecku zaczyna się zmieniać (żona).

Ciało rozumiane jako przestrzeń komunikacji i porozumiewania się jest zasobnym źródłem informacji o podopiecznym, jej stanie zdrowia, kondycji fizycznej oraz psychicznej czy potrzebach podopiecznego. Jest także wskaźnikiem stanów emocjonalnych. Z drugiej strony, dzieci są bardzo czułe na emocje płynące z otoczenia. Stąd niezwykle ważne jest panowanie opiekuna nad własnymi emocjami, o czym przestrzega Lucyna Miosga, pisząc, że „osoba, przed którą ukrywamy nasze emocje i tak będzie je odczuwała. Będzie odbierała nasz smutek czy złość poprzez mowę ciała, poprzez nasz głos [...]. Może to spowodować wycofanie lub unikanie przez nią kontaktu, a także zachwianie poczucia bezpieczeństwa"19. Wniosek ten potwierdza poniższa wypowiedź:

Dzieci są wspaniałymi psychologami i jeżeli jestem w stresie, to nie jestem w stanie tego ukryć. Dzieci to czują i to jest dla nich dyskomfort. I teraz myślą: albo one coś zawiniły, albo coś złego się dzieje, jest niepokój, jest zaburzenie poczucia bezpieczeństwa i zaczyna nakręcać się koło (mąż).

Ciało jest komunikatem wiarygodnym także dlatego, że nie poddaje się wpływom danej osoby. Zmiany na ciele, oznaki zmęczenia, choroby itd. są sygnałami dla pracowników, informującymi o tym, co aktualnie dzieje się z wychowankiem.

Dziewczynka cięła się od kilku lat, całe ręce miała pocięte i napędzała ją do tego jej ulubiona lektura „My dzieci z dworca ZOO”. Po paru latach wspólnego mieszkania przestała się ciąć, ale po każdym chłopaku, z którym się rozstawała, musiała pozostawić ślad nienawiści na swoim ciele, np. samodzielnie wykonany tatuaż lub kilkunasty kolczyk (żona).

Ciało niejako „mówi” otoczeniu o danej osobie, ale jest także źródłem ekspresji, sposobem wyrażania siebie. Jest emanacją tożsamości wychowanka, który ową tożsamość po części kreuje. Jednocześnie to, co podopieczny robi ze swoim ciałem, jest objawem tego, czego aktualnie potrzebuje, czego mu brakuje lub tego, czego w danej chwili chce bądź oczekuje od otoczenia. Ciało jako źródło komunikatów, ma zatem dwa wymiary: pierwszy, dotyczący naturalnych przemian fizjologicznych, niezależnych od podopiecznego, drugi to przestrzeń działania wychowanka.

Podsumowując dotychczasowe rozważania na temat sposobu oraz charakteru porozumiewania się pracowników z podopiecznymi, można powiedzieć, że rola ko-

${ }^{18}$ L. Miosga, Pomóż mi być. Komunikacja i stymulacja zmysłowa osób ze znaczną i głęboką niepetnoprawnościa umystową, Oficyna Wydawnicza Impuls, Kraków 2005, s. 13.

19 Tamże, s. 11-12. 
munikacji nabiera szczególnego znaczenia w tworzeniu się i utrzymywaniu relacji w rodzinnym domu dziecka. Relacje tworzą się w momencie, gdy zaczynają się interpersonalne stosunki poprzez dotyk, ton głosu, gest, wyraz twarzy, a potem przez mowę i jej rozumienie20. Przy czym wymagania stawiane przed opiekunami wymuszają na nich konieczność dostosowania komunikatów zarówno werbalnych, jak i niewerbalnych do wieku i dojrzałości każdego dziecka oraz ciągłego doskonalenia umiejętności komunikacyjnych.

\section{Reguły komunikowania się w rodzinnym domu dziecka}

W rodzinnym domu dziecka istotne znaczenie mają umiejętności interpersonalne oraz wiedza pracownika, tym bardziej, że tworzenie poprawnych relacji z podopiecznym, wymaga od pracowników znacznego zaangażowania emocjonalnego oraz wczucia się w sytuację dziecka. Te okoliczności są jednocześnie sprawdzianem umiejętności dla pracowników, zaangażowanych w szereg czynności i obowiązków zawodowych związanych z podopiecznymi. Wszelkie działania podejmowane przez pracowników w kierunku utrzymania należytego stanu zdrowia fizycznego oraz psychicznego, a także komfortu emocjonalnego podopiecznych będą możliwe, jeśli zostanie z nimi nawiązany, a następnie podtrzymywany właściwy kontakt. To, w jakim zakresie uda się zrealizować stawiane przed pracownikami zadania, bezpośrednio związane jest z jakością procesu porozumiewania się z podopiecznymi. Proces ten będzie bardziej efektywny, jeśli pracownik posiada odpowiednie predyspozycje czy też odznacza się określonymi cechami charakteru i osobowości. Jest to uwarunkowane psychiką opiekuna, jego zdolnościami do neutralizowania emocji, cierpliwością, wytrwałością, a także empatycznym nastawieniem do podopiecznych.

Trzeba mieć dużo cierpliwości i empatii. Naszej najmłodszej córce, kiedy nagle przestała być najmłodsza, bo przychodziły młodsze dzieci, musieliśmy wytłumaczyć, że to jest nasza praca, dzięki temu ja jestem z tobą w domu cały czas, nie chodzę do pracy, coś za coś, inaczej chodzilibyśmy z tatą do pracy, ty siedziałabyś po lekcjach w świetlicy, takie są pewne plusy i minusy, tak wygląda życie, to jest moja praca, ja pracuję w domu, ja jestem w domu do twojej dyspozycji przez cały czas, ale też pracuję i opiekuję się innymi dziećmi (żona).

Na pracowniku ciąży zatem największa odpowiedzialność za jakość życia wychowanka. Z tego względu, aby w jak największym stopniu zapewnić efektywność działań opiekunów oraz umożliwić skuteczność w zakresie komunikowania się z podopiecznymi, pracownicy powinni jak najszybciej ustalić reguły i zasady, na jakich opiera się poprawność aktu porozumiewania się. Reguły związane $\mathrm{z}$ aktem komunikowania się pracowników z podopiecznymi można podzielić na następujące kategorie. Po pierw-

20 A. Piotrowski, Ład interakcji. Studia z socjologii interpretatywnej, Wydawnictwo Uniwersytetu Łódzkiego, Łódź 1998, s. 26. 
sze, są to reguły techniczne, dotyczące samego sposobu wypowiadania i wysławiania się pracowników. W większości wypadków za niezbędne w procesie porozumiewania uznaje się zrozumiały język dla dziecka oraz powolne i spokojne mówienie. Oto jedna z wypowiedzi:

Pierwszej rzeczy, której musieliśmy się wyzbyć z mężem, to działanie pod wpływem emocji i zdenerwowania. Podniesiony głos w niczym nam nie pomagał. Wiedzieliśmy o tym, ale uczyliśmy się tego stopniowo (żona).

Druga kategoria odnosi się do funkcji słuchania i obserwowania podopiecznego przy jednoczesnym minimalizowaniu własnej aktywności opiekuna. Kolejną grupę stanowią reguły dotyczące charakteru treści komunikatów. Kategoria ta sprowadza się do zasady „mów to, co możesz powiedzieć” oraz „mów to, co wyzwala pozytywne emocje, a unikaj tego, co może wywołać negatywne”. Oznacza to, w pierwszym przypadku, że pracownik powinien posiadać świadomość wieku oraz dojrzałości podpieczonego i starać się dostosować zarówno treść, jak i formę wypowiedzi do indywidualnych zdolności danej osoby. Druga z wymienionych zasad wiąże się natomiast z dbałością o stan emocjonalny danej osoby. Wiąże się to z koniecznością bycia czujnym, a także selektywnego wyboru i dostosowania do danych okoliczności oraz sytuacji, wypowiedzi pracownika, tak aby nie wywoływać niepotrzebnych emocji. Przykładem jest poniższa wypowiedź:

Lepiej jest nie tłumaczyć dzieciom, dlaczego ich rodzice nie przyjechali. To, co będziemy chcieli przetłumaczyć, może się okazać nieprawdziwe i potem dziecko buduje obraz: ta ciocia też kłamie. To nie tylko moja mama kłamie, ale ciocia też kłamie. A my chcemy w dobrej wierzy wymyślić sobie jakąś odpowiedź na tę sytuację. Najlepiej wtedy milczeć, pozwolić dziecku poszukać jakiegoś zajęcia, żeby mogło się czymś zająć żeby, oderwać go od tego stania oczekiwania w oknie (żona).

Wszystkie wspomniane wyżej reguły mają bezpośredni wpływ na charakter porozumiewania się pracowników z podopiecznymi. Należy przy tym pamiętać, że dotyczą one bezpośrednio pracowników, ponieważ to na nich właśnie ciąży obowiązek realizacji potrzeb podopiecznych, a także odpowiedzialność za ich ogólnie pojęte dobro osobiste.

\section{Zakończenie}

Zasadniczym celem artykułu było przedstawienie problematyki porozumiewania się pracowników z podopiecznymi jako procesu budowania i podtrzymywania relacji $\mathrm{w}$ rodzinnym domu dziecka. W związku $\mathrm{z}$ tym podjęto próbę przedstawienia specyfiki i charakteru wzajemnych oddziaływań aktywnie współuczestniczących aktorów w kontekście relacji interpersonalnych w społecznej przestrzeni rodzinnych domów dziecka. Z tego względu głównym zadaniem było poszukanie odpowiedzi na pytanie: 
„Jakie znaczenie ma porozumiewanie się w procesie budowania i podtrzymywania relacji pracowników z podopiecznymi w rodzinnym domu dziecka?”. Na podstawie przeprowadzonych analiz udało się ustalić kilka wniosków dotyczących wielu aspektów porozumiewania się pracowników z podopiecznymi rodzinnych domów dziecka, co starałam się wykazać poniżej.

Przede wszystkim należy wziąć pod uwagę czynniki wpływające na charakter procesu komunikowania się. Porozumiewanie się przedstawicieli tych grup ma dwa wymiary: instrumentalny oraz emocjonalny. O wymiarze instrumentalnym mówimy, gdy mamy na myśli techniczne i proceduralne cechy komunikacji. W wymiarze emocjonalnym mamy natomiast do czynienia z pogłębioną analizą sygnałów emitowanych przez podopiecznych. Co więcej, chodzi w tym przypadku także o fakt obdarzania uczuciami podopiecznego przez pracownika i odwrotnie. Oznacza to, że więź emocjonalna, istniejąca pomiędzy pracownikiem i podopiecznymi, jest tworzona i podtrzymywana za pośrednictwem całej gamy symbolicznych komunikatów.

Wszelkie działania podejmowane przez opiekunów w kierunku utrzymania należytego stanu zdrowia fizycznego i psychicznego będą możliwe, jeśli zostanie nawiązany i podtrzymywany kontakt z podopiecznym. To, w jakim zakresie uda się zrealizować stawiane przed pracownikiem zadania, będzie więc bezpośrednią konsekwencją umiejętności porozumiewania się z podopiecznymi. Istotne są więc zdolności interpersonalne oraz praktyczna wiedza, tym bardziej, że zbudowanie poprawnych relacji $\mathrm{z}$ podopiecznym wymaga od pracownika znacznego zaangażowania się $\mathrm{w}$ relacje interpersonalne oraz wczucia się w sytuację podopiecznych.

\section{Bibliografia}

Baraniewicz D., Baraniewicz M., Możliwości komunikacyjne uczniów z głębokim upośledzeniem umysłowym, [w:] J. Baran, A. Mikruta (red.), Umiejętności komunikacyjne osób zniepetnosprawnościa: teoria, diagnoza, wspomaganie, Wydawnictwo Naukowe Akademii Pedagogicznej, Kraków 2007.

Kazimierska K., Wywiad narracyjny - technika i pojęcia analityczne, [w:] M. Czyżewski, A. Piotrowski, A. Rokuszewska-Pawełek (red.), Biografia a tożsamość narodowa, Katedra Socjologii Kultury Uniwersytetu Łódzkiego, Łódź 1997.

Konecki K., Praca w koncepcji socjologii interakcjonistycznej, „Studia Socjologiczne”, nr 1/1988.

Kubinowski D., Jakościowe badania pedagogiczne, Wydawnictwo Uniwersytetu Marii Curie-Skłodowskiej, Lublin 2010.

Kvale S., Prowadzenie wywiadów, Wydawnictwo Naukowe PWN, Warszawa 2010.

Lalak D., Podejście biograficzne w naukach o wychowaniu, [w:] S. Palka (red.), Podstawy metodologii badań w pedagogice, Wydawnictwo Akademickie "Żak”, Gdańsk 2010. 
Miosga L., Pomóż mi być. Komunikacja i stymulacja zmysłowa osób ze znaczną i głęboka niepetnoprawnością umysłową, Oficyna Wydawnicza Impuls, Kraków 2005.

Nęcki Z., Komunikacja międzyludzka, Wydawnictwo Profesjonalnej Szkoły Biznesu, Kraków 1996.

Pilch T., Bauman T., Zasady badan pedagogicznych, Wydawnictwo Akademickie „Żak”, Warszawa 2010.

Piotrowski A., Ład interakcji. Studia z socjologii interpretatywnej, Wydawnictwo Uniwersytetu Łódzkiego, Łódź 1998.

Rozporządzenie Ministra Pracy i Polityki Społecznej w sprawie placówek opiekuńczo-wychowawczych z dnia 14.02.2005 r. (Dz.U. Nr 37, poz. 331).

Rozporządzenie Rady Ministrów o pomocy społecznej z dnia 12.03.2004 r. (Dz.U. Nr 64, poz. 593).

Silverman D., Prowadzenie badań jakościowych, Wydawnictwo Naukowe PWN, Warszawa 2008.

Tyszka A., Rozmowa kultur, [w:] A. Kapciak, L. Korporowicz, A. Tyszka (red.), Komunikacja międzykulturowa - zbliżenia i impresje, Wydawnictwo Instytutu Kultury, Warszawa 1995.

\section{The communication between staff and children as a process in building and maintaining relationships in the family foster home}

Abstract: The paper presents, in a descriptive way, the problem of communication between staff and children as a process of building and maintaining relationships in the family foster home. The author highlights the importance of communicating in the family foster home and presents the results of narrative interviews. The approach of a married couple, who took care of several children who were taken away from their parents on the orders of a court, is interesting. The paper describes the communication between the staff and the children from the family foster home, the problems they encountered and how they dealt with the problems. The results of the biographic studies are divided into a few subtopics and include, among other things, the types and methods of communication between the staff and children as well as rules of communication in the family foster home.

Keywords: communications, relationships, substitute care, family foster home

About the author: Agnieszka Deja, MA, Second-year PhD student of pedagogy, Social Sciences Faculty, University of Gdańsk. Bachelor: pedagogical care and pedagogy with pedagogical therapy. Masters: social pedagogy. Interests: substitute care, family forms of foster care, family foster home, symbolic interactionism. 


\title{
Karolina Kołodziejczak* (iD https://orcid.org/0000-0002-9953-5245
}

Uniwersytet Jagielloński

\author{
Katarzyna Smoter $^{* *}$ (D) https://orcid.org/0000-0001-5180-6344
}

\section{Portret polskich millenialsów w twórczości muzycznej Taco Hemingwaya}

\begin{abstract}
Streszczenie: Celem artykułu jest rekonstrukcja obrazu polskich millenialsów w piosenkach Taco Hemingwaya. Ukazano tu wyniki analiz zrealizowanych metodą analizy treści w paradygmacie interpretatywnym. Ich przedmiotem stały się teksty piosenek zawarte na minialbumach „Trójkąt warszawski” (2014) i „Umowa o dzieło” (2015). Z analizowanych tekstów wyłania się obraz przedstawicieli pokolenia millenium postrzeganych jako konsumenci, osoby ambiwalentne (z jednej strony mocno sceptyczne, z drugiej - idealistyczne), „cyfrowych tubylców”, „poszukiwaczy wrażeń” i prekariuszy. Analiza treści piosenek autora, który określa się „głosem pokolenia, które nie ma nic do powiedzenia” stanowi ważny przyczynek do podjęcia refleksji na temat charakterystyk millenialsów, ich potrzeb, wyznawanych przez nich opinii i poglądów. Przedstawiony problem rodzi także implikacje pedagogiczne - tym samym, znaczące staje się zasygnalizowanie pewnych obszarów naukowej refleksji.
\end{abstract}

Słowa kluczowe: millenialsi, portret, muzyka, Taco Hemingway

\footnotetext{
* Karolina Kołodziejczak - doktorantka w Instytucie Pedagogiki Uniwersytetu Jagiellońskiego, absolwentka pedagogiki społeczno-opiekuńczej, pedagogiki szkolnej z terapią pedagogiczną i pedagogiki specjalnej o specjalności resocjalizacja na Uniwersytecie Jagiellońskim. Zainteresowania naukowe: recepcja muzyki, aktywne uczestnictwo w kulturze muzycznej i jego pedagogiczne implikacje, radio, pedagogika szkolna.

** Katarzyna Smoter - doktor nauk społecznych w dyscyplinie pedagogika, absolwentka pedagogiki opiekuńczo-wychowawczej i socjologii na Uniwersytecie Jagiellońskim. Zainteresowania naukowe: edukacja międzykulturowa, dydaktyka, edukacja antydyskryminacyjna, pedeutologia, edukacja w szkole wyższej, kultura popularna.
} 


\section{Wstęp}

Młodzież nie stanowi homogenicznej grupy, pojmować ją raczej należy jako charakteryzującą się dużym indywidualnym zróżnicowaniem. W związku z tym, pojawiają się głosy, w których podkreśla się niemożność ujednolicania tej kategorii i sprowadzania jej przedstawicieli do zbioru kategorycznie ujętych cech. Z drugiej strony warto zauważyć, że wzrastanie, któremu towarzyszy ten sam społeczno-kulturowy kontekst może powodować, że „ludzie kierują się w pewnych wspólnie przeżywanych warunkach tymi samymi wartościami, zakodowanymi uprzednio w ich wewnętrznej substancji podmiotowej"1. Z tego może wynikać podobieństwo przedstawicieli młodego pokolenia, określanych w literaturze przedmiotu jako m.in.: digital natives, pokolenie C, pokolenie Y czy millenialsi.

W jednej z interpretacji młodzież bywa rozumiana jako „zwierciadło” ukazujące najważniejsze problemy epoki ${ }^{2}$. Łączy się to $z$ takimi jej cechami, jak: wrażliwość na procesy społeczne, chłonność na innowacje w sferze wartości, ideologii, przemian obyczajowych i technologii, łatwość adaptowania się do nowych sytuacji. Znaczący staje się tutaj także aspekt biologicznej i duchowej witalność młodości, która sprawia, że co pewien czas odmienia się postać świata. Takie ujęcie młodzieży, postrzeganej jako podmiot przeobrażeń społecznych, podkreślane jest m.in. na gruncie pedagogiki młodzieży. W odniesieniu z kolei do analiz dotyczących przeobrażeń zachodnich społeczeństw, należy zauważyć, że młodzież pochodząca z państw europejskich nie różni się od siebie w znaczący sposób ${ }^{3}$. Dotyczy to także adolescentów pochodzących z Polski. Warto jednak zauważyć, że uwidaczniają się tu jednak pewne rozbieżności, wynikające z odmiennych pod wieloma względami przemian historycznych, kulturowych czy światopoglądowych występujących w naszym kraju. Wśród nich warto wskazać np. na: obecną po 1989 roku modernizację imitacyjną, stosunkowo „młody” charakter przemian demokratycznych w Polsce, stan rozwoju społeczeństwa obywatelskiego czy zachodzące w ostatnich czasach dynamicznie procesy laicyzacji. Zarysowane tu obszary oddziałują na specyfikę młodego pokolenia w Polsce, nadając im swoistą postać. Za wyróżnianie się w procesie wymiany pokoleń i wyjątkowość polskich millenialsów odpowiadają czynniki o charakterze globalnym, takie jak: podleganie zakresowi oddziaływań bodźców zewnętrznych, będących konsekwencją dominacji kultury konsumpcyjnego kapitalizmu i rozwoju cywilizacyjnego, czy uleganie różnym formom uzależnień, a także czynniki regionalne, m.in. specyficzne wy-

${ }^{1}$ K. Kluz, K. Slany, Kształtowanie systemu wartości jako kierunek działań polityki ludnościowej, [w:] D. Graniewska (red.), Sytuacja rodzin i polityka rodzinna w Polsce, Instytut Pracy i Spraw Socjalnych, Warszawa 2004, s. 110.

2 M. Niezgoda, Młodzież. Kłopotliwa kategoria socjologiczna, „Jagiellońskie Studia Socjologiczne", nr 1/2014, http://ejournals.eu/sj/index.php/ISB/article/view/1 (dostęp: 26.02.2018).

3 Zob. Z. Melosik, Kultura popularna jako czynnik socjalizacji, [w:] Z. Kwieciński, B. Śliwerski (red.), Pedagogika. Podręcznik akademicki, cz. 2, Wydawnictwo Naukowe PWN, Warszawa 2003. 
korzenienie z historii ${ }^{4}$. Dzięki połączeniu tych czynników, współczesna polska młodzież tworzy nową jakość tożsamości społecznej pokolenia, wzmacnia swoje poczucie przynależności i w nietradycyjny sposób afiszuje rozpoznawalne właściwości własnej grupy pokoleniowej. W. Wrzesień określa pokolenie polskiej młodzieży „Pochłaniaczami Bodźców"5 (na marginesie można dodać, iż to sformułowanie wydaje się być adekwatne także w kontekście prowadzonych przez nas analiz tekstów muzycznych).

$\mathrm{Na}$ potrzeby tego artykułu uznałyśmy, że rekonstrukcja cech millenialsów jest możliwa poprzez interpretację ich wytworów artystycznych, zwłaszcza tych, stanowiących swoisty „manifest pokoleniowy”. Interesującym przykładem będą tu teksty piosenek popularnych przedstawicieli kultury młodzieżowej. Wydają się one być odzwierciedleniem tego, co w danym okresie interesuje młodych ludzi, dając też „odpowiedź zwrotną” społeczeństwu na temat tego, co jest dla nich wartościowe ${ }^{6}$. Wychodząc z takich założeń, za cel tego artykułu obrałyśmy rekonstrukcję obrazu polskich millenialsów w piosenkach Taco Hemingwaya. Zagadnienie to staje się istotne ze względu na popularność twórczości tego wykonawcy i utożsamianie się z tekstami jego piosenek wielu przedstawicieli pokolenia młodzieży i młodych dorosłych ${ }^{7}$.

W artykule ukazane zostaną wyniki analiz realizowanych metodą analizy treści $\mathrm{w}$ paradygmacie interpretatywnym. Ich przedmiotem stały się teksty piosenek zawarte na minialbumach „Trójkąt warszawski” (2014) i „Umowa o dzieło” (2015). Obszar twórczości Taco Hemingwaya staje się znaczący ze względu na obecność w niej wątków przypisywanych przedstawicielom „starszej młodzieży” - millenialsom. Ta liczna grupa w zauważalnym stopniu oddziałuje na procesy społeczno-gospodarcze i godna jest refleksji naukowej. Analiza tekstów piosenek autora, który określa się „głosem pokolenia, które nie ma nic do powiedzenia" może stanowić zatem przyczynek do podjęcia refleksji na temat posiadanych przez millenialsów potrzeb oraz wyznawanych przez nich opinii i poglądów.

${ }^{4}$ W. Wrzesień, Pokoleniowość współczesnej polskiej młodzieży „Władza Sądzenia”, nr 7/2015, s. $37-55$.

5 Tamże.

${ }^{6}$ M. Zawadzki, Komunikacja werbalna i niewerbalna subkultury satanistów i metalowców. Podobieństwa i różnice obu grup, [w:] Z. Pasek (red.) Ezoteryzm, okultyzm, satanizm w Polsce, Wydawnictwo Libron, Kraków 2005, s. 191.

${ }^{7}$ Fenomen popularności tego rapera jest opisywany na wielu portalach. Zob. np.: To jest ten rap dla meneli i dla koneserów, https://www.dailyvibes.pl/single-post/taco-hemingway-fenomengatunku, Dlaczego ludzie jarają się Taco Hemingwayem?, https://www.vice.com/pl/article/bn9xmz/ dlaczego-ludzie-jaraja-sie-taco-hemingwayem (dostęp: 8.04.2018).

${ }^{8}$ Fragment piosenki Taco Hemingwaya „Wosk”. 


\section{W tym pokoleniu na umowie-zleceniu... Taco Hemingway i millenialsi}

Obecna na gruncie nauk społecznych kategoria „pokolenie” uwidacznia się szczególnie w obszarze subdyscyplin takich, jak: socjologia młodzieży czy pedagogika społeczna. W ostatnich latach problematyce pokolenia uwagę poświęcali m.in.: E. Wysocka (2014), J. Morbitzer (2012) czy D. Hildebrandt-Wypych (2009) omawiający fenomen medialności reprezentantów młodego pokolenia, czy przeobrażeń ich religijności. W niniejszym artykule będziemy odnosić się szczególnie do cech pokolenia millenium (określanego jako Net Generation, pokolenie Y, Facebookers i Thumb Generation), dotyczącego osób urodzonych między 1976 a 2000 rokiem $^{9}$ (a ściślej: między 1980 a 1995 ${ }^{10}$. Opis tej kategorii ukazywany jest często w kontekście przystosowania jej przedstawicieli do rynku pracy czy tworzonych przez nich związków miłosnych ${ }^{11}$. Z kolei w literaturze przedmiotu, wśród cech przypisywanych reprezentantom tej grupy wskazuje się przede wszystkim na:

- Ich elastyczność, otwartość na doświadczenia, niezależność oraz sceptycyzm. Postrzega się ich także jako przedstawicieli pokolenia przesytu konsumpcyjnego ${ }^{12}$.

- Ich nierealistyczne oczekiwania, zbytnią pewność siebie (wręcz narcyzm) i potrzebę bycia chwalonym. To pokolenie ukształtowane przez rozwój technologii, wykształcone, znające języki obce, nie obawiające się wyzwań. Podkreśla się ich lojalność wobec pracodawców, a z drugiej strony tendencję do częstej zmiany pracy, motywowanej chęcią lepszego zarobku lub poczuciem niedocenienia ${ }^{13}$.

- Ich optymizm, idealizację otaczającej rzeczywistości, różnorodność, ambicje, kreatywność, inicjatywę, innowacyjność oraz nastawienie na edukację i indywidualny rozwój ${ }^{14}$.

9 A. Dziopak-Strach, Pokolenie Y wyzwaniem dla działów HR, ZN WSH „Zarządzanie”, nr 2/2016, s. 48.

10 Tamże.

${ }^{11}$ Zob. Kac morderca. Zmora pokolenia Y?, http://www.newsweek.pl/styl-zycia/kac-morderca-jak-mlodzi-polacy-radza-sobie-z-porannym-bolem-glowy-,artykuly,367837,1.html, Millenialsi: Czy pójdą na wybory? Czy znowu zadecydujq o ich wyniku?, http://www.newsweek.pl/polska/millenialsi-czy-pojda-na-wybory-na-kogo-zaglosuja-,artykuly,372706,1.html, Młody wyszedł zbańki, https://www.polityka.pl/tygodnikpolityka/kultura/1716078,1,jak-trafic-do-pokolenia-milenialsow. read, Niskooburzeni, https://www.polityka.pl/tygodnikpolityka/spoleczenstwo/1535433,1,millenialsi--mile-pokolenie-bez-zludzen.read (dostęp: 8.04.2018).

${ }^{12}$ H. Rusek, Wspótczesne młode pokolenie jako wyzwanie dla socjalizacji i wychowania, [w:] T. Lewowicki, A. Szczurek-Boruta, B. Grabowska (red.), Przemiany społeczno-cywilizacyjne i edukacja szkolna - problemy rozwoju indywidualnego i kształtowania się tożsamości, Oficyna Wydawnicza Impuls, Kraków 2005, s. 262.

${ }_{13}$ A. Dziopak-Strach, dz. cyt.

${ }_{14}$ A. Gruszka, Cyfrowi tubylcy wchodza do gry, http://marketing.org.pl/archiwum/index.php/ go=2/act=2/aid=m55c13eb5cfae3 (dostęp: 15.03.2018). 
- Ich wytrwałość, przedsiębiorczość, tolerancję, zorientowanie na cel, nastawienie na multitasking. Praca postrzegana jest przez nich jako „środek do celu”, zabiegają o równowagę między życiem prywatnym a pracą. Millenialsi praktykują partycypacyjny styl interakcji ${ }^{15}$.

Warto wspomnieć, że równie często w literaturze przedmiotu pojawiają się ujęcia określające ich jako: pokolenie prekariatu, „poszukiwacze wrażeń”, czy „cyfrowi tubylcy”16. Przedstawione wyżej „zestawienia” cech millenialsów ukazują niejednoznaczność podejść do reprezentantów tej grupy. Przyczynia się to do powstania trudności w konstrukcji wykazu „listy” cech przypisywanych przedstawicielom tej kategorii.

Niektóre $z$ wymienionych cech znajdują swój wyraz w twórczości „hipsterskiego rapera” Taco Hemingwaya. Jego dyskografia obejmuje osiem albumów: „Young Hems”

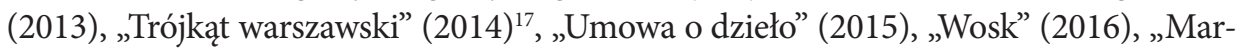
mur” (2016), „Szprycer” (2017), „Cafe Belga” (2018), „Flagey” (2018). Popularność tego rapera obrazuje wysoki nakład jego płyt, jak i liczba wyświetleń jego piosenek w serwisach Youtube i Spotify (w tegorocznym rankingu Spotify TOP 5 wśród polskich fanów muzyki, Taco Hemingway zajął drugie miejsce) ${ }^{18}$.

Wydane przez Hemingwaya albumy „Trójkąt warszawski” i „Umowa o dzieło” w ujęciu krytyków muzycznych i fanów tego wykonawcy stanowią powiązaną ze sobą całość. „Trójkąt warszawski” to zapis historii trojga bohaterów, którzy próbują odnaleźć się w wielkomiejskim życiu nocnym. „Umowę o dzieło” traktować można z kolei jako "listy z codzienności”, historie z nocnych lokali, wynajmowanych mieszkań oraz wagonów metra ${ }^{19}$. Taco, „rocznikowo” przedstawiciel millenialsów, opisuje osobiste doświadczenia i komentuje wybory egzystencjalne swoich rówieśników. Poruszana przez niego tematyka sprawia, że bywa on określany przez dziennikarzy jako głos pokolenia dwudziestoparolatków z dużych miast, a także „sumienie prekariatu”20.

${ }^{15}$ FDU Magazine, Mixing and Managing Four Generations of Employees, http://www.fdu.edu/ newspubs/magazine/05ws/generations.htm (dostęp: 7.03.2018).

${ }^{16}$ A. Armatys, Rozkochać pokolenie Y. Grywalizacja w procesie budowania marki, https:// www.sointeractive.pl/blog/rozkochac-pokolenie-y-grywalizacja-w-procesie-budowania-marki/; A. Black, Gen Y: Who They Are and How they Learn, „Educational Horizons” 2010, vol. 88, no. 2, s. 94; M. Andrejczuk, Prekariat a „pokolenie Y", zjawisko prekaryjności młodych pracowników, http:// scholar.com.pl/upload/product files/2714/587 04 kir 2017 2 .pdf (dostęp: 8.04.2018).

${ }^{17}$ Jak opisuje Taco Hemingway w utworze Od zera: „Śpiące życie trochę mi się po »Trójkącie» ocknęło".

${ }^{18}$ https://noizz.pl/muzyka/spotify-ranking-najczesciej-sluchani-artysci-2017-roku-wedlug-spotify/2l5mfmz (dostęp: 25.12.2017).

${ }_{19}$ Zob. https://kultura.onet.pl/muzyka/gatunki/hip-hop/taco-hemingway-umowa-o-dzielo -recenzja/0wkydr8 (dostęp: 8.04.2018).

20 Tamże. 


\section{Metodologia badań}

Analiza ujmowanego $\mathrm{w}$ artykule zagadnienia wymagała zastosowania metody analizy treści, odnosiła się ona do paradygmatu interpretatywnego postulującego naturalistyczne podejście do świata ${ }^{21}$.

W toku analizy, znaczące stało się ustalenie, które z cech przypisywanych millenialsom obecne są w tekstach Taco Hemingwaya i w jaki sposób są one przez tego autora przedstawiane. Realizacja celu głównego wymagała podjęcia następujących kroków analizy:

- kilkukrotnego odsłuchania utworów zawartych na obu płytach,

- transkrypcji tekstów,

- stworzenia drzewa kodowego uwzględniającego charakterystyki przyporządkowywane

- kategorii „millenialsi”.

Trzeci z etapów wiązał się z problematycznością wyodrębnienia kategorii cechujących reprezentantów pokolenia millenium. Warto zauważyć, że obecne w literaturze przedmiotu określenia millenialsów nie zawsze są ze sobą spójne (np. sceptycyzm w innych ujęciach jest zastępowany optymizmem czy idealizmem). Ostatecznie wyodrębniono pięć kategorii dookreślonych na poziomie późniejszej analizy:

- millenialsi postrzegani w odniesieniu do ich konsumpcjonizmu;

- millenialsi postrzegani jako "ambiwalentni" - rozpięci między idealizmem a sceptycyzmem;

- millenialsi postrzegani jako e-pokolenie (digital natives);

- millenialsi postrzegani jako „poszukiwacze wrażen”;

- millenialsi postrzegani jako przedstawiciele prekariatu.

Kolejnym etapem stało się kodowanie tekstów muzycznych metodą descriptive coding and holistic coding (cel: uchwycenie wątków obecnych w analizowanych utwo(rach) $)^{22}$.

Następnie utworzono notatki dotyczące tekstów muzycznych.

Ostatnim etapem stała się analiza jakościowa ujętych wątków i sformułowanie wniosków na podstawie zakodowanych fragmentów i stworzonych notatek.

Analizie badawczej poddano treści tekstów piętnastu utworów słowno-muzycznych znajdujących się na płytach „Trójkąt warszawski” (2014) i „Umowa o dzieło” (2015).

${ }^{21}$ N.K. Denzin, Y. S. Lincoln (red.), Metody badań jakościowych, t. 1, Wydawnictwo Naukowe PWN, Warszawa 2009, s. 23.

${ }^{22}$ J. Saldaña, The coding manual for qualitative researchers, CA, Sage Publications Ltd, Thousand Oaks 2009, s. 70. 


\section{Konsumpcjonizm millenialsów w tekstach Taco Hemingwaya}

Termin „społeczeństwo konsumpcyjne” odnosi się do stanu kultury zachodnich społeczeństw, którego coraz więcej obszarów jest podporządkowana mechanizmom rynkowym ${ }^{23}$. Globalny system gospodarczy można określić „gospodarką doznań i przeżyć”, w której każda czynność wspomagana zachowaniami konsumenckimi tworzyć ma fascynujący projekt życiowy ${ }^{24}$. Kulturę konsumpcji uznaje się za ważną perspektywę postrzegania zjawisk społecznych, generującą powstanie moralności ukierunkowanej na przyjemność i obowiązek bycia szczęśliwym ${ }^{25}$. Konsumpcja upodabnia do siebie przedstawicieli pokolenia, korzystających z podobnych produktów i usług. Jak zauważa Z. Bauman: „Konsumować to [...] inwestować we własne członkostwo w społeczeństwie"26. W odniesieniu do analizy tekstów należy zauważyć, że w utworach Taco Hemingwaya uobecniają się następujące konsumenckie schematy postępowania:

- odnoszone do relacji seksualnych;

- dotyczące posiadania „przedmiotów pożądania” i materialistycznego stylu życia, także takiego, w którym konsumpcja łączy się ze spełnianiem wytycznych dotyczących prozdrowotnej diety czy aktywności fizycznej ${ }^{27}$.

Pierwszy typ konsumpcjonizmu opisuje zorientowanie na bliskie ujmowanej przez T. Szlendaka supermarketyzacji, pojmowanie seksualności „wyzwolonej” od wymogu reprodukcji, skoncentrowanej na poszukiwaniu doznań2 ${ }^{28}$. Trend ten ilustruje fragment tekstu dotyczący przygody erotycznej opisywanych bohaterów:

Jakiś typek mnie szuka, twierdzi, że skradłem mu żonę. No ale wiesz co mówią, znalezione nie kradzione („A mówiłem Ci”).

Cytat ten podkreśla epizodyczność relacji miłosnych (ukraść, w tym rozumieniu, można to, co się posiada, $\mathrm{z}$ czym się jest trwale związanym ${ }^{29}$ ). Opisywana $\mathrm{w}$ ten sposób „tymczasowa kochanka” jest przedmiotem w relacjach „damsko-męskich”, w których dochodzi do szybkiego porzucania, a właściwie „przerzucania” między sobą

${ }^{23}$ A. Jawłowska, Miejsce Wartości w świecie reklamy, [w:] A. Jawłowska-Konstanciak, J. Mariański (red.), Kondycja moralna społeczeństwa polskiego, Wydawnictwo WAM, Kraków 2002, s. 351.

${ }^{24}$ E. Bendyk, Zęby w bawetnie, [w:] Niezbędnik inteligenta, „Polityka”, 16.12.2006, nr 50, s. 34.

${ }^{25}$ Z. Melosik, dz. cyt.

${ }^{26}$ Z. Bauman, Konsumowanie życia, Wydawnictwo Uniwersytetu Jagiellońskiego, Kraków 2009, s. 65.

${ }_{27}$ R.W. Dworkin, Nowa ewangelia zdrowia, [w:] P. Sztompka, M. Bogunia-Borowska, Socjologia codzienności, Wydawnictwo Znak, Kraków 2008.

${ }^{28}$ T. Szlendak, Leniwe maskotki, rekiny na smyczy, Wydawnictwo Czarna Owca, Warszawa 2005, s. 33.

${ }^{29}$ Millenialsów opisuje się jako osoby ceniące dostęp do produktów, co niekoniecznie dotyczy chęci posiadania ich na własność, https://home.kpmg.com/content/dam/kpmg/uk/pdf/2017/04/ Meet-the-Millennials-Secured.pdf (dostęp: 8.04.2018). 
partnerów. W tekstach Taco Hemingwaya przedstawiono typ relacji, w której kobiety i mężczyźni to towary, po które można sięgnąć w każdej chwili:

Będziesz Iriną, a ja Ronaldo. Sprawdzę czy są prawdziwe, czy silikon jak w Palo Alto („A mówiłem Ci”).

Przyjęcie tej perspektywy skutkuje przygodnością tego typu związków. Inni są oceniani na podstawie przyjemności, jakiej mogą dostarczyćc ${ }^{30}$. Tego typu nastawienie ilustruje następujący fragment, opisujący „podboje miłosne” millenialsów:

Nosi rury i szpilki, on kupuje jej drinki i wertuje klucze w płaszczu, robiąc głośny klekot. Usta tamtej uchylone a jej wzrok prosi o jego wnętrzności, bierze oddech i się pierś wznosi („Wszystko jedno”).

Kontakty międzyludzkie bywają organizowane dzisiaj według wzoru działania restauracji fast food, co znajduje swój wyraz w schemacie: „wchodzę - wychodzę nigdy mnie tu nie było”31. Ta tendencja jest ukazana w tekście „Trójkąt”, obrazującym schemat zawierania „szybkich związków”. Autor podsumowuje to następująco: „Możesz wejść na chwilę, ale na nic nie licz". W tym kontekście, coraz częstszą tendencją kontaktów międzyludzkich zdaje się być wejście w interakcje nie tyle z całą osobą, ile z pełnioną przez nią dla nas rolą - partnera seksualnego „na jedną noc”, który po intymnym zbliżeniu jest wymieniany na „nowszy model”. Widoczny w tekstach Taco Hemingwaya seksualny konsument wydaje się być zainteresowany zaspokojeniem tylko osobistych pragnien' ${ }^{32}$. Postrzega tym samym siebie jako „przedsiębiorstwo rozkoszy i zaspokojenia”33. Autor opisuje ten typ osoby dosyć dosadnie, w następujący sposób wypowiadając się o byłym kochanku swojej ex dziewczyny:

Panie szybki orgazm, uważaj, bo strzelam („Wszystko jedno”).

Zarysowany tutaj sposób podejścia przypomina zmianę zasad rządzących życiem płciowym w zachodnich społeczeństwach. Jak zauważa Davis ${ }^{34}$ :

- głównym jego celem staje się zaspokajanie potrzeb seksualnych, a nie skupianie się na potomstwie;

- relacje intymne stawiają na pierwszym planie jednostkę, a nie grupę (rodzinę);

- interakcje seksualne podlegają indywidualnym ekspresjom: zniesieniu ulegają represje krępujące życie płciowe;

${ }^{30}$ Z. Bauman, Razem osobno, Wydawnictwo Literackie, Kraków 2007, s. 182.

31 Z. Melosik, dz. cyt., s. 73.

${ }^{32}$ Wiek kłamstwa, J. Żakowski rozmawia z prof. Z. Baumanem, [w:] Niezbędnik inteligenta, „Polityka”, 11.12.2004, nr 50.

${ }^{33}$ A. Frindt, Czy warto być dorostym? Społeczno-kulturowe uwarunkowania pojęcia dorosłości w świadomości młodzieży wielkomiejskiej, Wydawnictwo Akademickie „Żak”, Warszawa 2005, s. 92.

${ }^{34}$ J. Davis, Sex These Days, Sex Those Days, ESSAYS ON Theology, Sexuality and Society, Sheffield Academic Press, Sheffield 1997, s. 46, [za:] T. Szlendak, Supermarketyzacja. Religia i obyczaje seksualne młodzieży w kulturze konsumpcyjnej, Wydawnictwo Uniwersytetu Wrocławskiego, Wrocław 2004. 
- otwarty rynek seksualny zastępuje tradycyjny system legitymizowania tego typu relacji.

W tekstach Taco Hemingwaya, millenials to osoba tęskniąca za byciem pożądanym. Musi podziwiać i być podziwianym, uwodzić i być uwodzonym, uczestniczyć, żyć w stanie euforii, nieustannie działać ${ }^{35}$. Ekscytujące seksualnie przygody stają się elementem stylu życia reprezentantów tej grupy. Autor opisuje to następująco:

Puszcza Jolene a potem pije porto do dna. Wpadł w ciąg i nie wiadomo dokąd pogna. Tyle uciech. Całą duszę on tym hordom oddał. Chciał uciec, ale w końcu się tym Polkom poddał („A mówiłem Ci”).

Inna forma konsumpcjonizmu millenialsów związana jest z posiadanymi przedmiotami. Tendencję tę ilustruje wers piosenki „Szlugi i Kalafiory”, ukazujący „miejską wędrówkę" odbywaną w nieodłącznym towarzystwie gadżetów:

Miasto betonu i pogubionych telefonów. Idę ścieżką usłaną szklanym szronem iPhoneów.

Marki są kluczowym elementem egzystencji millenialsów. Jak zauważa A. Gumowska, są one wybierane zgodnie z przekonaniem, że: „Każdy musi być najlepszy, każdy widoczny"36:

Palę mentole fajki, zieleń paczki tej podkreśla moje zielone najki („Szlugi i Kalafiory").

Istotna tutaj staje się pieczołowita dbałość o odpowiedni wizerunek. Autor podkreśla to komentując własne wybory konsumpcyjne, uzależnione jednak od posiadanych finansów:

Jak początek miesiąca to Grolsche, koniec miesiąca to Łomże („6 zer”).

W opisie tego tekściarza życie prowadzone przez jego rówieśników wypełniają akty „konsumpcji na pokaz”:

W mieście dziewczyn, które noszą Nike’i Roshe za dnia. W nocy szpile, dwie tequile, potem no sé hablar ${ }^{37}(„+4822 ”)$.

Konsumowanie wyznacza status jednostki, zatem dobór konkretnych produktów nie jest przypadkowy. Z tego wynikają decyzje dotyczące kupna dóbr „widzialnych”, eksponowanych w przestrzeni publicznej ${ }^{38}$. Posiadanie pewnych gadżetów podnosi wartość millenialsa w oczach „społecznej publiczności”, co niekoniecznie musi być zgodne z rzeczywistym stanem jego finansów:

Rozbity iPhone 6, choć zarabia marne grosze („6 zer”).

${ }^{35}$ A. Frindt, dz. cyt., s. 92.

${ }^{36}$ A. Gumowska, Pokolenie Millenium, http://www.newsweek.pl/polska/pokolenie-milenium,104698,1,1.html (dostęp: 2.01.2018).

37 Tłum. „Nie mogę mówić”.

${ }^{38}$ T. Szlendak, Supermarketyzacja, dz. cyt., s. 86. 
Młodzi ludzie ekscytują się również popularnymi „modami”, wśród których prym wiedzie dbałość o zdrowie. W analizowanych piosenkach („Białkoholicy”, „Awizo”), autor potraktował ten temat $\mathrm{z}$ ironią, wyliczając „fit przykazania” jakimi „bombardowani” są współcześnie żyjący ludzie:

Tego tu nie tykaj, bo zawiera glutaminian! Tu masz tluszcze nasycone. Ile gram? Chyba, ku*wa, z miliard! Tu masz świeży cząber, tu bazylia. Tylko sprawdź czy niepryskane i pamiętaj: GMO zabija. [...] trening rozpoczynaj zawsze od stretchingu. Potem cardio. Kilka kilometrów biegingu. [...] Zapomnij o tych węglowodanach. I unikaj czerwonego jeśli mięso masz w planach. Jeśli woda, tylko mineralna niegazowana. A jak pieczywo to ciemniejsze niż prezydent Obama.

Bycie „fit” jest współcześnie nie tylko promowanym medialnie sposobem „przeżycia", ale i ochroną dla ponowoczesnych lęków. Podejmowanie zdrowego trybu życia to także wyraz proekologicznego, choć niekoniecznie refleksyjnego nastawienia przedstawicieli pokolenia Y. Autor podkreśla ten fakt cytując rady płynące od „fit Mentorów":

Słuchaj, ziomek, nie chcę żadnej wymówki. Jeśli robisz omlet kupuj tylko jajka zerówki. Sprawdź czy kury miały wolny czas na fajne wędrówki. Wołowina? Czy przed śmiercią życie bajką dla krówki?

Taco Hemingway podkreśla, iż osoby podążające za modą na zdrowe odżywianie uznają się za „lepsze” od tych, którzy nie podporządkowują się regułom Nowej Ewangelii Zdrowia ${ }^{39}$ :

Ty jadłeś byle co a widać że apetyt ci urółł. Podczas gdy jadłeś kanapki, szynkę, majonez babuni. Ja jadłem jarmuż i bataty i prażone halloumi.

Idąc dalej, tekst piosenki „Białkoholicy” wydaje się wyszydzać prozdrowotne nastawienia „wyznawców” Nowej Ewangelii Zdrowia, którzy z jednej strony zdrowo się odżywiają, ćwiczą na siłowni, z drugiej zaś nadużywają środków odurzających:

Białkoholików ja tu stale widzę, co węszą biel jak Scooby Doo węszy tajemnice. Potem węszą koks w kiblach. Ile w kokainie błonnika? Uhm... zera gram.

Warto zauważyć, że mimo prześmiewczego stosunku do tzw. „Białkoholików”, autor tekstów nie ukrywa, że jest podatny na tę modę. Jak zauważa:

Rano zamówię Domino’s, choć miałem dietę mieć inną niż dietę piwną. Od lutego zacznę ćwiczyć na stałe („6 zer”).

Idąc tym tropem, w innym fragmencie autor wymienia atrybuty zdrowej diety, budujące jego zbliżoną do boskiej tożsamość:

[...] kupiłem drogie chorizo. Jakieś żytnie pieczywo. Chleby ciemne jak Akon.

Władam sojowym mlekiem, bo jestem soja Posejdon („Awizo”).

${ }^{39}$ Zob. R.W. Dworkin, dz. cyt. 
Tak, jak we wcześniej cytowanych fragmentach, tożsamość millenialsa wydaje się być budowana przez otaczanie się przedmiotami konsumpcji, których „użytkowanie” daje poczucie mocy i kontroli nad rzeczywistością.

\section{Ambiwalencja millenialsów w tekstach Taco Hemingwaya}

Według Słownika Języka Polskiego ambiwalencja to przeżywanie sprzecznych pragnień, doznawanie przeciwstawnych uczuć; współwystępowanie rozbieżnych elementów w postępowaniu, ocenie itp., a także: dwojakość, dwuwartościowość ${ }^{40}$. Z kolei L. Witkowski ${ }^{41}$ opisując ambiwalencję, wskazuje, że jest to: „cecha strukturalna wskazująca na układ dwubiegunowy, w którym działa mechanizm (zasada) oscylacji, wskazanie na niejednoznaczność, dwustronność, [...] ambiwalencja uwypukla dynamikę wewnętrznych napięć,charakteryzujących stany, sytuacje i procesy [...]”.

Jedno z najpopularniejszych rozumień ambiwalencji pochodzi z psychologii i oznacza: „stan umysłu osoby, która w określonej sytuacji jest targana sprzecznymi uczuciami" ${ }^{42}$. Podobnie ten fakt postrzega Taco Hemingway opisujący życie w kulturze pełnej antynomii, wymagającej ciągłej gotowości do zmian. Autor tekstów wydaje się także apelować do swoich słuchaczy, aby porzucili wyidealizowany sposób widzenia rzeczywistości:

[...] życie to nie Ale Kino. Smak naszego życia to wygazowane piwo. Nasze romanse ustępują wszystkim harlequinom. Zamiast czarnej limuzyny zbity pysk, duże czarne limo. Nie szukaj Scarlett, jak nie jesteś Rudolph Valentino. To jest Polska, tutaj stale zimno. Ten kabriolet chowaj, ziomki momentalnie gwizdną („6 Zer”).

W tekstach cytowanego autora ujawnia się nie tylko zwątpienie ale często rezygnacja i poczucie przegranej. Jak zauważa w jednej z piosenek cytowany wykonawca:

Mam dwadzieścia parę lat, moje plany giną („6 zer”).

Tego typu negatywistyczne podejście widoczne jest także w innych tekstach. Egzystencja millenialsów postrzegana bywa tu jako pozbawiona „istotnych momentów”, co autor podsumowuje następująco:

Życie to stek bzdur („Mięso”).

Podobne, negatywne reakcje emocjonalne generuje bolesny fakt „zderzenia $z$ dorosłością”, która przedstawiana jest przez Taco Hemingwaya jako rodząca poczucie zawodu i chęć ucieczki od rzeczywistości:

${ }^{40}$ Hasło „ambiwalencja”, https://sjp.pl/ambiwalencja (dostęp: 16.02.2018).

${ }^{41}$ L. Witkowski, Przełom dwoistości w pedagogice polskiej. Historia. Teoria. Krytyka, Oficyna Wydawnicza Impuls, Kraków 2013, s. 159.

${ }^{42}$ N. Sillamy, Słownik psychologii, Książnica, bmw, 1994, s. 8. 
To jest dorosłość, chciałaś jej od podstawówki, co? Wolę Zozole. Olej to i mnie puknij, no chodź („Trójkąt”).

Otaczająca Taco Hemingwaya rzeczywistość wydaje się być często źródłem rozczarowania. W tekstach obserwujemy również manifestowane przez autora poczucie zazdrości o osoby, które znajdują się w lepszym niż on położeniu:

Wszyscy szczęśliwi ludzie: proszę przestać mnie wkrwiać, bo wszystkim szczęśliwym ludziom planuję dzisiaj coś urwać („Mięso”).

Egzystencja jest widziana przez autora jako łącząca ze sobą "małe szczęścia” i cierpienia. Te ostatnie bywają wiązane przez niego z problemami finansowymi:

Życie to: Bieg przez kosmos. Trochę łez, czasem rozkosz. Potem: lepka pajęczyna w pustym portfelu („Mięso”).

Ambiwalentne nastawienie Filipa Szcześniaka przenosi się również na kwestie religijne. $Z$ jednej strony autor opisuje siebie jako osobę niewierzącą, $\mathrm{z}$ drugiej - w trudnych momentach szuka pomocy Stwórcy:

Jestem ateistą, ale niech mi dobry pan pomoże („6 zer”).

W analizowanych tekstach pojawia się także obecna u Taco Hemingwaya tęsknota za rytuałami religijnymi, które mogłyby nieść pociechę w trudnych momentach życia. Jak zauważa, komentując jedną z sytuacji:

Jakbym był religijny, to bym poszedł na spowiedź. Ale mam kłopoty z Bogiem, myślę widząc Słodowiec („Następna Stacja”).

Ten typ ujęcia zgodny jest z postępującą dziś sekularyzacją. Współczesny człowiek często odchodzi od sfery świętości ucieleśnianej przez instytucje proponujące metafizyczne koncepcje człowieka. Jak wskazuje H. Mamzer, dla współczesnego człowieka konsumowanie staje się często udziałem w sacrum: „miejsca sprzyjające konsumpcji to dziś nowe »kościoły«, a konsumenckie nawyki i zwyczaje zastępują interakcje kształtowane przez tradycyjne religie" ${ }^{43}$.

\section{Millenialsi jako e-generacja w tekstach Taco Hemingwaya}

Cyfrowi tubylcy to generacja, dla której Internet jest naturalnym systemem społecznego komunikowania, pracy i zabawy. Opisując ich, M. Prensky ${ }^{44}$ wskazuje, że są oni niecierpliwi, przyzwyczajeni do szybkiej wymiany informacji, preferują wielozadaniowość i multitasking. Ten aspekt bez wątpienia oddziałuje na tworzone relacje.

${ }^{43}$ H. Mamzer, Baranek na talerzu. Ponowoczesne meandry konsumpcji, [w:] J. Grad, H. Mamzer (red.), Kultura przyjemności. Rozważania kulturoznawcze, Wydawnictwo Naukowe Uniwersytetu Adama Mickiewicza, Poznań 2005, s. 27.

${ }^{44}$ M. Wilkowski, Cyfrowi tubylcy i ich społeczny potencjat, https://edunews.pl/badania-i-debaty/badania/1095-cyfrowi-tubylcy-i-ich-spoleczny-potencjal (dostęp: 1.03.2018). 
Spotkania zastępowane są dziś często przez wysłanie SMS-a, emotikonek w postaci buziaka „:*”, czy serduszka „<3”. Z kolei kliknięcie „lubię to” na Facebooku okazuje się być prostym miernikiem zainteresowania drugą osobą. Ten fakt gorzko komentuje sam autor:

[...] teraz wiem już czemu on ci dawał te lajki („Szlugi i Kalafiory”).

Warto zauważyć, że millenialsi szybko wychwytują zasady funkcjonujące w świecie mediów, m.in. bycie w stałym kontakcie z innymi (co pozwala „czuć się pewnie” i mieć dostęp do „świata innych użytkowników”). Utrata połączenia generować może napady paniki (FOMO). W odniesieniu do tekstów, znajduje to odzwierciedlenie w rozpaczliwych „apelach” autora, będącego w takiej, jak tutaj opisywana, sytuacji:

Odpisz bo będę tu płakał do rana („900729”).

Należy zauważyć, że w e-rzeczywistości obowiązują inne reguły niż w świecie starszego pokolenia, pozwalające m.in. na ignorowanie zasady ciszy nocnej:

Dzwonię tak do ciebie o czwartej nad ranem. Na dworze zimowe deszcze więc jestem raczej zalany („900729”).

Millenialsów określić można jako pokolenie Facebooka i Instagrama (za: Raport Fluentco, Marketing to Millenials 2016 ${ }^{45}$ ). Posiadanie profilu przynajmniej w jednym z tych portali jest dzisiaj koniecznością, brak takiej partycypacji bywa tożsame z fizycznym nieistnieniem ${ }^{46}$. W social mediach można znaleźć informacje na temat innych: tego, co ktoś lubi, „jaki jest”, gdzie aktualnie przebywa. Tę cechę wskazuje również Taco Hemingway:

Widzę na Insta, że ty też gdzieś jesteś („Przerywnik”).

Social media pozwalają na kreowanie atrakcyjnego wizualnie wizerunku. Jak zauważa w piosence „Białkoholicy” autor:

Na Facebooku same sześciopaki.

Warto tu jednak zauważyć, że to, co podawane jest do publicznej wiadomości, często nie ma zbyt wiele wspólnego z prawdą:

Ludzie raczej słabi są, ja to słabo znoszę. Czarne dziury się podają za poranne zorze („6 zer”).

Według Melosika, wskutek „zanurzenia” w obecnym stanie kulturowym, w ludziach powstaje nawyk „klikania” w rzeczywistość, możliwy dzięki temu staje się także proces swobodnego przemieszczania się przez różnorodne doświadczenia i gadże-

${ }^{45}$ Por. http://www.fluentco.com (dostęp: 1.03.2018).

${ }^{46}$ Popularnym stwierdzeniem używanym przez młodych ludzi jest: „Nie ma w Google, nie ma w ogóle” lub „Nie ma Cię na fejsie - nie istniejesz” - co jest równoznaczne z presją zostawienia po sobie „śladu” w cyberprzestrzeni. 
ty kulturowe ${ }^{47}$. Aspekt ten jest zauważany także przez autora analizowanych piosenek, który następująco określa oczekiwania własnych fanów:

Ludzie by chcieli tu lepszej techniki. Przyspieszeń, hashtagów i więcej impetu („Od zera”).

W piosence „Białkoholicy” autor porównuje z kolei zachowanie ludzi do właściwości plików komputerowych:

Połowa ludzi to GIF’y, w kółko powtarza swe błędy. Druga połowa stoi w miejscu, to kraj JPG’ów („Białkoholicy”).

GIFy imitują zatem ciągłe powtarzanie nieefektywnych czynności, zaś JPG jest metaforą równie surowo przez Taco Hemingwaya ocenianej stagnacji życiowej. Wybierając którąkolwiek z tych „opcji życiowych” egzystujemy tylko pozornie, co może przywoływać na myśl mechaniczne podejmowanie różnorodnych działań lub przeciwnie - trwanie w stanie apatii i depresji.

\section{Millenialsi - „poszukiwacze wrażeń” w tekstach Taco Hemingwaya}

Najczęściej przywoływaną w psychologii definicją otwartości na doświadczenia jest konstrukt P.T. Costy i R.R. McCrae ${ }^{48}$ ujęty w pięcioczynnikowym modelu osobowości. Otwartość na doświadczenia to wewnętrzna, względnie stała i ogólna dyspozycja do zachowywania się w sprecyzowany sposób. Cecha definiowana jest jako skłonność do pozytywnego wartościowania i poszukiwania doświadczeń, ciekawość poznawcza i tolerancja na nowość ${ }^{49}$. Otwartość na nowe doznania jest mocno widoczna w analizowanych tekstach. Najczęstszymi doświadczeniami millenialsów są opisane wcześniej promiskuitywne związki, dostarczające ekscytujących doznań ${ }^{50}$. Poszukiwaniu doświadczeń równie często wydają się towarzyszyć jednak środki odurzające. Opis ich konsumpcji bliższy jest w analizowanych tekstach nadużywaniu niż „eksperymentowaniu”:

Najpierw - narkotyki, potem - czar muzyki. Butlę porto chwycił i jedną czwartą wypił („Wszystko jedno”).

Spotkania millenialsów są często „zakrapiane” alkoholem. Napoje wyskokowe (co podkreśla sam autor), to znaczący element wielu „eventów”:

${ }^{47}$ Z. Melosik, dz. cyt.

${ }^{48}$ P.T. Costa, R.R. McCrae, Osobowość dorosłego człowieka: perspektywa teorii pięcioczynnikowej, Wydawnictwo WAM, Kraków 2005.

${ }_{49}$ B. Zawadzki, J. Strelau, P. Szczepaniak, M. Śliwińska, Inwentarz osobowości NEO-FFI Costy i McCrae adaptacja polska: podręcznik, Pracownia Testów Psychologicznych PTP, Warszawa 1998.

${ }^{50}$ Tamże, s. 82. 
Czysta wóda pita w brudnych palarniach (....) Raz dwa. Tu kieliszek, chlup! Dla kurażu („+4822”).

Ten opis zgodny jest z pojawiającymi się doniesieniami o alkoholizowaniu się jako nieodłącznym aspekcie stylu millenialsów. Warto zauważyć, że według badań organizacji Wine Market Council reprezentanci tej grupy piją najwięcej alkoholu spośród innych generacji ${ }^{51}$ : wydaje się, że reprezentanci tej grupy sięgają po używki nie tylko w celach rozrywkowych, ale również po to, by dodać „elementu baśniowego” do nie zawsze pozytywnie przeżywanej przez nich rzeczywistości:

Wczoraj demony, chyba piłem z nimi kielich. Błagały, żebym dzielił się z nimi („Następna Stacja”).

Młodzi ludzie przyzwyczajeni są do „wideoklipowego” tempa narracji, skrótowości i zmienności ${ }^{52}$. Poszukiwanie wrażeń wydaje się wychodzić naprzeciw przyspieszającej rzeczywistości. Każdego dnia pojawiają się i znikają nowe trendy, idee i zjawiska. Istotne staje się „uczestnictwo w życiu”, oznaczające „bywanie” w modnych miejscach. Jak zauważa T. Szlendak, o statusie społecznym w społeczeństwie konsumpcyjnym decyduje właśnie rodzaj zabawy i spędzania wolnego czasu ${ }^{53}$. Ten sposób funkcjonowania w rzeczywistości wydaje się być oczywistością życia millenialsów, co podkreśla sam autor:

Jestem tu, byłem tam, zresztą w sumie kto nie był („Marsz, marsz”).

A także:

Ach, te klubokawiarnie. Wskazać mi je to jak pokazywać kuwom latarnie $(,+4822 ”)$.

Tendencja ta może być wiązana ze zjawiskiem karnawalizacji codzienności, „czynieniem fiesty z banalnych czynności" ${ }^{54}$. Ilustracją tego cytatu wydaje się być fragment ukazujący wyobrażenie idealnego związku, następująco postrzeganego przez autora:

Chcę z tobą chadzać po knajpach, zamawiać kus-kus na spółę. Potem w nocy się kochać i rano zamawiać pizzę („Marsz, marsz”).

Jak wynika z analizowanych tekstów, swoistym „celem samym w sobie” staje się wizytowanie miejsc, w których toczy się, w rozumieniu „millenialsów”, „prawdziwe życie":

[...] obok w Zakąskach za barem się pląsa Pan Roman i wtrąca w rozmowy się.

A obok w Kamieniach, małżonków wciąż nie ma więc całują słomiane wdowy

${ }^{51}$ Por. http://natemat.pl/193101,zadne-pokolenie-nie-pilo-tyle-alkoholu-co-millenialsi-alejest-zmiana-pija-nie-piwo-i-nie-wodke-a-najczesciej-wino, https://www.forbes.pl/przywodztwo/ pokolenie-y-i-z-milenialsi-na-zakupach/czrxqxc (dostęp: 1.03.2018).

${ }_{52}$ Z. Melosik, dz. cyt., s. 74.

${ }^{53}$ T. Szlendak, Supermarketyzacja, dz. cyt., s. 66.

${ }^{54}$ Tamże, s. 147. 
się. A obok, tam w Bistro, miłości na szybko się wiążą i milkną gdy nowy dzień („Trójkąt”).

Podobna predylekcja uwidacznia się również we fragmencie utworu „Wszystko jedno", gdzie autor kreśli opowieść o żądnych przygód młodych studentkach:

Wybrały się do klubu, z koleżankami z UW. Wzięły po parę buchów i oczekują cudów. Oczekiwały cudów, nie spodziewały się brudu. Chciały przebojów, ale słyszą tylko łubu-dubu („Wszystko jedno”).

Zawarty w tekście opis ukazuje oczekiwania millenialsów chcących od rzeczywistości „czegoś więcej”, choć jak się wydaje to „coś” nie zawsze jest przez nich precyzyjnie zdefiniowane i rozpoznane. W życie współczesnego millenialsa „poszukiwacza wrażeń”, wplecione jest także podejmowanie ryzykownych zachowań, które wyraźnie ekscytują głównego bohatera:

Przechodzę na czerwonym, będzie mandat - kozacko. Rano będzie słabo, teraz sram na to („Trójkąt”).

Podobne wrażenie można odnieść po innym fragmencie, w którym Taco Hemingway zauważa:

Ktoś mnie pyta z kim tu jestem. Ktoś inny mnie pyta czy chcę w pysk. Mówię: „bardzo proszę”. Wyrastają guzy, niby Karkonosze („6 zer”).

Tego typu incydenty wydają się nadawać życiu millenialsów specyficznego kolorytu. Na pierwszy plan wysuwane jest „życie chwilą”, gromadzenie nawet negatywnych doświadczeń:

Mój przyjaciel skończył skacowany w izbie wytrzeźwień. Z menelami. Każdy z nich wyglądał jak Leonid Iljicz Breżniew („+4822”).

Tego rodzaju wypadki nie wydają się być czymś zniechęcającym do pijackich eskapad, ale elementem „barwnego życiorysu”, będącego tematem anegdot towarzyskich. Ważne wszak, „żeby coś się działo”.

Jak wynika z analizy tekstów Taco Hemingwaya, przedstawicielom pokolenia millenium towarzyszy powrót do sfery życia codziennego. Obrazuje to rytm ich egzystencji, wyznaczany przez powtarzające się wydarzenia, czasem niezwykłe, częściej boleśnie zwyczajne. Narrator, niczym bohater powieści Jamesa Joyce’a, przeżywa życie znaczone pobytem w klubach, korzystaniem z używek i erotycznymi przygodami. Tendencję tę ukazuje tekst utworu „Następna Stacja”, w którym autor barwnie opisuje mieszkańców Warszawy spotykanych na kolejnych przystankach metra. 


\section{Millenialsi jako prekariusze ${ }^{55} \mathbf{w}$ tekstach Taco Hemingwaya}

Pojęcie „prekariat” stanowi złożenie dwóch angielskich terminów: precarious niepewność i proletariat - biedna klasa pracująca ${ }^{56}$. W literaturze przedmiotu można odnaleźć wiele definicji tego pojęcia, w większości z nich można wyróżnić atrybuty wspólne, do których należą: funkcjonowanie w systemie kapitalistycznym, brak stabilności, wykluczenie z powszechnego systemu zabezpieczenia społecznego oraz odwoływanie się do przyszłej niepewnej sytuacji jednostki ${ }^{57}$. Choć pojęcie „prekariatu” nie powinno być kojarzone tylko z osobami ubogimi, bezrobotnymi czy pracującymi na umowy czasowe, właśnie ten aspekt bywa najbardziej widoczny.

Jak można zauważyć w analizowanych tekstach, istotną częścią życia millenialsów jest pełnienie roli zawodowej. Autor opisuje własnych kolegów: zorientowanych na sukces, ambitnych i przedsiębiorczych, „biorących sprawy we własne ręce”. Autor przedstawia siebie w kontraście do tego opisu:

Moi znajomi robią biznes a ja wciąż jestem nikim. Cywilizują się nagminnie, a ja wciąż jestem dziki. Do szafy schowali vansy, powoli noszą trzewiki i poważnieją, nazywają nagle „moczem” swe siki („900729”).

W treści innej z piosenek odzwierciedla się także bunt autora przed „formalnie” określonym postrzeganiem własnej osoby. Autor manifestuje ten sprzeciw, odnosząc się do ważnych określników tożsamości:

NIP-y, PIN-y, PESEL-e, ja wcale nie jestem liczbą („Awizo”).

Z analizy utworów Taco Hemingwaya wynika, że pokolenie millenialsów to konsumenci o możliwościach prekariuszy, borykający się z nieustannymi problemami finansowymi:

Wąsaty chłopiec stawia szoty dzisiaj na Brutażu. [...]. Ten młody gangster jest na co dzień na bezpłatnym stażu. Żeby tańczyć z tą piękną co ma cudne dziary musi śpiewać tu z Jagiełłą i Zygmuntem Starym. A na co dzień milczy z Mieszkiem i Chrobrym („+4822”).

W badanych tekstach autor ukazuje również swoją sytuację materialną, niepozwalającą na realizację odległych (ale uświadamianych przez narratora) życiowych planów. Ten fakt komentowany jest następująco:

Nie wiem jak za pieniądz z wierszy mam zbudować rodzinę („100km/h”).

${ }^{55}$ Wykonawca ten, ochrzczony rzecznikiem prekariuszy, sam się jednak od tych politycznych skojarzeń odżegnuje. Zob. https://rozrywka.trojmiasto.pl/Taco-Hemingway-hipsterski-raper-n94784.html; http://natemat.pl/148631,taco-hemingway-odkleja-od-siebie-latke-hiphopowego-trybuna-prekariuszy (dostęp: 8.04.2018).

${ }^{56}$ K. Cymbranowicz, Prekariat - nowe zjawisko na rynku pracy w Polsce, „Annales. Etyka w Życiu Gospodarczym", vol. 19, nr 2, maj 2016, s. 17-30, 2015, s. 18.

${ }^{57}$ https://www.research-gate.net/publication/260082284 (dostęp: 27.02.2018). 
Z drugiej strony, w tekstach uwidacznia się również brak przedsiębiorczości Taco Hemingwaya, który przyznaje, że nierzadko sam nieracjonalnie zarządza pieniędzmi:

Mógłbym nie wydawać forsy, ale płakać wolę, [...] Jeden koma trzy koła dla fiskusa w tym roku. Gdzie są moje hajsy? Jestem młody Korwin w amoku („Awizo”).

Nieroztropnemu rozporządzaniu finansami towarzyszy uleganie współczesnym modom, także uprzednio wyszydzanym przez autora „trendom dietetycznym”. Konfrontując się z tym faktem, autor stwierdza:

Znowu nie mam na życie, wszystko wydałem na humus. [...] Ja jadłem jarmuż i bataty i prażone halloumi. Malinowe pomidory leżą dwa na stole. Mógłbym mniej wydawać forsy, ale płakać wolę. Jakieś pół wypłaty poszło mi na guacamole. Bo w Piotrze \& Pawle cztery awokado dwa patole („Awizo”).

Katastrofalna sytuacja finansowa autora wiąże się nie tylko jego niezaradnością, ale i manifestowanym przez niego oporem wobec słuchania rad starszego pokolenia:

Miałem tróję z podstaw przedsiębiorczości. „Nie wydawaj, żyj oszczędnie” ciągle szepcą dorośli („Awizo”).

Ekspresja „Ja” millenialsów wydaje się objawiać w dwojaki sposób. Z jednej strony młodzi ludzie starają się być niezależni, samodzielni, patrzący w przyszłość. Z drugiej zaś, pewna część pokolenia to osoby korzystające z pomocy finansowej rodziców. Aspekt tej specyficznej „opieki” staje się wyraźnie widoczny w tekstach autora:

Mama pyta czy chcę jakiś przelew. Mówię: „bardzo proszę” („6 zer”).

Z drugiej strony, z analizowanych tekstów wynika, że autor dostrzega rolę własnej inicjatywy w realizacji zakładanych celów, w pewnym sensie zakładając, że odpowiedzialność za porażkę spoczywa przede wszystkim na jego barkach ${ }^{58}$.

Kowal swego losu, boskich Hefajstosów nie winię i nie zamierzam czekać aż tu każdy oszust przeminie („100km/h”).

W innym fragmencie Taco Hemingway zauważa z kolei:

Muszę coś zbudować od zera, bo już nie mogę polegać na tych „umowach o dzieła” („Od zera”).

Przyjęte tu postanowienie odnosić może się do podjęcia bardziej „dorosłych”, zobowiązujących i odpowiedzialnych działań, dotyczących nie tylko pracy zawodowej, ale i innych sfer życia jednostki.

${ }^{58}$ Por. T. Szlendak, Supermarketyzacja, dz. cyt., s. 14-15. 


\section{Podsumowanie}

Wyodrębnione w trakcie analizy kategorie odnoszące się do postrzegania millenialsów jako: konsumentów, osób zawieszonych między sceptycyzmem a (wciąż) młodzieńczym idealizmem, „cyfrowych tubylców”, „poszukiwaczy wrażeń” i prekariuszy umożliwiły stworzenie specyficznego portretu pokoleniowego. $\mathrm{Z}$ analizowanych tekstów wyłania się obraz tej grupy postrzeganej w dużej mierze jako baumanowskich „kolekcjonerów doznań”, których rytm życia wyznaczają przelotne związki, podróże metrem i „hedonistyczne spacery” po klubokawiarniach. Teksty Hemingwaya uwidaczniają jednak często również bolesne „zderzenia” potencjalnych możliwości z rzeczywistością trosk finansowych, pracy tymczasowej, a przede wszystkim - samotności przeżywanej „w tłumie”. Z jednej strony, z analizy tekstów wyłania się opis dość powierzchownych problemów millenialsów ironicznie komentowanych przez samego autora, znajdującego się „wewnątrz” i na „zewnątrz” opisywanych historii. Z drugiej, często wyrażane są tam głębokie trudności reprezentantów pokolenia millenium, nie potrafiących radzić sobie z poszczególnymi aspektami egzystencji. „To, o czym rymują młodzi artyści, dotyczy tego, jak funkcjonują w społeczności, perspektyw na przyszłość lub ich braku. Poprzez analizę przekazów płynących z tych tekstów powinniśmy zwrócić uwagę na problemy społeczne, z jakimi przychodzi się im skonfrontować" 59 .

Jaka zatem „odpowiedź zwrotna” dana społeczeństwu wyłania się z analizy piosenek Taco Hemingwaya? Czy powinniśmy zapamiętać z niej obraz millenialsów, „poszukiwaczy doznań”, którym inni są potrzebni głównie do zaspokajania ich własnych potrzeb i tworzenia pozornie wspólnotowej „sieciowej towarzyskości”? A może ważniejsze staje się dostrzeżenie głębszej warstwy analizy, z której wyodrębnia się obraz bezsilnych i niekoniecznie umiejących odnaleźć się w przyspieszającym świecie młodych ludzi? Poza wskazanymi tu zagadnieniami, warto zauważyć również, że przedstawiony w tym artykule problem rodzić może określone implikacje pedagogiczne. W odniesieniu do ujętej w tym tekście analizy znaczące może stać się zasygnalizowanie pewnych obszarów naukowej refleksji. Może być ona rozwijana na gruncie m.in.:

- pedagogiki pracy - co dotyczy namysłu nad prekaryjną często pozycją młodych osób na współczesnym rynku pracy, a także przystosowania warunków realizacji ich roli zawodowej do potrzeb, oczekiwań i specyficznych charakterystyk przedstawicieli tego pokolenia;

- pedagogiki rodziny - co odnosi się do podjęcia namysłu nad przyczynami i konsekwencjami charakteru bliskich relacji podejmowanych przez millenialsów, analizy przejawów i uwarunkowań ich funkcjonowania w stanie nieustan-

${ }^{59}$ M. Kozłowska, Ideologia hip-hopowa na przykładzie tekstów hip-hopowych, „Kultura. Społeczeństwo. Edukacja”, nr 2/2012, s. 131, https://repozytorium.amu.edu.pl/bitstream/10593/7683/1/ KSE2 str 119-133.pdf (dostęp: 13.02.2018). 
nego zanurzenia w wirtualnym świecie (co nierzadko urealnia realizację przez nich bliskich związków interpersonalnych);

- dydaktyki akademickiej - co może dotyczyć np. aspektu planowania i realizacji edukacji w szkołach wyższych przez reprezentantów grupy digital natives.

Wymienione obszary stanowią, rzecz jasna, tylko wybrane aspekty, które powinny zostać poddane dalszym, pogłębionym analizom. Uwzględnienie ich może stać się ważnym elementem namysłu dotyczącego sytuacji młodych dorosłych, znaczącego ze względu na fakt postrzegania ich jako ważnych podmiotów oddziałujących na dynamicznie przebiegające procesy społeczne.

\section{Bibliografia}

Bauman Z., Konsumowanie życia, Wydawnictwo Uniwersytetu Jagiellońskiego, Kraków 2009.

Bauman Z., Razem osobno, Wydawnictwo Literackie, Kraków 2007.

Bendyk E., Zęby w bawełnie, [w:] Niezbędnik inteligenta, „Polityka”, 16.12.2006, nr 50.

Costa P.T., McCrae R.R., Osobowość dorosłego człowieka: perspektywa teorii pięcioczynnikowej, Wydawnictwo WAM, Kraków 2005.

Cymbranowicz K., Prekariat - nowe zjawisko na rynku pracy w Polsce, „Annales. Etyka w Życiu Gospodarczym”, vol. 19, nr 2, maj 2016, 17-30, 2015.

Davis J., Sex These Days, Sex Those Days, ESSAYS ON Theology, Sexuality and Society, Sheffield Academic Press, Sheffield 1997.

Denzin N.K., Lincoln Y.S., (red.), Metody badań jakościowych, t. 1, Wydawnictwo Naukowe PWN, Warszawa 2009.

Dworkin R.W., Nowa ewangelia zdrowia, [w:] P. Sztompka, M. Bogunia-Borowska, Socjologia codzienności, Wydawnictwo Znak, Kraków 2008.

Dziopak-Strach A., Pokolenie Y wyzwaniem dla działów HR, ZN WSH „Zarządzanie”, nr 2/2016.

FDU Magazine, Mixing and Managing Four Generations of Employees, http://www. fdu.edu/newspubs/magazine/05ws/generations.htm (dostęp: 20.02.2018).

Frindt A., Czy warto być dorosłym? Społeczno-kulturowe uwarunkowania pojęcia dorosłości w świadomości młodzieży wielkomiejskiej, Wydawnictwo Akademickie „Żak”, Warszawa 2005.

Gruszka A., Cyfrowi tubylcy wchodza do gry, http://marketing.org.pl/archiwum/index.php/go=2/act=2/aid $=$ m55c13eb5cfae3 (dostęp: 5.03.2018).

Gumowska A., Pokolenia Millenium, „Newsweek”, http://www.newsweek.pl/polska/ pokolenie-milenium, 104698,1,1.html (dostęp: 2.01.2018).

Hasło „ambiwalencja”, https://sjp.pl/ambiwalencja (dostęp: 15.03.2018). 
Jawłowska A., Miejsce Wartości wświecie reklamy, [w:] A. Jawłowska-Konstanciak, J. Mariański (red.), Kondycja moralna społeczeństwa polskiego, Wydawnictwo WAM, Kraków 2002.

Karnaszewski P., Władze przejmuja młodzi. Jak kupuje pokolenie $Y i Z$, https://www. forbes.pl/przywodztwo/pokolenie-y-i-z-milenialsi-na-zakupach/czrxqxc (dostęp: 27.02.2018).

Kluz K., Slany K., Kształtowanie systemu wartości jako kierunek działań polityki ludnościowej, [w:] D. Graniewska (red.), Sytuacja rodzin i polityka rodzinna w Polsce, Instytut Praci i Spraw Socjalnych, Warszawa 2003.

Kozłowska M., Ideologia hip-hopowa na przykładzie tekstów hip-hopowych, „Kultura. Społeczeństwo. Edukacja”, nr 2/2012, https://repozytorium.amu.edu.pl/bitstream/10593/7683/1/KSE2 str 119-133.pdf (dostęp: 13.02.2018).

Ławnicki T., Żadne pokolenie nie piło tyle alkoholu, co Millenialsi. Ale jest zmiana: pija nie piwo i nie wódkę, a najczęściej wino, http://natemat.pl/193101,zadne-pokolenie-nie-pilo-tyle-alkoholu-co-millenialsi-ale-jest-zmiana-pija-nie-piwo -i-nie-wodke-a-najczesciej-wino (dostęp: 15.03.2018).

Mamzer H., Baranek na talerzu. Ponowoczesne meandry konsumpcji, [w:] J. Grad, H. Mamzer, Kultura przyjemności. Rozważania kulturoznawcze, Wydawnictwo Uniwersytetu Adama Mickiewicza, Poznań 2005.

Melosik Z., Kultura popularna jako czynnik socjalizacji, [w:] Z. Kwieciński, B. Śliwerski (red.), Pedagogika. Podręcznik akademicki, cz. 2, Wydawnictwo Naukowe PWN, Warszawa 2003.

Niezgoda M., Młodzież. Kłopotliwa kategoria socjologiczna, „Jagiellońskie Studia Socjologiczne", nr 1/2014, http://ejournals.eu/sj/index.php/ISB/article/view/1 (dostęp: 26.02.2018).

Rusek H., Wspótczesne młode pokolenie jako wyzwanie dla socjalizacji i wychowania, [w:] T. Lewowicki, A. Szczurek-Boruta, B. Grabowska (red.), Przemiany społeczno-cywilizacyjne i edukacja szkolna - problemy rozwoju indywidualnego i kształtowania się tożsamości, Oficyna Wydawnicza Impuls, Kraków 2005.

Saldaña, J., The coding manual for qualitative researchers, Sage Publications Ltd, Thousand Oaks 2009.

Sillamy N., Słownik psychologii, tłum. K. Jarosz, Wydawnictwo Książnica, bmw, 1994.

Szlendak T., Leniwe maskotki, rekiny na smyczy, Wydawnictwo Czarna Owca, Warszawa 2005.

Szlendak T., Supermarketyzacja. Religia i obyczaje seksualne młodzieży w kulturze konsumpcyjnej, Wydawnictwo Uniwersytetu Wrocławskiego, Wrocław 2004.

Wernio M., Kogo Polacy stuchali najczęściej w 2017 roku? Dwóch raperów napodium rankingu Spotify, https://noizz.pl/muzyka/spotify-ranking-najczesciej-sluchani-artysci-2017-roku-wedlug-spotify/215mfmz (dostęp: 5.02.2018).

Wilkowski M., Cyfrowi tubylcy i ich społeczny potencjał, https://www.edunews.pl/badania-i-debaty/badania/1095 (dostęp: 1.03.2018). 
Wiek kłamstwa, J. Żakowski rozmawia z prof. Z. Baumanem, [w:] Niezbędnik inteligenta, „Polityka”, 11.12.2004, nr 50.

Witkowski L., Przełom dwoistości w pedagogice polskiej. Historia. Teoria. Krytyka, Oficyna Wydawnicza Impuls, Kraków 2013.

Wrzesień W., Pokoleniowość współczesnej polskiej młodzieży, „Władza Sądzenia”, nr $7 / 2005$.

Zawadzki M., Komunikacja werbalna i niewerbalna subkultury satanistów i metalowców. Podobieństwa i różnice obu grup, [w:] Z. Pasek (red.), Ezoteryzm, okultyzm, satanizm w Polsce, Wydawnictwo Libron, Kraków 2005.

Zawadzki B., Strelau J., Szczepaniak P., Śliwińska M., Inwentarz osobowości NEO-FFI Costy i McCrae: adaptacja polska: podręcznik, Pracownia Testów Psychologicznych PTP, Warszawa 1998.

\section{A Portrait of Polish Millennials in the songs of Taco Hemingway}

Abstract: This article reconstructs the image of Polish Millennials in Taco Hemingway's songs. It makes use of content analysis in an interpretative paradigm, in accordance with the contextual theory of meaning. Songs lyrics included on the mini-albums „Trójkąt warszawski” (2014) and „Umowa o dzieło” (2015) are analysed. The lyrics portray representatives of the Millenium generation as consumers, ambivalent people (on the one hand, very skeptical, on the other hand - idealistic), „digital natives”, ,adventure seekers” and as members of the 'precariat'. Hemingway is referred to as "the voice of a generation that has nothing to say", and an analysis of his songs is an important contribution to debates on Millennials' characteristics, their needs, opinions and views. The article has pedagogical implications and it signals certain areas for research and reflection.

Kaywords: Millenials, portrait, music, Taco Hemingway

About the authors: Katarzyna Smoter (Institute of Pedagogy, Jagiellonian University), graduate of Pedagogy (2008) and Sociology (2011) at the Jagiellonian University, She is $\mathrm{PhD}$ of social science in the field of pedagogy (2016). Areas of academic interest multicultural education, didactics, antidiscrimination education, higher education, popular culture.

Karolina Kołodziejczak (Institute of Pedagogy, Jagiellonian University), a graduate of social care pedagogy (2015), school pedagogy with pedagogical therapy and remedial education (2017) at the Jagiellonian University. She is PhD student of social science in the field of pedagogy. Areas of academic interest: reception of music, active participation in musical culture and its pedagogical implications, radio, school pedagogy. 
Magdalena Sasin* (iD https://orcid.org/0000-0003-4760-0460

Uniwersytet Łódzki

\title{
Kanon wykonawczy muzyki poważnej jako przestrzeń spotkania Innego
}

\begin{abstract}
Streszczenie: Tematem artykułu jest poznawanie i upowszechnianie kultury innych narodów i kręgów cywilizacyjnych na przykładzie muzyki poważnej w kontekście bezpieczeństwa kulturowego. Poczucie bezpieczeństwa kulturowego, trudne do osiągnięcia w zmieniającym się świecie, nie jest możliwe bez otwartości na Innego, które z kolei nie może zaistnieć, gdy brak uznania wartości własnej kultury. Wychodząc z tego założenia, autorka analizuje działalność wybranych orkiestr symfonicznych i festiwali muzyki współczesnej w Polsce i za granicą (w Europie i poza nią). Ten wycinek życia kulturalnego pozwala na dostrzeżenie ciekawych zjawisk, związanych z tradycją, przyzwyczajeniami słuchaczy, społecznymi oczekiwaniami wobec instytucji kultury, różnicami międzykulturowymi. Akt wykonania i percepcji utworu muzycznego jest aktem komunikacyjnym, w sprzyjających okolicznościach umożliwiając zbliżenie się do Innego i poznanie go.
\end{abstract}

Słowa kluczowe: kultura muzyczna, upowszechnianie muzyki, bezpieczeństwo kulturowe

\section{Wprowadzenie}

Dynamiczne przemiany w układzie narodowościowym ludności wielu krajów świata, także krajów europejskich, tworzą nieznane dotąd problemy i generują nowe wyzwania. W tej sytuacji dużego znaczenia nabiera kwestia bezpieczeństwa kulturowego, zarówno obiektywnego - definiowanego jako brak zagrożeń, wynikający z właściwej ochrony dóbr kultury materialnej i duchowej, jak i subiektywnego - określa-

* Magdalena Sasin - dr, adiunkt w Katedrze Edukacji Artystycznej i Pedagogiki Twórczości Wydziału Nauk o Wychowaniu Uniwersytetu Łódzkiego. Zainteresowania naukowe: edukacja estetyczna i artystyczna ze szczególnym uwzględnieniem edukacji muzycznej, edukacja medialna, upowszechnianie sztuki wśród dzieci, młodzieży i dorosłych w instytucjach pozaszkolnych, poprzez media oraz w sytuacjach nieformalnych (rodzina, przyjaźnie, zainteresowania, czas wolny), ekologia akustyczna. 
nego jako poczucie bezpieczeństwa kulturowego i swobody ekspresji1․ Budowaniu i wzmacnianiu obiektywnego poczucia bezpieczeństwa kulturowego służyć powinny głównie działania polityków na szczeblu krajowym i międzynarodowym, natomiast budowanie subiektywnego poczucia bezpieczeństwa kulturowego jest wyzwaniem dla pedagogiki. Szczególnego znaczenia nabiera tutaj edukacja międzykulturowa. Mimo pewnych kontrowersji zwykle uważa się, że wielokulturowość, czyli egzystencja na wspólnym obszarze wspólnot, które cechuje poczucie odrębności narodowej, powinna prowadzić do międzykulturowości, a więc interakcji między tymi kulturami, ich wzajemnego przenikania się i wymiany wartości. Nie jest to możliwe bez intencjonalnego i pełnego otwartości spotkania z Innym - spotkania, które, jak wskazywał kilkanaście lat temu Ryszard Kapuściński, jest jednym z najważniejszych wyzwań ludzkości XXI wieku².

Wzajemnemu zrozumieniu sprzyja jak najlepsze poznanie innych narodów - nie tylko ich gospodarki czy demografii, ale także kultury. Jeden z ojców integracji europejskiej, Jean Monnet, niezadowolony z przebiegu tego procesu, miał powiedzieć, że gdyby zaczynał jeszcze raz, zacząłby od kultury³. Jak podkreśla M. Krycki, kultura:

[...] nie jest już jedynie wewnętrznym czynnikiem identyfikacji społecznej, ale staje się środkiem identyfikacji danego kraju w globalnej świadomości. Tak jak wiek XX wygenerował nową dziedzinę gospodarki - turystykę, [...], tak wiek XXI - przez pojawienie się fenomenu globalizacji i wolnej przestrzeni wymiany idei i wartości - staje się wiekiem kultury ${ }^{4}$.

Wśród zjawisk związanych z kulturą szczególny charakter ma sztuka, uważana przez Bogdana Nawroczyńskiego za najwyższe piętro w układzie hierarchicznym kultury, gdyż zarówno jej wytwory, jak i czynności ją konstytuujące są aksjotwórcze ${ }^{5}$. Tworzenie i percepcja sztuki mogą być postrzegane jako szczególny przykład procesu komunikowania się - przekazywania informacji, poglądów, emocji i sposobu postrzegania świata między twórcą a odbiorcą oraz w gronie odbiorców między sobą. Komunikacyjna funkcja sztuki uważana jest za jedną z najistotniejszych 6 . W odnie-

${ }^{1}$ J. Czaja, Bezpieczeństwo kulturowe. Zarys problematyki, Krakowska Szkoła Wyższa im. Andrzeja Frycza Modrzewskiego, Kraków 2004.

2 R. Kapuściński, Spotkanie z Innym - jako wyzwanie XXI wieku, „Gazeta Wyborcza”, 1.10.2004, http://wyborcza.pl/1,76842,2318704.html (dostęp: 28.04.2018).

${ }^{3}$ K. Krzysztofek, Zbliżanie się Polski do Unii Europejskiej - aspekt kulturowy, cyt. za: M. Krycki, Komunikowanie międzynarodowe i komunikowanie międzykulturowe, [w:] R. Zenderowski, K. Cebul, M. Krycki (red.), Międzynarodowe stosunki kulturalne, Wydawnictwo Naukowe PWN, Warszawa 2010 , s. 379.

${ }^{4}$ M. Krycki, dz. cyt., s. 393.

${ }^{5}$ M. Zalewska-Pawlak, Rola sztuki w wychowaniu. Polska tradycja pedagogiczna, Wydawnictwo Uniwersytetu Łódzkiego, Łódź 2001.

${ }^{6}$ M. Golka, Socjologiczny obraz sztuki, ars nova, Poznań 1996. 
sieniu do muzyki na jej walor komunikacyjny wskazują m.in. M. Dymon ${ }^{7}$ i A. Pyda-Grajpel ${ }^{8}$, dowodząc, że pod pewnymi względami zbliżona jest ona do mowy i języka werbalnego. Można zatem spojrzeć na dzieło sztuki muzycznej jak na komunikat zakorzeniony w konkretnym kręgu kulturowym, czasie i przestrzeni. Jego odbiorcy, oprócz satysfakcji estetycznej, mogą liczyć na wgląd w daną kulturę, jej wartości i specyfikę. Za komunikat można uznać utwór muzyczny (także ten bez słów), jak również sam akt jego wykonania. Należy bowiem wziąć pod uwagę, że odtwórca zawsze jest także współtwórcą dzieła, a więc komunikuje się z słuchaczem nie tylko w imieniu kompozytora, ale też własnym, co wyraźnie wybrzmiewa w koncepcji estetycznej Romana Ingardena ${ }^{9}$. Komunikatem jest wreszcie reakcja słuchacza - natychmiastowa lub odroczona - na poznane dzieło muzyczne. W szerszym zakresie za komunikat można uznać określoną konstrukcję repertuaru muzycznego, prezentowanego słuchaczom podczas koncertów.

\section{Zagadnienia metodologiczne}

Wychodząc z założenia, że komunikowanie się należy do najważniejszych zmiennych w procesie poznania i zrozumienia Innego, autorka postanowiła przyjrzeć się szczególnej formie tego komunikowania się: muzyce, a zwłaszcza środowisku miłośników i wykonawców muzyki tzw. poważnej. Celem badań było ustalenie, czy i w jakim stopniu działalność danej instytucji kultury odzwierciedla najnowsze światowe przemiany społeczno-kulturowe: wzrost wielokulturowości i osłabienie dominacji kultury euroamerykańskiej na rzecz kultury krajów innych kontynentów, zwłaszcza Azji. Zadano pytanie, czy działalność instytucji muzycznych wpływa na zwiększenie otwartości odbiorców na inne kultury, czy przeciwnie - otwartość tę ogranicza.

Badania mają charakter wstępny. Ich celem było przede wszystkim zwrócenie uwagi na dany problem i nakreślenie dalszego pola badawczego. Z tego względu jako jedyną metodę zastosowano analizę dokumentów ${ }^{10}$. Analizowano dokumenty zastane, sporządzone w celach pozanaukowych.

Przedmiotem badań był repertuar koncertowy i inne wydarzenia artystyczne zaplanowane na sezon 2017/2018, odbywające się z udziałem wybranych orkiestr sym-

${ }^{7}$ M. Dymon, Ograniczenia notacji muzycznej a interpretacja utworów, „Wartości w Muzyce” 2013 , t. 5, s. $151-165$.

${ }^{8}$ A. Pyda-Grajpel, Regionalizm, wielokulturowość i międzykulturowość w edukacji muzycznejstan obecny i perspektywy, [w:] K. Rzędziński (red.), Edukacja wielokulturowa wyzwaniem dla nauk o wychowaniu, seria „Prace Naukowe Akademii im. Jana Długosza w Częstochowie. Pedagogika”, t. XIX, Akademia im. Jana Długosza w Częstochowie, Częstochowa 2010, s. 193-204.

9 M. Krasińska, Problem dzieła muzycznego w myśli estetycznej Romana Ingardena, „Filo-Sofija" nr 20(1)/2013, s. 101-117.

${ }_{10} \mathrm{M}$. Łobocki, Metody i techniki badań pedagogicznych, Oficyna Wydawnicza Impuls, Kraków 2009. 
fonicznych lub w zajmowanych przez nie budynkach, względnie w ramach wybranego cyklu koncertów lub festiwalu. Wykorzystano repertuar sezonu artystycznego, który rozpoczynał się w momencie przystępowania do badań, by uzyskany materiał był jak najnowszy. Do badań wybrano pięć zestawień repertuarowych; pochodziły one z jednej filharmonii i dwóch sal koncertowych (trzon repertuaru każdego z tych miejsc stanowią występy związanej z daną instytucją orkiestry symfonicznej) oraz dwóch festiwali muzyki współczesnej. $W$ trzech przypadkach analiza dotyczy instytucji krajowych, w dwóch przypadkach - zagranicznych.

Dobór repertuarów do analizy nosi znamiona doboru celowego: dążono do uzyskania jak największej różnorodności analizowanych instytucji/festiwali ze względu na miejsce ich działania, długość historii funkcjonowania, reprezentowaną kulturę. Filharmonię Łódzką wybrano, ponieważ jest to druga co do starszeństwa, po stołecznej, orkiestra filharmoniczna w Polsce i znajduje się w mieście znanym ze swej wielokulturowej historii. Międzynarodowy Festiwal Muzyki Współczesnej „Warszawska Jesień" to najstarszy w tej części Europy i jeden z najbardziej prestiżowych na świecie przeglądów muzyki najnowszej. Dla kontrastu, festiwal „Sonus ex Machina” ma za sobą dopiero pierwszą edycję. Orkiestrę Symfoniczną w Szanghaju uznano za godną uwagi między innymi ze względu na jej historię: jest najstarszą chińską orkiestrą symfoniczną, której dzieje sięgają 1879 roku. Królewska Orkiestra Filharmoniczna w Sztokholmie, działająca pod patronatem rodziny królewskiej, to zespół bardzo prężnie działający, a umiejscowienie w stolicy Szwecji - kraju znanego z otwartości wobec imigrantów i szeroko zakrojonej edukacji równościowej, czyni ją szczególnie wartą uwagi.

Źródłem analizy były oficjalne strony internetowe wybranych instytucji, które stanowią obecnie najaktualniejsze źródło informacji, bardziej wiarygodne od źródeł drukowanych. O aktualności przekazywanych w ten sposób informacji świadczy między innymi możliwość zakupu przez Internet biletów na wybrane wydarzenie. $\mathrm{W}$ przypadku zmian $\mathrm{w}$ repertuarze najpierw są one anonsowane $\mathrm{w}$ Internecie. Zawarte $\mathrm{w}$ artykule informacje na temat specyfiki pracy instytucji artystycznych i koncertujących muzyków pochodzą z pozauniwersyteckiej praktyki zawodowej autorki oraz z wywiadów z artystami i audycji o tematyce muzycznej, prezentowanych między innymi w programie radiowym Dwójka.

Analizowano sposób konstruowania repertuaru poszczególnych orkiestr/instytucji/festiwali, a zwłaszcza ilość muzyki kompozytorów pozaeuropejskich w stosunku do utworów z tzw. kanonu wykonawczego. Zwracano uwagę na sposób ich umieszczenia w programie - relacje wobec innych utworów. W połączeniu z podstawowymi informacjami na temat danej instytucji/festiwalu oraz specyfiki pracy tamże, pozwoliło to wnioskować o przyczynach decyzji repertuarowych. Zastosowano ilościowe badanie danych zawartych $\mathrm{w}$ dokumentach (stosunek liczby utworów kompozytorów europejskich do liczby utworów kompozytorów reprezentujących inne kontynenty) oraz badanie jakościowe: ocena sposobu budowania repertuaru, kontekstu prezento- 
wania utworów z innych kręgów kulturowych, grupy docelowej. Analizie ilościowej poddano tylko koncerty symfoniczne, ponieważ repertuar koncertów kameralnych ustalany jest z mniejszym wyprzedzeniem i podlega częstszym zmianom. Należy zaznaczyć, że wyliczenia procentowe mają jedynie charakter orientacyjny - różnym utworom nie można nadawać takiego samego znaczenia, gdyż w układzie koncertu pełnia różną rolę, mają różny czas trwania itp.

\section{Analiza repertuarów wybranych instytucji muzycznych z punktu widzenia wielokulturowości}

Repertuar koncertów i spektakli muzycznych oferowanych przez orkiestry, filharmonie, teatry jest wynikiem istnienia tzw. kanonu wykonawczego, czyli zbioru utworów uznawanych za najważniejsze w historii muzyki. Składa się on niemal wyłącznie $\mathrm{z}$ utworów kompozytorów europejskich począwszy od epoki baroku do połowy wieku XX - utwory wcześniejsze wykonywane są przez muzyków i zespoły specjalizujące się w tzw. wykonawstwie historycznym, utwory współczesne prezentuje się niemal wyłącznie podczas poświęconych muzyce najnowszej przeglądów i festiwali. Kanon wykonawczy jest silnie zakorzeniony w przyzwyczajeniach melomanów i współczesnym życiu muzycznym, choć jego istnienie jest stosunkowo krótkie - ta idea narodziła się dopiero w XIX wieku. Jak zauważa Karolina Szymańska: „Świadczy to, iż kanon jest jedynie czyjąś wizją, czyimś punktem widzenia, czyimiś preferencjami i wyborem, a nie odwiecznym i niezmiennym prawem" ${ }^{\prime 1}$. Obecnie, wraz z przemianami we wszystkich dziedzinach życia i kultury, kanon wykonawczy muzyki poważnej ulega rozluźnieniu i wzbogaceniu. Działalność instytucji kultury ewoluuje w kierunku większej różnorodności oferty kulturalnej i edukacyjnej dla różnych grup wiekowych i społecznych oraz zmierza do zachęcania odbiorców do aktywności w poznawaniu sztuki, w tym do jej współtworzenia.

Analiza repertuaru i pozakoncertowych wydarzeń w wybranych instytucjach muzycznych ujawnia zdecydowaną, choć niejednakowo silnie zaznaczoną, dominację kultury europejskiej, zarówno w instytucjach znajdujących się w Europie, jak i poza nią.

W Filharmonii Łódzkiej ${ }^{12}$ na sezon artystyczny 2017/2018 zaplanowano 32 koncerty symfoniczne, podczas których miało zostać wykonanych ok. stu utworów. $\mathrm{W}$ repertuarze zdecydowanie dominowały utwory z tzw. kanonu, czyli od późnego baroku do połowy XX wieku. Najczęściej pojawiały się nazwiska W.A. Mozarta, L. van Beethovena, F. Schuberta, A. Dvořáka itd. Spośród kompozytorów pozaeuropejskich występowali jedynie Amerykanie - do programów włączano najbardziej

${ }^{11}$ K. Szymańska, Wpływ feminizmu na muzykologie - women's studies, gender i kobiety w muzyce, [w:] M. Grochalska, W. Sawczuk (red.), Uniwersyteckie gry - czy płeć ma znaczenie? Wybrane dyskursy społeczno-edukacyjne, Wydawnictwo Adam Marszałek, Toruń 2011.

${ }^{12}$ http://filharmonia.lodz.pl/pl/koncerty-symfoniczne (dostęp: 1-25.09.2017). 
znane utwory z ich dorobku, takie jak Adagio Samuela Barbera, uwertura do operetki Kandyd Leonarda Bernsteina czy cztery epizody taneczne z baletu Rodeo Aarona Coplanda. Warto podkreślić, że kompozytorzy amerykańscy w znacznym stopniu byli i są spadkobiercami europejskiej tradycji i wychowankami europejskich szkół kompozytorskich. Nie bez powodu w rozważaniach kulturoznawczych często łączy się te sfery wpływów, mówiąc o kręgu kultury euroamerykańskiej. Ogółem, w Filharmonii Łódzkiej utwory pozaeuropejskie znalazły się w programie 5 koncertów na 32 zaplanowane (15\%). Utworów pozaeuropejskich było 9 na 100 wszystkich utworów symfonicznych (9\%).

Dominacja Europejczyków dotyczy także wykonawców muzyki. Wśród wykonawców w Filharmonii Łódzkiej znalazła się południowokoreańska skrzypaczka Bomsori Kim, ona jednak występuje raczej jako reprezentantka kultury euroamerykańskiej: obecnie studiuje w nowojorskiej Juilliard School, jest laureatką konkursów międzynarodowych odbywających się w Europie (im. P. Czajkowskiego w Moskwie, im. Królowej Elżbiety w Brukseli, ARD w Monachium, im. J. Joachima w Hanowerze oraz im. H. Wieniawskiego w Poznaniu), wykonała zaś Koncert skrzypcowy Rosjanina Piotra Czajkowskiego.

$\mathrm{Na} 33$ odrębne programy Królewskiej Orkiestry Symfonicznej w Sztokholmie ${ }^{13}$ (wiele $\mathrm{z}$ nich powtarzano kilkakrotnie) w omawianym sezonie zauważono 6 programów z kompozycjami pozaeuropejskimi (amerykańskimi, kanadyjskimi, australijskimi), co stanowi 18\%. Można sądzić, że repertuar odzwierciedla wartości, z których znana jest szwedzka kultura, gdyż wyjątkowo licznie reprezentowani są kompozytorzy skandynawscy, zwłaszcza szwedzcy, a także kobiety-kompozytorki (głównie z krajów skandynawskich). Większa różnorodność repertuarowa tej instytucji jest możliwa dzięki programom wykraczającym poza tradycyjnie rozumianą muzykę poważną, głównie koncertom jazzowym, będącym okazją do występów artystów afrykańskich, takich jak Oumou Sangaré czy Richard Bona Mandekan Cubano (w ramach Stockholm Jazz Festival). Specyfika muzyki jazzowej sprawia, że wykonują oni własne kompozycje. Cechą wyróżniającą sali koncertowej w Sztokholmie jest też wyjątkowo bogata oferta wydarzeń o charakterze edukacyjnym, bazują one jednak na utworach $\mathrm{z}$ koncertowego kanonu. Większa liczba utworów pozaeuropejskich w repertuarze sztokholmskim w stosunku do łódzkiego może być wyjaśniona nie tylko względami ideowymi: są to w większości kompozycje współczesne, które wymagają znaczących nakładów finansowych (konieczność opłacania praw autorskich do 70 lat po śmierci kompozytora).

Euroamerykański kanon repertuarowy legł także u podstaw programu koncertów w sali koncertowej w Szanghaju ${ }^{14}$. Został on wzbogacony nazwiskami twórców azjatyckich. Spośród 65 koncertów znajdujących się w planie sezonu 2017/2018 tylko

\footnotetext{
${ }^{13}$ http://www.konserthuset.se/en/programme/calendar/ (dostęp: 1-25.09.2017)].

${ }^{14}$ http://www.shsymphony.com/concert-calendar.html (dostęp: 1-25.09.2017).
} 
do siedmiu wprowadzono muzykę tego kontynentu (11\%), w większości przypadków łącząc ją w ramach jednego wieczoru z utworami kompozytorów europejskich, np.: Koncert podwójny na wiolonczele i sheng (tradycyjny chiński instrument dęty) Zhao Lin sąsiadował z Koncertem wiolonczelowym E. Elgara; Koncert fortepianowy B-dur Ding Shande został wykonany tego samego wieczoru, co utwór Johannesa Brahmsa. Samodzielny koncert przeznaczono na prezentację dorobku zmarłego w roku 2017 chińskiego kompozytora Zhu Jian’er. Oprócz nazwisk twórców chińskich w programie znalazła się Japonka Keiko Abe oraz Australijczyk Carl Vine. Prezentowani kompozytorzy azjatyccy to twórcy współcześni, nadal żyjący lub niedawno zmarli. Chińska muzyka artystyczna od początku XX wieku rozwija się w znacznym stopniu pod wpływem muzyki europejskiej; muzyka wcześniejsza raczej nie jest prezentowana w salach koncertowych, między innymi ze względu na wymogi instrumentarium. Wyjątek w omawianym sezonie w Szanghaju stanowił występ Tang Jun Qiao Bamboo Flute Orchestra - zespołu pod kierunkiem Tang Jun Qiao, mistrzyni w grze na tradycyjnym flecie chińskim dizi.

W programie jubileuszowej, 60. edycji Międzynarodowego Festiwalu Muzyki Współczesnej „Warszawska Jesien’”15, który odbył się w dniach 15-23 września 2017 roku, figurowały nazwiska 67 kompozytorów. Wśród nich znalazły się zaledwie 4 nazwiska twórców spoza Europy (6\%): Amerykanin Ashley Fure, twórczyni muzyki elektronicznej Unsuk Chin z Korei Południowej, zmarły w 1995 roku Koreańczyk Isang Yun, który znaczną cześć życia spędził w Niemczech, oraz Chińczyk Wenchen Qin (utwór na zamówienie „Warszawskiej Jesieni”). Należy jednak wziąć pod uwagę, że środowisko kompozytorów i wykonawców muzyki współczesnej (nie muzyki popularnej) jest stosunkowo niewielkie i w znacznym stopniu kosmopolityczne: młodzi twórcy spotykają się na warsztatach o światowym zasięgu, takich jak renomowane warsztaty w niemieckim Darmstadt, i biorą udział w międzynarodowych konkursach. Wielu z nich, choć urodzonych w Azji czy Australii, ma za sobą studia w Europie lub Stanach Zjednoczonych. Korzystają z tych samych zdobyczy technologicznych w zakresie tworzenia muzyki elektronicznej. W związku z tym, mimo różnorodności stylów kompozytorskich, ich praca twórcza ma ze sobą wiele wspólnego. Dopiero kompozytorzy o ustalonej renomie niekiedy wprowadzają do swego warsztatu więcej pierwiastków właściwych rodzimej kulturze, jak ma to miejsce u Indonezyjczyka Michaela Asmary, który, tworząc na instrumenty zachodnie, stara się pisać w stylu gamelanu (zespołu indonezyjskiego) i oddać poczucie czasu typowe dla muzyki jawajskiej. Jego utwór, jako pierwszego Indonezyjczyka w programie „Warszawskiej Jesieni", został zaprezentowany na tym festiwalu w $2014 \mathrm{r}^{16}$

${ }^{15}$ http://www.warszawska-jesien.art.pl/wj2017/program-i-bilety-2017/program (dostęp: $1-25.09 .2017)$.

${ }^{16}$ Radio „Dwójka” - Azjatyckie festiwale muzyki współczesnej, audycja z cyklu Nokturn, prowadzenie Krzysztof Dziuba, emisja: 12.10.2015, http://www.polskieradio.pl/8/740/Artykul/1529360,Azjatyckie-festiwale-muzyki-wspolczesnej (dostęp: 22.10.2017). 
Większą otwartością cechuje się nowy festiwal muzyki współczesnej „Sonus ex Machina" ${ }^{17}$ w Poznaniu, którego pierwsza edycja odbyła się w dniach 27-28 października 2017 roku. W programie umieszczono wyjątkowo dużo utworów kompozytorów z innych kontynentów. Na festiwalu dwa spośród trzech koncertów zawierały muzykę pozaeuropejską (lub wręcz na niej bazowały).

Festiwal to eksperyment - przestrzeń spotkań dla artystów z bardzo różnym zapleczem kulturowym, a jednocześnie okazja dla publiczności do zetknięcia się ze sztuką, która powstaje na takim niecodziennym styku. Daje do myślenia, na ile jako ludzie mieszkający w odległych miejscach globu i różnych środowiskach jesteśmy do siebie podobni, a na ile odmienni.

- mówił współtwórca festiwalu Stanisław Suchora ${ }^{18}$.

\section{Niewykorzystany potencjał międzykulturowości w repertuarze koncertowym - wnioski z badań}

Jak wskazuje powyższa analiza, repertuar koncertów i festiwali muzyki poważnej jest w znacznym stopniu podyktowany tradycją. Liczba utworów pozaeuropejskich jest niewielka i nie odzwierciedla przemian społeczno-gospodarczych oraz kulturalnych w świecie współczesnym. Stanowi to wyrazistą różnicę w stosunku do innych dziedzin sztuki, takich jak sztuki plastyczne, teatr czy film. Nieco inaczej sytuacja przedstawia się w wykonawstwie - wśród wirtuozów instrumentów, np. fortepianu i skrzypiec, a także wśród dyrygentów, wielu jest przedstawicieli innych kultur. Tutaj także, spośród nie-Europejczyków, prym wiodą Amerykanie i Azjaci, natomiast niewielu jest mieszkańców Ameryki Południowej, Afryki i Australii. Artyści niezależnie od kraju pochodzenia, by zaistnieć na światowych konkursach, które są przepustką do sławy, wykonują przede wszystkim muzykę kompozytorów europejskich. Nie bez znaczenia jest fakt, że orkiestra symfoniczna stanowi twór kultury europejskiej, zatem kompozytorzy azjatyccy czy afrykańscy, tworząc na taki zespół, w pewnym stopniu przejmują estetykę i sposób myślenia właściwe dla kultury euroamerykańskiej. Można więc mówić o ciągłej dominacji kultury europejskiej - w odróżnieniu od gospodarki czy finansów - i swego rodzaju „artystycznym kolonializmie”. Także przy uwzględnieniu repertuaru koncertów kameralnych (jak również edukacyjnych i jazzowych) w wybranych instytucjach nie dało się zauważyć dążenia do przeformułowania oferty artystycznej w duchu obecnych przemian kulturowo-społecznych. Działalność po-

${ }^{17}$ https://www.facebook.com/sonusexmachinafestival/ (dostęp: 1-25.09.2017).

18 A. Jowsa, I edycja festiwalu muzyki współczesnej Sonus ex Machina, artykuł na portalu dzieje.pl, prowadzonym przez Muzeum Historii Polski oraz Polską Agencję Prasową, pod patronatem Ministerstwa Kultury i Dziedzictwa Narodowego, http://dzieje.pl/kultura-i-sztuka/i-edycja-festiwalu-muzyki-wspolczesnej-sonus-ex-machina (dostęp: 23.10.2017). 
wyższych instytucji w zakresie poddanym badaniu nie sprzyja otwartości odbiorców na inne kultury.

Większa otwartość na inne kultury cechuje środowisko osób związanych z muzyką współczesną. Otwartość i brak uprzedzeń stanowić muszą immanentną cechę każdego, kto chce orientować się w dynamicznie zmieniającym się krajobrazie muzyki współczesnej i czerpać z niej satysfakcję estetyczną. Zwolennicy współczesności $\mathrm{w}$ muzyce stanowią jednak grono stosunkowo małe, nawet w porównaniu z niewielką też liczbą melomanów.

Określony sposób formowania repertuaru zawiera ukryty komunikat dla odbiorców: jest nim ocena tego, jaka muzyka (kompozytor, styl, narodowość) jest warta słuchania i godna wykonania w danym miejscu, a jaka - nie dość znacząca czy ciekawa. Hołdowanie tradycji może stwarzać wrażenie, że kultura pozaeuropejska nie wydała utalentowanych kompozytorów. W skrajnym przypadku może to budzić przekonanie, iż przedstawiciele obcych kultur to „barbarzyńcy”, niemający w tej dziedzinie nic do zaoferowania. Stąd już tylko krok, by postrzegać ich wyłącznie przez pryzmat negatywnych informacji, których nie brak w środkach masowego przekazu.

Inaczej kształtuje się sytuacja muzyki popularnej, gdzie wpływy kultur pozaeuropejskich są znacznie silniejsze, o czym świadczy choćby wielka i nieoczekiwana popularność przeboju południowokoreańskiego Gangnam style, wylansowanego w 2012 roku. Należy to wiązać z większą zmiennością i dynamizmem zjawisk w kulturze popularnej oraz łatwością przepływu dóbr kultury, który opiera się na pośrednictwie mediów (Gangnam style zdobył popularność dzięki umieszczeniu w serwisie youtube.com). Żywot przebojów muzyki rozrywkowej jest jednak znacznie krótszy, a fascynacja nimi - płytsza, niż w przypadku muzyki poważnej.

Powyższa konstatacja prowadzi nieuchronnie do pytania o przyczyny tak słabej obecności muzyki innych kontynentów w programach koncertowych. Są one złożone. Niebagatelne znaczenie mają trudności obiektywne, takie jak brak odpowiednich instrumentów (kompozytorzy azjatyccy często wprowadzają do swoich utworów instrumenty ludowe właściwe dla własnego regionu, choć nieraz traktują je na sposób europejski), niewielka liczba muzyków potrafiących na nich grać czy wyższe niż zwykle koszty zdobycia partytur. Dają o sobie znać także różnice kulturowe, na przykład inne poczucie czasu w krajach Azji Południowo-Wschodniej, które sprawia, że niemal wszystko jest tam załatwiane "na ostatnią chwilę". W zasadzie uniemożliwia to zakontraktowanie artysty i kompozytora $\mathrm{z}$ dwu-, trzyletnim wyprzedzeniem, co jest standardem w euroamerykańskim kręgu kulturowym ${ }^{19}$.

Poza trudnościami obiektywnymi istotne znaczenie ma poczucie wartości określonych kultur u słuchaczy. Melomani, zwłaszcza osoby uczęszczające na „standardowe" koncerty symfoniczne, mają gusta raczej ustalone i niełatwo akceptują zmiany, co trafnie ilustruje popularny niemiecki termin „Beethoven-Tchaikovsky Publikum”.

\footnotetext{
${ }^{19}$ Azjatyckie festiwale muzyki współczesnej, dz. cyt.
} 
Wprowadzanie doń nowych utworów czy nazwisk musi odbywać się stopniowo i ostrożnie, o czym najlepiej wiedzą dyrygenci i dyrektorzy artystyczni. Częstą praktyką jest łączenie w jednym koncercie utworu bardzo znanego i lubianego, który pełni funkcję wabika, z utworem nieznanym, na przykład współczesnym. Próby narzucenia publiczności radykalnych zmian zwykle kończą się porażką. Jak wskazuje Krzysztof Kwiatkowski, nie jest to problem wyłącznie europejski:

Wciąż jednak komentatorzy chińskiego życia muzycznego są zgodni, że słuchacze koncertów to, w znacznie większym stopniu niż na Zachodzie, typowa Beethoven-Tchaikovsky Publikum - nawet koncerty muzyki barokowej cieszą się niewielkim powodzeniem, nie mówiąc już o muzyce dawnej albo nowoczesnej ${ }^{20}$.

Zachowawczość w budowaniu repertuaru może też wynikać ze specyfiki pracy w danej instytucji. Wprowadzanie do programów nowych utworów wymaga ich wcześniejszego poznania, a na to - wbrew pozorom - nie zawsze wystarcza pracownikom czasu i pieniędzy. Zmiana w konstruowaniu programów wymaga zmiany w sposobie pracy działów, które są za to odpowiedzialne, to z kolei wymaga decyzji na szczeblu dyrektorskim.

Zmiany w konstruowaniu repertuarów koncertowych nie są, wbrew pozorom, zmianami drobnymi. Repertuar jest bowiem zakorzeniony $\mathrm{w}$ tradycji, zwyczajach kulturowych i nawykach spędzania wolnego czasu. Jego zmiany wymagają przeobrażenia upodobań odbiorców, a wcześniej - pracowników sektora kultury oraz decydentów. Wymagają podjęcia ryzyka.

\section{Podsumowanie}

Zagadnienie włączania innych kultur do programu wydarzeń kulturalnych w Europie jest szerokie i warte badań. Wiele interesujących wniosków mogłyby przynieść analizy obejmujące inne dziedziny kultury, zwłaszcza teatr, film i sztuki plastyczne, które są dziedzinami o znacznie wyższym stopniu semantyczności. W tym obszarze badawczym zarysowują się też inne tematy, takie jak uwarunkowania i kontekst prezentacji europejskiego dorobku kultury na innych kontynentach. Do wszechstronności i pogłębienia wniosków przyczyniłoby się zróżnicowanie metod i technik badawczych, m.in. zastosowanie wywiadów i obserwacji.

Truizmem jest stwierdzenie, że otwartość na inne kultury wzbogaca. Znajomość obcej kultury ułatwia porozumienie, gdyż to, co znajome, wydaje się mniej groźne. Wzajemne poznanie ułatwia też uświadomienie sobie wzajemnych podobieństw, a to osłabia uprzedzenia, budzi sympatię. Świadomość komunikacyjnej funkcji sztuki za-

${ }^{20}$ K. Kwiatkowski, Duch, cele i środki. Asymilacja muzyki zachodniej w Chinach (3), „Ruch Muzyczny", nr 16/2007, http://www.ruchmuzyczny.pl/PelnyArtykul.php?Id=465 (dostęp: 22.10.2017). 
chęca do wykorzystania aktywności artystycznej w działaniach o takim charakterze. Jak wskazano wyżej, obecnie odbywa się to w niewielkim zakresie.

$\mathrm{Na}$ gruncie pedagogiki teoretycznego uzasadnienia ku temu dostarcza między innymi koncepcja wychowania estetycznego Herberta Reada, który zakładał jedność życia i sztuki. Uznawał on, że kontakt ze sztuką może być nie tylko celem samym w sobie, ale także środkiem, pozwalającym w skuteczny i atrakcyjny sposób osiągać cele wychowawcze ${ }^{21}$.

Krystyna Najder-Stefaniak wyróżnia cztery typy różnicy występującej podczas spotkań kultur: „albo-albo” (różnica dyskwalifikuje jeden z członów tego, co różne), myślenie komplementarne (dopełnienie, zsumowanie tego, co spotykające się strony wnoszą do sytuacji), myślenie dialektyczne (otwarte, pozwalające na rozwój, odkrycie potencjału sytuacji) oraz myślenie synergiczne (przejście na poziom metarefleksji, zrozumienie uwarunkowań wzajemnej inności, zachęta do twórczości, możliwość przekraczania granic własnej tożsamości bez rezygnacji z niej) ${ }^{22}$. Najwartościowsze jest myślenie synergiczne, wymaga ono jednak największej dojrzałości odbiorców. Wśród słuchaczy muzyki poważnej jest wielu melomanów, którzy na tę dojrzałość mogliby się zdobyć. Na razie jednak dominuje myślenie komplementarne, w którym sumowanie wkładu obu stron często ogranicza się do połączenia na zasadzie szeregowania w pojedynczej sytuacji obcowania z kulturą. Zmiana nawyków percepcyjnych wymaga wiele wysiłku, gdyż wytrąca z poczucia bezpieczeństwa, a niepewność ta może być wzmacniana wydarzeniami przypadkowo współistniejącymi w innych dziedzinach życia społecznego.

Obawy, nawet nieuświadomione, mogą wiązać się z poczuciem zagrożenia dla bezpieczeństwa kulturowego ${ }^{23}$. Zetknięcie kultur wzbogaca je tylko wtedy, gdy jest to kontakt dobrowolny, niewymuszony i nienarzucony. Prezentacja dorobku obcych kultur tylko wtedy ma sens, gdy nie jest odbierana jako zagrożenie dla kultury własnej. Otwartość na nowe nie może być mylona z wymogiem rezygnacji z własnej tożsamości czy uznania jej niższości, w przeciwnym razie będzie jedynie konwencjonalnym gestem uprzejmości lub obowiązku (?), podszytym strachem. Działania te nie mogą mieć formy nacisku, gdyż ten kojarzy się z systemami totalitarnymi, które cechuje wrogość wobec obcych i daleko posunięta kontrola kultury, w tym muzyki, w zakresie doboru repertuaru i zasad tworzenia dzieł sztuki.

Zbliżenie do innych kultur nie powinno ograniczać się do prezentacji ich dorobku, ale uwzględniać także działania edukacyjne, ułatwiające ich zrozumienie. Działania promujące kulturę przybyszów w Europie będą dalece niewystarczające, jeśli nie

${ }^{21}$ H. Read, Wychowanie przez sztukę, Zakład Narodowy im. Ossolińskich, Wrocław 1976.

${ }^{22}$ K. Najder-Stefaniak, Znaczenie spotkań w wielokulturowym świecie, „Drohiczyński Przegląd Naukowy", nr 8/2016, s. 221-233.

${ }^{23}$ P. Żarkowski, Miejsce bezpieczeństwa kulturowego we współczesnym świecie, [w:] P. Żarkowski (red.), Współczesne bezpieczeństwo kulturowe, Wydawnictwo Uniwersytetu Przyrodniczo-Humanistycznego w Siedlcach, Siedlce 2014. 
zostaną połączone z promocją europejskich kompozytorów i wykonawców na innych kontynentach oraz wśród imigrantów. Jest to tym bardziej ważne, że wskazuje się, iż kulturę europejską cechuje stosunkowo największa otwartość. Pogłębianie tej otwartości bez jakichkolwiek działań po drugiej stronie powiększałoby więc asymetrię we wzajemnych relacjach.

Stymulowanie procesu poznawania Innego jest jednym z większych wyzwań, stojących przed pedagogami, badanie tego procesu zaś - pasjonującym i wartościowym zagadnieniem dla badaczy. Jak wskazuje M. Głażewski, „waśnie i akty agresji są w ogromnej mierze pochodną [...] pospolitych deformacji komunikacyjnych, niewłaściwego kodowania i dekodowania zawartości semantycznej przekazu"24. Wykonanie i percepcja utworu muzycznego są także aktami komunikacyjnymi. Daje to nadzieję, że w ramach kultury muzycznej możliwe jest zbliżenie się do Innego i poznanie go. Sztuka pozwala na rozpoczęcie procesu poznania od najlepszej, nie zaś najgorszej strony ewentualnego partnera dialogu, co dobrze rokuje wzajemnym kontaktom. Jeśli spojrzymy na sztukę jak na jeden ze sposobów komunikowania się, możemy wykorzystać ją jako pomocnika i pośrednika w tym procesie.

\section{Bibliografia}

Azjatyckie festiwale muzyki współczesnej, audycja z cyklu „Nokturn” w radiu „Dwójka”, prowadzenie Krzysztof Dziuba, emisja: 12.10.2015, http://www.polskieradio.pl/8/740/Artykul/1529360,Azjatyckie-festiwale-muzyki-wspolczesnej (dostęp: 22.10.2017).

Czaja J., Bezpieczeństwo kulturowe. Zarys problematyki, Krakowska Szkoła Wyższa im. Andrzeja Frycza Modrzewskiego, Kraków 2004.

Dymon M., Ograniczenia notacji muzycznej a interpretacja utworów, „Wartości w Muzyce" 2013, t. 5, s. 151-165.

Głażewski M., Sens dialogu jako medium komunikacji, „Kultura i Wychowanie”, nr 5(1)/2013, s. 18-32.

Golka M., Socjologiczny obraz sztuki, ars nova, Poznań 1996.

Jowsa A., I edycja festiwalu muzyki współczesnej Sonus ex Machina, http://dzieje.pl/ kultura-i-sztuka/i-edycja-festiwalu-muzyki-wspolczesnej-sonus-ex-machina (dostęp: 23.10.2017).

Kapuściński R., Spotkanie z Innym - jako wyzwanie XXI wieku, „Gazeta Wyborcza”, 1.10.2004, http://wyborcza.pl/1,76842,2318704.html (dostęp: 28.04.2018).

Krasińska M., Problem dzieła muzycznego w myśli estetycznej Romana Ingardena, „Filo-Sofija” nr 20(1)/2013, s. 101-117.

${ }^{24}$ M. Głażewski, Sens dialogu jako medium komunikacji, „Kultura i Wychowanie”, nr 5(1)/2013, s. $18-32$. 
Krycki M., Komunikowanie międzynarodowe i komunikowanie międzykulturowe, [w:] R. Zenderowski, K. Cebul, M. Krycki (red.), Międzynarodowe stosunki kulturalne, Wydawnictwo Naukowe PWN, Warszawa 2010.

Kwiatkowski K., Duch, cele i środki. Asymilacja muzyki zachodniej w Chinach (3), „Ruch Muzyczny”, nr 16/2007, http://www.ruchmuzyczny.pl/PelnyArtykul. php?Id=465 (dostęp: 22.10.2017).

Łobocki M., Metody i techniki badań pedagogicznych, Oficyna Wydawnicza Impuls, Kraków 2009.

Najder-Stefaniak K., Znaczenie spotkań w wielokulturowym świecie, „Drohiczyński Przegląd Naukowy", nr 8/2016, s. 221-233.

Pyda-Grajpel A., Regionalizm, wielokulturowość i międzykulturowość w edukacji muzycznej - stan obecny i perspektywy, [w:] K. Rzędziński (red.), Edukacja wielokulturowa wyzwaniem dla nauk o wychowaniu, seria „Prace naukowe Akademii im. Jana Długosza w Częstochowie. Pedagogika", t. XIX, Akademia im. Jana Długosza w Częstochowie, Częstochowa 2010.

Read H., Wychowanie przez sztukę, Zakład Narodowy im. Ossolińskich, Wrocław 1976.

Szymańska K., Wplyw feminizmu na muzykologie - women's studies, gender i kobiety w muzyce, [w:] M. Grochalska, W. Sawczuk (red.), Uniwersyteckie gry - czy płeć ma znaczenie? Wybrane dyskursy społeczno-edukacyjne, Wydawnictwo Adam Marszałek, Torun 2011.

Zalewska-Pawlak M., Rola sztuki w wychowaniu. Polska tradycja pedagogiczna, Wydawnictwo Uniwersytetu Łódzkiego, Łódź 2001.

Żarkowski P., Miejsce bezpieczeństwa kulturowego we wspótczesnym świecie, [w:] P. Żarkowski (red.), Wspótczesne bezpieczeństwo kulturowe, Wydawnictwo Uniwersytetu Przyrodniczo-Humanistycznego w Siedlcach, Siedlce 2014.

Analizowane strony internetowe $\mathrm{z}$ repertuarem filharmonii i festiwali muzycznych: http://filharmonia.lodz.pl/pl/koncerty-symfoniczne (dostęp: 1-25.09.2017). http://www.konserthuset.se/en/programme/calendar/ (dostęp: 1-25.09.2017). http://www.shsymphony.com/concert-calendar.html (dostęp: 1-25.09.2017). http://www.warszawska-jesien.art.pl/wj2017/program-i-bilety-2017/program (dostęp: 1-25.09.2017).

https://www.facebook.com/sonusexmachinafestival/ (dostęp: 1-25.09.2017). 


\section{The Western canon in classical music as a space of meeting with The Other}

Abstract: This article considersprocesses of exploring and popularising the culture of other nations and civilisations through the example of classical music in the context of cultural safety. The sense of cultural safety, difficult in a changing world, is not possible without openness to the Other, which, in turn, cannot be obtained without appreciating one's own culture's values. Taking this line, the author analyses the activity of selected concert halls and contemporary music festivals in Poland and abroad (in Europe and outside). These cultural events manifest various interesting phenomena related to tradition, listeners' customs, social expectations towards cultural institutions, cross-cultural differences, etc. The performance and perception of a musical piece are communicative acts. Given the right circumstances, they make it possible to come closer to the Other and get to know Him/Her.

Keywords: musical culture, popularising music, cultural safety

About the author: Magdalena Sasin Ph. D., assistant professor at the University of Łódź, Faculty of Educational Sciences, Department of Art Education and Creative Pedagogy. Scientific interests: aesthetic and artistic education, especially music education; media education; popularizing art in children, teenagers and adults in outside-school institutions, in media and non-formal learning (family, friends, interests, free time). 


\title{
Komfort wyboru czy wybór komfortu? O strategiach edukacyjnych w szkole artystycznej (na przykładzie własnych doświadczeń nauczycielskich)
}

\begin{abstract}
Streszczenie: Jedną z metafor współczesnego świata jest metafora supermarketu. Zarazem supermarket to synonim sklepu gorszej jakości. Ale supermarket niesie ze sobą także komfort wyboru. Supermarket jako przestrzeń wyboru winien być inspiracją dla edukacji. Mam na myśli takie konstruowanie przez nauczyciela procesu, by pozwalał uczniowi na faktyczny wybór obszarów czy metod pracy. Owszem, nadal kluczową rolę w tym ujęciu pełni nauczyciel, ale jako pomysłodawca i animator atrakcyjnych zadań, z których uczeń wybiera te dla niego najbardziej pociągające. I to on - uczeń jest de facto głównym aktorem w tym procesie. $\mathrm{W}$ taki supermarketowy paradygmat wpisują się przedsięwzięcia, które opracowałam i wdrożyłam w Liceum Plastycznym w Poznaniu. Są to warsztaty „Uczeń bierny - uczeń aktywny”, innowacja pedagogiczna „Osobowość przedmiotu”, a także działanie projektowe „Barokowy supermarket” wieńczące kolejną innowację pedagogiczną „Gra o sztukę".
\end{abstract}

Słowa kluczowe: edukacja artystyczna, innowacje pedagogiczne, sztuka, dydaktyka, historia sztuki

\footnotetext{
Karolina Prymas-Jóźwiak - mgr historii sztuki, nauczyciel dyplomowany, edukator, trener, absolwentka studiów podyplomowych z Wiedzy o Kulturze, Akademii Trenera oraz Neurodydaktyki. Praktyk metodologii design thinking i myślenia wizualnego w edukacji. Autorka innowacji pedagogicznych pt. „Osobowość przedmiotu” oraz „Gra o sztukę. Educatorium barokowe”. Pomysłodawczyni i koordynatorka projektów edukacyjnych. Członek Stowarzyszenia Historyków Sztuki. Zainteresowania badawcze dotyczą dydaktyki historii sztuki, edukacji artystycznej, metodologii uczenia się - nauczania i pedagogiki twórczości.
} 


\section{Wprowadzenie}

Jedną z metafor współczesnego świata, jaka funkcjonuje w obiegu współczesnej kultury za sprawą Gordona Mathewsa jest metafora supermarketu1. Tutaj wszystko jest na sprzedaż, w zasięgu ręki, dostępne od świtu do nocy. Możesz dotknąć, przymierzyć, powąchać, nawet zdegustować, możesz przeczytać ulotki, zanim coś kupisz. A kupisz na pewno, jeśli nie ten, to inny towar. Jednocześnie supermarket to synonim produktu gorszej jakości, gigant, który wchłania to, co jednostkowe i unikatowe. Obiecuje dostępność towaru „do wyczerpania zapasów”, ale także liczne okazje, promocje i korzystne raty $0 \%$. A mimo to nie kojarzy się najlepiej... Choć w XX wieku supermarkety zrewolucjonizowały sposób robienia zakupów oraz odmieniły oblicze miast i przedmieść ${ }^{2}$, to przyniosły ze sobą ważną jakość - komfort wyboru, który jest wartością samą w sobie. I choć dokonywanie go nie zawsze jest łatwe, wymaga namysłu, oceny, rozważenia potencjalnych zysków i strat, daje jednak ogromną satysfakcję, uczy samodzielności oraz odpowiedzialności i to nie tylko wtedy, gdy przynosi dobre owoce. Niekiedy wymaga odwagi. Poza tym korzystny wybór wzmacnia i buduje zaufanie do własnych osądów. Nie można przy tym zapominać, co podkreśla Mathews, że niektóre wybory mają głębokie znaczenie osobiste dla tego, kto je podejmuje. Trzeba też podkreślić za autorem, że nie oznacza to, iż w „supermarkecie wybiera się w sposób wolny”, bowiem wybory te są wielorako ograniczone ${ }^{3}$. W rzeczywistości szkolnej najpoważniejszymi determinantami są uwarunkowania wynikające z przepisów oświatowych i zwyczajów panujących w danej szkole.

Przyznać należy, że konteksty generowane przez metaforę supermarketu mogą mieć dla nauczyciela duży potencjał pozytywny, który warto wykorzystać. I to nie dlatego, by przydać nieciekawej i banalnej masowości supermarketowych towarów znamion czegoś unikatowego, luksusowego, ale żeby znaleźć skuteczne antidotum na nudną prozę szkolnej codzienności. To, co jest pociągające w supermarketowym uniwersum, to fakt, że jego klient ma wyb ór, może kupić lub nie kupić, włożyć do koszyka ten czy inny towar. To on narzuca tempo zapełniania wózka, decyduje czy stać w kolejce czy nie, powiedzieć „dzień dobry” pani kasjerce czy współpracować z kasą samoobsługową. Komfort wyboru jest tutaj sprawą kluczową, podobnie jak świadomość jego konsekwencji.

${ }^{1}$ G. Mathews, Supermarket kultury, Państwowy Instytut Wydawniczy, Warszawa 2005.

${ }^{2}$ R. Arp (red.), 1001 idei, które odmienity nasz sposób myślenia, Elipsa Publicat S.A., Poznań 2013, s. 646.

${ }^{3}$ G. Mathews, dz. cyt., s. 42. 


\section{Teoretyczne fundamenty działań}

Lata poszukiwań optymalnej dydaktycznej formuły i praktyka dydaktyczna niejednego twórczego pedagoga doprowadziły do wniosku, że idea edukacji bankowej, o jakiej pisał Paulo Freire, jest w dłuższej perspektywie nieefektywna i nużąca. W myśl tej koncepcji rolą nauczyciela jest uczenie, rolą uczniów bycie nauczanym, i to nauczyciel ma dokonywać wyboru za swoich podopiecznych, a im pozostaje jedynie poddanie się tej decyzji ${ }^{4}$. To sposób edukacyjnego działania osadzonego w koncepcji szkoły tradycyjnej, herbartowskiej, której środki - kierowanie dziećmi, karność i nauczanie wychowujące, stają się mało skuteczne w konfrontacji z wyzwaniami współczesności ${ }^{5}$ Tym bardziej metafora supermarketu może nadać perspektywiczny kierunek edukacyjnym działaniom, które winny polegać na budowaniu nowatorskiej przestrzeni edukacyjnej w ramach systemu publicznej oświaty. W niej to nastoletni uczeń, licealista - główny adresat nauczycielskich przedsięwzięć, ma dokonywać wyborów, które nie tylko przekładają się na pozyskiwanie wiedzy przedmiotowej, ale zarazem na świadome samokształcenie i tworzenie interesującej ścieżki własnego rozwoju. Bowiem jedynie w obliczu zaproponowanej - szerszej niż standardowa - oferty działań uczeń może poznać smak namysłu nad tym, co jest mu prezentowane, zmierzyć się z ryzykiem popełnienia błędu i ponoszeniem konsekwencji tej pomyłki, ale także ma szansę doświadczyć satysfakcji z trafności swojego wyboru lub jego zaniechania. Wszystko to składa się na bezcenne osobiste doświadczenie młodego człowieka, które buduje jego samodzielność i wydatnie wspiera poczucie odpowiedzialności za własną naukę. Tego rodzaju podejście wpisuje się w koncepcję pedagogiczną Celestyna Freineta, która - choć stworzona dla edukacji na poziomie elementarnym, może być przydatna w edukacji ponadpodstawowej, co podkreśla Sławomir Sztobryn ${ }^{6}$. Freinet wyznaczył pewne zręby, a jego założenia opierają się w dużej mierze na otwartości wobec działań wpisujących się w ten paradygmat. Samodzielna praca, namysł nad problemem, kooperacja obok samokształcenia, wykorzystanie manualnych zdolności ucznia w pracy nad określonymi zagadnieniami teoretycznymi (ogólnokształcącymi) bliskie są freinetowskiemu doświadczeniu poszukującemu ${ }^{7}$. To z kolei ingeruje w rzeczywistość szkolnych przyzwyczajeń i rozpowszechnia wartościowe propozycje lekcji, przekonując, że świat szkolny ma szansę nie tylko wyglądać atrakcyjniej, ale i być bardziej frapujący. O podobnym mechanizmie pisze Caroline Levine w odniesieniu do potencjału kultury masowej, która jej zdaniem „nie tylko uprzystępnia idee

${ }^{4}$ H. Kostyło, Podwójny pozór w edukacji na przykładzie koncepcji Paula Freire’a, [w:] M. Dudzikowa, K. Knasiecka-Falbierska (red.), Sprawcy i/lub ofiary działań pozornych w edukacji szkolnej, Oficyna Wydawnicza Impuls, Kraków 2013, s. 89.

${ }^{5}$ W. Okoń, Wprowadzenie do dydaktyki ogólnej, Wydawnictwo Akademickie „Żak”, Warszawa 2003, s. 38.

${ }^{6}$ S. Sztobryn, Pedagogika Celestyna Freineta, [w:] Z. Kwieciński, B. Śliwerski (red.), Pedagogi$k a$, t. 1, Wydawnictwo Naukowe PWN, Warszawa 2014, s. 356.

7 Tamże, s. 359. 
i informacje, ale też rozprzestrzenia wpływowe obrazy, tym samym przekonuje nas, że świat wygląda tak a nie in a czej. I w taki właśnie sposób wspiera powstawanie »wspólnego pojęcia« i »głównego nurtu«, które z kolei [...] kształtują nasze wartości, wybory i przekonania dotyczące tego, co możliwe, a co nie"s. Próbę wykreowania "głównego nurtu” przy założeniu, że praca ucznia może przebiegać „tak a nie inaczej” opisano w dalszej części artykułu.

\section{Nauczyciel w wielu rolach}

W kontekście metafory supermarketu lekcyjne kadry to pewna rama, w której istnieje równolegle wiele procesów angażujących tak uczniów, jak nauczycieli. Podobnie jak w pedagogice Freineta, w zależności od rodzaju zadania i potrzeb uczniów, lekcja, jak i sala lekcyjna, zmieniają swoje oblicze. Tym samym, tak często jak to możliwe dochodzi do zerwania z rutyną szkolną herbartystów, powszechną zwłaszcza w szkołach ponadpodstawowych. Jest tu zatem miejsce na chwile zatrzymania się, spojrzenia na świat za oknem czy też na estetycznie i inspirująco zaaranżowane otoczenie sali, istnieje też obszar bezpośredniej współpracy młodzieży i prowadzącego, a wreszcie przestrzeń, w której można działać całkowicie samodzielnie, może nawet w pewnej izolacji (także dźwiękowej) od otoczenia. Kluczową rolę w tym ujęciu pełni nauczyciel, jednak nie jako „przekaźnik” gotowej i zamkniętej wiedzy, ale pomysłodawca i animator atrakcyjnych zadań, to z nich uczeń wybiera te dla niego najbardziej pociągające, przy tym takie, które pozwalają mu wiedzę zdobywać i poszerzać. Pedagog nie jest kimś, kto pełni funkcję pośrednika między uczniem a światem nauki, choć nie da się zaprzeczyć, że w przypadku wychowania estetycznego przewodnik (a o takim aspekcie też można mówić w odniesieniu do działań opisywanych poniżej), który ułatwia najpełniejsze percypowanie artystycznego utworu jest nieodzowny ${ }^{9}$. Nauczyciel winien zatem widzieć siebie $\mathrm{w}$ trzech rolach: jako kreatora procesu uczenia się, inspiratora i badacza „edukacyjnego pulsu” swoich uczniów.

Początku kreacji optymalnego środowiska dydaktycznego należy szukać jeszcze przed właściwym spotkaniem z uczniami, kiedy $\mathrm{w}$ umyśle nauczyciela rodzą się pomysły i strategie, następnie powstają pomoce szkolne, zostają odkryte źródła i różnorodne narzędzia, jakimi dysponuje współczesny pedagog. W głównym nurcie edukacyjnych działań pozostaje jednak bezpośrednia współpraca nauczyciela z uczniem, która winna mieć wiele wymiarów. Mam tu na myśli tworzenie atmosfery bezpieczeństwa i wspólnego dochodzenia do wymaganego celu. Dalej - życzliwej obecności, ale też przybliżania tematu, cierpliwego wyjaśniania jego zawiłości lub snucia fascynują-

${ }^{8}$ C. Levine, Od prowokacji do demokracji. Czyli o tym, dlaczego potrzebna nam sztuka, Warszawskie Wydawnictwo Literackie Muza SA, Warszawa 2013, s. 38.

${ }^{9}$ S. Szuman, O sztuce $i$ wychowaniu estetycznym, Państwowe Zakłady Wydawnictw Szkolnych, Warszawa 1969, s. 122. 
cej opowieści, która zapada w pamięć do tego stopnia, że uczeń nie tylko zainteresuje się zagadnieniem i wróci do niego samodzielnie, ale także sięgnie po zaproponowane źródła i wejdzie na drogę pracy indywidualnej (nie chodzi o odrabianie narzuconych zadań domowych, choć i te mogą stać się elementem pracy własnej ucznia, zwłaszcza w ramach przedmiotów ścisłych). Nauczyciel-kreator procesu to także ktoś, kto co jakiś czas demonstruje uczniom możliwe wykonanie zadania, pokazuje jak organizować pracę, proponuje optymalną technikę uczenia się. Podpowiada, co jest ważne, gdzie położyć akcenty. Jednocześnie swoim podopiecznym stwarza przestrzeń do dzielenia się dotychczasową wiedzą, ich wątpliwościami, pomysłami i opiniami. Przez to nie tylko prezentuje swój kunszt, ale tym bardziej wtedy wzmacnia poczucie bezpieczeństwa ucznia, kiedy ten może widzieć w nim autorytet w danej dziedzinie. Sergiusz Hessen postulował, by nauczyciel uczył przez własne myślenie naukowe i „zarażał" nim swych uczniów, a w konsekwencji doprowadzał do takiego stanu, w którym poszczególne metody poznawcze staną się dla uczniów czymś zarazem osobistym i obiektywnym. „Opanowanie przez ucznia metody poznania naukowego polegać ma na umiejętności jej stosowania w rozwiązywaniu różnych zagadnień, na zdolności dochodzenia samemu do nowego poznania, a na najwyższym szczeblu nauki - na rozszerzaniu zakresu wiedzy przez badania własne" - twierdzi Wincenty Okoń ${ }^{10}$. Pedagog musi być też gotów swobodnie pracować z młodzieżą w różnych konfiguracjach - indywidualnie, w grupach kilkuosobowych czy też z całą klasą, w centrum działań, jak i z boku, zachowując przy tym jak najlepsze panowanie nad upływającym czasem lekcji.

W supermarkecie pracuje wyspecjalizowany personel, któremu podlegają określone obszary, nierzadko zazębiające się. Natomiast w czasie lekcji to nauczyciel musi pełnić różne role, stwarzając uczniom szerokie pole do wyboru aktywności. O funkcji kreatora procesu, pomysłodawcy rozwiązań w obrębie swojego przedmiotu była już mowa. W tym miejscu trzeba podkreślić drugi status nauczyciela jako inspiratora do rozwoju i zmiany ucznia. Osobowość, która nie tylko dysponuje aktualną wiedzą i umiejętnością jej przekazania, ale nie ukrywa też faktu bycia pasjonatem czy nawet koneserem swojej dziedziny. Jako animatora myślącego i działającego nieszablonowo, częściej szukającego własnych metod niż wykorzystującego gotowe rozwiązania. Kogoś, kto nie boi się eksperymentów, słucha pomysłów uczniów i odważnie patrzy im w oczy. Pyta o ich ocenę ujęcia prezentowanego tematu, skuteczności zaproponowanej metody, atrakcyjności zadań, powodów trudności w ich podjęciu. Informacje od nich uzyskane stają się tym samym istotną przesłanką do doskonalenia wspólnej pracy.

Trzecią rolą nauczyciela jest ta mało wdzięczna, choć najbardziej rozpowszechniona w systemie szkolnym, bo wiąże się z kontrolą wiedzy i umiejętności uczniów. Jednak i na tym poziomie metafora supermarketu może pomóc w przedefiniowaniu

${ }^{10}$ W. Okoń, dz. cyt., s. 44. 
nauczycielskich zadań. Chodzi o spojrzenie na obszar przygotowywania i przeprowadzania sprawdzenia kompetencji uczniów jako na swego rodzaju badanie „edukacyjnego pulsu” ucznia. To od tego badania zależy rozpoznanie sytuacji i przyjęcie określonej, dalszej strategii pracy. Z tą rolą wiąże się opracowanie różnorodnych form sprawdzania wiedzy, nadawanie im określonego znaczenia w toku całego procesu nauczania, a także przygotowanie adekwatnej, pełnej informacji zwrotnej, która ma pomóc uczniowi zweryfikować dotychczasową pracę własną oraz określić jej mocne i słabe strony.

Zatem w dydaktycznym procesie elementem kluczowym jest zbudowanie interesującej i różnorodnej oferty edukacyjnej, przy czym poziom jej atrakcyjności winien przewidywać możliwy sposób jego odbioru przez ucznia. I nie chodzi tu o banalizowanie treści czy metod pracy z młodzieżą, by trafić do każdego i przypodobać się najbardziej opornym i niezaangażowanym. Mam na myśli takie konstruowanie przez nauczyciela procesu, by dawał on jak najszerszy wybór obszarów czy metod pracy, z których może skorzystać jego wychowanek. To ważny aspekt relacji między pedagogiem i uczniem. W każdym z omówionych wymiarów, choć nastolatek ma być postacią kluczową lekcyjnego universum, to jednak nauczyciel w tak zarysowanej przestrzeni edukacyjnej jest jej twórcą i animatorem. I to on winien szybko interpretować postawę uczącego się, wiedzieć, czy ten jest zaintrygowany czy znudzony proponowanymi wyzwaniami oraz reagować na ów stan. Wagę stałej obserwacji uczniów podkreślał wielokrotnie S. Hessen, bowiem wtedy można prześledzić jak myślą uczniowie, „jak formułują zagadnienia, jak odrzucają proponowane rozwiązania, jak sami rozwiązują zagadnienia i uzasadniają swoje rozwiązania, czy wreszcie jak wykorzystują wyniki swych własnych dociekań w pracy poznawczej”"1.

Z drugiej strony kreowanie edukacyjnych procesów wymaga szczególnego podejścia do budowania zadań, które mają nie tylko umożliwiać poznanie konkretnych treści przedmiotowych czy umiejętności z nimi związanych, ale stymulować uczenie się ucznia, a to wymaga zaangażowania i głębszego przetwarzania informacji. A proces ten przebiega - jak pisze Manfred Spitzer - zarówno w samotności, jak w społeczności i zawsze jest ściśle powiązany z ciekawością i radościąa ${ }^{12}$. Rozwiązaniem, które sprawdza się w pracy, jest spojrzenie na jednostkę 45-90 minut jako ogniwo pewnego cyklu działań, a nie zamkniętą skończoną całość. Dlatego warto zobaczyć własne lekcje i wszelkie działania z nimi związane jako metaforyczny „szwedzki stół”, w którym rolą nauczyciela jest sute jego zastawienie, a zadaniem ucznia korzystanie z tego nakrycia w określonym czasie ${ }^{13}$. Jeśli uczeń odmawia - podejmuje pewną de-

11 Tamże.

12 M. Spitzer, Jak uczy się mózg, Wydawnictwo Naukowe PWN, Warszawa 2012, s. 290.

13 Ta inspirująca i jakże trafna analogia pochodzi z listu przesłanego do redakcji jednej z gazet, którego nadawcą jest nauczyciel akademicki opisujący swoje zmagania ze studentami: http://wyborcza.pl/1,95891,12391237,Studia to rodzaj szwedzkiego stolu Niektorzy nie.html (dostęp: 27.04.2018). 
cyzję i wybiera stan braku, nienasycenia. W efekcie musi się zmierzyć z konsekwencjami, bo po zamknięciu „kuchni” nic już nie dostanie. Procentuje tu świadome stwarzanie odbiorcom różnorodnych możliwości działania, takich jak: uczenie pracy z celami i kryteriami sukcesu, notowania, zarówno liniowego, jak i wizualnego ${ }^{14} \mathrm{czy}$ graficznego ${ }^{15}$, współpraca przy pomocy metody portfolio, w którym widać efekty doskonalenia notatek i budowania przez młodzież zindywidualizowanych pomocy naukowych oraz strategii własnej pracy, przygotowanie autorskich testów, które oswajają z formułą egzaminu maturalnego, co pozwala je wzbogacić o elementy, których na zewnętrznych egzaminach brakuje. Pomocne i bardzo angażujące są sprawdziany w formie krótkich kartkówek, które uczniowie nawzajem sobie sprawdzają i formułują informację zwrotną, motywując siebie do pracy i sprawdzając swoje przygotowanie, ciekawe i frapujące tematy esejów (wypracowań) - nieliczne mogą być obligatoryjne, inne tylko dla tych, którzy chcą pisać16. Poszerzanie horyzontów i obszarów uczniowskich poszukiwań może rozwijać się za pośrednictwem poczty elektronicznej, dzięki której uczniowie otrzymują dodatkowe materiały do lekcji ${ }^{17}$, linki do wartościowych i ciekawych źródeł dostępnych w sieci. Nieocenionym medium i pomocą dydaktyczną stają się autorskie prezentacje multimedialne, wokół których buduje się lekcje wraz z różnorodnymi formami dzielenia się wiedzą, tj.: wykłady, dyskusje, ćwiczenia, warsztaty, tworzenie posterów, moodboardów, pytania (zadania) otwarte. Nie bez znaczenia w procesie rozwoju osobowości i kompetencji społecznych uczniów jest stwarzanie okazji do pracy o charakterze projektowym przy samodzielnym przygotowaniu referatów i prezentacji wizualnych do wygłoszenia na forum, po których uczniowie otrzymują informację zwrotną - od nauczyciela i od swoich kolegów. Bardzo wartościowym elementem lekcji są audycje na podkastach, a także fragmenty filmów fabularnych, przy których uczniowie podzieleni na grupy wychwytują określone informacje, którymi dzielą się w czasie omawiania filmu po jego projekcji. W tryb budowania procesu nauczania - uczenia się warto włączyć przygotowanie uczniów do przedmiotowej olimpiady artystycznej, traktując ją z jednej strony jako rodzaj diagnozy rozległości wiedzy uczniów, z drugiej - jako czynnik mobilizujący i ukierunkowujący tych najbardziej ambitnych do dodatkowej pracy oraz pomocny w poznaniu własnych reakcji w sytuacji egzaminacyjnej.

${ }^{14}$ W. Pillars, Visual note-taking for educators. A teacher's guide to creativity, W.W. Norton \& Company, New York-London, 2016; N. Roßa, Sketchnotes. Visuelle notizen für Alles, Frechverlag GmbH, Stuttgart 2017.

${ }^{15}$ G. Petty, Nowoczesne nauczanie. Praktyczne wskazówki i techniki dla nauczycieli, wykładowców i szkoleniowców, Gdańskie Wydawnictwo Psychologiczne, Sopot 2010, s. 346.

${ }^{16}$ M. Harmin, Duch klasy. Jak motywować uczniów do nauki?, CEO, Warszawa 2005, s. 82.

${ }_{17}$ Wykorzystanie potencjał Internetu - jak pisze Sławomir Sztobryn - z powodzeniem można wkomponować w pedagogikę Freineta, a w jej elastyczne ramy współpracownicy mają pełne prawo włożyć treść adekwatną do miejsca i warunków, w których przyszło im pracować. Por. S. Sztobryn, dz. cyt., s. 359. 
Jak widać, już ta podstawowa oferta dla uczniów jest bardzo różnorodna. Warto przy tym pamiętać, że zupełnie naturalnym zjawiskiem jest fakt, że nie ze wszystkich działań korzysta cała klasa. Poza tym każdy uczestnik do pewnego stopnia podejmuje się niektórych zadań we własnym tempie, za to w szerokich ramach, które jednak umożliwiają rozwój i wiążą się z budowaniem świadomości własnego procesu pracy. Fundamentalną sprawą dla młodego człowieka jest pielęgnowanie możliwości wyboru, ale i niekiedy akceptacja faktu jego reagowania na ostatnią chwilę, co często prowadzi do efektów słabszych niż oczekiwane. To dla nauczyciela jest zawsze bardzo trudne. Dlatego trzeba jak najczęściej stwarzać uczniom okazję do poddania się autorefleksji i przeanalizowania sposobu realizacji danego zadania, co najczęściej prowadzi do ciekawych wniosków na przyszłość, a nierzadko pomaga uniknąć kolejnych błędów w zaplanowaniu pracy własnej.

Wśród naszych uczniów są tacy, którzy preferują wygodną pasywność i bierne dryfowanie z głównym nurtem przetrwania, inni wybierają reprodukcję zamiast interpretacji, jeszcze inni domagają się zamkniętej wiedzy, którą przyswoją i zaliczą. Są też jednostki poszukujące, dociekliwe, choć tych niestety nie widać w pierwszym szeregu i nie zawsze stają się dla kolegów inspiracją do pracy. Pozwalają się odkrywać stopniowo, w miarę oswajania szkolnego otoczenia i głębszego wchodzenia w przygotowane lekcje. W zbudowanej, jak opisana wyżej przestrzeni edukacyjnej, w tych szczelinach wolności - mimo sztywnych ram szkolnego systemu - to de facto uczeń jest głównym aktorem, dodajmy, aktorem uczestniczącym, aktywnym na wielu obszarach. Takim, który coraz częściej wychodzi ze strefy swego komfortu i podejmuje decyzję o uczestnictwie lub wycofaniu się, najczęściej świadomy konsekwencji każdego z wyborów. I to też należy potraktować jako podjęcie decyzji, którą nauczyciel-kreator procesu winien uszanować.

\section{Rozwiązania praktyczne}

W ramach dość schematycznej struktury, jaką jest organizacja szkolna, z całą pewnością można i trzeba projektować zadania na tyle różnorodne, by stały się dla odbiorców frapującymi wyzwaniami edukacyjnymi od strony merytorycznej oraz przyczyniały się do rozwoju osobowości ucznia i jego samoświadomości. Mam na myśli sytuacje dydaktyczne, które pozwalają nauczycielowi pełnić role opisane na początku niniejszego artykułu, uczniowi natomiast umożliwią dokonywanie wyborów i doświadczenie ich konsekwencji, co prowadzi do przejęcia kontroli nad własnym procesem uczenia się.

$\mathrm{W}$ ten paradygmat, zainspirowany metaforą supermarketu, wpisują się działania, jakie podjęto w jednej z wielkopolskich szkół artystycznych. Niektóre z nich są już zamknięte, choć wypracowane dzięki nim rozwiązania służą w pracy z kolejnymi grupami młodych adeptów sztuki, inne natomiast organizowane są nieprzerwanie.

Inicjatywą, od której warto zacząć pracę z uczniami w klasach pierwszych szkoły średniej, są warsztaty pt. „Uczeń bierny - uczeń aktywny”. Uczestnicy pracują wów- 
czas z matrycą Eisenhowera i dokonują wyboru „swojej” ćwiartki, poznając zarazem style działania różnych ludzi. Dowiadują się o sposobach myślenia i podejścia do zadań uczniów proaktywnych i reaktywnych. Równocześnie poddają refleksji własne strategie pracy. W finale zajęć muszą też podjąć decyzję, w której wyznaczonej części sali lekcyjnej stanąć - czy po stronie uczniów aktywnych, czy biernych. Nierzadko to rozstrzygnięcie wiąże się z pewnym wyzwaniem, bowiem wybór możliwości jest mocno spolaryzowany. To działanie jest celowe, wyostrza bowiem myślenie krytyczne, a w danym momencie prowokuje młodych ludzi do autodiagnozy i doświadczenia określonych emocji. Nierzadko dodatkowym walorem ćwiczenia jest dyskusja, która wywiązuje się zwłaszcza w gronie uczniów niezdecydowanych czy sceptycznych - ci chętnie zostaliby pośrodku. Opisane działanie ma także walor poznawczy, bowiem nowi uczniowie klas pierwszych jeszcze niemal się nie znają, uważnie obserwują innych kolegów z grupy i budują sobie ich aktualny obraz. Nierzadko dyskusja wokół wyboru określonego miejsca przenosi się na korytarz, zajmuje przerwę, co jest dowodem silnego zaangażowania młodzieży w zaproponowane zadanie. Trzeba jednak podkreślić, że rozeznanie stanu wyjściowego, choć uproszczone, nie jest jedynym walorem tych zajęć. W dalszej części spotkania uczniowie mają stanąć po tej stronie, po której chcieliby się znaleźć, o ile miejsce pierwotnie wybrane im nie odpowiada. Mimo że klasy znacznie się różnią, co widać podczas wykonywania ćwiczenia, to jednak zdecydowana większość uczniów biernych nie jest zadowolona z obecnego stanu i pragnęłaby przejścia do grupy aktywnych, bo to oni najczęściej czerpią satysfakcję ze swojego sprawstwa, mają lepsze wyniki, a jednocześnie dostrzegają obszary do udoskonalenia.

Kolejnym działaniem w „supermarketowym” paradygmacie edukacyjnym, zaproponowanym w ramach omawianego zagadnienia może być innowacja pedagogiczna o charakterze programowo-metodycznym pt. „Osobowość przedmiotu”. Wdrożono ją w czasie trwania jednego roku szkolnego w formie ośmiu nieobowiązkowych, pozalekcyjnych spotkań organizowanych raz w miesiącu. Miały one charakter dobrowolny, przy czym przed zajęciami uczniowie pisemnie deklarowali swoje przybycie, dzięki czemu można było zaplanować odpowiednią ilość materiałów potrzebnych do pracy. Każde spotkanie poświęcono innemu dziełu sztuki, którego omawianie miało charakter wielogłosu pozwalającego zaprezentować różne interpretacje tego samego obiektu. Każdorazowo dzieło omawiane było z perspektywy historyka sztuki, które to spojrzenie wzbogacone zostało punktem widzenia zaproszonego gościa - specjalisty (artysty grafika, malarza, projektanta, rzeźbiarza, historyka, psychologa oraz architekta wnętrz), a także grupy uczestniczących w spotkaniu uczniów. Możliwość wyboru uczestnictwa w comiesięcznych zajęciach, które nigdy nie musiały być odwoływane z powodu braku zainteresowania, spowodowała pojawienie się zróżnicowanego grona odbiorców. Niekiedy uczniowie przychodzili cyklicznie, innym razem zjawiali się powodowani zainteresowaniem tematem, osobą współprowadzącego czy dziedziną sztuki (nauki), którą reprezentował. Praca przebiegała w oparciu o przygotowane 
przez prowadzącego filmy, teksty źródłowe, grafy i karty do uzupełnienia wraz z odsyłaczami do dodatkowych materiałów. Wszelkie notatki i otrzymane materiały wędrowały do uczniowskich skoroszytów, które - wpisując się w metodę portfolio - były narzędziem doskonalącym pracę własną ucznia, uczyły organizacji oraz personalizacji narzędzi uczenia się. Ponadto ich otwarta formuła pozwalała na wykorzystanie ich na innych przedmiotach związanych z poznawaniem kultury i sztuki.

W opinii odbiorców innowacji „Osobowość przedmiotu” ciekawym zadaniem, które zaplanowano na ostatnie zajęcia, było zaprezentowanie przez każdego uczestnika wybranego przez siebie przedmiotu o charakterze artystycznym. Prezentacja miała na celu pokazanie go z wielu perspektyw, wykorzystanie przez ucznia metod pracy wdrażanych na poprzednich spotkaniach oraz umożliwienie mu podzielenia się z innymi uczestnikami zajęć subiektywnymi kryteriami wyboru. Następnym krokiem było wspólne przygotowanie posteru, który stał się nie tylko wizualnym podsumowaniem innowacji, ale także okazją do wykorzystania potencjału plastycznego uczestników projektu.

Jak wielokrotnie podkreślano, beneficjenci wspomnianych w niniejszym artykule inicjatyw mieli wielokrotnie okazję wyrazić subiektywną ocenę zarówno przedmiotowych zjawisk czy dzieł sztuki, jak i własnego procesu pracy. Na kanwie tych rozważań niekiedy rodziły się uwagi pod adresem proponowanych aktywności, ich przeprowadzenia i pomysłów nauczyciela. Te stały się istotnym elementem informacji zwrotnej, jaka pozwala nauczycielowi rozwijać się i doskonalić swój warsztat pracy. Podkreślano wartość konfrontacji różnych punktów widzenia, szukanie korespondujących ze sobą dzieł - plastycznych i literackich, możliwość niczym niezakłóconego poznawania epok innych niż omawiane na lekcji w danym miejscu oświatowego harmonogramu oraz komfort uczenia się poza twardym rygorem szkolnego dzwonka. Szybkość i duże tempo realizacji codziennych zadań w szkole wyraźnie odbierane są, także przez uczniów, jako przeszkoda w efektywnej pracy. Trudno nie zgodzić się z Thomasem Hillardem Ericksenem, który uważa, że „pewne myśli mogą funkcjonować wyłącznie w trybie powolnym, a niektórymi drogami rozumowania podążać da się tylko w spójny i ciągły sposób, bez przerywania [...]"18. Innowacja pedagogiczna „Osobowość przedmiotu” miała również szansę uświadomić jej odbiorcom i beneficjentom, że element czasu jest niezmiernie istotny, żeby kogoś lub coś poznać. I nie ma tu znaczenia, czy chodzi o człowieka, czy o dzieło sztuki.

„Gra o sztukę. Edukatorium barokowe” było kolejnym projektem, który został zrealizowany - tym razem w ramach cotygodniowych lekcji historii sztuki z młodzieżą w klasie trzeciej liceum. I także on miał charakter innowacji pedagogicznej, która została opracowana na bazie wniosków płynących z neuronauk. To przedsięwzięcie również bazowało na koncepcji stworzenia uczniom szerokiego pola do aktywności oraz -

18 T.H. Ericksen, Tyrania chwili. Szybko i wolno płynacy czas w erze informacji, Państwowy Instytut Wydawniczy, Warszawa 2003, s. 162. 
tam, gdzie było to możliwe - zaoferowania im ich wyboru. Już na samym początku wspólnej z uczestnikami pracy zbudowany został system punktów przyznawanych im za wszelkie działania, tak lekcyjne, jak i pozalekcyjne, o ile wiązały się z przedmiotem nauki. To bardzo istotne posunięcie uczyniło z uczniów aktywnych współtwórców systemu, w jakim przyszło im pracować przez kolejne miesiące. Wiele uwagi poświęcono zbudowaniu katalogu różnorodnych działań dla uczniów oraz myśleniu w kategoriach pracy w perspektywie semestru, w tym zadań domowych do wyboru. Skupiono się też na budowaniu świadomości znaczenia pracy własnej ucznia, tej poza kadrem lekcyjnym. Dlatego też jednym z istotnych komponentów innowacji, a zarazem ważnym obszarem wspólnej pracy była zamknięta grupa na Facebooku, dla której publikowane były dodatkowe materiały audiowizualne, notatki, pliki z narzędziami do pracy, zadania do wykonania i ich efekty. Ponadto inicjowano tam dyskusje oraz zaproszenia do dzielenia się materiałami. Przez moment, tuż przed sprawdzianem, grupa stała się nawet platformą wsparcia dla uczennic przygotowujących się do tego zadania. Dzięki temu nauczyciel mógł odnotować, że w odniesieniu do ponad połowy klasy można było mówić o świadomym wejściu w proces samodzielnej nauki ${ }^{19}$.

Początek każdej cotygodniowej lekcji stawał się szybką intelektualną rozgrzewką i błyskawiczną rekapitulacją tego, co uczniom zapadło w pamięć po poprzednim spotkaniu. Dzięki neuronaukom wiadomo, że start dydaktycznych działań ma kluczowe znaczenie w procesie budowania efektywnej atmosfery pracy. Wykorzystanie wiedzy na temat neuronów lustrzanych, o których pisze Joachim Bauer, w opisywanych działaniach przynosiło bardzo dobre rezultaty. Pozytywne nastawienie nauczyciela, jego głos, zachęta, humor i życzliwość, za pomocą zjawiska odzwierciedlenia często doprowadzały do podobnej reakcji podopiecznych, tym samym pomagały im przełamać obawy przed aktywnym wejściem w zadania i dzieleniem się tym, co już wiedzą na dany temat ${ }^{20}$. Odpowiedzi i zaangażowanie uczniów dla nauczyciela stanowiło natychmiastową informację zwrotną na temat najbardziej atrakcyjnych fragmentów pracy w szkole lub własnych odkryć uczestników, bo te zazwyczaj zapamiętane były najmocniej ${ }^{21}$. Młodzież uczyła się w oparciu o materiały przygotowywane przez nauczyciela. Każde spotkanie lekcyjne było okolicznością do pracy indywidualnej, zespołowej ${ }^{22}$, w ciszy i na forum, wyboru rodzaju treści do opracowania, ćwiczenia notowania graficznego, wykonywania plakatów, komentowania ich oraz wspólnego oglądania przygotowanych filmów poświęconych szerokiemu, kontekstualnemu i formalnemu ujęciu słynnych dzieł i ich twórców. Niezmiernie ważnym rozwiązaniem stało się przygotowanie przez nauczyciela wizualnych kart do pracy nad tekstami źródłowymi czy filmami oraz nakreślenie kilku perspektyw ich oglądu, by dać

19 G. Petty, dz. cyt., s. 327.

20 J. Bauer, Empatia. Co potrafia neurony lustrzane?, Wydawnictwo Naukowe PWN, Warszawa 2015, s. 63.

${ }^{21}$ M. Harmin, dz. cyt., s. 27.

22 G. Petty, dz. cyt., s. 213. 
asumpt do wspólnej wymiany spostrzeżeń ${ }^{23}$, konfrontacji opracowanych materiałów i zainspirować uczniów do zastosowania myślenia wizualnego w procesie nauki. To wykorzystanie mocnych stron ucznia szkoły plastycznej, który swobodnie posługuje się rysunkiem i liternictwem, było okazją integrującą różne sposobów przyswajania wiadomości, ćwiczenia umiejętności selekcjonowania i syntetyzowania informacji oraz mocno angażowało uczestników zadania. Finalna dyskusja, której punkt wyjścia stanowiły wnioski z pracy i notatki wizualne, pozwalała na ponowne, głębokie przetwarzanie wiedzy oraz personalizowanie jej, a przez to lepsze jej zapamiętanie ${ }^{24}$. Niekiedy echa tych rozważań pojawiały się w zadaniach domowych czy we wpisach na facebookowej grupie. Proponowane uczniom ćwiczenia (np. wykonywanie memu dla barokowego człowieka), pomyślane były w taki sposób, aby wykorzystać poczucie humoru młodych ludzi i ośmielić ich do wypracowania osobistego stosunku do epoki baroku. Efekty tych prac bywały upubliczniane, nie tylko w wirtualnej grupie projektowej, ale również w wersji dostępnej w przestrzeni szkoły, dzięki temu uruchomiony został proces „oswajania” omawianych zagadnień, które przez swą złożoność i bogactwo mogłyby onieśmielać.

Jedną z aktywności przypadającą na koniec tej kilkumiesięcznej innowacji były podsumowujące epokę sprawdziany, których nie można było pominąć, co zrozumiałe w istniejącym systemie szkolnym. Jednak za najlepsze zwieńczenie przedsięwzięcia uznać należy jednodniowy ogólnoszkolny projekt „Barokowy supermarket”. To on najpełniej wpisał się w paradygmat wspierania uczniowskich wyborów i dał wyraz idei postulowanej przez Celestyna Freineta, która dla wielu w szkolnej rzeczywistości jest nadal rodzajem luksusu - swobody uczniowskiego wyboru i podążania za swymi zainteresowaniami. Być może ta możliwość selekcji treści i metod pracy w „Grze o sztukę” może wydawać się znacznie ograniczona, lecz nie można zaprzeczyć jej istnieniu. Poza tym, jak uważa Gordon Mathews, „nie jesteśmy niewolnikami otaczającego świata, lecz mamy (w sensie społecznym, jeśli nie filozoficznym) pewien stopień wolności wyboru tego, kim jesteśmy"25. Warto dodać: kim jesteśmy i jak pracujemy.

Po wcześniejszej kilkutygodniowej diagnozie potrzeb i zainteresowań społeczności szkolnej powstał swego rodzaju „asortyment” w barokowym supermarkecie, obejmujący trzygodzinny blok symultanicznych warsztatów, z których każdy trwał 30 minut i dedykowany był innej dziedzinie nauki wiążącej się z omawianą epoką. Zaproponowano uczniom do wyboru udział w ćwiczeniach z historii sztuki, matematyki, fizyki, języka angielskiego, historii i projektowania przestrzennego. Niektóre zajęcia zostały powtórzone dwukrotnie ze względu na duże zainteresowanie uczniów. Uczestnicy wpisali się w konwencję „programu lojalnościowego” inspirowanego systemem pozyskiwania klientów przez ogólnoświatowe sieci sklepów i otrzymali wejściówki do zbierania stempli od nauczycieli prowadzących spotkania. Trzy pieczątki za udział w zaję-

\footnotetext{
23 M. Harmin, dz. cyt., s. 44.

24 G. Petty, dz. cyt., s. 205.

25 G. Mathews, dz. cyt., s. 45.
} 
ciach uprawniały do wzięcia udziału w loterii z nagrodą. Losowanie natomiast stało się okazją do podsumowania projektu i uzyskania od uczniów ankiet zwrotnych na temat pojedynczych warsztatów i projektu jako całości. W rzeczy samej, cytując Mathewsa, „nie można [...] powiedzieć, że w supermarkecie kultury nie ma miejsca na indywidualne wybory” ${ }^{26}$, tak też w projekcie „Barokowy supermarket” to uczniowie decydowali, w jakich trzech spośród pięciu spotkań wezmą aktywny udział.

\section{Podsumowanie - ku wielostronności kształcenia}

Jak wykazano na przykładzie zrealizowanych działań, metafora supermarketu jest bardzo dobrym odniesieniem dla edukacyjnych przedsięwzięć. Rodzi przy tym napięcia, co wydaje się oczywiste, gdy nieszablonowa propozycja rości sobie prawo zaistnienia w schemacie organizacji szkolnej. Jednak mimo przeciwności, skutecznie inspiruje zarówno nauczyciela-kreatora procesu uczenia się, jak i jego współtwórcę, czyli ucznia. Ośmiela swoją atrakcyjnością i dostępnością, czasem wprowadza humor i kolorowy wielogłos liter, znaków, dźwięków i obrazów, pozwalając na artykułowanie własnych opinii, ujawnianie osobistych reakcji na temat prezentowanych treści przedmiotowych. Uczeń ma poczucie, że choć w kadrze szkolnym zdecydowaną większość zadań mu się narzuca, to stworzenie przestrzeni do własnych wyborów nie jest utopią, ale może z powodzeniem zaistnieć w ramach cyklu zajęć lekcyjnych czy pozalekcyjnych. Różnorodność oferty, jaką opracowuje nauczyciel dla swoich podopiecznych, choć jest owocem czasochłonnego procesu przygotowań, to z całą pewnością wpisuje się w ścieżkę budowania nowej kultury pracy, zrywa z rutyną „przerabiania” kolejnych tematów i stawia na wzmacnianie uczniowskiej odpowiedzialności za własny rozwój. Nastoletniemu uczestnikowi tej drogi pozwala na dokonywanie osobistych wyborów, eksperymentowanie z określonymi modelami zachowań, zaniechań i mierzenie się z ich konsekwencjami. Zrealizowane działania stają się próbą konkretyzacji ideału kształcenia wielostronnego, koncepcji zaproponowanej przez Wincentego Okonia w drugiej połowie lat 60. XX wieku - tym bardziej aktualnej, bo wzbogaconej wnioskami płynącymi z badań nad mózgiem.

Rozważając proces przenikania nowatorskich postaw do zbiorowej świadomości, Caroline Levine przywołuje figurę pętli zwrotnej, która uświadamia mechanizm stawania się znajomym tego, co jeszcze do niedawna było obce. „Tak samo jak szokująca sztuka awangardy potrafi w kilka dekad stać się gładkim mainstreamem (jak malarstwo impresjonistyczne czy montaż filmowy), innowacje intelektualne przedostają się stopniowo do kultury masowej i mogą nawet przerodzić się w coś na kształt drugiej natury mas"27. Można zatem spodziewać się podobnego stanu rzeczy w odniesieniu do nowatorskich działań, o których była mowa. Opisane innowacje i projekty - ów

\footnotetext{
26 Tamże.

${ }^{27}$ C. Levine, dz. cyt., s. 294.
} 
„szkolny supermarket” - były nade wszystko okazją do głębszego sp otkania zainteresowanych stron, do wymiany doświadczeń, do nawiązania dialogu z bohaterami dziejów sztuki, jak i ze sobą. Dla wszystkich zainteresowanych stały się niecodzienną przestrzenią twórczej aktywności i doskonalenia procesu uczenia/nauczania. Ale to od uczestników i „klientów edukacyjnego supermarketu” zależy, czy docenią komfort posiadania wyboru czy też wybiorą komfort i biernie poddadzą się przewidywalnemu nurtowi szkolnego życia, w którym niewiele od nich zależy.

\section{Bibliografia}

Arp R. (red.), 1001 idei, które odmieniły nasz sposób myślenia, Elipsa Publicat S.A., Poznań 2013.

Bauer J., Empatia. Co potrafia neurony lustrzane?, Wydawnictwo Naukowe PWN, Warszawa 2015.

Ericksen T.H., Tyrania chwili. Szybko i wolno płynący czas w erze informacji, Państwowy Instytut Wydawniczy, Warszawa 2003.

Harmin M., Duch klasy. Jak motywować uczniów do nauki?, CEO, Warszawa 2005.

Kostyło H., Podwójny pozór w edukacji na przykładzie koncepcji Paula Freire’a, [w:] M. Dudzikowa, K. Knasiecka-Falbierska (red.), Sprawcy i/lub ofiary działań pozornych w edukacji szkolnej, Oficyna Wydawnicza Impuls, Kraków 2013.

Levine C., Od prowokacji do demokracji. Czyli o tym, dlaczego potrzebna nam sztuka, Warszawskie Wydawnictwo Literackie Muza SA, Warszawa 2013.

Mathews G., Supermarket kultury, Państwowy Instytut Wydawniczy, Warszawa 2005.

Okoń W., Wprowadzenie do dydaktyki ogólnej, Wydawnictwo Akademickie „Żak”, Warszawa 2003.

Petty G., Nowoczesne nauczanie. Praktyczne wskazówki i techniki dla nauczycieli, wykładowców i szkoleniowców, Gdańskie Wydawnictwo Psychologiczne, Sopot 2010.

Pillars W., Visual note-taking for educators. A teacher's guide to creativity, W.W. Norton \& Company, New York-London, 2016.

Roßa N., Sketchnotes. Visuelle notizen für Alles, Frechverlag GmbH, Stuttgart 2017.

Sztobryn S., Pedagogika Celestyna Freineta, [w:] Z. Kwieciński, B. Śliwerski (red.), Pedagogika, t. 1, Wydawnictwo Naukowe PWN, Warszawa 2014.

Spitzer M., Jak uczy się mózg, Wydawnictwo Naukowe PWN, Warszawa 2012.

Studia to rodzaj szwedzkiego stołu. Niektórzy nie biora nic, a potem narzekają, że sa głodni, http://wyborcza.pl/1,95891,12391237,Studia to rodzaj szwedzkiego stolu Niektorzy nie.html (dostęp: 27.04.2018).

Szuman S., O sztuce i wychowaniu estetycznym, Państwowe Zakłady Wydawnictw Szkolnych, Warszawa 1969. 


\section{The comfort of choice or the choice of comfort? On educational strategies in a school of fine arts (based on the author's own teaching experiences)}

Abstract: One of the metaphors of the modern world is the supermarket metaphor. On the one hand, a supermarket is synonymous the lesser quality. On the other hand, a supermarket brings with it the comfort of choice. The supermarket as a space for choice should be inspirational for education. I'm talking about construction, by the teacher, of a process that would allow the pupil real choice of areas or methods of work. The teacher still plays the key role in this scenario, but as an idea-giver and animator of attractive tasks, from which the pupil chooses those most appealing to him/her. And it is the pupil who is de facto the main actor in this process. The enterprises I developed and put into practice at the Liceum Plastyczne (High School of Fine Arts) in Poznan fit into such a supermarket paradigm. These were: "Passive pupil - active pupil" workshops, the pegadogical innovation "Personility of a subject", and also "Baroque supermarket" project activities which completed another pedagogical innovation - "Playing for Art".

Keywords: artistic education, pedagogical innovations, art, teaching, history of art

\footnotetext{
About the author: Karolina Prymas-Jóźwiak - Master's degree in the history of arts, certified teacher, educator, coach, completed postgraduate studies in the Knowledge of Culture, "Akademia Trenera" ("Coach Academy") and Educational Neuroscience. Practitioner of design thinking and visual thinking in education. Author of pedagogical innovations: "Osobowość przedmiotu” (“Subject Identity”) and „Gra o sztukę. Educatorium barokowe" ("The Game of Arts. Baroque Educatorium”). Initiator and coordinator of educational projects. Member of the Association of Art Historians. Her research interests include teaching the history of art, artistic education, learning-teaching methodology, the pedagogy of creativity.
} 


\title{
Formy wsparcia rodziny w ramach projektów unijnych. Praca systemowa z rodziną w opinii specjalistów
}

\begin{abstract}
Streszczenie: W niniejszym opracowaniu autorka przedstawia - jako przykład dobrych praktyk - formy pracy z rodziną w ramach projektu „By-PAS Bytomska Pracownia Aktywności Społecznej”. Analizie zostały poddane rodzaje działań skierowane do rodzin z grupy ryzyka, w oparciu o amerykański zintegrowany model usług „cztery kręgi wsparcia”, a także zakres kompetencji poszczególnych specjalistów pracujących z rodziną. W projektowaniu pracy z rodzinami dysfunkcyjnymi zwrócono uwagę na potrzebę oddziaływań na trzech poziomach wsparcia: profilaktyki, interwencji oraz integracji przy równoczesnym organizowaniu społeczności lokalnej.
\end{abstract}

Słowa kluczowe: projekt unijny, rodzina dysfunkcyjna, organizowanie społeczności lokalnej, kultura ubóstwa, pomoc społeczna

\section{Wstęp}

Niewątpliwie jednym $\mathrm{z}$ istotnych atutów realizacji projektów unijnych jest to, że w stosunkowo krótkim czasie można wypracować standardy pracy, które po zakończonym programie mogą zostać wdrożone w organizację. Na podstawie analizy przeprowadzonej przez J. Hrynkiewicza, dotyczącej jakości metamorfoz zachodzących w pomocy społecznej, w latach 2004-2011 wprowadzono najwięcej zmian w polityce

\footnotetext{
* Kinga Konieczny - pedagog, specjalista pracy z rodziną w Miejskim Ośrodku Pomocy Rodzinie w Bytomiu, doktorantka w Zakładzie Pedagogiki Ogólnej i Metodologii Badań w Wydziale Etnologii i Nauk o Edukacji, Uniwersytet Śląski w Cieszynie. Obszar zainteresowań naukowych dotyczy pedagogiki opiekuńczo-wychowawczej (znaczenie organizacji pozarządowych we wspieraniu rodzin problemowych), pedagogiki resocjalizacyjnej oraz edukacji dzieci pochodzących $\mathrm{z}$ rodzin dysfunkcyjnych.
} 
społecznej i aktywnej integracji ${ }^{1}$. Program Operacyjny Kapitał Ludzki finansowany ze środków Europejskiego Funduszu Społecznego na nowo zdefiniował rolę integracji społecznej i zrewolucjonizował system pomocy społecznej. Przede wszystkim, zmiana wiązała się z nawiązaniem współpracy z innymi instytucjami pomocowymi na poczet holistycznego włączania się osób i rodzin z grupy ryzyka w życie społeczne i zastosowania instrumentów o charakterze społecznym, zawodowym, zatrudnieniowym oraz zdrowotnym. Ponadto, innowacja aktywnej integracji, narzuciła na uczestnika podwójną rolę: usługobiorcy oraz partnera.

Na podstawie dokumentu „Zasady przygotowania, realizacji i rozliczania projektów systemowych Ośrodków Pomocy Społecznej, Powiatowych Centrów Pomocy Rodzinie oraz Regionalnego Ośrodka Polityki Społecznej w ramach Programu Operacyjnego Kapitał Ludzki 2007-2013"2 wprowadzono w instytucjach zindywidualizowany pakiet pomocy dla wszystkich klientów. Ośrodki otrzymały zatem możliwość wychodzenia poza sztywne schematy, a także okazję do eksperymentowania w metodyce prowadzenia pracy $\mathrm{z}$ rodzinami dysfunkcyjnymi.

\section{Rodzina jako podsystem społeczny}

Problematyka zabezpieczenia rodziny w dobie współczesnych przemian społeczno-gospodarczych staje się coraz częściej przedmiotem interdyscyplinarnych dyskusji. W systemowej teorii rodziny, rodzina jest systemem społecznym posiadającym jasno określone granice, podatnym na oddziaływanie środowiska, równocześnie na to środowisko wpływając ${ }^{3}$. Aktualnie coraz częściej mówi się o upadku, kryzysie rodziny. Socjologowie interpretują zjawisko za pomocą czterech koncepcji, w których podmiotem wspólnym są zmiany zachodzące we współczesnym świecie w kwestii władzy, moralności, ekonomii oraz obyczajowości. Według interpretacji funkcjonalistycznej do upośledzenia roli rodziny doszło przede wszystkim z powodu przejęcia przez instytucje państwowe większości jej funkcji, zwłaszcza opiekuńczo-wychowawczej. Definicja rodziny w danej koncepcji jest utożsamiana z grupą, w której członkowie mieszkają, funkcjonują w jednym gospodarstwie, dzielą się między sobą zdobytymi zasobami. Istnieją między nimi więzi pokrewieństwa, a relacje oparte są na zasadzie zależności. W koncepcji konserwatywnej kryzys rodziny wiąże się z upadkiem autorytetów moralnych, osłabieniem norm religijnych oraz polityką państwa skierowaną do matek samotnie wychowujących dzieci. Interpretacja liberalna jako powód dezin-

\footnotetext{
${ }^{1}$ J. Hrynkiewicz, Zakres, kierunki zmian w pomocy społecznej, [w:] M. Rymsza (red.), Reformy społeczne - bilans dekady, Wydział Nauk Społeczno-Pedagogicznych Wyższej Szkoły Pedagogicznej, Warszawa 2001, s. 97.

${ }^{2}$ www.efs.2007-2013.gov.pl/dokumenty/zmianywdokumentach/documents/zasady 7 1 2015.pdf (dostęp: 6.06.2017).

${ }^{3}$ Sz. Chrząstowski, Nie tylko schemat. Praktyka systemowej terapii rodzin, Wydawnictwo „Paradygmat", Warszawa 2014, s. 30-32.
} 
tegracji rodziny upatruje gwałtowny rozwój techniki, przeobrażeń ekonomicznych oraz zmian na rynku pracy. Natomiast koncepcja liberalna feministyczna osłabienie rodziny łączy z brakiem kooperacji w społeczeństwie, we wspólnotach i rodzinie nuklearnej, gdzie zmęczeni, zapracowani rodzice nie są w stanie otoczyć dzieci właściwą opieką ${ }^{4}$.

Współcześnie zatem stykamy się u rodzin, które dotychczas funkcjonowały prawidłowo, z rozluźnieniem więzi, odchodzeniem od rodzicielskich autorytetów, kryzysem wartości, próbą zdefiniowania własnej tożsamości. Niewątpliwie opracowanie „programów naprawczych” dla danego zjawiska stanowi wyzwanie dla psychologów, pedagogów, socjologów, filozofów. Jednak doświadczenia pracy socjalnej z rodziną w kryzysie dostarczają metod i sposobów pracy, a przede wszystkim mocno akcentują wzajemne korelacje i cyrkularność rodziny z otaczającym ją środowiskiem.

Amerykańscy badacze David A. Berns i Tery Long na podstawie analizy działań pomocy społecznej funkcjonującej w Stanach Zjednoczonych stworzyli koncepcję „Czterech kręgów wsparcia”, doprowadzając do przeorganizowania systemu wsparcia rodziny, korzystającej z instytucjonalnych form pomocy. Zdaniem badaczy długotrwała pomoc, którą oferuje państwo, doprowadza rodziny do uzależnienia od instytucji, osłabia motywację do wprowadzania jakichkolwiek zmian, a także utrwala bezradność i stagnację. W modelu „cztery kręgi wsparcia”, naukowcy, w graficznej formie odzwierciedlającej nakładające się na siebie koła, w centralnym miejscu umieścili rodzinę, następnie: sąsiedztwo i społeczeństwo, lokalny rynek i infrastrukturę, usługi kwalifikowane wysokością dochodu oraz interwencję inwazyjną ${ }^{5}$. Zintegrowany model usług „cztery kręgi wsparcia” wobec pracy z rodziną akcentuje przede wszystkim potrzebę umocnienia najbliższych kręgów znajdujących się obok rodziny (czyli społeczności) jako warstwy programu prewencyjnego, a także włączenia jej w procedurę wspólnego planowania działań. Pozwala to w głównej mierze na ograniczenie przepływu środków finansowych w postaci świadczeń pieniężnych (zasiłków) na rzecz rodziny, tym samym pobudzając ją do przyjęcia odpowiedzialności za swój rozwój w środowisku lokalnym oraz projektowania zmian w kontekście prawidłowego realizowania socjalizacyjnej, wychowawczej oraz stratyfikacyjnej funkcji rodziny. Przedefiniowanie celów, roli, form wsparcia pomocy społecznej wobec powyższego modelu koresponduje $\mathrm{z}$ niwelowaniem doraźnych świadczeń finansowych, które są najwyższe w kręgach interwencyjnych (np. odpłatność za umieszczenie dziecka w systemie pieczy zastępczej, zabezpieczenie infrastruktury sądów dla nieletnich, zakładów karnych) na rzecz wykorzystywania koncepcji organizowania społeczności lokalnej.

${ }^{4}$ T. Szlendak, Socjologia rodziny. Ewolucja, historia, zróżnicowanie, Wydawnictwo Naukowe PWN, Warszawa 2011, s. 377-383.

${ }^{5}$ B. Szatkowski, Instrumenty wsparcia rodziny - ujęcie porównawcze rozwiązań przyjętych w Polsce i USA, „Państwo i Społeczeństwo”, nr 3/2013, s. 93. 


\section{„By-PAS, czyli Bytomska Pracownia Aktywności Społecznej”}

Bytom należy do jednych z najbardziej problemowych miast w Europie ${ }^{6}$. Kryzys gospodarczy związany z powolnym upadkiem przemysłu od lat 90 . XX w. przyczynił się do zwiększenia zmarginalizowanych środowisk, wzrostu patologizacji życia społecznego oraz anomii społecznej. W nawiązaniu do procesu kulturowego dziedziczenia biedy, powiększania się enklaw ubóstwa mieszkańców Bytomia, polityka społeczna miasta w głównej mierze skoncentrowana jest wokół działań opierających się na wzmacnianiu zasobów rodzinny i ich stopniowej aktywizacji społeczno-zawodowej. Z pomocą środków finansowych z programów unijnych, poszczególne działania pomocowe zostały wzmocnione o innowacyjne narzędzia. Wnikliwej analizie również w ramach projektów poddano zadania pracowników pomocy społecznej, w tym asystentów rodziny i koordynatorów pieczy zastępczej.

Artykuł stanowi wynik analizy projektu „By-PAS Bytomska Pracownia Aktywności Społecznej”, realizowanego od listopada 2015 r. do końca grudnia 2017 r. jako przykładu dobrych praktyk związanych z programowaniem pracy systemowej z rodziną problemową, w której istnieje zagrożenie lub już wystąpiło zjawisko umieszczania dzieci w pieczy zastępczej. Projekt „By-PAS Bytomska Pracownia Aktywności Społecznej” prowadzony przez Fundację „Inicjatywa” w partnerstwie z Miejskim Ośrodkiem Pomocy Rodzinie w Bytomiu, skierowany jest do 582 mieszkańców, korzystających ze wsparcia ośrodka.

Koncepcja zadań prowadzonych w ramach projektu została oparta o wspomniany konstrukt teoretyczny - zintegrowany model usług „cztery kręgi wsparcia” (sąsiedztwo i społeczność, lokalny rynek i infrastrukturę, usługi kwalifikowane wysokością dochodu oraz interwencję inwazyjną), koncentrujący się wokół oddziaływań na rzecz rodziny wobec jej aktywnego zaangażowania w wszechstronny rozwój z założeniem, iż rodzina jako podsystem społeczny z jednej strony wpływa na najbliższe otoczenie, z drugiej zaś obserwuje, naśladuje i powiela tradycje, język, system wartości społeczności lokalnej. Priorytetowym celem projektu jest podniesienie poziomu integracji społecznej i aktywizacji zawodowej przy wykorzystaniu metod i narzędzi związanych z pracą socjalną, aktywną integracją oraz organizowaniem społeczności lokalnej w najbardziej wewnętrznym kręgu wsparcia, czyli w „sąsiedztwie i społeczności”.

Głównym problemem, wokół którego koncentruję się w niniejszym opracowaniu, to pytanie: „W jaki sposób specjaliści pracujący $\mathrm{z}$ rodziną mogą ją umacniać i pomagać jej w wypełnianiu podstawowych funkcji wychowawczych $w$ ramach projektów unijnych?”.

W przeprowadzonych badaniach posłużyłam się metodą sondażu diagnostycznego (technika wywiadu swobodnego) oraz metodą obserwacji uczestniczącej.

\footnotetext{
${ }^{6}$ www.bytom.pl/obszar-strategicznej-interwencji (dostęp: 6.06.2017).
} 
Czynnie uczestniczyłam w działaniach projektowych, prowadząc dla uczestników programu warsztaty rodzicielskie oraz konsultacje indywidualne. W okresie od sierpnia 2016 r. do marca 2017 r. przeprowadziłam warsztaty dla 72 osób, pochodzących z rodzin dysfunkcyjnych, o niskim statusie społecznym, z rodzin o skumulowanych czynnikach patogennych, w tym 18 osób korzystało ze wsparcia asystenta rodziny. Z indywidualnych konsultacji skorzystało 11 osób w trakcie 36 spotkań. Stale również znajdowałam się w kontakcie z pracownikami socjalnymi, asystentami rodziny, psychologiem oraz osobami z działu projektowego (łącznie 21 osób), z którymi przeprowadzałam wywiady.

Pomimo iż projekt ma na celu głównie osiąganie wskaźników efektywności społeczno-zatrudnieniowej, w artykule koncentruję się na przedstawieniu działań Miejskiego Ośrodka Pomocy Rodzinie w Bytomiu, związanych ze wspieraniem rodzin znajdujących się w różnych kryzysach, uwzględniając pomoc pozafinansową.

W kulturze ubóstwa, z której wywodzi się znaczna większość uczestników projektu, rodzina nie stanowi zwartej struktury o stabilnych korzeniach, pozycje rodziców nierzadko są osłabione ze względu na bezrobocie, alkoholizm, a dzieci dotyka zjawisko parentyfikacji ${ }^{7}$. Z wywiadów przeprowadzonych wśród pracowników zatrudnionych w ramach projektu wynika, iż z rodzinami z obszaru ryzyka (rodziny jeszcze wydolne wychowawczo, niewydolne wychowawczo, patologiczne) powinno pracować się na 3 poziomach wsparcia: profilaktyki, interwencji oraz integracji. Poziom profilaktyki skorelowany jest ze wskazaniem możliwości skorzystania ze wsparcia specjalistycznego, wzmacnianiem zasobów rodziny w zakresie umiejętności opiekuńczo-wychowawczych, czy też zdolności do prowadzenia gospodarstwa domowego w celu utrzymania dziecka w rodzinie. Włączanie w rodzinę usług asystenta rodziny, podejmowanie działań w obrębie redukcji szkód, przygotowanie rodziny na umieszczenie dziecka w pieczy zastępczej związane jest z realizacją wsparcia na poziomie interwencji, mając na względzie zabezpieczenie potrzeb dziecka. Praca z rodzicami i dzieckiem na rzecz jego powrotu do rodziny biologicznej oraz wzmacnianie kręgu otoczenia lokalnego wiąże się z realizacją trzeciego poziomu wsparcia integracji.

Przy realizacji zadań ze strony Miejskiego Ośrodka Pomocy Rodzinie zatrudnionych jest 16 pracowników socjalnych, pracujących stale z 20 środowiskami, 6 asystentów rodziny, 2 specjalistów pracy z rodziną, psycholog oraz prawnik, którzy współpracują z rodziną, jej poszczególnymi członkami oraz społecznością lokalną uczestników projektu (praca systemowa).

Liczba środowisk, z którymi współpracuje pracownik socjalny w zakresie realizowania zadania Praca socjalna pozwala na dokonanie rzetelnej diagnozy klienta. Z tej perspektywy pracownik socjalny występuje jako badacz, posiadający na co dzień dostępne instrumenty (psycholog, prawnik, specjalista pracy z rodziną), pozwalają-

${ }^{7}$ K. Schier, Dorosłe dzieci. Psychologiczna problematyka odwrócenia ról w rodzinie, Wydawnictwo Naukowe Scholar, Warszawa 2014. 
ce na nawiązanie autentycznej relacji z rodziną. Oprócz kontaktu indywidualnego ze środowiskiem, organizuje raz w miesiącu spotkania grupowe ze swoimi klientami, a za pomocą dostępnych w zespole specjalistów jest w stanie zdiagnozować sytuację dziecka w rodzinie, jego potrzeby, możliwości. Praca socjalna z rodziną jest zatem stała, intensywna i dotyczy ważnych dla niej problemów. Pracownik socjalny nie występuje już tylko w roli urzędnika przyznającego finansowe wsparcie, ale jest także lokalnym animatorem - koordynuje działania środowiskowe. W zespole złożonym z pracowników socjalnych, asystentów rodziny, specjalistów pracy socjalnej oraz psychologa ma możliwość interdyscyplinarnej pracy, również pod superwizją.

W ramach zadania Aktywna integracja świadczone są usługi asystenta rodziny, specjalistów pracy z rodziną, psychologa, prawnika, a także wyjazdowe treningi kompetencji rodzicielskich. Asystent rodziny pracuje maksymalnie z 10 środowiskami, w przypadku czasowego umieszczenia przez sąd dziecka poza rodziną współpracuje również z rodziną spokrewnioną, koordynatorem pieczy zastępczej. Jego zadaniem jest wypracowanie u wszystkich członków rodziny zmiany wobec własnej sprawności, podniesienia poczucia wartości. W przypadku pracy nad rodziną biologiczną, starającą się o powrót dziecka, asystent musi zharmonizować działania z zespołem interdyscyplinarnym wobec analizy przyczyn niewydolności. Otrzymuje również wsparcie specjalisty pracy z rodziną, który pracuje z nim równolegle w środowisku rodzinnym, w zakresie wzmacniania go w rozwiązywaniu problemów psychologicznych i wychowawczych. Jego praca nie podlega superwizji, jest samodzielnym kreatorem działań wobec pracy w systemie zadaniowym.

Poradnictwo specjalistyczne świadczone przez specjalistów pracy z rodziną jest skoncentrowane na 3 rodzajach działań: konsultacjach indywidualnych $\mathrm{z}$ rodziną, warsztatach edukacyjnych - Klub Aktywnego Rodzica oraz świetlicy rodzicielskiej „Spotkanie z przygodą”.

Klub Aktywnego Rodzica to cykl 7 spotkań, koncentrujących się na obszarze faz rozwojowych dziecka, odczytywania jego emocji, wprowadzania asertywnych granic w życie rodziny, roli przekazu międzypokoleniowego na wychowanie. Warsztaty, których celem jest ćwiczenie umiejętności obserwacji dziecka i interpretacji jego zachowania zawierają element arteterapii. Zajęcia „Spotkanie z przygodą” prowadzone są podczas świetlicy rodzicielskiej - miejsca spotkań rodziców, rodziców z dziećmi. To przestrzeń do budowania relacji, wymiany doświadczeń, nawiązania współpracy rodzicielskiej. Działania opierają się na założeniu, że zabawa to metoda terapeutyczna pozwalająca na nieinwazyjne wprowadzenie ćwiczeń z zakresu komunikacji, budowania relacji w rodzinie, przeżywania pozytywnych emocji, organizowania konstruktywnych form alokacji czasu wolnego.

Rodzina dysfunkcyjna skierowana przez pracownika socjalnego do specjalistów pracy z rodziną zostaje zdiagnozowana pod kątem przeżywanych trudności, potencjału i zdolności do zmian. Następnie, w zależności od charakteru dysfunkcji, praca $\mathrm{z}$ rodziną rozpoczyna się od zajęć z dziećmi w świetlicy rodzicielskiej, konsultacji 
indywidualnych oraz warsztatów edukacyjnych w Klubie Aktywnego Rodzica. Każda $z$ powyższych form wsparcia proponowana jest na innym etapie pracy z rodziną, finalnie doprowadzając do korzystania z wszystkich działań w sposób komplementarny. W trakcie spotkań świetlicowych rodziców z dziećmi, następuje modelowanie zachowań w postaci ćwiczeń praktycznych, wprowadzanie zasad i podział ról. Spotkania indywidualne z poszczególnymi rodzicami koncentrują się wokół poznania przyczyn i analizowania skutków przeżywanego kryzysu, ukazania cyrkularności i wpływu przekazów międzypokoleniowych. W przypadku podejrzeń związanych z wystąpieniem zaburzeń zachowania, psychicznych następuje przekierowanie do kontaktu indywidualnego z psychologiem.

Udział w warsztatach edukacyjnych na doskonalić umiejętność nazywania, scharakteryzowania występujących trudności i stosowanie adekwatnych rozwiązań. Początkowo, w ramach zadania Aktywna integracja w odniesieniu do działań specjalistów pracy z rodziną, funkcjonowały instrumenty związane $\mathrm{z}$ warsztatami psychoedukacyjnymi oraz terapią rodzinną. Ze względu jednak na nieumiejętność utrzymywania systematycznych kontaktów u klientów pomocy społecznych, niską zdolność do utrzymywania motywacji, obniżoną normę intelektualną, niechęć do działań terapeutycznych, lęk przed oceną ich kompetencji rodzicielskich, zdecydowano się na modyfikację działań, wprowadzając w nie formy terapii zajęciowej.

Po ukończeniu Klubu Aktywnego Rodzica, rodzice wraz z dziećmi biorą udział w pięciodniowym treningu wyjazdowym, gdzie mając do dyspozycji trenerów (każda rodzina znajduje się pod opieką jednego trenera), doskonalą korzystanie z własnych zasobów. Nadal stale mogą korzystać z zajęć świetlicowych i indywidualnych konsultacji.

Działania projektu „By-PAS Bytomska Pracownia Aktywności Społecznej”, w myśl koncepcji zintegrowanego modelu usług „cztery kręgi wsparcia”, oddziałują na najbliższe otoczenie sąsiedzkie, organizują społeczność lokalną w taki sposób, aby stanowiła program prewencyjny dla rodzin problemowych. Działania środowiskowe to spotkania ze społecznością funkcjonującą wśród rodzin niewydolnych wychowawczo, dysfunkcyjnych, koncentrujące się wokół przeprowadzania kampanii edukacyjnych. Podczas spotkań w poszczególnych dzielnicach Bytomia poruszane są takie zagadnienia, jak: sposoby reagowania na przemoc domową, rażące przykłady zaniedbań wobec dziecka, zagrożenia związane z odbieraniem dzieci do pieczy zastępczej, zapewnienie dzieciom bezpiecznych warunków w rodzinie biologicznej lub zastępczej, wczesne wspomaganie rozwoju dziecka.

\section{Zakończenie}

Proces zmian zachodzących w osobowości, systemie wartości, przekonań jest procesem długotrwałym i często niewspółmiernym do zakładanych w projektach celach. Nierzadko wzrost umiejętności, kompetencji opiekuńczo-wychowawczych bę- 
dzie skorelowany z rozpoczęciem identyfikacji potrzeb i oczekiwań dziecka przez rodzica. Zauważeniem tego, co lubi, co sprawia mu radość, z nazwaniem jego mocnych stron. Jednak możliwość ubiegania się o dofinansowanie programów pozwala na wypróbowanie nowych narzędzi pracy, zbadanie efektywności istniejących rozwiązań systemowych, a także holistyczne zatroszczenie się o jednostkę ludzką. Co więcej, uzyskiwane $\mathrm{w}$ ramach projektów rezultaty, mogą być po zakończonych działaniach wyjściem do zaadaptowania w instytucji wypracowanych standardów.

Praca $z$ rodziną powinna przebiegać na trzech poziomach wsparcia: profilaktyki, interwencji oraz integracji, $\mathrm{z}$ naciskiem na prewencyjne wzmacnianie rodzin w ich funkcji wychowawczej, zapobiegając tym samym występowaniu sytuacji kryzysowych prowadzących do zaniedbania dziecka i finalnego umieszczenia go w pieczy. W tych działaniach oprócz pracy z poszczególnymi członkami rodziny istotne jest równoległe stymulowanie otoczenia sąsiedzkiego do ponownej socjalizacji, wychowania do wartości wobec dziedziczonej kultury ubóstwa. Częstotliwość pracy z rodziną i jej efektywność zależy również od wypracowania przez wszystkich specjalistów zaangażowanych w rodzinę, spójnego modelu pracy i stosowania konsekwentnych metod (mówienie „jednogłosem”). Istotne jest także to, aby sami specjaliści zajmujący się rodziną mieli możliwość uzyskania wsparcia w postaci superwizji ich pracy. Superwizji prowadzonej w nurcie empowermentu, która koncentruje się nie na kontroli i ocenie pracowników, lecz pochyla się nad ich refleksjami. A jednocześnie doskonali umiejętność poznawania życia i doświadczeń klientów, pokazuje ich możliwości radzenia sobie w codzienności, z wykształconymi mechanizmami obronnymi.

\section{Bibliografia}

Chrząstowski Sz., Nie tylko schemat. Praktyka systemowej terapii rodzin, Wydawnictwo „Paradygmat”, Warszawa 2014.

Hrynkiewicz J., Zakres, kierunki zmian w pomocy społecznej, [w:] M. Rymsza (red.), Reformy społeczne - bilans dekady, Wydział Nauk Społeczno-Pedagogicznych Wyższej Szkoły Pedagogicznej, Warszawa 2001.

Schier K., Dorosłe dzieci. Psychologiczna problematyka odwrócenia ról w rodzinie, Wydawnictwo Naukowe Scholar, Warszawa 2014.

Szatkowski B., Instrumenty wsparcia rodziny - ujęcie porównawcze rozwiązań przyjętych $w$ Polsce i USA, „Państwo i Społeczeństwo”, nr 3/2013.

Szlendak T., Socjologia rodziny. Ewolucja, historia, zróżnicowanie, Wydawnictwo Naukowe PWN, Warszawa 2011.

www.bytom.pl/obszar-strategicznej-interwencji (dostęp: 6.06.2017).

www.efs.2007-2013.gov.pl/dokumenty/zmianywdokumentach/documents/zasady $7 \quad 1$ 2015.pdf (dostęp: 6.06.2017). 
Forms of family support as part of EU projects. Systemic work with families according to the opinion of specialists

Abstract: This article presents - as an example of good practice - forms of work with families as part of the „By-PAS Bytomska Pracownia Aktywności Społecznej” project. The article analyses activities aimed at families at risk and the competence of social workers. Analysis was conducted according to the US integrated model of "Four Support Circles". In work with dysfunctional families, attention was paid to the need for interaction at three levels of support: prevention, intervention and integration, simultaneously with the organising of the local community.

Keywords: EU project, dysfunctional family, community organisation, poverty culture, social assistance

About the author: Kinga Konieczny - pedagogue, specialist in working with family in
the Municipal Family Assistance Center in Bytom, Poland. PhD student at the Depart-
ment of General Pedagogy and Methodology of Research at the Department of Ethnology
and Educational Sciences, University of Silesia in Cieszyn, Poland. The area of scientific
interest concerns pedagogy of care and education (the importance of non-governmental
organizations in supporting problem families), rehabilitation pedagogy and education of
children from dysfunctional families. 


\title{
Uwarunkowania procesu zmagania się z uzależnieniem od alkoholu. Studium przypadku
}

\begin{abstract}
Streszczenie: $\mathrm{W}$ artykule przedstawiono analizę uwarunkowań towarzyszących pokonywaniu choroby alkoholowej $\mathrm{z}$ wyłączeniem korzystania $\mathrm{z}$ terapii instytucjonalnych. Punktem wyjścia dla rozważań uczyniono koncepcję polityki redukcji szkód, a także wskazanie czynników wspomagających i utrudniających proces leczenia uzależnienia. W tekście podjęto próbę wykazania, że istnieje możliwość wyzdrowienia dzięki posiadanym predyspozycjom osobowościowym, zasobom środowiskowym, a także sytuacyjnym, które wspomagają proces motywacyjny i decyzyjny osoby uzależnionej. Analiza wyników badań pozwoliła wyłonić kluczowy element procesu wychodzenia z nałogu, jakim jest podjęcie decyzji zmiany swojego życia pod wpływem krytycznego wydarzenia. Za szczególnie pomocną kategorię analizy uznano koncepcję „punktu zwrotnego”, czyli zdarzenia, które motywuje osobę do podjęcia aktywności na rzecz znaczących zmian w życiu, po których jednostka nie jest już taką samą, jaką była wcześniej.
\end{abstract}

Słowa kluczowe: uzależnienie od alkoholu, samowyleczenie, punkt zwrotny, czynniki wspierające proces leczenia uzależnienia

* Katarzyna Okólska - magister pedagogiki, w specjalności pedagogika resocjalizacyjna, doktorantka na Wydziale Nauk o Wychowaniu Uniwersytetu Łódzkiego, pedagog w Specjalistycznym Psychiatrycznym Zespole Opieki Zdrowotnej, w oddziale psychiatrycznym dla dzieci, szpitala im. J. Babińskiego w Łodzi. Zainteresowania naukowe: oddziaływania kuratorów sądowych w ramach pracy w środowisku otwartym, kara ograniczenia wolności, współczesne tendencje leczenia uzależnienia od alkoholu. 


\section{Wprowadzenie}

Współcześnie przyjmuje się, że leczenie uzależnienia od alkoholu może przyjmować różne formy ${ }^{1}$. Głównie jest to leczenie o charakterze terapeutycznym, ale również stosuje się rozwiązania farmakologiczne. Obecnie w metodach terapeutycznych i profilaktycznych wykorzystuje się zasoby i możliwości między innymi interwencji kryzysowej, która angażuje najbliższe otoczenie jednostki uzależnionej w proces uświadamiania problemu². Inną metodą jest terapia poznawcza, której założeniem jest identyfikacja zniekształceń poznawczych, a następnie ich redukcja na rzecz bardziej obiektywnego postrzegania rzeczywistości ${ }^{3}$. Należy wspomnieć o terapii poznawczo-behawioralnej, która łączy założenia warunkowania klasycznego i instrumentalnego z oddziaływaniem na struktury poznawcze człowieka ${ }^{4}$. Warto również wymienić wywiad motywujący, który skupia się przede wszystkim na pracy nad motywacją wewnętrzną jednostki ${ }^{5}$. Jednak najczęściej stosowaną terapią w Polsce jest integracyjna psychoterapia uzależnień, która wykorzystuje założenia terapii strategiczno-strukturalnej, behawioralno-poznawczej, teorii społecznego uczenia się, a także podejścia psychodynamicznego czy humanistyczno-egzystencjalnego ${ }^{6}$. Chociaż terapia ta przewiduje tworzenie osobistego planu leczenia pacjenta, który różnicuje tempo czy poziom przejścia przez kolejne etapy, to jednak narzuca pewien schemat tworzenia takiego planu z uzależnionym. Dlatego analiza istniejących form terapii pozwala sądzić, iż najbardziej zindywidualizowaną metodą leczenia uzależnień jest terapia redukcji szkód, której głównym celem jest skupienie się na zredukowaniu zniszczeń, jakie spowodował alkoholizm w różnych obszarach życia jednostki . Jedocześnie dając uzależnionemu możliwość podjęcia decyzji nad określeniem celu terapii na mia-

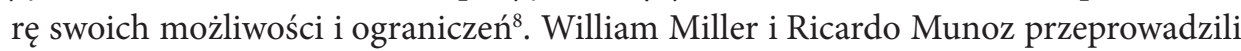
badania, na podstawie których opracowali profil osób, które mogą dążyć do ograni-

${ }^{1}$ M. Wnuk, J. Marcinkowski, Alkoholizm - przegląd koncepcji oraz metod leczenia, „Hygeia Public Heath", nr 1/47/2012, s. 49-55.

${ }^{2}$ B. Woronowicz, Uzależnienia. Geneza, terapia, powrót do zdrowia, Wydawnictwo Media Rodzina \& Wydawnictwo Edukacyjne PARPAMEDIA, Warszawa 2009.

${ }^{3}$ D. Barry, N. Petry, Poznawczo-behawioralne terapie uzależnień, [w:] P. Miller (red.), Terapia uzależnień. Metody oparte na dowodach naukowych, Wydawnictwo Uniwersytetu Warszawskiego, Warszawa 2014, s. 167-180.

${ }^{4}$ Tamże.

${ }^{5}$ W. Miller, S. Rollnick, Wywiad motywujący. Jak przygotować ludzi do zmiany, Wydawnictwo Uniwersytetu Jagiellońskiego, Kraków 2010.

${ }^{6} \mathrm{~J}$. Mellibruda, Z. Sobolewska-Mellibruda, Integracyjna psychoterapia uzależnień. Teoria i praktyka, Instytut Psychologii Zdrowia, Warszawa 2006.

7 A. Tatarsky, Psychoterapia mająca na celu redukcję szkód, [w:] A. Tatarsky (red.), Redukcja szkód w psychoterapii, Krajowe Biuro do spraw Przeciwdziałania Narkomanii, Warszawa 2007.

${ }^{8}$ A. Jakubczyk, M. Wojnar, Całkowita abstynencja czy redukcja szkód - różne strategie terapii uzależnienia od alkoholu wświetle badań i międzynarodowych zaleceń, „Psychiatria Polska”, nr 3/2012, s. 373-386. 
czenia spożywania alkoholu9 . Jednak należy pamięć, że aktualnie nie posiadamy narzędzi do predykcji i należy podchodzić ostrożnie do wniosków tych badaczy. Przede wszystkim w tworzeniu planu terapii z pacjentem trzeba mieć na uwadze heterogeniczność grupy osób uzależnionych od alkoholu ${ }^{10}$.

W leczeniu farmakologicznym stosuje się takie środki, jak apomorfina, insulina (w celach niedocukrzenia organizmu), a przy detoksykacji disulfiram, znany współcześnie jako Esperal, który wszywa się podskórnie w postaci implantu ${ }^{11}$. Współcześnie stosuje się również leki oddziałujące na układy neuroprzekaźników, które mają pomóc wydłużyć okres abstynencji ${ }^{12}$.

Można także mówić o tak zwanych „samoistnych remisjach”"13, definiowanych przez Światową Organizację Zdrowia jako: „zaprzestanie nadużywania alkoholu lub innych środków psychoaktywnych, przezwyciężenie uzależnienia lub innych problemów, bez korzystania z terapii"14. Innymi słowy, samoistna remisja czy samowyleczenie stanowi proces, w którym przy rezygnacji z pomocy specjalistycznej wykorzystuje się sieć wsparcia społecznego jednostki oraz jej inne zasoby osobiste ${ }^{15}$.

W piśmiennictwie naukowym wśród czynników wspomagających proces leczenia zaznacza się rolę zasobów osobistych jednostki, określanych przez Rudolfa Moosa jako „względnie stałe czynniki osobowe i społeczne, które wpływają na sposób, w jaki jednostka próbuje opanować kryzysy życiowe" ${ }^{16}$. Zalicza się do nich sieć wsparcia społecznego, strategie radzenia sobie ze stresem, świadomość własnych możliwości i ograniczeń, poziom samokontroli, koherencji oraz asertywności ${ }^{17}$. Należy tutaj podkreślić znaczenie roli wsparcia społecznego w procesie leczenia ${ }^{18}$, które jest eksponowane przez badaczy jako czynnik będący w korelacji z podjęciem decyzji o le-

9 W. Miller, Muñoz R., Picie kontrolowane. Sposoby na umiarkowanie, Wydawnictwo Edukacyjne PARPA, Warszawa 2006.

${ }^{10}$ L. Sobell, M. Sobell , T. Toneatto, G. Leo, What triggers the resolution of alcohol problems without treatment, „Alcoholism, Clinical and Experimental Research”, nr 17/1993, s. 217-224.

${ }^{11}$ B. Woronowicz, dz. cyt.

12 P. Miller, dz. cyt.

${ }^{13}$ G. Walters, Spontaneous remission from alcohol, tobacco, and other drug abuse: seeking quantitative answers to qualitative questions, "American Journal of Drug and Alcohol Abuse”, nr 3/26/2000, s. 443-460.

${ }^{14}$ Światowa Organizacja Zdrowia, Leksykon terminów. Alkohol i Narkotyki, Instytut Psychiatrii i Neurologii, Warszawa 1997.

${ }^{15}$ K. Harald, H. Klingemann, L. Sobell, Introduction: natural recovery research across substance use, „Substance Use \& Misuse”, nr 11/36/2001, s. 1409-1416.

${ }_{16}$ R. Moos, J. Schaefer, Coping Resources and Process: Current Concepts and Measures, [w:] L. Goldberger, S. Breznits (red.), Handbook of Stress: Theoretical and clinical aspects, The Free Press, New York 1993, s. 234, za: J. Chodkiewicz, Rola zasobów osobistych w utrzymaniu abstynencji przez mężczyzn uzależnionych od alkoholu, „Alkoholizm i Narkomania”, nr 2/2001, s. 277-287.

17 J. Chodkiewicz, dz. cyt.

18 A. Krupa, K. Bargiel-Matusiewicz, G. Hofman, Zwiqzek wsparcia społecznego ze stosowaniem strategii radzenia sobie ze stresem w grupie osób uzależnionych od środków psychoaktywnych, „Alkoholizm i Narkomania", nr 1-2/18/2005, s. 57-69. 
czeniu uzależnienia oraz utrzymaniu się w postanowieniach $\mathrm{z}$ niej wynikających ${ }^{19}$. Natomiast badacze wskazują, że czynnikami utrudniającymi wychodzenie z nałogu alkoholowego jest brak wsparcia rodziny i przyjaciół, stabilnej sytuacji życiowej (zawodowej, mieszkaniowej), rosnąca dostępność substancji uzależniających, a także stygmatyzacja społeczna osób uzależnionych ${ }^{20}$. Saul Shiffman w swoich badaniach wymienia również cechy osobowości jednostki, temperament, nagromadzenie sytuacji stresowych, czy czynniki wyzwalające, takie jak wahania nastroju ${ }^{21}$.

Celem niniejszego opracowania jest wskazanie uwarunkowań, które okazały się być wspierające bądź utrudniające proces samodzielnego przezwyciężania uzależnienia od alkoholu. Badaną osobą był mężczyzna, który podjął walkę ze swoją chorobą bez udziału tzw. specjalistycznych form wsparcia. „Terapia” (a właściwie „autoterapia”), którą zastosowała osoba badana nie wpisuje się w kanony współczesnych metod leczenia instytucjonalnego, a przedstawia proces samodzielnego zmagania się osoby uzależnionej ze swoim problemem ${ }^{22}$. W związku z tym zamierzam również wskazać na istotę przyjętej przeze mnie kategorii punktu zwrotnego, stanowiącego pewnego rodzaju kryzys w życiu jednostki²3, który oddziałuje na motywację i proces decyzyjny w ciągłości biograficznej człowieka uzależnionego od alkoholu. Wreszcie, w odniesieniu do powszechnych metod leczenia uzależnień (szczególnie w Polsce), zamierzam podkreślić znaczenie indywidualnego nastawienia do uzależnionej jednostki w metodach terapii.

\section{Badania własne}

W badaniach własnych wykorzystałam metodę biograficzną, w której zasadniczą techniką zbierania danych jest wywiad autobiograficzny ${ }^{24}$. Powołując się na rozważania Danuty Lalak posłużyłam się biografią podmiotową (autobiografia), ponieważ osoba badana udzielając wywiadu o charakterze narracyjnym, opowiadała własną historię życia ${ }^{25}$. Uzyskałam długi, wielowątkowy, autobiograficzny wywiad narracyjny. Narrator był czterdziestoletnim mężczyzną, który od lat borykał się z uzależnieniem

19 A. Jakubik, B. Kowalik, Wsparcie społeczne a utrzymywanie abstynencji u mężczyzn uzależnionych od alkoholu, „Alkoholizm i Narkomania”, nr 1/26/1997, s. 89-103.

${ }^{20}$ J. Żulewska-Sak, K. Dąbrowska, Percepcja społeczna czynników udaremniajacych samodzielne przezwyciężenie uzależnienia - jakościowa analiza porównawcza, „Alkoholizm i Narkomania, nr 3/18/2005, s. 63-77.

${ }^{21}$ S. Shiffman, Problemy pojęciowe w badaniach nad nawrotami, [w:] M. Gossop (red.), Nawroty $w$ uzależnieniach, PARPA, Warszawa 1997.

${ }^{22}$ J. Żulewska, Potencjał samouzdrawiajacy osób doświadczajacych problemów zalkoholem. Przegląd badań nad zjawiskiem samowyleczeń, „Alkoholizm i Narkomania”, nr 4/18/2010, s. 9-24.

${ }_{23}$ A. Strauss, Mirrors and Masks. The Search for Identity, Robertson \& Co, London 1977.

${ }^{24}$ G. Rosenthal, Badania biograficzne, [w:] K. Kaźmierska (red.), Metoda biograficzna w socjologii. Antologia tekstów, Zakład Wydawniczy NOMOS, Kraków 2012.

${ }^{25}$ D. Lalak, Życie jako biografia, Wydawnictwo Akademickie „Żak”, Warszawa 2006. 
od alkoholu, podejmując bezskuteczne próby pokonania problemu. Jednak ze względu na unikalność mojego przypadku zdecydowałam się na pominięcie etapów analizy tekstów biograficznych, takich jak porównywanie kontrastowe, czy sprawdzanie hipotez przez zestawienie materiałów empirycznych, pochodzących z wywiadów z różnymi osobami ${ }^{26}$. Dlatego należy zaznaczyć, że jest to studium pojedynczej biografii, a swoje badania zamierzam kontynuować dla zachowania całości procedur analizy tekstów biograficznych.

\section{Kariera alkoholika - proces rozwoju choroby, rzutujący na różne płaszczyzny życia}

W socjologii interpretatywnej pojęcie „kariery” jest rozumiane w szerszym kontekście niż powszechne kojarzenie z drogą zawodową człowieka. Przedstawiciele tzw. szkoły chicagowskiej wykorzystywali pojęcie „kariery” jako kategorię analityczną ${ }^{27}$. Jest to termin stosowany w celu ukazania pewnych zmian w biografii jednostki, które są dostrzegalne zewnętrznie - np. zmiana statusu, oraz te dziejące się na płaszczyźnie emocjonalnej jednostki - np. postrzeganie samego siebie ${ }^{28}$. W literaturze można spotkać się z karierą poety ${ }^{29}$, dewianta ${ }^{30}$, pacjenta szpitala psychiatrycznego ${ }^{31}$ czy przestępcy ${ }^{32}$. Wykorzystanie tego terminu w kontekście choroby alkoholowej mojego rozmówcy pomogło zobrazować etapowość, jaką można dostrzec w pogłębianiu się jego uzależnienia. Co więcej, należy zwrócić uwagę na wyłaniające się zjawisko „pokonywania” kryzysów w biografii narratora czy właśnie wspomnianych etapów. Osoba badana ostatecznie stawała naprzeciw swym trudnościom życiowym, ukazując tym samym siebie jako podmiot działający, a nie bierny uczestnik zjawisk społecznych i innych okoliczności.

Pierwsze moje spotkanie z alkoholem było już w szkole średniej, ale to nic nadzwyczajnego, w tamtych czasach pił każdy, palił każdy. Takie były czasy. [...] Zdarzali się ludzie, którzy nie pili w ogóle, ale byli wykluczeni, jak by to powiedzieć, z takiego społeczeństwa, z takiego topu. Ja zawsze lubiłem tam być, w tym miejscu, choć nie miałem do tego warunków. Nie miałem tej pewności

${ }^{26}$ G. Rosenthal, dz. cyt.

${ }^{27}$ K. Konecki, Praca w koncepcji socjologii interakcjonistycznej, „Studia Socjologiczne”, nr 1/1988, s. 225-245.

${ }^{28}$ G. Riemann, F. Schütze, Trajektoria jako podstawowa koncepcja teoretyczna $w$ analizach cierpienia i bezładnych procesów społecznych, „Kultura i Społeczeństwo”, nr 2/1992, s. 249-274.

${ }_{29}$ I. Ślęzak, Stawanie się poetą. Analiza interakcjonistyczno-symboliczna, „Przegląd Socjologii Jakościowej", nr 1/2009, s. 1-175.

${ }^{30}$ H. Becker, Outsiderzy: studia z socjologii dewiacji, Wydawnictwo Naukowe PWN, Warszawa 2009.

${ }^{31}$ E. Goffman, Instytucje totalne, Gdańskie Wydawnictwo Psychologiczne, Gdańsk 2011.

32 R. Szczepanik, Stawanie się recydywistą. Kariery instytucjonalne osób powracających do przestępczości, Wydawnictwo Uniwersytetu Łódzkiego, Łódź 2015. 
siebie, ale zawsze miałem kolegów, zawsze wypiłem. Wszędzie mnie było pełno. Między innymi też przez alkohol to pomagało mi jakoś być w tym takim topie.

Badany ujawniał niskie poczucie własnej wartości, a alkohol odgrywał znaczącą rolę w budowaniu jego wizerunku od wczesnej młodości. Używka ta wzmacniała jego pewność siebie oraz pozycje w grupie rówieśniczej. Rozmówca chciał czuć się postrzegany przez otoczenie lepiej niż on sam siebie widział. Co więcej, narrator uznał, że głównymi determinantami funkcjonowania w znaczącej części grupy społecznej było spożywanie alkoholu z innymi, co mogło stanowić uproszczenie drogi osiągnięcia pożądanego statusu.

W pracy, jak to jeszcze za tamtych czasów, pierwszą zmianę zaczynało się od kielicha. Ja miałem to nieszczęście, szczęście, czy ja wiem, trudno to określić, miałem dobrego nauczyciela, który za kołnierz nie wylewał, ale nauczył mnie też dobrej roboty i za to jestem mu wdzięczny. Aczkolwiek napić się musiałem, bo pili wszyscy. [...] ale praca musiała być zrobiona, uważałem, że przez pracę też dbam o rodzinę [...] to był dla mnie chyba większy priorytet niż wódka.

Narrator po ukończeniu kariery edukacyjnej doświadczył kontaktu z niesprzyjającym środowiskiem zawodowym, w którym alkohol był obecny. Chociaż trzeba przyznać, że badany charakteryzował się niskim poziomem asertywności, co wprost pokazuje mówiąc, że „musiał” się napić alkoholu w pracy, ponieważ wszyscy pili. Zapewne miało to związek $\mathrm{z}$ chęcią wykreowania siebie w oczach innych jako osobę pewną siebie i równą $z$ innymi, obawiając się jednocześnie wykluczenia. Dlatego można uznać, że znaczącymi determinantami wczesnych problemów z alkoholem osoby badanej były niskie poczucie własnej wartości oraz uległość.

Przyszedł jeszcze jeden czynnik, który jakoś dopomagał w piciu. Zaczęły się problemy w pracy, bo tak nie miałem żadnych. [...] Fajnie było, znana rzecz jak się wypiło, mniej się pamiętało o problemach. Tak to się zaczęło. Moi starzy znajomi odeszli delikatnie na bok z tego powodu, że tak jak mówiłem, czułem się pewien. Przychodzili nowi i to niekoniecznie sprawdzeni.

Komplikacje w pracy rozmówca określił jako kolejną przyczynę nadmiernego sięgania po alkohol. Wskazuje to na pewną „falowość” następujących po sobie trudnych wydarzeń, które powodowały pogłębianie się problemu uzależnienia. W związku z tym można zauważyć, że alkohol stał się „odskocznią” od rosnących trudności, czyli stan upojenia alkoholowego zyskał nowe znaczenie - stał się sposobem ucieczki od próby rozwiązania problemów życiowych.

Zaczęły się niesnaski w domu z żoną. Aczkolwiek, osoba ta nie pomagała w całej sytuacji, a wręcz wkurzała i przez nią też człowiek wolał wyjść z domu się napić, żeby nie słyszeć jazgotu, czy tam narzekania, no tak to chyba się zaczęło. Najgorzej to na tym wszystkim to wychodziła chyba córka, aczkolwiek nie dała po sobie pokazać, że się martwi czy że jest coś nie tak. Radziła sobie świetnie. To też może kuriozum, w jakiś sposób pomogło. Nie było problemu z nią i tu człowiek nie zwracał na to uwagi. Nie musiał poświęcić tutaj więcej czasu i tak 
to wyglądało. [...] Rodzice kontrolowali rzeczy, pewnie widzieli już, że coś się dzieje, ale ja nie dawałem do siebie dojść, zablokowałem dostęp, o tak.

W biografii narratora pojawiły się zależności między relacjami rodzinnymi a rosnącym problem uzależnienia. Ujawniły się trzy płaszczyzny: relacje z żoną, relacje $\mathrm{z}$ córką i relacje $\mathrm{z}$ rodzicami. Żona narratora reagowała w sposób ekspresyjny, co wywoływało konflikty domowe. Córka narratora, nie chcąc sprawiać dodatkowych problemów, stała się „niewidzialna”, co paradoksalnie umożliwiło narratorowi większą swobodę działania. Tutaj można dostrzec dwie skrajności: z jednej strony czynna reakcja na zachowania osoby badanej doprowadzała do chęci sięgania po alkohol; $\mathrm{z}$ drugiej strony bierność również była sprzyjająca. Wreszcie nastawienie rodziców rozmówcy do pogarszającej się sytuacji było wątpliwe, ponieważ narrator postawił barierę dookoła siebie, tak by nie mogli podjąć jakichkolwiek interwencji. Nasuwa się schemat tzw. błędnego koła - najbliższe otoczenie narratora dostrzegało problem rozwijającego się uzależnienia, w związku z tym narrator ograniczał te kontakty, by objawy uzależnienia były mniej widoczne. To zjawisko powodowało coraz mniejsze możliwości w podjęciu interwencji ze strony środowiska rodzinnego czy rówieśniczego, które zostało odsunięte.

Zaczęła się przygoda z nową pracą i tak naprawdę największe pijaństwo. [...] Jako że mnie w pracy nikt nie kontrolował, a po mnie ciężko było poznać, że ja cokolwiek wypiłem, to alkoholu robiło się coraz więcej. [...] Nie wiem, jak ja to wytrzymywałem i prowadziłem firmę. [...] Były pieniądze, ale było moje picie. W pracy najbliżsi nie dopuszczali do tego, by inni widzieli mnie pijanego, starali się pewnie dużo rzeczy robić za mnie, aczkolwiek ja mimo wszystko trzymałem pracę w garści, a w pewnym momencie już nawet na każde banalne wyjście $\mathrm{z}$ domu to była setka, uzależniłem się od setek. Wtedy piłem naprawdę dużo.

Ostatni etap uzależnienia przed decyzją o podjęciu próby walki z problemem cechuje się całkowitą utratą kontroli badanego. Objawiało się to ponowną zmianą charakteru picia, ponieważ alkohol stał się tym razem stałym elementem codziennego życia narratora. Sam również przyznał, że nie był pewien, jak w tamtym okresie wszystko wyglądało, w jaki sposób udało mu się pogodzić pracę z trudnościami, jakie niosło ze sobą uzależnienie.

\section{Punkt zwrotny - początek drogi wychodzenia z nałogu alkoholowego}

Wydarzenie niosące znamiona punktu zwrotnego było wyraźnie dostrzegalne w biografii osoby badanej. Przede wszystkim dlatego, że narrator doświadczył wcześniej trudnych sytuacji w życiu, ale dopiero to jedno wydarzenie doprowadziło do podjęcia decyzji o podjęciu aktywności zmierzającej ku wyjściu z nałogu alkoholowego. 
Pamiętam jedną awanturę, taką po wódce, dosyć poważną. [...] Nie wiem, czy to nie zadziałało, ale Kuba miał tak z 3-4 lata i pierwszy raz to zobaczył i pamiętam do tej pory jego strasznie zszokowaną twarz. Wstydzę się tego strasznie, ale już nic na to nie poradzę. Wtedy nastąpił, nie wiem tak naprawdę jak to się stało, w moim życiu często zdarzały się sytuacje, że z jakiegoś powodu robiłem coś i zmieniało to bieg mojego życia w drugą stronę zupełnie.

Dominującym uczuciem, jakie towarzyszyło narratorowi i które było głównym powodem podjęcia decyzji o walce z nałogiem był wstyd. Poczucie wstydu wywołało przełom, którego następstwem stało się wdrożenie „nowego planu na życie”. Biorąc pod uwagę powyższy fragment wywiadu należy sądzić, że przytoczona sytuacja mocno zakorzeniła się w pamięci badanego. Chociaż powszechnie wiadomo, że narodziny dziecka stanowią znaczący bodziec wywołujący modyfikacje w życiu rodziców, w przypadku mojego rozmówcy nastąpiło to nieco później. Niemniej opisana sytuacja pobudziła wewnętrzne zasoby motywacyjne, które wzmocniły narratora w podjęciu decyzji o wprowadzeniu zmian i rozpoczęciu drogi wyjścia z uzależnienia od alkoholu.

\section{Czynniki wspomagające wdrożenie strategii wychodzenia z nałogu}

Po prostu postanowiłem się zaszyć i nie pić kompletnie nic. Z własnej woli. Jeszcze raz powtarzam, z własnej woli [...] pojechałem do szpitala i się zaszyłem. [...] Rodzina, wszyscy byli zadowoleni, wszyscy patrzyli na mnie z niedowierzaniem, ale $\mathrm{z}$ taką cały czas niepewnością i niewiarą. [...] Z wielką pomocą, z wielką pomocą, mówię to w pełni świadom, wyszli do mnie moi znajomi, przyjaciele, których odrzuciłem w pewnym momencie, poznając nowych, ci najstarsi. Zaczęliśmy się spotykać, ja nie piłem, zaczęła się konsolidować taka nowa, naprawdę nowa, wielka więź między nami, coś wspaniałego [...] bardzo duże wsparcie ze strony żeńskiej części naszej paczki, od dziewczyn. Za to im jestem dozgonnie wdzięczny. To one mi strasznie pomogły. [...] Teraz wiem, dlaczego miałem kiedyś przyjaciół, jak nie piłem, też miałem dużo znajomych, bo ja jestem z natury wesoły, wcale wódka czy inny alkohol do mojego wesołego usposobienia nie była mi potrzebna.

Badacze twierdzą, że w procesie samowyleczenia osoby uzależnione realizują własne strategie wyjścia $\mathrm{z}$ nałogu ${ }^{33}$. Tak samo było w przypadku mojego rozmówcy. Decyzja o zmianie dotychczasowego życia i trwanie w postanowieniach korelowały z czynnikami wspierającymi. Pierwszy element, który się pojawił to brak odgórnego przymusu wprowadzenia zmian w życiu osoby badanej. Podejmowane przez narratora decyzje wynikają z wewnętrznych zasobów motywacyjnych, a odnosząc się do

${ }^{33}$ S. Burman, The challenge of sobriety: natural recovery without treatment and self-help groups, „Journal of Substance Abuse”, nr 9/1997, s. 41-61. 
literatury przedmiotu zapewniają one trwalsze zmiany niż te wynikające z motywacji zewnętrznej ${ }^{34}$. Kolejnym czynnikiem obecnym przy realizacji nowego planu na życie było wsparcie społeczne, na które składała się między innymi rodzina narratora. $Z$ jego wypowiedzi wynika, że była dla niego ważna i wspierająca. Na sieć wsparcia społecznego osoby badanej składają się również jego przyjaciele, którzy wcześniej zostali odsunięci. Tutaj wyraźnie widać, jak istotna jest dla osoby wychodzącej z nałogu pomoc ze strony przyjaciół, którzy są obecni w życiu jednostki nieco inaczej niż rodzina, która w tym przypadku z początku patrzyła z nieufnością na działania narratora w kierunku wyleczenia. Jednak należy pamiętać, że dalsze otocznie jednostki odczuwało pośrednio następstwa choroby alkoholowej badanego. Dlatego jego przyjaciołom łatwiej było spojrzeć na niego ze zrozumieniem i wiarą, ponieważ najtrudniejszy etap choroby miał miejsce bez ich udziału.

Później nastąpił moment, w którym zacząłem wdrażać, realizować swój plan i nastąpił moment, który, jak gdyby wspomógł dalsze dążenie do normalności, to był zawał. [...] Nastąpił moment, gdzie bałem się opuścić ten świat na każdym kroku. Nie było dnia, żebym nie myślał o tym, że jak się umiera, to nie ma nic. To jest nieprawdopodobne uczucie... Na nowo zaczęło się, jak gdyby niepicie, taka wszywka wewnętrzna.

Obok poczucia wstydu, które zmotywowało narratora do podjęcia decyzji o zerwaniu z nałogiem, pojawił się strach przed śmiercią. Można sądzić, że dodatkowe schorzenie rozmówcy, które mogło skończyć się śmiercią, wygenerowało dłuższy okres abstynencji, który wzmocnił jego determinację do realizacji planu i trwania w kontroli. Co więcej, warto dodać, że narrator sam określa tę sytuację jako „wszywkę wewnętrzną" - czynnik, który niezależnie od czasu przypomina o strachu, który wiązał się z chorobą. Jest to zdecydowanie uwarunkowanie sytuacyjne, które znacząco oddziaływało na proces wychodzenia $\mathrm{z}$ uzależnienia. Jest to wydarzenie, którego narrator nie był w stanie przewidzieć, ani wpisać świadomie w biografię - pojawia się analogia do rozumienia przez Piotra Chomczyńskiego kategorii punktu zwrotnego ${ }^{35}$.

\section{Wnioski}

Ze względu na specyfikę problematyki podjętych przeze mnie badań, analizie poddałam jedynie pojedynczą autobiografię. Jednak udało mi się uzyskać bogaty materiał empiryczny, który umożliwił przezwyciężenie ograniczeń metodologicznych, które pojawiły się podczas realizacji badań. Niewątpliwie brak analiz porównawczych obecnych w metodzie biograficznej obniżają wartość wyników badań. Dlatego rozpatruję je jako wstęp do dalszych i pogłębionych analiz nad procesem walki z uzależ-

${ }^{34}$ W. Miller, S. Rollnick, dz. cyt.

${ }_{35}$ P. Chomczyński, Mobbing w pracy z perspektywy interakcyjnej, Wydawnictwo Uniwersytetu Łódzkiego, Łódź 2008. 
nieniem od alkoholu bez udziału profesjonalnych instytucji, zajmujących się terapią uzależnień.

Biorąc pod uwagę powyższą analizę, można stwierdzić, że jednym z czynników, które pomagają rozpocząć drogę wychodzenia z nałogu alkoholowego i trwania w postanowieniach, to sieć wsparcia najbliższego otoczenia uzależnionego, która może pełnić rolę doradców, motywatorów czy oparcia w trudnych chwilach. Równie istotnym elementem procesu pokonywania nałogu alkoholowego jest kategoria punktu zwrotnego, czyli wydarzenie w życiu jednostki noszące miano kryzysu. Inny komponent samodzielnego radzenia sobie $\mathrm{z}$ uzależnieniem to silna motywacja wewnętrzna, która jednak jest wywołana bodźcami zewnętrznymi, na przykład w postaci negatywnych i trudnych wydarzeń w życiu człowieka. Natomiast czynniki utrudniające proces wyjścia z nałogu czy oddziałujące na rozwój choroby alkoholowej to brak stabilizacji w życiu człowieka na płaszczyźnie zawodowej, społecznej i ekonomicznej.

Reasumując, przy pojawieniu się czynników wspomagających proces wychodzenia $\mathrm{z}$ nałogu alkoholowego istnieje szansa na pokonanie uzależnienia. Jednak należy pamiętać, że przedstawione w niniejszym artykule doświadczenia biograficzne osoby badanej są pojedynczym przypadkiem i nie każdy człowiek uzależniony od alkoholu jest w stanie podjąć taką drogę walki z nałogiem. Trzeba też dodać, że każdy uzależniony człowiek wchodzi w proces leczenia na innym poziomie rozwoju choroby. Co więcej, uwarunkowania sprzyjające procesowi leczenia również mają charakter indywidualny. Dlatego sposoby leczenia powinny być dostosowane do ograniczeń i możliwości pacjenta. Wreszcie ważne jest, by zaznaczyć, że leczenie bądź samoleczenie choroby alkoholowej jest procesem, którego czas trwania ma także charakter indywidualny. Dlatego nie można określić, czy stan kontroli osoby uzależnionej będzie permanentny.

\section{Bibliografia}

Barry D., Petry N., Poznawczo-behawioralne terapie uzależnień, [w:] P. Miller (red.), Terapia uzależnień. Metody oparte na dowodach naukowych, Wydawnictwo Uniwersytetu Warszawskiego, Warszawa 2014.

Becker H., Outsiderzy: studia z socjologii dewiacji, Wydawnictwo Naukowe PWN, Warszawa 2009.

Burman S., The challenge of sobriety: natural recovery without treatment and self-help groups, „Journal of Substance Abuse”, nr 9/1997, s. 41-61.

Chodkiewicz J., Rola zasobów osobistych $w$ utrzymaniu abstynencji przez mężczyzn uzależnionych od alkoholu, „Alkoholizm i Narkomania”, nr 2/2001, s. 277-287.

Chomczyński P., Mobbing w pracy z perspektywy interakcyjnej, Wydawnictwo Uniwersytetu Łódzkiego, Łódź 2008. 
Goffman E., Instytucje totalne, Gdańskie Wydawnictwo Psychologiczne, Gdańsk 2011. Szczepański J., Odmiana czasu teraźniejszego, Wydawnictwo Książka i Wiedza, Warszawa 1973.

Harald K., Klingemann H., Sobell L., Introduction: natural recovery research across substance use, „Substance Use \& Misuse”, nr 11/36/2001, s. 1409-1416.

Jakubczyk A., Wojnar M., Całkowita abstynencja czy redukcja szkód - różne strategie terapii uzależnienia od alkoholu $w$ świetle badań i międzynarodowych zaleceń, „Psychiatria Polska”, nr 3/2012, s. 373-386.

Jakubik A., Kowalik B., Wsparcie społeczne a utrzymywanie abstynencji u mężczyzn uzależnionych od alkoholu, „Alkoholizm i Narkomania”, nr 1/26/1997, s. 89-103.

Konecki K., Praca w koncepcji socjologii interakcjonistycznej, „Studia Socjologiczne”, nr 1/1988, s. 225-245.

Krupa A., Bargiel-Matusiewicz K., Hofman G., Zwiazek wsparcia społecznego ze stosowaniem strategii radzenia sobie ze stresem $w$ grupie osób uzależnionych od środków psychoaktywnych, „Alkoholizm i Narkomania”, nr 1-2/18/2005, s. 57-69.

Lalak D., Życie jako biografia, Wydawnictwo Akademickie „Żak”, Warszawa 2006.

Mellibruda J., Sobolewska-Mellibruda Z., Integracyjna psychoterapia uzależnień. Teoria i praktyka, Instytut Psychologii Zdrowia, Warszawa 2006.

Miller P., Terapia uzależnień. Metody oparte na dowodach naukowych, Wydawnictwo Uniwersytetu Warszawskiego, Warszawa 2014.

Miller W., Muñoz R., Picie kontrolowane. Sposoby na umiarkowanie, Wydawnictwo Edukacyjne PARPA, Warszawa 2006.

Miller W., Rollnick S., Wywiad motywujący. Jak przygotować ludzi do zmiany, Wydawnictwo Uniwersytetu Jagiellońskiego, Kraków 2010.

Moos R., Schaefer J., Coping Resources and Process: Current Concepts and Measures, [w:] L. Goldberger, S. Breznits (red.), Handbook of Stress: Theoretical and clinical aspects, The Free Press, New York 1993.

Riemann G., Schütze F., Trajektoria jako podstawowa koncepcja teoretyczna w analizach cierpienia i bezładnych procesów społecznych, „Kultura i Społeczeństwo”, nr 2/1992, s. 249-274.

Rosenthal G., Badania biograficzne, [w:] K. Kaźmierska (red.), Metoda biograficzna w socjologii. Antologia tekstów, Zakład Wydawniczy NOMOS, Kraków 2012.

Shiffman S., Problemy pojecciowe w badaniach nad nawrotami, [w:] M. Gossop (red.), Nawroty w uzależnieniach, PARPA, Warszawa 1997.

Sobell L., Sobell M., Toneatto T., Leo G., What triggers the resolution of alcohol problems without treatment, "Alcoholism, Clinical and Experimental Research”, nr 17/1993, s. 217-224.

Strauss A., Mirrors and Masks. The Search for Identity, Robertson \& Co, London 1977. Szczepanik R., Stawanie się recydywistą. Kariery instytucjonalne osób powracających do przestępczości, Wydawnictwo Uniwersytetu Łódzkiego, Łódź 2015. 
Ślęzak I., Stawanie się poetą. Analiza interakcjonistyczno-symboliczna, „Przegląd Socjologii Jakościowej”, nr 1/2009, s. 1-175.

Światowa Organizacja Zdrowia, Leksykon terminów. Alkohol i Narkotyki, Instytut Psychiatrii i Neurologii, Warszawa 1997.

Tatarsky A., Psychoterapia mająca na celu redukcję szkód, [w:] A. Tatarsky (red.), Redukcja szkód w psychoterapii, Krajowe Biuro do spraw Przeciwdziałania Narkomanii, Warszawa 2007.

Walters G., Spontaneous remission from alcohol, tobacco, and other drug abuse: seeking quantitative answers to qualitative questions, „American Journal of Drug and Alcohol Abuse", nr 3/26/2000, s. 443-460.

Woronowicz B., Uzależnienia. Geneza, terapia, powrót do zdrowia, Wydawnictwo Media Rodzina \& Wydawnictwo Edukacyjne PARPAMEDIA, Warszawa 2009.

Wnuk M., Marcinkowski J., Alkoholizm - przeglad koncepcji oraz metod leczenia, „Hygeia Public Heath", nr 1/47/2012, s. 49-55.

Żulewska J., Potencjał samouzdrawiający osób doświadczających problemów $z$ alkoholem. Przegląd badań nad zjawiskiem samowyleczeń, „Alkoholizm i Narkomania", nr 4/18/2010, s. 9-24.

Żulewska-Sak J., Dąbrowska K., Percepcja społeczna czynników udaremniających samodzielne przezwyciężenie uzależnienia - jakościowa analiza porównawcza, „Alkoholizm i Narkomania”, nr 3/18/2005, s. 63-77.

\section{Conditions conducive to the self-treatment of a person addicted to alcohol. A case study}

Abstract: The article analyses the conditions that accompany recovery from alcohol problems without institutional treatment. The point of departure is the harm reduction strategy and the factors supporting and hindering the process of addiction treatment. The article also discusses natural recovery (self-change) due to factors like: character traits, environmental resources and experiences, which support the addict's self-motivation. Based on the analysis of the research results, the crucial factor for autoremission is an individual's will to resolve his/her alcohol problems as a consequence of a life crisis. The notion of a "turning point" is particularly helpful to understanding how an individual chooses to make significant changes to his/her life.

Keywords: alcohol addiction, factors supporting the treatment process, natural recovery, turning point

About the author: Katarzyna Okólska - MA in pedagogy, in specialisation social rehabilitation, $\mathrm{PhD}$ student at Faculty of Edaucational Sciences, University of Lodz, pedagogue in Department of Child Psychiatry Babinski Memorial Hospital in Lodz. Academic interests: work of probation officers in an open environment, penalty of restricted liability, contemporary tendencies in the treatment of alcohol dependence. 


\title{
Agnieszka Hamerlińska* (iD https://orcid.org/0000-0002-9305-5793
}

Uniwersytet Mikołaja Kopernika w Toruniu

\author{
Emilia Kotlęga** \\ Uniwersytet Karola Wielkiego w Bydgoszczy
}

Agnieszka Kamyk-Wawryszuk ${ }^{* * *}$ (iD https://orcid.org/0000-0002-0545-6416

Uniwersytet Kazimierza Wielkiego w Bydgoszczy

\section{Karmienie piersią dziecka w miejscach publicznych a postawy kobiet i mężczyzn - komunikat $\mathrm{z}$ badań}

\begin{abstract}
Streszczenie: Przewodnim tematem niniejszego artykułu jest karmienie naturalne w miejscach publicznych. Na początku zostało opisane karmienie piersią w aspekcie psychologicznym i społecznym. Następnie wyjaśniono zjawisko postaw. Artykuł stanowi komunikat $\mathrm{z}$ badań nad postawami kobiet i mężczyzn wobec karmienia piersią w miejscach publicznych.
\end{abstract}

Słowa kluczowe: karmienie piersią, miejsce publiczne, postawy

* Agnieszka Hamerlińska - neurologopeda, specjalistka w zakresie onkologopedii, psycholog sp. kliniczny, prowadzi stronę internetową onkologopeda.pl, pracuje w Centrum Terapii Dobra Mowa, zainteresowania badawcze koncentruje wokół zaburzeń mowy i czynności prymarnych o podłożu onkologicznym i neurologicznym u dzieci oraz dorosłych.

** Emilia Kotlęga - pedagog, logopeda, uczestniczka Akademickiego Centrum Kreatywności.

${ }^{* * *}$ Agnieszka Kamyk-Wawryszuk - pedagog specjalny, logopeda, surdopedagog, tyflopedagog, terapeuta pedagogiczny, prowadzi terapię dzieci z zaburzeniami w rozwoju, zainteresowania badawcze koncentruje wokół wspierania rozwoju i edukacji dzieci z chorobami rzadkimi oraz ultra rzadkimi. 


\section{Wprowadzenie}

Kobietom, które zostają matkami, zalecane jest karmienie piersią. Dla rozwoju dziecka ten sposób karmienia jest bardzo korzystny, ponieważ między innymi: uodparnia, wspomaga pracę przewodu pokarmowego, usprawnia narządy jamy ustnej, kształtuje prawidłowy tor oddychania, przyczynia się do pogłębiania więzi z matką ${ }^{1}$. Zauważa się, że mimo wielu walorów i początkowych deklaracji przez ciężarne o chęci karmienia piersią, często po porodzie wiele matek podejmuje decyzję o karmieniu mieszankami sztucznymi ${ }^{2}$. Obecnie wskazane jest, aby odżywianie noworodka i niemowlęcia do szóstego miesiąca życia odbywało się na tzw. zawołanie, czyli wtedy, kiedy zauważane są oznaki głodu ${ }^{3}$. Oznacza to, że matka decydująca się na karmienie piersią, zmuszona jest do podawania jej niezależnie od okoliczności i miejsca pobytu. Fundacja Promocji Karmienia Piersią we współpracy m.in. z Nutropharmą rozpoczęły kampanię ogólnopolską związaną z promowaniem karmienia piersią w miejscach publicznych. W restauracjach, kościołach, galeriach kobiecie może być trudno karmić piersią, ponieważ czynność ta, w tych miejscach uznawana jest za niestosowną ${ }^{4}$. By karmienie naturalne w miejscach publicznych zyskało większą przychylność, w 2018 roku rozpoczęła się kampania „Koniec zabawy w chowanego”, do której przyłączyło się wielu przedstawicieli szpitali, jak i uczelni wyższych ${ }^{5}$. Zaczęto zabiegać o większą akceptację dla karmienia naturalnego w miejscach publicznych.

\section{Karmienie piersią - tworzenie relacji matka-dziecko i wspieranie rozwoju dziecka}

Mleko kobiece jest naturalnym pokarmem dla noworodków i niemowląt, całkowicie zaspokaja potrzeby dziecka ${ }^{6}$. Jego skład jest unikalny, ciągle się zmienia w zależności od okresu laktacji ${ }^{7}$. Fenomen mleka kobiecego wynika z jego składu: swoistego gatunkowo, a zarazem zmiennego, indywidualnie dostosowanego do dojrzałości

${ }^{1}$ A. Serwatowska-Bargieł, D. Chrzanowska-Liszewska, A. Łada (red.), Szkoła karmienia piersia, Poradnik o karmieniu naturalnym przygotowany we współpracy ze specjalistami $w$ dziedzinie laktacji, pediatrii i neurologopedii, Lovi, 2007, https://lovi.pl/lib/upload/files/pdf/Szkola karmienia piersia final.pdf (dostęp 8.04.2018).

2 A. Bień, A. Kozak, E. Rzońca, S. Stadnicka, Opinie i postawy kobiet wobec karmienia piersia, „Education, Health and Sport”, nr 7(8)/2017, s. 1258-1271.

${ }^{3}$ K. Mikiel-Kostyra, Jak karmić piersią?, [w:] A. Chybicka, A. Dobrzańska, J. Szczapa, J. Wysocki (red.), Pierwsze 2 lata życia dziecka. Przewodnik dla rodziców. Jak dbać o rozwój, pieleggnować i zapobiegać chorobom, Medycyna Praktyczna, Kraków 2012.

${ }^{4}$ https://konieczabawywchowanego.pl/o-kampanii (dostęp: 17.09.2018).

${ }^{5}$ https://konieczabawywchowanego.pl/vademecum-karmienia-piersia (dostęp: 17.09.2018).

${ }^{6}$ http://www.euro.who.int/ data/assets/pdf file/0015/120318/E74173.pdf(dostęp: 17.09.2018).

7 S. Kitzinger, Karmienie piersia, Państwowy Zakład Wydawnictw Lekarskich, Warszawa 1983, s. 16. 
i aktualnych potrzeb karmionego nim dziecka ${ }^{8}$. Mimo że powszechnie promuje się ten sposób odżywiania niemowląt, dużo kobiet rezygnuje z niego na poczet karmienia sztucznego. Według Światowej Organizacji Zdrowia (WHO) optymalnym czasem trwania karmienia jest okres 6 miesięcy. W tym czasie nie ma konieczności wprowadzania dziecku dodatkowych pokarmów. Po 6 miesiącu należy natomiast wzbogacić dietę o kolejne produkty.

Karmienie naturalne w ostatnich latach stało się przedmiotem zainteresowań również psychologów, którzy podkreślają znaczenie karmienia piersią dla rozwoju emocjonalnego dziecka9. Proces ten stwarza niepowtarzalną, pozytywną więź między matką a dzieckiem, co kształtuje dobre relacje w całej rodzinie ${ }^{10}$. W metaanalizie przeprowadzonej przez Andersona i wsp. (1999) wykazano wynik wyższy o 3,2 punktu $\mathrm{w}$ testach poznawczych wykonanych $\mathrm{u}$ dzieci karmionych piersią w porównaniu z dziećmi karmionymi sztucznie, uwzględniając wartości IQ u matki. Wykazano też lepszy rozwój poznawczy już od 6 miesiąca, który utrzymywał się przez cały okres dzieciństwa oraz okres dojrzewania. Dzieci o małej masie urodzeniowej zyskiwały na karmieniu piersią więcej (5,2 punktu) niż dzieci o prawidłowej masie urodzeniowej $(2,7 \text { punktu })^{11}$. Według badań Evenhouse, Reillly (2005) karmienie piersią, niezależnie od jego długości, wpływa znacząco na zwiększenie punktacji w teście na inteligencję (Peabody Picture Vocabulary Test) ocenianym w wieku dojrzewania odpowiednio o 1,7 i 2,4 punktu między rodzeństwem i rodzinami. Różnica ta była istotna statystycznie $^{12}$.

Również matce karmienie piersią daje ogromne korzyści. Czuje się ona potrzebna, wie, że daje swojemu dziecku to, co najlepsze. Wydzielana oksytocyna podczas karmienia sprzyja właściwej opiece i nawiązaniu prawidłowych relacji z dzieckiem oraz zmniejszenie napięcia i stresu u matki. Jak opisała Justyna Jasik, kobiety, które z różnych przyczyn nie mogą karmić naturalnie, mogą odczuwać smutek, rozżalenie, często także postrzegają siebie jako „wyrodne matki”'³.

${ }^{8}$ U. Bernatowicz-Łojko, J. Błeszyński, A. Studniczek, M. Twardo, A. Wesołowska, Karmienie naturalne jako element wsparcia matki/rodziny i rozwoju dziecka - znaczenie banku mleka kobiecego, [w:] K. Kaczorowska-Bray, S. Milewski (red.), Wczesna interwencja logopedyczna, Harmonia Universalis, Sopot 2016.

9 B. Rocławski, W. Fedorowska, B. Wardowska, Wczesne uwarunkowania rozwoju mowy. Wywiad biologiczno-środowiskowy, Glottispol, Gdańsk 1995, s. 48.

10 A. Banaszkiewicz, M. Nehrig-Gugulska, M. Żukowska-Rubik, M. Nagadowska, M. Postolski, Karmienie piersią. Skrypt dla studentów medycyny, Komitet Upowszechniania Karmienia Piersią, Warszawa 2002, s. 7.

${ }^{11}$ J.W. Anderson, B.M. Johnstone, D.T. Remley, Breast-feeding and cognitive development: a meta-analysis, „Am J Clin Nutr” 1999, s. 35.

${ }^{12}$ E. Evenhouse, S. Reilly, Improved estimates of the benefits of breastfeeding using sibling comparisons to reduce selection bias, „Health Serv Res” 2005, s. 802.

${ }^{13} \mathrm{~J}$. Jasik, Karmienie naturalne - cenny dar i kamień milowy opieki nad noworodkiem, „Rocznik Lubuski” 2014, t. 40, cz. 2, s. 247-259. 


\section{Społeczny aspekt karmienia naturalnego}

Obecnie prowadzone są badania, które rozszerzają problematykę karmienia piersią o kwestię społeczną. Zagadnienia te zostały opracowane w raporcie Karmienie piersią w Polsce. Raport 2015 ${ }^{14}$. Wynika $\mathrm{z}$ niego, że Polki wyrażają chęć karmienia swojego dziecka naturalnie (aż 98\% mam zaczyna karmić swoje dzieci piersią po porodzie ${ }^{15}$. Co więcej, Polska jest w czołówce 10 krajów w Europie z wysokim odsetkiem rozpoczynania karmienia piersią, ale pomimo tego liczba matek karmiących piersią drastycznie spada. Można zauważyć, że już w pierwszym miesiącu od narodzin dziecka, a także po 6 tygodniu, karmi naturalnie tylko $46 \%$ matek.

Wyniki w Polsce, związane z karmieniem piersią, są niezadowalające, biorąc pod uwagę nieuzyskiwanie szeregu korzyści zdrowotnych, ekonomicznych i społecznych. Aby to się zmieniło, należałoby edukować zarówno personel medyczny, jak i rodziców w kwestiach laktacji. Potwierdzają to dane, że aż 36\% kobiet doświadczyło sytuacji, że ani ginekolog, ani położna nie rozmawiali i nie przygotowali ich do karmienia piersią ${ }^{16}$. Mimo że karmienie naturalne jest bardziej rekomendowane przez opinię społeczną, aniżeli karmienie sztuczne, to kobiety często borykają się z trudnościami wynikającymi z żywienia dziecka w miejscach innych niż dom. Jak zauważa Kitzinger, w europejskiej kulturze piersi są traktowane jako obiekt erotyczny, a karmienie piersią bywa traktowane jako nieestetyczne oraz niekulturalne, negatywnie postrzegane $\mathrm{w}$ miejscu publicznym. W sytuacji, gdy kobieta w miejscu publicznym da dziecku pierś, może spotkać się z gwałtownym sprzeciwem lub nawet być usunięta $z$ hotelowego foyer czy innego miejsca publicznego ${ }^{17}$. Przeciwnie jest, gdy dziecko jest publicznie karmione $z$ butelki. Nie jest to akt gorszący, wstydliwy ani dla matki, ani dla społeczeństwa. I tu pojawia się pewien paradoks wynikający z promowania naturalnego karmienia z jednoczesnym odrzuceniem go przez część społeczeństwa.

W związku z tym, że zdarzają się w Polsce negatywne zachowania wobec matek karmiących piersią w miejscach publicznych, rozwinęły się kampanie „Karmiące cyce na ulice” oraz „Koniec zabawy w chowanego”, promujące karmienie naturalne, w miejscu gdzie jest taka potrzeba, a nie przyzwolenie społeczne ${ }^{18}$. Matki zdecydowały się więc wyjść na ulicę, aby przekonać Polaków do swoich racji. Podkreślają, iż absurdem jest to, że kobietom karmiącym piersią, czyli wykonującym najbardziej naturalny gest, mówi się o tym, żeby się „nie obnażały” lub „poszły do toalety”. Powo-

${ }^{14}$ Karmienie piersia w Polsce. Raport 2015, Kampania Mleko Mamy Rządzi, http://femaltiker.pl/wp-content/uploads/2015/05/Raport Karmienie Piersia w Polsce 20151.pdf (dostęp: 7.04.2018).

${ }^{15}$ Należy jednak zwrócić uwagę na to, że być może są one nieco przymuszane do tej formy karmienia podczas pobytu w szpitalu. Opuszczając z dzieckiem szpital, bardzo często rezygnują z karmienia naturalnego na rzecz sztucznego.

${ }^{16}$ E. Evenhouse, S. Reilly, dz. cyt., s. 14.

${ }_{17}$ S. Kitzinger, dz. cyt., s. 172.

${ }^{18}$ https://konieczabawywchowanego.pl/o-kampanii (dostęp: 17.09.2018). 
duje to duże wzburzenie wśród matek, które podkreślają, że toaleta nie jest miejscem do przyjmowania posiłków, żaden dorosły nie wybrałby go, aby zjeść obiad. Niestety w miejscach publicznych brakuje miejsc, w których można byłoby nakarmić dziecko. Główną pomysłodawczynią akcji „Karmiące cyce na ulice” jest Hanna Li, która założyła grupę dyskusyjną na Facebooku. Przekonuje ona, że matki mają prawo karmić piersią wszędzie w przestrzeni publicznej, a dzieci mają prawo do najlepszego pokarmu, jaki można im dać. Jest to istotny element promocji zdrowia. Li uważa, że karmienie piersią nie powinno ograniczać się tylko do pierwszych 6 miesięcy i powołuje się na papieża Franciszka, który zachęca do karmienia piersią w kościele, w katolickich wspólnotach. Protest kobiet spotkał się ze skrajnymi komentarzami. Z jednej strony zyskały uznanie, zebrały wiele pochwał odnośnie swoich działań, z drugiej jednak rozpoczęła się fala krytyki ${ }^{19}$.

\section{Postawy - wyjaśnienie pojęcia}

Termin „postawa” został użyty po raz pierwszy przez filozofów Herberta Spencera i Aleksandra Baina, którzy zdefiniowali go następująco: stan gotowości do słuchania, uczenia się czegoś, stan, który jest warunkiem przyswojenia sobie prawdziwej wie$\mathrm{dzy}{ }^{20}$. We wczesnych teoriach psychologicznych, których twórcami byli między innymi T. Lange, A. Ribot, C. Fere, termin ten był definiowany jako postawa motoryczna stanowiąca podstawę procesów spostrzeżeniowych, procesów uwagi czy wybiórczej świadomości ${ }^{21}$. Z kolei Milton J. Rosenberg rozumie przez postawę strukturę złożoną z elementów poznawczych, a dokładniej ze zbioru przekonań dotyczących możliwości realizowania pewnych wartości przez przedmiot postawy i że elementy afektywne pozostają ze sobą w stałym związku i harmonii ${ }^{22}$. Polski badacz Stefan Nowak uważa, że postawa odnosi się do określonego przedmiotu i składa się z elementów poznawczych, emocjonalno-oceniających i z elementów behawiorystycznych, dyspozycji do zachowania się wobec przedmiotu i klasy przedmiotów ${ }^{23}$. Obiektem postawy może

${ }^{19}$ Ł. Gdak, Karmiace cyce na ulice: Młode mamy spotkały się w parku Wieniawskiego, „Głos Wielkopolski”, http://www.gloswielkopolski.pl/wiadomosci/poznan/a/karmiace-cyce-na-ulice -mlode-mamy-spotkaly-sie-w-parku-wieniawskiego,10059706/ (dostęp: 1.04.2018); K. Stańczyk, Kontrowersyjna akcja „Karmiące cyce na ulice”. Chca przekonać mamy do karmienia piersia w miejscach publicznych, http://www.mjakmama24.pl/niemowle/dieta-niemowlaka/karmiace-cyce-na -ulice-wyszly-na-ulice-zeby-przekonac-mamy-do-karmienia-w-miejscach-publicznych, 5565931. html (dostęp: 2.06.2016).

${ }^{20}$ G.W. Allport, Attiudes, [w:] Handbook of social psychology, Worcester 1935.

${ }^{21}$ S. Mika, Psychologia społeczna, Państwowe Wydawnictwo Naukowe, Warszawa 1987, s. 111.

${ }^{22}$ M.J. Rosenberg, Cognitive reorganizations in response to the hypnotic reversal of attitudinal affect, [w:] C.W. Backman, P.S. Second (red.), Problems in social psychology, McGraw-Hill, New York 1962, s. 89.

${ }^{23}$ S. Nowak, Pojęcie postawy w teoriach i stosowanych badaniach społecznych, [w:] S. Nowak (red.), Teorie postaw, Państwowe Wydawnictwo Naukowe, Warszawa 1973, s. 2. 
być każda rzecz, którą dana osoba rozróżnia lub o której myśli, czy to konkretna (np. pizza), czy abstrakcyjna (np. wolność słowa), rzecz nieożywiona (np. samochód sportowy), osoba (Wisława Szymborska) lub też grupa (np. politycy konserwatywni, cudzoziemcy) $)^{24}$. Postawa wyraża sumaryczną ocenę obiektu postawy. Komponenty tej sumarycznej oceny mogą mieć charakter emocjonalny, poznawczy i behawioralny. Mogą one obejmować każdy typ informacji, który ma implikacje wartościujące ${ }^{25}$ (rys. 1).

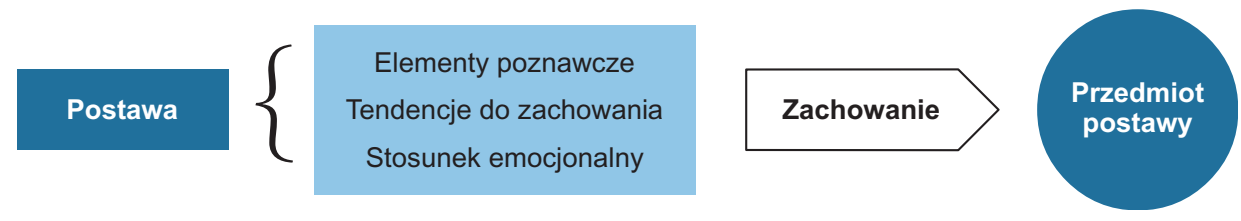

Rysunek 1. Struktura postawy

Źródło: S. Mika, Psychologia społeczna, Państwowe Wydawnictwo Naukowe, Warszawa 1987, s. 117.

Komponent emocjonalny określa reakcje emocjonalne wobec przedmiotu postawy (np. innej osoby lub problemu społecznego). Komponent poznawczy to myśli i przekonania o przedmiocie postawy. Z kolei behawioralny, to działania, czyli dające się zaobserwować zachowanie wobec przedmiotu postawy ${ }^{26}$.

Zauważa się silny związek postaw z zachowaniem. Wskaźnikiem zachowania może być pojedyncze działanie. Postawa wobec jakiegoś określonego działania skierowanego na obiekt jest zwykle bardziej konkretna od ogólnej postawy wobec danego obiektu, dlatego pierwsza jest dobrym predykatorem działania w porównaniu z drugą. Związek między postawą a zachowaniem jest silny wtedy, gdy oba te pojęcia są mierzone na tym samym poziomie szczegółowości ${ }^{27}$. Istnieją liczne czynniki, które mogą wpływać na to, czy będzie istniał związek między zachowaniem a postawą, rozumianą jako wewnętrzna struktura wymienionych wyżej procesów. Są to czynniki o charakterze osobowościowym oraz czynniki sytuacyjne ${ }^{28}$. Wysoka korelacja między zachowaniem nie musi też oznaczać, że postawy powodują zachowanie ${ }^{29}$.

${ }^{24}$ G. Böhner, M. Wänke, Postawy i zmiany postaw, Gdańskie Wydawnictwo Psychologiczne, Gdańsk 2004, s. 17.

25 Tamże, s. 29.

${ }^{26}$ E. Aronson, T.D. Wilson, R.M. Akert, Psychologia społeczna. Serce i umysł, Zysk i s-ka, Poznań 1997, s. 314.

${ }^{27}$ G. Böhner, M. Wänke, dz. cyt., s. 252.

${ }^{28}$ S. Mika, dz. cyt., s. 125.

${ }^{29}$ G. Böhner, M. Wänke, dz. cyt., s. 252. 


\section{Postawy kobiet i mężczyzn wobec karmienia piersią w miejscach publicznych - uwagi metodologiczne i wyniki badań własnych}

Przedmiotem badań własnych uczyniono postawy kobiet i mężczyzn wobec karmienia piersią w miejscach publicznych, a za cel badań przyjęto opisanie tychże postaw. Ustalono dwa pytania główne:

1. Jakie są postawy kobiet i mężczyzn do karmienia naturalnego?, do którego sformułowano pytania szczegółowe:

1.1. Czy badane kobiety i badani mężczyźni chcieliby, aby ich dziecko było karmione naturalnie?

1.2. Czy zdaniem kobiet i mężczyzn karmienie piersią jest tematem tabu?

1.3. Czy karmienie piersią wśród badanych wywołuje negatywne odczucia?

2. Jakie są postawy kobiet i mężczyzn wobec karmienia piersią w miejscach publicznych?, do którego przypisano pytania szczegółowe:

2.1. Czy zdaniem kobiet i mężczyzn kobieta karmiąca naturalnie może swobodnie wykonywać tę czynność w miejscach publicznych?

2.2. Czy według kobiet i mężczyzn w miejscach publicznych powinny znajdować się specjalne pomieszczenia do karmienia piersią?

2.3. Czy w opinii kobiet i mężczyzn matka karmiąca piersią obnaża intymne części ciała?

Badania własne zostały przeprowadzone za pomocą sondażu diagnostycznego, do którego wykorzystano ankietę. Uczestniczyło w nich 100 osób, 50 kobiet i 50 mężczyzn. Ankietowani sami zgłaszali chęć wypełnienia kwestionariusza. Najmłodsza osoba miała 18 lat, najstarsza 40. Wśród kobiet, $30 \mathrm{z}$ nich ma wykształcenie wyższe, 19 wykształcenie średnie, jedna osoba ma zasadnicze zawodowe. Pośród mężczyzn 20 ma wykształcenie wyższe, 27 wykształcenie średnie, 1 zasadnicze zawodowe oraz 2 gimnazjalne.

Pierwsze pytanie główne dotyczyło stosunku kobiet i mężczyzn do karmienia piersią. Pierwsze szczegółowe pytanie wiązało się z nastawieniem wobec karmienia naturalnego. Zapytano respondentów o to, czy chcieliby, aby ich dziecko było karmione naturalnie (wykres 1). 


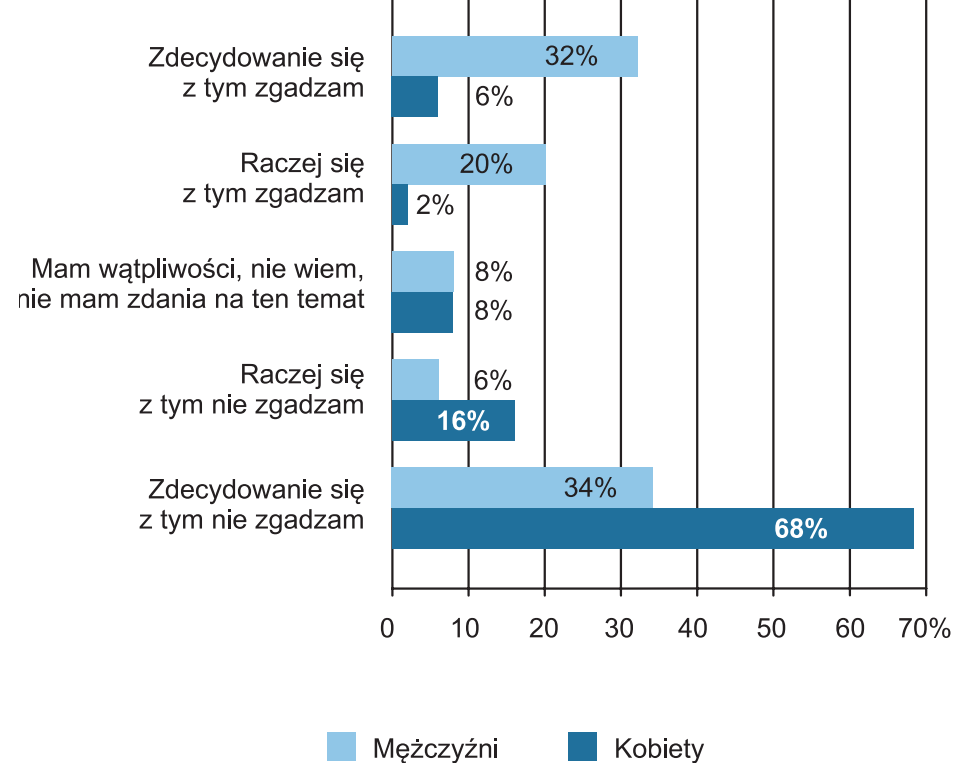

Wykres 1. Nastawienie wobec karmienia własnego dziecka piersią Źródło: opracowanie własne.

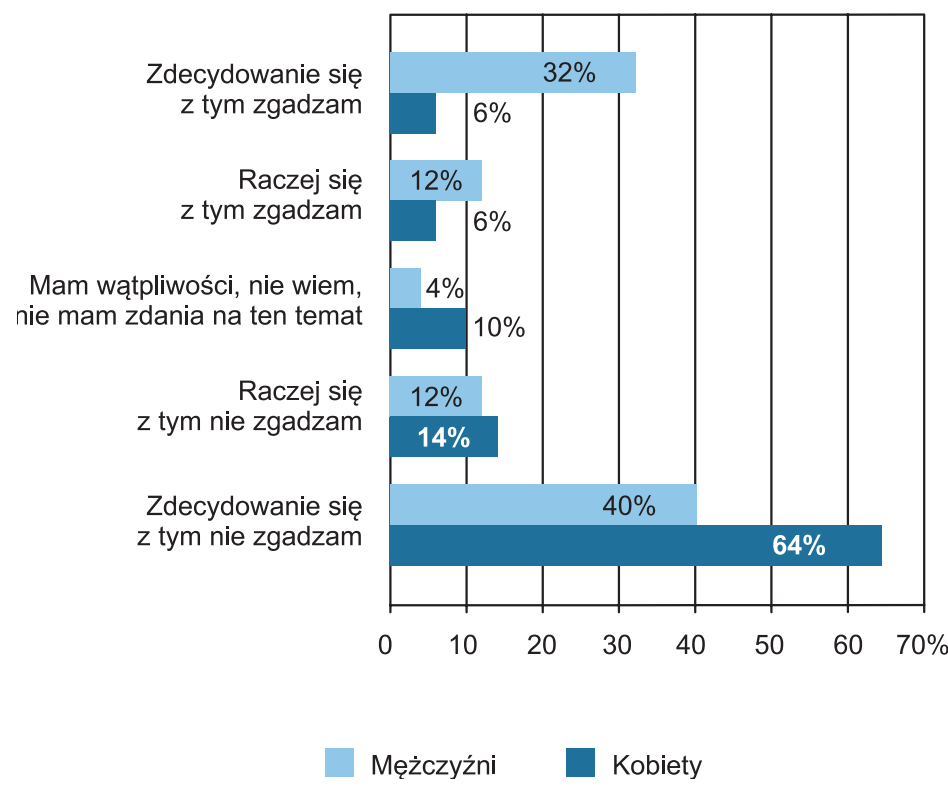

Wykres 2. Karmienie piersią stanowi temat tabu

Źródło: opracowanie własne.

Zaledwie 6\% kobiet i aż 32\% mężczyzn zadeklarowało, że zdecydowanie chciałoby, aby ich dziecko było karmione piersią. Natomiast większość ankietowanych kobiet 
(68\%) zdecydowanie uważa, że nie chciałoby, aby ich dziecko było karmione naturalnie. Tego samego zdania jest 34\% mężczyzn.

Uzyskane wyniki wskazują na to, że większości osób spośród badanych nie zależy na tym, aby dziecko było karmieniu piersią. Matki wcześnie rezygnują z karmienia piersią i wybierają karmienie z wykorzystaniem butelki.

Kolejne pytania wiązało się z wyrażeniem opinii, czy karmienie piersią stanowi temat tabu (wykres 2).

Zdecydowana większość kobiet, aż 64\% uważa, że temat karmienia piersią jest wciąż tematem tabu. Podobnie uważają mężczyźni (40\%). Tylko 6\% kobiet i aż 32\% mężczyzn uznało, że opisywany problem nie powinien wiązać się ze wstydem i powinno się otwarcie o nim mówić.

Wyniki wskazują na to, że kobiety być może odczuwają wstyd, rozmawiając na temat karmienia piersią. Wydawać się może, że jest to dla nich strefa intymna, wokół której nie powinno się zbyt wiele rozmawiać. Warto jednak zwrócić uwagę, że mężczyźni są bardziej otwarci na rozmawianie o karmieniu piersią.

Zapytano także o to, czy karmienie piersią może wywoływać negatywne uczucia. Wyniki prezentuje wykres 3.

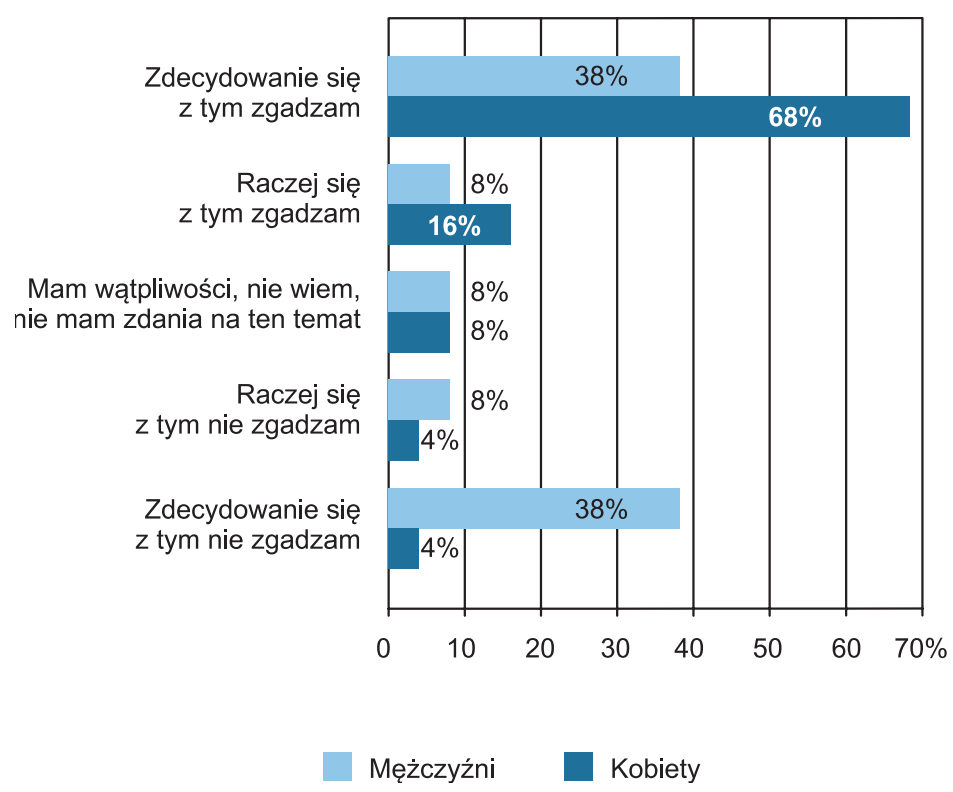

Wykres 3. Odczuwanie negatywnych uczuć a karmienie piersią

Źródło: opracowanie własne.

Zdecydowana większość kobiet (68\%) uważa, że karmienie piersią jest niesmaczne, wzbudza w nich negatywne uczucia. Zaledwie $4 \%$ kobiet zaprzecza temu stwierdzeniu, 4\% raczej się z nim nie zgadza. Inaczej wypowiadają się mężczyźni, którzy w 38\% uważają, że zdecydowanie nie zgadzają się z powyższym zdaniem, 8\% raczej 
się nie zgadza, $8 \%$ nie ma zdania, 38\% się z tą tezą zgadza, $8 \%$ raczej się zgadza. Większość mężczyzn uważa, że karmienie piersią nie wywołuje negatywnych emocji.

Na podstawie uzyskanych wyników można zauważyć, że kobiety mają trudność w akceptacji karmienia naturalnego. Większość jest skłonna stwierdzić, że jest to zjawisko nawet niesmaczne - co oznacza, że kojarzy się z negatywnymi emocjami. Wyniki te znajdują odzwierciedlenie w Raporcie z 2015 roku nt. karmienia piersią w Polsce, w którym wśród powodów rezygnacji z karmienia wymieniono: ból w trakcie karmienia, niewygodę, konieczność obecności przy dziecku i obawę o deformację piersi $^{30}$.

Drugie pytanie główne wiązało się już z badanym zjawiskiem, za jaki obrano karmienie naturalne w miejscach publicznych. Zadano pytanie o to, czy kobiety karmiące piersią mogą wykonywać tę czynność swobodnie w miejscach publicznych (wykres 4).

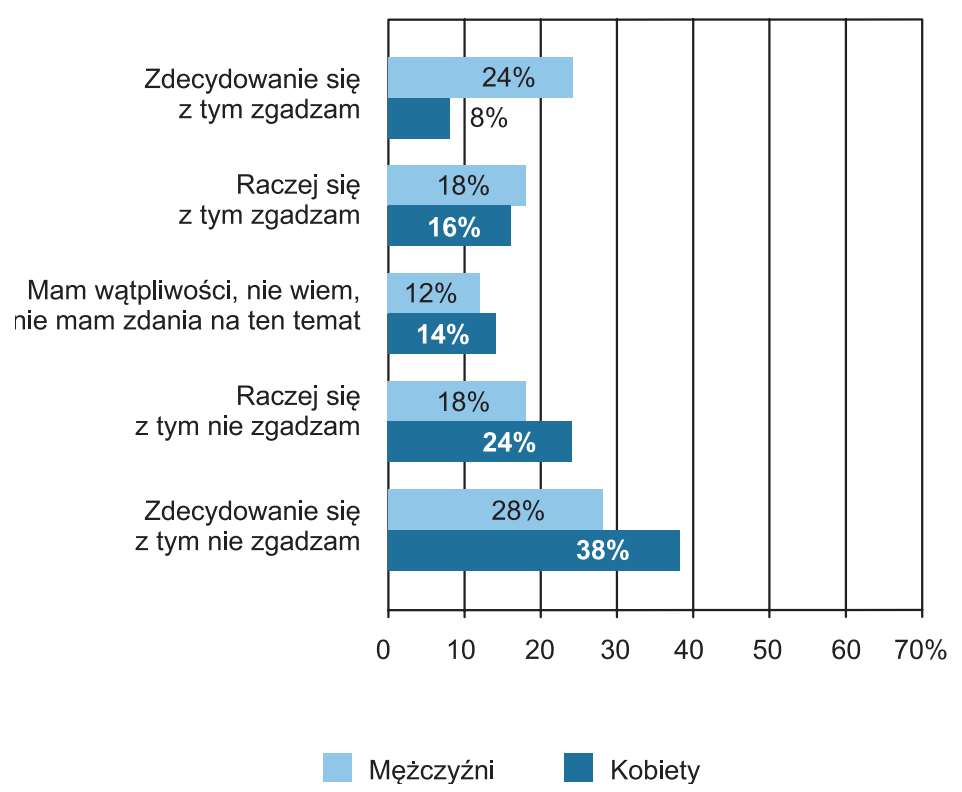

Wykres 4. Swobodne karmienie piersią w miejscach publicznych w opinii kobiet i mężczyzn

Źródło: opracowanie własne.

W opinii 38\% kobiet oraz 28\% mężczyzn kobieta nie powinna czuć swobody podczas karmienia naturalnego w miejscu publicznym. Mimo tego, że większość badanych jest przeciwna karmieniu piersią w miejscu publicznym, warto zwrócić uwage na to, że na odczuwanie większej swobody pozwalają mężczyźni - aż 24\% mężczyzn, gdzie za swobodą opowiedziało się tylko $8 \%$ badanych kobiet.

${ }^{30}$ http://femaltiker.pl/wp-content/uploads/2015/05/Raport Karmienie Piersia w Polsce 20151.pdf (dostęp: 17.09.2018). 
Uzyskane wyniki potwierdzają konieczność prowadzenia kampanii „Karmiące cyce na ulice” czy też „Koniec zabawy w chowanego”, ponieważ być może w społeczeństwie jest zbyt niski poziom świadomości, że karmienie naturalne w miejscu publicznym jest wprost wskazane, a kobiety karmiące powinny być przede wszystkim bardziej akceptowane niż odrzucane, czy też poniżane.

Kolejne pytanie wiązało się z organizowaniem specjalnych miejsc do karmienia naturalnego w centrach handlowych, dworcach, parkach. Wyniki przedstawia wykres 5.

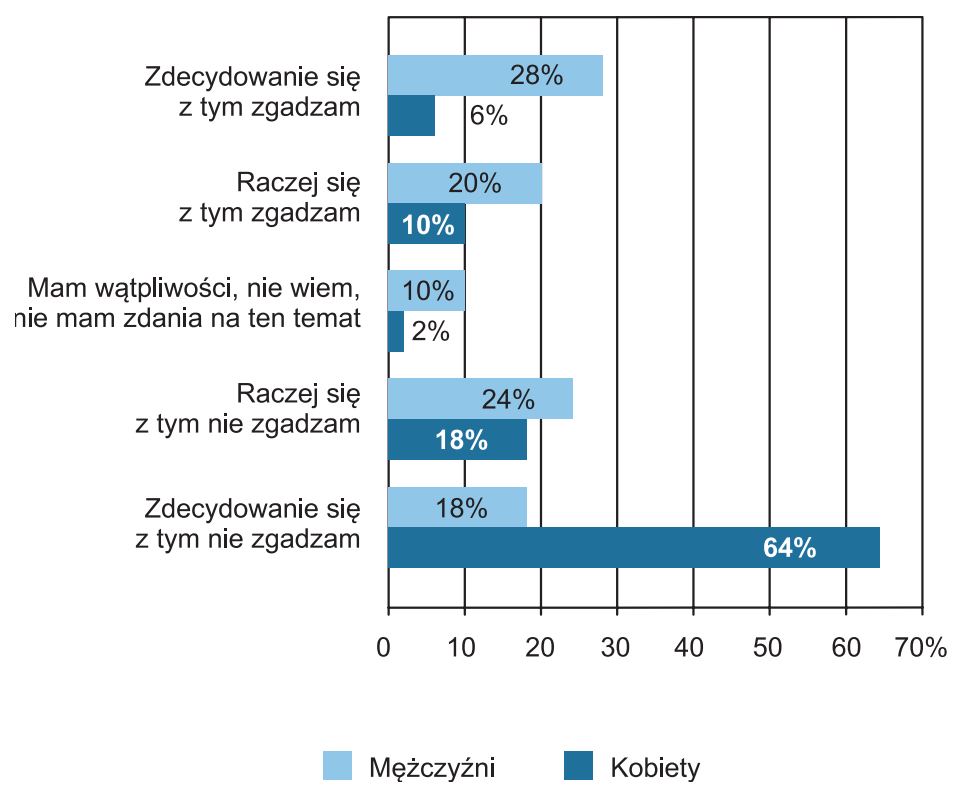

Wykres 5. Organizowanie specjalnych miejsc do karmienia piersią w opinii kobiet i mężczyzn

Źródło: opracowanie własne.

Spośród badanych kobiet aż 64\% zdecydowanie zaprzecza konieczności powstawania miejsc dla karmiących matek. $18 \%$ raczej się z tym nie zgadza, $2 \%$ nie ma zdania. Całkowicie popiera tę inicjatywę zaledwie $6 \%$ ankietowanych kobiet. Poparciem dla tworzenia miejsc do karmienia wykazało się $10 \%$ badanych kobiet. Bardziej przychylni do tworzenia specjalnych miejsc dla matek są mężczyźni. $28 \%$ z nich zdecydowanie afirmuje osobne pomieszczenia, a $20 \%$ raczej się z tym zgadza. $10 \%$ zapytanych mężczyzn nie ma zdania na ten temat. 18\% neguje konieczność wydzielania takich stref, a $24 \%$ raczej nie widzi dla nich konieczności.

Dzięki kampanii „Koniec zabawy w chowanego” zostały opracowane wskazówki do karmienia naturalnego w miejscach publicznych, również ze wskazaniem do tworzenia specjalnych miejsc do karmienia. Jednakże podkreśla się, że kobieta karmiąca piersią może wykonywać tę czynność wszędzie. Specjalne pomieszczenia mają służyć 
jedynie zaspokojeniu poczucia bezpieczeństwa dziecku i zagwarantować matce oraz dziecku ciszę, spokój.

Kolejne pytanie dotyczyło tego, czy karmienie piersią w miejscu publicznym kojarzone jest z obnażaniem kobiecego ciała. Wyniki przedstawia wykres 6 .

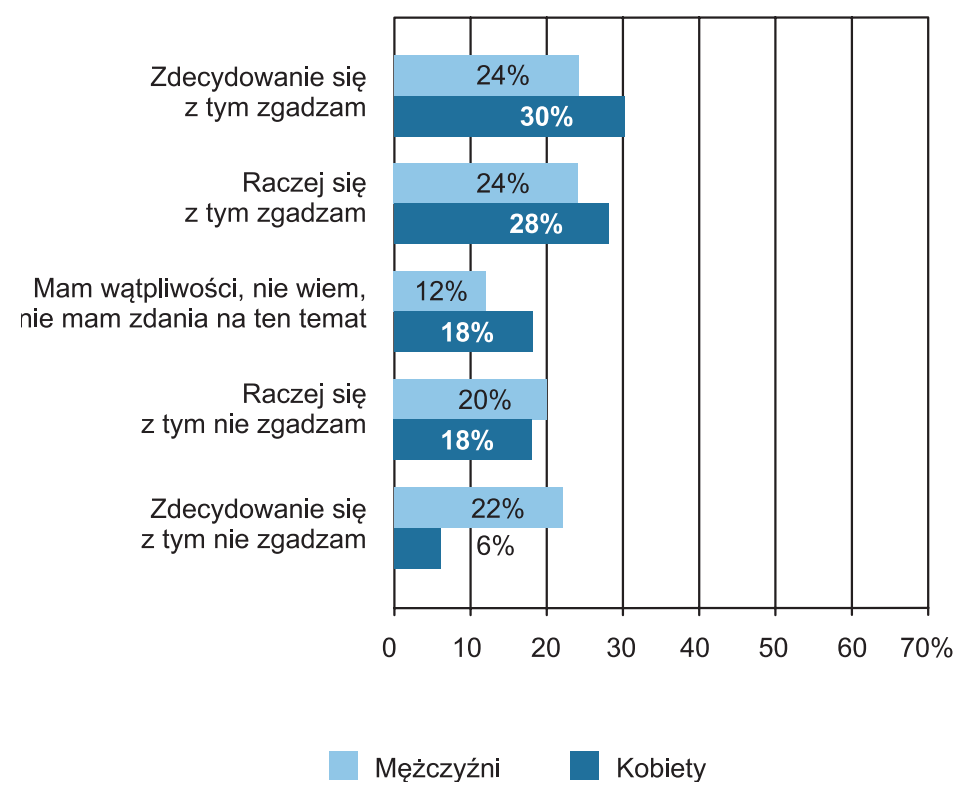

Wykres 6. Karmienie piersią a obnażanie ciała

Źródło: opracowanie własne.

Zdaniem 30\% kobiet i 24\% mężczyzn, matki karmiące piersią odbierane są jako obnażające intymne części ciała. 28\% kobiet i 24\% mężczyzn raczej się z tym zgadza. Zdania na ten temat nie ma 18\% kobiet oraz 12\% mężczyzn. 28\% kobiet i 20\% mężczyzn raczej nie widzi w tym konfidencjonalnego podtekstu, a 6\% kobiet i $22 \%$ mężczyzn zdecydowanie zaprzecza, iż karmiąca matka miałaby pokazywać intymne części swojego ciała.

Można zauważyć, że karmienie piersią wciąż utożsamiane jest z obnażaniem ciała. Jednakże warto podkreślić, że z założenia celem karmienia naturalnego jest nakarmienie dziecka.

\section{Wnioski i podsumowanie}

Na podstawie przeprowadzonych badań w grupie stu osób zauważyć można, że postawa kobiet i mężczyzn wobec karmienia naturalnego jest raczej negatywna. Postawa ta nie dotyczy tylko kwestii karmienia w miejscach publicznych, ale w ogóle samej czynności karmienia piersią: 
- Większość badanych kobiet przyznało, że nie zamierza karmić piersią swojego dziecka.

- Niemalże taka sama liczba badanych mężczyzn jest przeciwna karmieniu naturalnemu swojego dziecka, co grupa mężczyzn chcących, aby ich dziecko było karmione piersią.

- Zdaniem badanych karmienie piersią stanowi wciąż temat tabu. Szczególnie wśród kobiet jest to temat wstydliwy.

- Mężczyźni są bardziej otwarci na karmienie piersią w miejscu publicznym niż kobiety.

- Większość kobiet nie widzi potrzeby tworzenia specjalnych miejsc do karmienia piersią w miejscach publicznych. Mężczyźni są bardziej przychylni, aby powstawały takie miejsca.

- Zdecydowana większość kobiet i mężczyzn przyznała, że kobieta karmiąca piersią w miejscu publicznym nie powinna się czuć z tym swobodnie.

- Większości badanym karmienie piersią w miejscu publicznym kojarzy się z obnażaniem kobiecego ciała.

Czynność karmienia piersią jest zjawiskiem naturalnym. W okresie noworodkowym i niemowlęctwa ta forma odżywiania jest najbardziej pożądaną i wskazywaną przez m.in. lekarzy, logopedów, położne. O korzyściach karmienia naturalnego mówi się dość powszechnie. Jednakże zbyt mało się mówi o akceptacji kobiet karmiących piersią w miejscach publicznych. Raczej rzadko ktoś chciałby się czuć represjonowany społecznie. Warto zwrócić uwagę na obecne trendy, gdzie ciało i seksapil odgrywają znacząca rolę w przekonaniach kobiet i mężczyzn, a karmienie piersią wydaje się prawdopodobnie mało pociągające.

Należałoby rozwinąć działania mające na celu wzrost akceptacji dla karmienia naturalnego, nawet w miejscach publicznych. Zarówno pedagodzy, logopedzi, psycholodzy, jak i lekarze powinni edukować się w tym zakresie, przekazując swoją wiedzę. Tylko dzięki temu karmienie naturalne stanie się priorytetem dla matek i ojców, a zyskają na tym zarówno oni, jak ich dzieci. Sugeruje się w przyszłości poszerzenie badań, których celem byłoby pogłębienie postawy wobec karmienia piersią, nie tylko w miejscach publicznych.

\section{Bibliografia}

Allport G.W., Attiudes, [w:] Handbook of social psychology, Worcester 1935.

Anderson J.W., Johnstone B.M., Remley D.T., Breast-feeding and cognitive development: a meta-analysis, „Am J Clin Nutr” 1999.

Aronson E., Wilson T.D., Akert R.M., Psychologia społeczna. Serce i umysł, Zysk i s-ka, Poznań 1997. 
Banaszkiewicz A., Nehrig-Gugulska M., Żukowska-Rubik M., Nagadowska M., Postolski M., Karmienie piersią. Skrypt dla studentów medycyny, Komitet Upowszechniania Karmienia Piersią, Warszawa 2002.

Bernatowicz-Łojko U., Błeszyński J., Studniczek A., Twardo M., Wesołowska A., Karmienie naturalne jako element wsparcia matki/rodziny i rozwoju dziecka - znaczenie banku mleka kobiecego, [w:] K. Kaczorowska-Bray, S. Milewski (red.), Wczesna interwencja logopedyczna, Harmonia Universalis, Sopot 2016.

Bień A., Kozak A., Rzońca E., Stadnicka S., Opinie i postawy kobiet wobec karmienia piersia, „Education, Health and Sport”, nr 7(8)/2017, s. 1258-1271.

Böhner G., Wänke M., Postawy i zmiany postaw, Gdańskie Wydawnictwo Psychologiczne, Gdańsk 2004.

Evenhouse E., Reilly S., Improved estimates of the benefits of breastfeeding using sibling comparisons to reduce selection bias, „Health Serv Res” 2005.

Gdak Ł., Karmiace Cyce na Ulice: Młode mamy spotkały się w parku Wieniawskiego, „Głos Wielkopolski”, http://www.gloswielkopolski.pl/wiadomosci/poznan/a/ karmiace-cyce-na-ulice-mlode-mamy-spotkaly-sie-w-parku-wieniawskiego,10059706/ (dostęp: 1.04.2018).

http://www.euro.who.int/ data/assets/pdf file/0015/120318/E74173.pdf (dostęp: 17.09.2018).

Karmienie piersia w Polsce. Raport 2015, Kampania Mleko Mamy Rządzi, http://femaltiker.pl/wp-content/uploads/2015/05/Raport Karmienie Piersia w Polsce 20151.pdf (dostęp: 7.04.2018).

Kitzinger S., Karmienie piersia, Państwowy Zakład Wydawnictw Lekarskich, Warszawa 1983.

Mika S., Psychologia społeczna, Państwowe Wydawnictwo Naukowe, Warszawa 1987.

Mikiel-Kostyra K., Jak karmić piersią?, [w:] A. Chybicka, A. Dobrzańska, J. Szczapa, J. Wysocki (red.), Pierwsze 2 lata życia dziecka. Przewodnik dla rodziców. Jak dbać o rozwój, pielegnować i zapobiegać chorobom, Medycyna Praktyczna, Kraków 2012.

Nowak S., Pojęcie postawy w teoriach i stosowanych badaniach społecznych, [w:] S. Nowak (red.), Teorie postaw, Państwowe Wydawnictwo Naukowe, Warszawa 1973.

Rocławski B., Fedorowska W., Wardowska B., Wczesne uwarunkowania rozwoju mowy. Wywiad biologiczno-środowiskowy, Glottispol, Gdańsk 1995.

Rosenberg M.J., Cognitive reorganizations in response to the hypnotic reversal of attitudinal affect, [w: C.W. Backman, P.S. Second (red.), Problems in social psychology, McGraw-Hill, New York 1962.

Serwatowska-Bargieł A., Chrzanowska-Liszewska D., Łada A. (red.), Szkoła karmienia piersią, Poradnik o karmieniu naturalnym przygotowany we wspótpracy ze specjalistami $w$ dziedzinie laktacji, pediatrii i neurologopedii, Lovi, 2007, https://lovi.pl/lib/upload/files/pdf/Szkola karmienia piersia final.pdf (dostęp: 8.04.2018). 
Stańczyk K., Kontrowersyjna akcja „Karmiące cyce na ulice”. Chca przekonać mamy do karmienia piersia w miejscach publicznych, http://www.mjakmama24.pl/ niemowle/dieta-niemowlaka/karmiace-cyce-na-ulice-wyszly-na-ulice-zeby -przekonac-mamy-do-karmienia-w-miejscach-publicznych,556 5931.html (dostęp: 2.06.2016).

\section{Breastfeeding in public places. Attitudes of women and men}

Abstract: This article concerns the attitudes of women and men towards natural feeding in public places. First, the psychological and social aspects of breastfeeding will be described. Second, attitudes towards breastfeeding will be explained. The article presents the results of research based on a sample of one hundred people.

Keywords: breastfeeding, public place, attitudes

\footnotetext{
About the authors: Agnieszka Hamerlińska - speech therapist, specialist in oncologopedics, clinical psychologist, runs the onkologopeda.pl website, works in the Center of Good Speech Therapy, research interests concentrate on speech disorders and primary activities of oncological and neurological basis in children and adults.

Emilia Kotlęga - pedagogue, speech therapist, participant of the Academic Center of Creativity.

Agnieszka Kamyk-Wawryszuk - special educator, speech therapist, surdopedagogist, pedagogical therapist, she conducts therapy of children with developmental disorders, research interests concentrate around supporting development and education of children with rare and ultra-rare diseases.
} 


\section{Pomiędzy rzeczywistością a mitologizacją. Recenzja książki Małgorzaty Stępnik, Outsiderzy, mistyfikatorzy, eskapiści w sztuce XX wieku. Studium postaw twórczych, WUMCS, Lublin 2016}

Małgorzata Stępnik - autorka książki Outsiderzy, mistyfikatorzy, eskapiści w sztuce XX wieku, wydanej w Lublinie w 2016 r. przez Wydawnictwo Uniwersytetu Marii Curie-Skłodowskiej podjęła się niełatwego zadania, chcąc przestudiować dwudziestowieczne postawy twórcze realnych i fikcyjnych artystów z pozycji filozofii i teorii sztuki.

Książka liczy 289 stron. Na podkreślenie zasługują jej walory estetyczne: intrygująca okładka zaprojektowana przez artystkę Kaję Renkas, a także szata graficzna każdej z części książki czy rzadko dziś spotykany kredowy papier wydania. Niewątpliwy atut publikacji stanowią wielobarwne i dopracowane ilustracje, uzupełniające erudycyjne refleksje i krytyczny dyskurs uprawiany przez autorkę. Wytrawny znawca i pasjonat sztuki będzie delektował się każdym opisem. Bogactwo przykładów odwołujących się do literatury światowej, jak również do świata filmu, plasuje tę książkę wysoko w zbiorze współczesnej polskiej humanistyki. Dla nowicjusza, czytelnika dopiero odkrywającego sztukę i jej teoretyczne aspekty, ta pozycja będzie wielkim wyzwaniem z uwagi na hermetyczny język, a także bogate dywagacje w przypisach, szeroki zakres odwołań do literatury naukowej, obcojęzyczne zwroty i liczne metafory. Książka będzie łatwiejsza do zrozumienia po wcześniejszym zapoznaniu się z sylwetkami omawianych jednostek działających w polu poezji i sztuk plastycznych.

Jasmina Al-Douri - mgr Katedry Edukacji Artystycznej Wydziału Nauk o Wychowaniu Uniwersytetu Łódzkiego, doktorantka Instytutu Pedagogiki Wydziału Nauk Społecznych Uniwersytetu Gdańskiego. 
Tytuł książki dobrze oddaje jej zawartość formalną i intelektualną. Autorka książki osiągnęła swój cel. Zabrała czytelnika do fascynującego świata artystycznego outsiderów, kreśląc ich motywacje twórcze, credo, strategie i mistyfikacje artystyczne.

Rozprawa składa się z dziewięciu rozdziałów, a każdy z nich jest osobną częścią, erudycyjnym esejem z pogranicza teorii sztuki, krytyki, estetyki. Te „próby”, jak nazywa je autorka, poświęcone są wybranym postaciom ze świata sztuki, ich osobowościom, postawom twórczym oraz szeroko pojętym biografiom. Autorka zaprasza czytelnika w fascynującą podróż intelektualną odsłaniając różne case study. Czyni to poprzez rekonstrukcję ich osobowości twórczych, dorobku artystycznego, wizji świata i siebie. Śledząc skomplikowane konstelacje osobowości twórczych, zawieszone między „znaną nam rzeczywistością a przestrzenią iluzji i fantazmatu”, nie wiemy, jakie kryterium doboru postaci przyświecało autorce. Całość stwarza wrażenie udanego okiełznania bogatego artystyczno-filozoficznego imaginarium odmieńców lokujących się gdzieś poza utartymi ujęciami historii literatury i sztuki oraz pomiędzy rzeczywistością a mitologizacją. Można mieć jednak zastrzeżenia do układu pracy, w którym nie zachowano linearnego porządku czasu, ani nie objawił się zrazu jasny zamysł porządkujący materiał. Momentami podążanie za tropami zostawionymi przez twórców przypomina drobiazgowe śledztwo. Prezentowane oblicza artystów płci żeńskiej i męskiej, różnią się od siebie, ale posiadają także cechy wspólne. W tych drogach twórczych nierzadko rzeczywistość przenika się z mistyfikacją. Małgorzata Stępnik wprowadza czytelnika w meandry rzeczywistego świata przeplatanego $\mathrm{z}$ fikcją, pozwalając poznać postaci prawdziwe, jak i te wymyślone dla „świata sztuki”. Niektóre z zaprezentowanych działalności twórczych nawiązują do różnych surrealizmów i awangard. Teoretycznym rozważaniom towarzyszy stała refleksja odwołująca się do klasycznych pojęć psychoanalizy i psychoanalitycznego myślenia o sztuce, w tym do pojęcia mechanizmów obronnych ego, ale także do takich pojęć kluczowych, jak: surrealizm, nadrealizm, maskarada, lustra, maski, sobowtóry, zmiana, transgresja, duchowa podróż, obcość, metamorfoza.

W pierwszym rozdziale książki autorka kreśli esej o micie Golema. Z tej figury korzysta wielokrotnie, uwypuklając jej uniwersalny charakter. Legenda o glinianym monstrum ożywianym słowem pojawia się jako dość stały rys odczytań różnorodnych prac (od komiksu po film). Dalej na układ treści książki składa się tekst o diasporycznym manifeście Ronalda B. Kitaja, o twórczych inkarnacjach Eleonor Antin, o lustrach i metaforach Eleonory Derenkowskiej (Maya Deren), o mistyfikacjach Roee Rosena, o twórczości surrealisty Edwarda Jamesa, o życiu i dziełach poetek Marii Komornickiej (czy też Piotra Własta) i Zuzanny Rabskiej, o sfalsyfikowanym wspomnieniu paryskim Piotra Szmitkego. Wszystkie małe historie są intymną narracją tworzącą art world. Opis postaci twórczych i strategii artystycznych, jakie stosują artyści i artystki jest wnikliwym i bardzo dokładnym spojrzeniem teoretyka sztuki, a także osoby działającej w sferze artystycznej praxis, co niesie ze sobą dodatkowy walor. 
Publikacja zasługuje na to, by wzbudzić zainteresowanie wśród akademików, zwłaszcza kulturoznawców, historyków, filozofów sztuki. Jestem przekonana, że sięgną po nią jednostki twórcze, ale i wychowawcy przyszłych artystów. Może ona stanowić pomocne kompendium wiedzy i źródło inspiracji dla dziedzin takich, jak psychologia i socjologia artystów. 


\section{Sprawozdanie z konferencji „Miłość w pedagogice - pedagogika w akcie twórczym"}

14 czerwca 2018 roku w Akademii Humanistyczno-Ekonomicznej w Łodzi, w Wydziale Zamiejscowym w Wodzisławiu Śląskim odbyła się konferencja naukowa pt. „Miłość w pedagogice - pedagogika w akcie twórczym”. Była to już IV edycja konferencji z cyklu „Rzeczywistość edukacyjna”. Konferencja została objęta patronatem honorowym przez prof. nadzw. dr hab. Joannę Satoła-Staśkowiak, rektor Akademii Humanistyczo-Ekonomicznej w Łodzi, jak również Towarzystwo Pedagogiki Filozoficznej im. B.F. Trentowskiego oraz czasopismo naukowe „Kultura i Wychowanie”. Konferencja zgromadziła niemal 40 uczonych z polskich, ale i z zagranicznych ośrodków akademickich. Celem konferencji była refleksja nad szeroko rozumianą wartością miłości w pedagogice.

Obrady konferencyjne zostały podzielona na trzy części. W części pierwszej, plenarnej głos zabrali: prof. zw. dr hab. Maria Szyszkowska z Uniwersytetu Warszawskiego - Nadużywanie pojęcia miłości, dr hab. Alina Rynio z Katolickiego Uniwersytetu Lubelskiego Jana Pawła II - Cechy i oblicza miłości w nauczaniu św. Jana Pawła II i Benedykta XVI, dr hab. Sławomir Sztobryn, prof. ATH z Akademii Techniczno-Humanistycznej w Bielsku-Białej - Miłość - między pragnieniem a tabu, dr hab. PhD. Andrej Rajsky, z Uniwersytetu w Trnavie na Słowacji - Love as Absolute Challenge Also for Education oraz prof. dr Yevhen Kulyk z Uniwersytetu w Połtawie na Ukrainie - Teachers of technology cultural training.

W pozostałych dwóch częściach uczestnicy konferencji podejmowali m.in. następujące tematy: dr Małgorzata Miksza, Uniwersytet Łódzki - Miłość jako wartość w pedagogice Marii Montessori, dr Magdalena Parzyszek, Katolicki Uniwersytet Lubelski Jana Pawła II - Od miłości oczarowania i rozczarowania do miłości dawania i otrzymywania, dr Teresa Jemczura, Państwowa Wyższa Szkoła Zawodowa w Raci- 
borzu - Miłość jako prymarna dystynkcja personalizmu pedagogicznego, dr Danuta Jurczyk, Akademia Humanistyczno-Ekonomiczna w Łodzi, Wydział Zamiejscowy w Wodzisławiu Śląskim - Miłość a resocjalizacja, dr Katarzyna Płoszaj, dr Wiesław Firek, Akademia Wychowania Fizycznego Józefa Piłsudskiego w Warszawie - Edukacja olimpijska Pierre’a de Coubertina - pomiędzy bierna tolerancją a miłościa aniołów, dr Andrzej Sztylka, Towarzystwo Pedagogiki Filozoficznej im. B.F. Trentowskiego - Humanistyczna idea miłości do tego, co ludzkie i jej pedagogiczne znaczenie, dr Norbert Niestolik, Akademia Humanistyczno-Ekonomiczna w Łodzi, Wydział Zamiejscowy w Wodzisławiu Śląskim - Irena Sendlerowa - miłość jako motyw działań człowieka, dr Ivan Podmanický, Trnava University in Trnava - Pedagogical Love and Prosociality in School Education of the Slovak Republic, s. mgr Adria M. Bach CSFN, Instytut Zarządzania Wiedzą Sp. z. o.o. Kraków - Wychowanie integralne, czyli o wartościach i miŁości (w imieniu s. mgr A.M. Bach głos zabrał dr J. Krysztofik), mgr Cecylia Mirela Nawrot, Ośrodek Doskonalenia i Kształcenia Ustawicznego PARTNER - Czas optymizmu w życiu małego dziecka, mgr Jowita Gromysz, Uniwersytet Wrocławski - Postromantycy - uczniowie XIX wieku, mgr Magdalena Szyszko, Ośrodek Edukacyjno-Leczniczy EGO, Jastrzębie-Zdrój - Triangulacja miłości jako potrzeba dyskursów wielokrotnych (w imieniu mgr M. Szyszko głos zabrał dr J. Krysztofik), mgr Adrianna Zawadzka, Akademia im. Jana Długosza w Częstochowie - Miłość jako inspiracja twórcza w pedagogice osób niepetnosprawnych, dr Krzysztof Kamiński, Akademia Humanistyczno-Ekonomiczna w Łodzi - Oligofilia (brak miłości) - jako zasadniczy deficyt wychowania.

Zderzenie wielości prezentowanych ujęć i stanowisk spotkało się z ożywionym zainteresowaniem prelekcjami, ale również skutkowało licznymi dyskusjami, które pewnie nie miałyby końca gdyby nie stanowczość moderatorów poszczególnych sekcji, którzy zostali poproszeni przez organizatorów o przestrzeganie ram czasowych. Dyskusje przenosiły się wówczas do kuluarów.

Spotykając się z licznymi słowami uznania, które spływały pod naszym adresem jako pomysłodawców i organizatorów konferencji, wracaliśmy do treści, które zostały zawarte w komunikacie konferencyjnym, a których wagę uznano na omawianej konferencji. W innym aspekcie treści te stały się asumptem do inicjowania nowych naukowych i praktycznych poszukiwań w obszarze zarysowanym tematyką konferencji. W komunikacie zawarliśmy przekonanie, że pedagogika o tyle ma sens, o ile wyraża się akcie twórczym. Zaznaczaliśmy, że mglistość terminu „twórczość” warunkowana była i jest m.in. bogactwem wielowiekowej tradycji, mnogością ujęć czy w końcu różnorodnością założeń teoretycznych i metodologicznych. Wspólnym mianownikiem wieloznacznego, pojemnego terminu „twórczość” staje się zaś każdorazowo kreatywna aktywność, co pozostaje w zgodzie z przekonaniem W. Okonia, który pojmował ją jako „proces działania ludzkiego dający nowe i oryginalne wytwory oceniane w danym czasie jako społecznie wartościowe”. Podkreślaliśmy, że mając na uwadze specyfikę dyscypliny, jaką jest pedagogika, należy przyjąć, że działalność twórcza odnosi 
się do najszlachetniejszego tworzywa, jakim jest człowiek, tworzywa, które domaga się urzeczywistnienia ze względu na dany cel. Przywoływana twórczość pedagogiczna miałaby na względzie określone „urzeczywistniania” w kontekście określonych idei. Największą z idei jest miłość, która domaga się praktycznych konkretyzacji, także kiedy poruszamy się w pedagogice. Wyłaniająca się tutaj, ale nienowa przecież w tradycji zachodniej, relacja potencji i aktu (z łac. actus - działanie) gwarantuje realizację lub zakończenie założonej zmiany, gwarantuje sukces, który pożądany jest również w RZECZYWISTOŚCI EDUKACYJNEJ. 


\author{
Adriana Modrzejewska, Julia Nowak, Radosław Pujanek \\ SWPS Uniwersytet Humanistyczno-Społeczny \\ Wydział Zamiejscowy w Katowicach
}

\title{
Aspekt wychowawczy kluczowych teorii psychologicznych w kontekście prewencji dziecięcych zachowań niepożądanych
}

\begin{abstract}
Streszczenie: Treść artykułu jest opisem wybranych teorii rozwoju człowieka i próbą przybliżenia koncepcji kryzysu jako zjawiska konstruktywnego lub destruktywnego w odniesieniu do rozwoju indywidualnego. Omówione w artykule są także stosowane metody wychowawcze z zakresu nauk humanistycznych. Powyższe zagadnienia zostały opisane w oparciu o teksty źródłowe z dziedziny psychologii rozwoju i pedagogiki. Przedstawione w tekście teorie są obecnie najczęściej prezentowane, ale nie wyczerpują listy wszystkich skonstruowanych do tej pory, jednakże autorzy zwracają szczególną uwagę na ich praktyczne zastosowanie w celu prawidłowego wsparcia rozwoju dziecka.
\end{abstract}

Słowa kluczowe: kryzys rozwojowy, rozwój, wychowanie, metody wychowawcze

\section{Wstęp}

Zachowanie oraz rozwój dziecka stało się przedmiotem badań naukowców już na przełomie XVII i XVIII wieku, wtedy, według Ariesa, pojawiła się pierwsza koncepcja dzieciństwa ${ }^{1}$. XVIII-wieczny poeta William Wordsworth mawiał „Ojcem Człowieka Dziecko Małe", co wskazuje na znaczenie tego okresu rozwojowego w perspektywie całego ludzkiego życia.

Tym samym od lat badacze dowodzą, jak ważnym momentem w życiu człowieka jest dzieciństwo, jak ogromny ma wpływ na dalsze funkcjonowanie jednostki pod każdym względem. Przez lata badań i obserwacji powstało kilka koncepcji. Wśród badaczy, którzy skupili się na okresie dzieciństwa pojawia się nazwisko G. Stanley Hall, który jako pierwszy został prezesem Amerykańskiego Towarzystwa Psychologicznego i w 1986 roku opublikował jedno z pierwszych badań nad dziećmi, w tym przypadku

\footnotetext{
${ }^{1}$ H.R. Shaffer, Psychologia dziecka, Wydawnictwo Naukowe PWN, Warszawa 2007, s. 41.
} 
nad jedynakami, które zatytułował „Dzieci osobliwe i wyjątkowe”. W swojej pracy sugerował, że „bycie jedynakiem jest chorobą samą w sobie” i postrzegał zachowania jako trwały objaw nieprzystosowania do środowiska. Następnie John B. Watson, zainspirowany poglądami Locke’a, który twierdził, że metodą wyjaśnienia ludzkiego zachowania są badania w kategoriach doświadczenia i uczenia się, użył po raz pierwszy terminu „behawioryzm” i spopularyzował go w środowisku psychologicznym. Rozpoczął on badania nad warunkowaniem strachu, gdzie obiektem badawczym był 11-miesięczny chłopiec, znany jako „Mały Albert”.

Piaget, szwajcarski uczony, jest uważany za naukowca, który miał ogromny wpływ na kształtowanie się poszczególnych zagadnień psychologii rozwojowej. Twierdził on, że dziecko na podstawie obserwacji i własnych doświadczeń uczy się środowiska. To nie środowisko kształtuje człowieka, lecz dziecko samo na podstawie własnych spostrzeżeń nadaje mu kształt. Ideę tę nazwał „konstruktywizmem”, dając tym samym do zrozumienia, że dziecko dąży do własnego sposobu konstruowania świata². Ponadto wprowadził termin „epistemologii genetycznej”, który mówi o badaniu zmian w wiedzy, następujących wraz z wiekiem dziecka. Piagetowskie podejście można ująć w stwierdzeniu, że aby zrozumieć, w jaki sposób dziecko przyswaja wiedzę, trzeba dokonać obserwacji, jak w trakcie rozwoju dziecko oddziałuje na środowisko i na odwrót ${ }^{3}$. Kolejnym naukowcem, który przysłużył się badaniom nad okresem dzieciństwa był Zygmunt Freud, twórca myśli psychoanalitycznej. Freud, opierając się na wspomnieniach z dzieciństwa swoich pacjentów oraz własnych, stworzył teorię rozwoju psychoseksualnego, składającego się z kilku etapów: fazy oralnej, analnej, fallicznej, fazy latencji oraz fazy genitalnej. Ważnym momentem w karierze naukowej Freuda było również wprowadzenie terminu nieświadomości. Badacz twierdził, że każde dziecko rodzi się z konkretnym zasobem energii seksualnej, którą nazwał „libido”. Dziecko kierując ową energię do stref erogennych, osiąga kolejne, wymienione już wcześniej etapy rozwoju psychoseksualnego ${ }^{4}$. Libido jest określane jako siła motywacyjna większości naszych zachowań i jest jednym z podstawowych, nieświadomych procesów używanych przez człowieka. Badania nad rozwojem skupiają się głównie na dwóch podstawowych aspektach: pierwszy z nich to analiza zachowań i zdolności w określonych momentach rozwoju, drugi bada dynamikę zachowania. $\mathrm{Na}$ ich podstawie naukowcy konstruują i rozwijają swoje teorie.

${ }^{2}$ H. Bee, Psychologia rozwoju człowieka, Wydawnictwo Zysk i S-ka, Poznań 2004.

${ }^{3}$ R. Vasta i in., Psychologia dziecka, Wydawnictwa Szkolne i Pedagogiczne, Warszawa 2004, s. 38-39.

4 Tamże. 


\section{Etapy rozwoju człowieka wg Eriksona}

$\mathrm{Na}$ szczególne wyróżnienie zasługuje związany z teorią psychoanalizy Erik H. Erikson, który wprowadził nową myśl, sugerującą, że rozwój człowieka wynika z wzajemnych oddziaływań pomiędzy instynktami wewnętrznymi a zewnętrznymi oraz kulturowymi i społecznymi oczekiwaniami ${ }^{5}$. Warto wspomnieć, że był on uczniem córki Zygmunta Freuda - Anny Freud i sporo czerpał z jego teorii. Następnie Erikson skonstruował teorię, która głosi, że rozwojowi człowieka towarzyszy w ciągu życia osiem kryzysów. Każdy z nich jest nowym wyzwaniem, trudnością charakteryzującą dany okres rozwojowy. Aby w pełni wykształcić swoją tożsamość, człowiek musi przejść przez owe kryzysy i pomyślnie je rozwiązać. Każdy moment kryzysu charakteryzuje się dwoma przeciwnościami, np. bliskość vs. izolacja. Erikson twierdzi, że aby doszło do rozwiązania kryzysu, jednostka musi doświadczyć jednego i drugiego aspektu oraz znaleźć równowagę między nimi ${ }^{6}$.

Jak już wspomniano, wyróżniono osiem kryzysów rozwojowych, każdy jest przypisany do określonego okresu w życiu człowieka. Pierwszy z nich przypada na pierwszy rok życia i określony został w kategoriach ufność vs. nieufność. Najważniejsze w tym okresie jest okazywanie dziecku czułości oraz trafne przewidywanie jego potrzeb. Kolejny przypada na okres wczesnego dzieciństwa - autonomia vs. wstyd, niepewność. Ważny aspekt w tym okresie to tzw. „trening czystości”. Dziecko w tym momencie ma szansę nauczyć się kontroli oraz pierwszego decydowania o sobie. Po tym okresie następuje wiek przedszkolny charakteryzujący się kryzysem inicjatywa vs. poczucie winy, w tym momencie rozwoju może dojść do konfliktu edypalnego z rodzicem, co może wzmagać poczucie winy, a tym samym dochodzi do zwiększenia poziomu asertywności. Następnie w wieku szkolnym dochodzi do kryzysu rozwojowego, gdzie pojawiają się kolejne dwa bieguny - pracowitość vs. poczucie niższości. Ten moment wiąże się z przystosowaniem i przyswojeniem sobie podstawowych umiejętności kulturowych oraz norm panujących w społeczności i środowisku rówieśniczym. Ponadto dziecko przyswaja umiejętności szkolne i uczy się korzystać z narzędzi. Kolejnym okresem kryzysowym jest wiek pokwitania, gdzie jednostka powinna znaleźć równowagę pomiędzy dwoma aspektami, które zostały sformułowane przez Eriksona jako tożsamość vs. pomieszanie tożsamości. W tym momencie następuje definiowanie własnego „ja”, własnej tożsamości. Człowiek określa swoje role w społeczeństwie, redefiniując dotychczasowe. Dokonuje wyboru pracy, osiąga tożsamość seksualną, a także eksploruje nowe wartości. W chwili, kiedy jednostka osiąga wiek dojrzały, przychodzi zmierzyć się jej z bliskością vs. izolacją. To jest moment, w którym zakłada się rodzinę, przemija miłość młodzieńcza, pojawia się dojrzałe uczucie. Zaraz po tym człowiek osiąga wiek średni, w którym napotyka dwa kolejne aspekty kryzysu - twórczość vs. stagnacja. Jednostka spełnia się w życiu zawodo-

\footnotetext{
${ }^{5}$ H. Bee, dz. cyt., s. 39.

6 Tamże.
} 
wym, stara się przekazywać wiedzę i doświadczenia kolejnym pokoleniom. W pewnym momencie człowiek decyduje się na rezygnację z samego siebie na rzecz innych. Ostatnim kryzysem, z jakim przychodzi się zmierzyć, jest okres starości, w którym pojawiają się dwa bieguny - integralność vs. rozpacz. Niewątpliwie wartość, jaką się zyskuje w tym okresie, to mądrość wypracowana na podstawie przeżytych doświadczeń. Człowiek jest świadomy własnego „ja”, osiąga pełną tożsamość, akceptuje siebie takiego, jakim jest ${ }^{7}$.

\section{Koncepcje psychologiczne a wychowanie}

Na przestrzeni lat oraz w toku prowadzenia badań nad rozwojem człowieka powstało wiele teorii odnoszących się do całościowego funkcjonowania jednostki zarówno w jej rozwoju indywidualnym, jak i przystosowaniu społecznym. Koncepcje rozwoju człowieka oraz metody wychowawcze są silnie zależne od przyjętego paradygmatu. Wśród najważniejszych wyróżnia się koncepcję behawiorystyczną, humanistyczną oraz psychospołeczną. Należy zaznaczyć, że każda z nich traktuje o prawidłowym rozwoju psychologicznym, a wszelkiego rodzaju nieprawidłowości mogą prowadzić do patologizacji poszczególnych aspektów życia w dorosłym życiu człowieka.

Głównymi założeniami koncepcji behawiorystycznej są uwarunkowania zewnętrzne, które mają szczególny wpływ na zachowanie (istota reaktywna). Istnieje podział koncepcji behawiorystycznej wychowania: wychowanie w skrajnej koncepcji behawiorystycznej i wychowanie w umiarkowanej koncepcji behawiorystycznej. Pierwsza z nich została stworzona przez Johna B. Watsona. Koncepcja ta jest przeciwwagą klasycznej psychologii introspekcyjnej. Według niego to, co przeżywa jednostka wewnątrz, nie wpływa w żadnym stopniu na zachowanie, a wręcz przeciwnie - zachowanie to odpowiedź na bodźce zewnętrzne. Wychowanie zatem jest oddziaływaniem wychowawcy na wychowanka. W konsekwencji tej teorii wychowanek może być pozbawiony prawa do własnej decyzji i może być traktowany przedmiotowo.

Wychowanie w umiarkowanej koncepcji behawiorystycznej (Carl Hovland, Robert Sears, John Dollard, Neal Miller, Hobart Mowrer, Joseph Wolpe, Albert Bandura) jest opisywane jako mniej skrajne w swoich założeniach. Autorzy zwrócili uwagę nie tylko na zmienne niezależne, jakimi jest otaczające środowisko, ale także zmienne pośredniczące lub niezależne - zakłócające. Warto też wspomnieć o warunkowaniu instrumentalnym, które gratyfikuje relacje pożądane oraz nagany i kary mające na celu zahamowanie zachowań niepożądanych ${ }^{8}$.

7 Tamże, s. 40.

${ }^{8}$ M. Łobocki M., Teoria wychowania w zarysie, Oficyna Wydawnicza Impuls, Kraków 2003, s. 59-63. 
Odmienną od koncepcji behawiorystycznej jest koncepcja humanistyczna, której czołowymi przedstawicielami są Abraham H. Maslow, Carl R. Rogers oraz Frederick S. Perls. Według niej jednostka jest samodzielna i nie ulega wpływom środowiska społecznego i fizycznego, a co za tym idzie, potrafi kierować swoim życiem i samodzielnie podejmować decyzje, za co odpowiedzialna jest wrodzona cecha człowieka - samoaktualizacja (self-actualization). W myśl tej koncepcji człowiek skupia się na własnym „ja”, które pomaga mu w dalszym rozwoju, nie angażując w to świata zewnętrznego. Wychowanie zgodnie z założeniami koncepcji humanistycznej ma na celu stworzenie warunków do samorealizacji wychowanka, wyklucza narzucanie czegokolwiek pod przymusem, a więc stawia na naturalny rozwój jednostki.

Inne założenie od powyższych koncepcji nakreśla koncepcja psychospołeczna. Jej pionierami są Alfred Adler, Erich Fromm, Karen Horney i Harry S. Sullivan. Ważnym czynnikiem w rozwoju i wychowaniu są stosunki interpersonalne w środowisku jednostki. Według H.S. Sullivana charakter interpersonalny mają: spostrzeganie, myślenie, zapamiętywanie i marzenia senne. Zachowania jednostki są zatem wytworem stosunków interpersonalnych. Nawiązując do tego stwierdzenia, E. Fromm zwraca uwagę na brak kontaktów interpersonalnych i uważa, że skutkuje to samotnością i wyobcowaniem, co jest dla jednostki destrukcyjne. Na proces wychowania mogą również wpływać warunki życia społecznego, w jakich żyją dzieci, młodzież i dorośli9.

\section{Kryzys jako czynnik determinujący rozwój człowieka}

W życiu człowieka kryzys można rozpoznać jako zjawisko rozwojowe lub niemające charakteru rozwojowego, co w obu przypadkach wpływa na jednostkę i determinuje jej zachowanie oraz społeczne funkcjonowanie na kolejnych etapach rozwoju. Kryzys o charakterze nierozwojowym najczęściej jest definiowany jako specyficzna reakcja na określone zdarzenie, które zagraża życiu lub zdrowiu człowieka, lub jego najbliższym. Rozróżnienie kryzysów zaproponował Klaus Riegel w swojej dialektycznej koncepcji rozwoju. Oba rodzaje kryzysu są wynikiem asynchronii między czterema sekwencjami zdarzeń: wewnętrzno-biologiczną, indywidualno-psychologiczną, kulturowo-społeczną i zewnętrzno-fizyczną ${ }^{10}$. Występowanie asynchronii między powyższymi płaszczyznami jest właśnie przyczyną kryzysów. Niezgodność między wewnątrzbiologicznym rozwojem a psychicznym rozwojem indywidualnym opisane jest jako przyczyna kryzysu rozwojowego człowieka. Natomiast zmiany środowiskowe (fizyczne i zewnętrzne - niezależne od jednostki), które są niezgodne z postępem kulturowo-społecznym, Riegel opisuje jako katastrofy, które w konsekwencji nie mu-

9 Tamże, s. 64-74.

${ }^{10}$ M. Przetacznik-Gierowska, M. Tyszkowa M., Psychologia rozwoju człowieka. Zagadnienia ogólne, Wydawnictwo Naukowe PWN, Warszawa 2007, s. 80-82. 
szą mieć znamion patologicznych ${ }^{11}$. Rozpoznanie poszczególnych rozbieżności daje możliwość podjęciu działań prewencyjnych, co w sprzyjających warunkach pomaga w korygowaniu elementów wpływających na powstanie asynchronii. Ujęcie kryzysu w taki sposób nadaje mu znaczenia konstruktywnego i nadaje sens zmianom wstępującym w obrębie jednostki.

W procesie życia człowieka oraz na drodze empirii można wyodrębnić poszczególne etapy rozwoju, na które składają się określone i charakterystyczne zadania życiowe. Robert Havighurst w swojej koncepcji opisuje rozwój psychiczny jako proces wypełniania poszczególnych zadań, a ich realizacja może mieć mniej lub bardziej świadomy charakter. Havighurst wyróżnił szereg zadań rozwojowych, które muszą zostać spełnione, przechodząc od jednego stadium do następnego, co wpływa na prawidłowy rozwój jednostki. Według definicji autora zadanie rozwojowe (developmental task), to zadanie wyłaniające się w określonym momencie życia, a jego pomyślne rozwiązanie predestynuje dziecko i osoby dorosłe do efektywnego wykonania późniejszych zadań. Z drugiej strony, niepowodzenie może być powodem występowania trudności w późniejszych etapach oraz przyczyniać się do gorszego funkcjonowania człowieka w społeczeństwie ${ }^{12}$.

\section{Metody wychowania}

Stosowanie właściwych metod wychowawczych może pomagać w zachowaniach prewencyjnych dotyczących kryzysów rozwojowych. Takie metody są stymulatorami zachowań, które mają za zadanie doprowadzić jednostkę do osiągnięcia wcześniej wyznaczonego celu wychowawczego. W zakresie nauk humanistycznych wyodrębnić można następujące metody wychowania:

- metoda modelowania

- metoda zadaniowa

- metoda perswazyjna

- metoda nagradzania

- metoda karania.

Metoda modelowania jest uznawana za jedną z najbardziej skutecznych. Charakteryzuje się nieświadomym przyswajaniem zachowań i postaw innych osób, a najczęściej takich, z którymi jednostka jest w bliskim kontakcie. Badania psychologiczne udowodniły, że osobami ze skłonnościami przyswajania zachowań są w szczególności dzieci. Zatem metoda modelowania to metoda dawania dobrego przykładu. Ważną kwestią jest, żeby zachowywać się przykładnie nie tylko w stosunku do wychowanka, ale także do innych osób. Wskazano czynniki, które wywierają większy wpływ na obserwatora. Należą do nich między innymi postrzeganie swoich kompetencji, dzięki

\footnotetext{
11 Tamże, s. 67-68.

12 Tamże, s. 67.
} 
którym obserwator cieszy się prestiżem w swoim otoczeniu; szeroki zakres władzy wychowawcy, dzięki której może wesprzeć wychowanka w sferze duchowej i materialnej; widoczne podobieństwa do wychowawcy w zakresie kompetencji i zainteresowań; entuzjazm dla zachowań altruistycznych.

Metoda zadaniowa polega na powierzaniu jednostce zadania, które ma doprowadzić do konkretnego celu wychowawczego. Powierzanie takich zadań może mieć miejsce w rodzinie, w szkole, jak i poza nimi. Ważnymi elementami w tej metodzie są świadoma chęć i zainteresowanie, znajomość celu, zadanie na miarę możliwości jednostki, stopniowe zadania - od łatwych, po złożone, pochwały za wykonane zadanie.

Metoda perswazyjna, inaczej nazywana metodą perswazji, ma na celu uświadomienie dzieciom i młodzieży ich praw, obowiązków i powinności wobec siebie, jak i wobec innych; oddziałuje więc na świadomość moralną i społeczną, a także kształtuje system wartości moralnych.

Metoda nagradzania, to tzw. wzmacnianie pozytywne, czyli gratyfikuje zachowania pożądane nagrodami lub pochwałami. Metoda ta jest skuteczna wtedy, kiedy dana gratyfikacja jest pożądana przez dziecko. Nagradzanie pełni dwie funkcje: dzieci i młodzież uczą się wykonywać poprawnie zadania, które otrzymali od dorosłych oraz gratyfikacje wpływają na ich motywację.

Metoda karania jest najbardziej znaną i najczęściej stosowaną ze wszystkich metod. Polega na stosowaniu kar w celu zapobiegania zachowaniom niepożądanym. Metoda ta może obejmować takie zachowania, jak: „wyrażanie formalnej dezaprobaty $\mathrm{w}$ formie upomnienia lub nagany, wykluczenie $\mathrm{z}$ udziału w zabawie czy w innych formach życia zbiorowego, zawężanie marginesu swobód, w tym także ograniczenie lub pozbawienie uprawnień, przywilejów, funkcji, albo odebranie jakiejś rzeczy pożytecznej czy przyjemnej"13. Wiele osób wiąże tę metodę z negatywnym napięciem psychicznym u dzieci i młodzieży, co prowadzi do zachowań agresywnych ${ }^{14}$.

Połączenie psychologicznych koncepcji związanych z kryzysem rozwojowym z pedagogicznymi koncepcjami wychowania i stosowanymi metodami wychowawczymi stanowi dopełnienie mające zasadnicze znaczenie dla prawidłowego rozwoju dziecka.

\section{Podsumowanie}

Rozwój człowieka to zjawisko trudne do zbadania ze względu na wielość czynników ulegających zmianie oraz niedostateczną liczbę obiektywnych narzędzi badawczych. W zakresie nauk humanistycznych pewne koncepcje, które próbowaliśmy przybliżyć, powstały na drodze obserwacji człowieka, na przestrzeni lat i zmian, jakie w nim zachodziły oraz przyjmowania określonego paradygmatu. Można więc zało-

\footnotetext{
${ }^{13}$ M. Łobocki M., dz. cyt., s. 204-205.

${ }^{14}$ Tamże, s. 182-208.
} 
żyć, że na prawidłowy rozwój jednostki składają się czynniki intrapsychiczne, biologiczne, środowiskowe, kulturowe i społeczne. Wsparcie rozwoju ze strony rodziny i najbliższego środowiska na poszczególnych etapach życia często jest silnie zależne od przyjętych metod wychowawczych. Badania z zakresu psychologii rozwojowej i pedagogiki mają ogromne znaczenie dla prowadzenia prewencji i korygowania zachowań niepożądanych lub społecznie nieakceptowanych, co może mieć znaczący wpływ na funkcjonowanie jednostki w życiu dorosłym.

\section{Bibliografia}

Bee H., Psychologia rozwoju człowieka, Wydawnictwo Zysk i S-ka, Poznań 2004.

Łobocki M., Teoria wychowania w zarysie, Oficyna Wydawnicza Impuls, Kraków 2003.

Przetacznik-Gierowska M., Tyszkowa M., Psychologia rozwoju człowieka. Zagadnienia ogólne, Wydawnictwo Naukowe PWN, Warszawa 2007.

Shaffer H.R., Psychologia dziecka, Wydawnictwo Naukowe PWN, Warszawa 2007. Vasta R. i in., Psychologia dziecka, Wydawnictwa Szkolne i Pedagogiczne, Warszawa 2004.

\section{Educational aspect of the key psychological theories in relation to prevention of child adverse behaviour}

Abstract: This article describes selected theories of human development and juxtaposes the concept of crisis as a constructive and deconstructive phenomenon with the notion of personal development. The article reviews educational methods used in humanities. The article engages with literature from developmental psychology and pedagogy. Many of the presented theories are widely known, but other, less well-known theories are also discussed. The authors of this article focus on the practical function of such theories in order to support child development.

Keywords: development crisis, development, upbringing, educational methods 
Obszar zainteresowań czasopisma naukowego „Kultura i Wychowanie” z założenia ma szeroki zakres. Odwołuje się do zagadnień związanych z interdyscyplinarną relacją kultury i wychowania.

Prezentowane wyniki badań naukowych, głównie z obszaru pedagogiki, ujmowane są w dwa bloki tematyczne rozpraw: filozoficzno-historyczne oraz teoretyczno-empiryczne.

Wersja internetowa, będąca podstawową formą publikacji, dostępna pozostaje na stronie: www.pedagogika.pl

Zespół redakcyjny 